\title{
Desenho de letras em livros das Reduções Jesuíticas Guarani
}

Kollontai Cossich Diniz

São Paulo, 2014 
Dissertação de mestrado

Desenho de letras em livros das Reduções Jesuíticas Guarani

Kollontai Cossich Diniz

Prof. Dra. Priscila Lena Farias - orientadora

Dissertação de mestrado apresentada à Faculdade de Arquitetura e Urbanismo da Universidade de São Paulo como requisito parcial para a obtenção do título de Mestre em Arquitetura e Urbanismo.

Área de concentração: Design e arquitetura Linha de pesquisa: Linguagem e projeto 
Autorizo a reprodução e divulgação total ou parcial deste trabalho, por qualquer meio convencional ou eletrônico, para fins de estudo e pesquisa, desde que citada a fonte.

E-mail da autora: tai@usp.br

DINIZ, Kollontai Cossich

Desenho de letras em livros das Reduções Jesuíticas Guarani

Dissertação de mestrado apresentada à Faculdade de Arquitetura e Urbanismo da Universidade de São Paulo como requisito parcial para a obtenção do título de Mestre

Data:

Catalogação da Publicação

Serviço de Documentação da Faculdade de Arquitetura e Urbanismo

da Universidade de São Paulo

Diniz, Kollontai Cossich

(ivros das Reduções

Jesuíticas Guarani / Kollontai Cossich Diniz. -- São Paulo, 2014.

175 p. : il.

Dissertação (Mestrado-Área de Concentração: Designe Arquitetura)-FAUUSP. Orientadora: Priscila Lena Farias

1.Tipografia 2.Guarani 3.Jesuítas 4.Missões religiosas -

Rio da Prata 5.Obras raras 6.Companhia de Jesus - Rio da Prata

CDU 76 em Arquitetura e Urbanismo.

\section{Banca examinadora:}

Julgamento:

Profa. Dra. Priscila Lena Farias - orientadora

Universidade de São Paulo

Julgamento:

Nome:

Instituição:

Julgamento:

Nome:

Instituição:

Julgamento:

Nome (suplente):

Instituição:

Nome (suplente):

Instituição: 


\section{AGRADECIMENTOS}

Priscila Farias orientou meus estudos de mestrado e não mediu esforços para viabilizar o que foi necessário para a escrita desta dissertação. Agradeço por sua total disponibilidade para encontros de orientação, pela revisão rigorosa a cada versão enviada do texto, pela atenção aos prazos e trâmites burocráticos que fazem parte do percurso acadêmico e, acima de tudo, agradeço a confiança.

Anna Paula Silva Gouveia orientou meus estudos antes ainda, agradeço seus comentários a textos que viraram, depois, o projeto de pesquisa que submeti para ingresso no programa de pós-graduação da FAU e as referências bibliográficas que compartilhou comigo.

Catherine Dixon, professora visitante da FAU em 2011, fez muitos comentários aos primeiros escritos decorrentes da pesquisa e também compartilhou valiosas referências bibliográficas. Agradeço o cuidado despendido e a precisão de suas críticas.

Isabella Aragão fez sugestões preciosas ao artigo "Tudo sua pena desenha", que foram incorporadas a esta dissertação. Agradeço por sua gentileza em ler e comentar o artigo e extendo o agradecimento aos colegas do grupo de orientandos e orientandas da Priscila por acompanharem a gestação deste texto.

Pedro Puntoni e Marisa Midori Deaecto estiveram na banca de qualificação do mestrado, em março de 2013. Agradeço pela leitura atenciosa do memorial de qualificação e valiosos comentários à pesquisa.

Novamente ao Pedro Puntoni, e também às amigas Miriã Gomes do Nascimento, Carla Piazzi, Ágatha Francesconi Gatti e aos demais colegas da Brasiliana USP, agradeço pelo empenho e confiança na ampliação do acesso a acervos de obras raras por meio da digitalização. Sem a digitalização dos guaraníticos da Biblioteca Brasiliana Guita e Mindlin e da John Carter Brown Library esta pesquisa não teria acontecido.

Laura Mello Alves Pires me auxiliou recortando as infindáveis letrinhas dos impressos guaraníticos, o que apelidou de "caça letras". Sou muito grata pelo entusiasmo e bom humor com que levou este trabalho aparentemente enfadonho. 
Sou grata também à Cristina Antunes, por abrir a Biblioteca Mindlin, ainda no Brooklin, para consulta dos originais guaraníticos.

Fernanda Veríssimo compartilhou comigo sua tese de doutorado, não publicada, sobre os livros rio-platenses, uma referência sem a qual este trabalho ficaria incompleto, ela também fez indicações de outras referências valiosas para esta dissertação. Sou muito grata por sua imensa generosidade.

Agradeço a todos os funcionários e funcionárias da FAU Maranhão, em especial: Maria José, bibliotecária, pela elaboração da ficha catalográfica; e Isa, Regina e Diná, pela seriedade e bom humor implacável com que acolheram minhas inúmeras dúvidas sobre as normas e burocracias da pós.

\section{À Fapesp, Fundação de Amparo à pesquisa do Estado de São Paulo, agradeço pelo auxílio} financeiro.

Agradeço ainda: à Ana Paula Pires da Silva e à Miriam Dascal, pelo trabalho com a escuta, com a fala e outros fenômenos do corpo, o que certamente amenizou angustias neste caminho que trilhamos pelo desejo de saber. Às jardineiras da Tucuna, Sarah Elizabeth e Raphaëlle Faure-Vincent minha sincera gratidão por sua amizade e carinho nestes anos desde o início do mestrado, e ao jardineiro Fernão Lopes Ginez de Lara também agradeço, claro, por tudo. À grande amiga Laura Furquim e ao Guilherme Mongeló, do Museu de Arqueologia e Etnologia da USP, agradeço por me iniciarem no "encontro de gestos", me mostrando que o que faço é, um pouco, arqueologia. À Kena Chavez, Tatiana Burg e Felipe Guimarães agradeço os cuidados durante os tempos turbulentos da qualificação. Flamarion Borges Diniz, Rachel Cossich Furtado, Barbara Cossich Diniz e Elyeser Szturm incentivam e entusiasmam-se com meus estudos desde sempre, sou muito grata a eles e a elas também.

Não é simples terminar um mestrado em 2013, o ano das jornadas de junho. O ímpeto é mais pela ruptura do que pela continuidade. Agradeço a todas as pessoas que, entre estudos, emprego e trabalho doméstico, se desdobram pela novidade no mundo.
RESUMO — Desenho de letras em livros das Reduções Jesuíticas Guarani.

Nesta dissertação examino o desenho das letras em livros produzidos nas Reduções Jesuíticas Guarani, empreendimento missionário de religiosos da Companhia de Jesus na região do Rio da Prata entre 1609 e 1768. Os primeiros Jesuítas chegaram à região em 1585, vindos do Peru e do Brasil. Apesar das dificuldades dos primeiros tempos, fundaram a primeira Redução em 1609 e, tão logo conquistaram alguma estabilidade, comunicaram-se intensamente com Roma e Madrid, entre 1633 e 1645, a fim de obterem uma imprensa e licenças para imprimir nas Reduções. Porém, foi apenas entre 1700 e 1705 que finalmente o realizaram - e não foi por meio de uma prensa vinda da Europa, mas de prensa construída nas missões. Antes disso, os livros eram copiados à mão, uma prática que continuou existindo nas Reduções mesmo depois da instalação da imprensa. À imprenta guaranítica e aos manuscritos guaraníticos cabe um lugar de destaque na História da imprensa e do livro no Novo Mundo. Os relatos dos padres geraram consensos ainda hoje repetidos na historiografia da região, especializada ou não na História dos livros, sobre a habilidade dos guaranis para copiar letras e sobre a construção de todo o aparato para impressão - a prensa tipográfica construída com madeira local e tipos móveis fundidos com uma liga de metais da região. Dos doze livros e um tanto de panfletos que certamente foram impressos nas Reduções, é possível localizar hoje exemplares de oito títulos apenas. Analisei o desenho das letras na folha de rosto e no miolo de seis títulos impressos e em três títulos manuscritos. As análises do desenho das letras nestes livros levaram-me a indagar se de fato fundiu-se tipos nas missões (resultado das análises das letras impressas) e a apontar a variedade de desenho de letras manuscritas ao invés da duplicação de modelos europeus (resultado das análise das letras manuscritas). Os resultados são uma contribuição à historiografia que busca questionar o uso da documentação textual como principal forma de testemunho da empresa missionária e, sobretudo, que busca questionar o ponto de vista de onde a história da produção livreira e da escrita nas Reduções Jesuíticas Guarani tem sido contada. Um ponto de vista que serve mais à manutenção da "rareza" dos livros guaraníticos do que ao esforço pela sua compreensão.

Palavras-chave: Tipografia; Guarani; Jesuítas; Missões Religiosas; Rio da Prata; Obras raras. 
ABSTRACT — Letterforms on books from the Guarani-Jesuit Reductions.

In this dissertation I examine the letterforms on books from the Guarani-Jesuit Reductions, a missionary enterprise of the religious fathers of the Jesus Company, in the River Plate area from 1609 to 1768 . The first jesuits arrived in the region in 1585, coming from Peru and Brazil, and despite the difficulties of the early years, they settled the first Reduction in 1609. As soon as they conquered some stability, they communicated intensely with Rome and Madrid, from 1633 to 1645 , supplicating for a printing press and the necessary licenses to print in the Reductions. Notwithstanding, it was only around 1700 that they finally achieved their intentions - and it was not by means of a printing press brought from Europe, but of a printing press built in the missions itself. Before this, books were copied by hand, a craft that continued after the establishment of the printing press. The guarani prints and the guarani manuscripts have a distinguished place in the History of the book and printing in the New World. Reports written by the jesuit fathers from the Reductions generated some consensus that are repeated still today in the historiography of the region, specialised or not in book and printing, about the guaranis' great ability to copy letters by hand and about the construction of the whole apparatus necessary for printing - a printing press built with local wood and sorts cast with a metal league from the region. Of the dozen books and some pamphlets that were certainly printed in the Reductions, today it is possible to find copies of only eight titles. I analysed the letterforms in six of these books and in three manuscripts. The analysis made me question if type was really cast in the missions (result of analysing the printed books) and made me point out the variety of manuscript letterforms instead of the duplication of european models (result of analysing the manuscript books). The results are a contribution to the historiography that questions the use of textual documentation as the main source of testimonies about the missionary enterprise, and, above all, the historiography that questions the point of view from which the history of book production and the history of writing in the Guarani-Jesuit Reductions have been told. A point of view that promotes the "rarity" of the guarani books instead of the effort for its understanding.

Keywords: Typography; Guarani; Jesuits; Religious Missions; River Plate; Rare books. 
LISTA DE FORMAS ABREVIADAS

Catecismo impresso

Catecismo manuscrito

Ordo

Edvcacion

Instruccion

Manuale

Vocabulario

Arte

Explicacion

Sermones
Catecismo de la lengua guarani [...]. (MONTOYA, 1640) Catecismo de la lengua guarani [...]. (MONTOYA, 16--) Ordo baptismi parvulorum [...]. (ANôNimo. 16--)

Edvcacion christiana: y buena criança [...]. (ANÔNIMO. 1713)

Instruccion practica para ordenar santamente la vida [...]. (GARRIGA, 1713) Manuale ad usum patrum [...]. (ANÔNIMO, 1721)

Vocabulario de la lengua guarani [...]. (RESTIVo, 1722)

Arte de la lengua guarani [...]. (REsTIvo, 1724)

Explicacion de el catechismo en lengua guarani [...]. (YAPUGUAI, 1724)

Sermones y exemplos en lengua guarani [...]. (YAPUGUAI, 1727) 


\section{SUMÁRIO}

INTRODUÇÃO

I. GUARANIS E ESCRITA NA BACIA DO PRATA

1.1. Os antigos guaranis - dois mil anos até a Bacia do Prata

1.2. Jesuítas com a fscrita - dois mil anos até a Bacia do Prata

II. O DESENHO DAS LETRAS RIO-PLATENSES

2.1. O DESENHO DAS LETRAS MANUSCRITAS

2.1.1. O modelo e a cópia: Catecismo de la lengua guarani [...]. 1640

2.1.2. Manuscrito sem modelo: Edvcacion christiana [...]. 1713

2.1.3. As belas letras do Ordo baptismi parvulorum. [...]. 16--

2.2. O DESENHO DAS LETRAS IMPRESSAS

2.2.1. Letras impressas em Loreto

Instruccion practica para ordenar santamente la vida [...]. 1713 Manuale ad usum patrum [..].1721

2.2.2. Letras impressas em Santa Maria la Mayor Vocabulario de la lengua guarani [...]. 1722 Arte de la lengua guarani [...]. 1724 Explicacion de el catechismo en lengua guarani [...]. 1724

2.2.3. Letras impressas em São Francisco Xavier

Sermones y exemplos em lengua guarani [...]. 1727

III. A INCONSTÂNCIA DAS LETRAS RIO-PLATENSES

1. INCONSTÂNCIA NAS LETRAS MANUSCRITAS

3.2. INCONSTÂNCIA NAS LETRAS IMPRESSAS

IV. CONSIDERAÇÕES FINAIS

FONTES PRIMÁRIAS

REFERÊNCIAS BIBLIOGRÁFICAS 


\section{INTRODUÇÃO}

Esta dissertação situa-se no campo da História do Livro e da Tipografia nas Reduções de Guaranis. As Reduções de Guaranis foram um empreendimento missionário de religiosos da Companhia de Jesus que durou de 1609 a 1768, na Bacia do Rio da Prata, compreendida entre os atuais territórios do Paraguai, Argentina, Bolívia, Uruguai e Brasil. A atenção principal volta-se para o desenho de letras impressas e manuscritas nas missões, buscando responder à seguinte pergunta fundamental de pesquisa: O que a análise do desenho de letras em livros produzidos nas Reduções Jesuíticas Guaranis dá a saber a respeito da imprenta guaranítica - frequente exaltada nos relatos de jesuitas por empregar tipos fundidos nas missões - e a respeito dos manuscritos guaraníticos - frequentemente aclamados como prova da habilidade dos guaranis para copiar com perfeição?

\section{Introdução ao estudo}

Os primeiros religiosos da Companhia de Jesus chegaram à bacia do Rio da Prata em 1585. Apesar das dificuldades dos primeiros tempos, fundaram a primeira Redução em 1609 e, tão logo conquistaram alguma estabilidade, comunicaram-se intensamente com Roma e Madrid, entre 1633 e 1645, a fim de obterem "un hermano impresor, la imprenta y las reales licencias para usarla” (FURLONG, 1953a:47).

Nestes anos foram muitas as postulações para imprimir nas missões. Os padres pediam "insistentemente uma imprensa para assim publicar gramáticas e sermões em vários idiomas indígenas, assinalando que isto era sumamente necessário" (АСТA CONGREGATIONIS apud FURLONG, 1953a:46 - tradução minha'). Suplicavam que viesse das Provincias de França, Alemanha e Flandres algum irmão que entenda disso para que, comprando uma imprensa, se possa conseguir este efeito de tanta importância para o bem das almas (ACTA CONGREGATIONIS apud FURLONG, 1953a:46 - tradução minhaª).

1 "Insistentemente pide una Imprenta para publicar asi gramaticas como sermones em vários idiomas indigenas, sumamente necesario." (ACTA CONGREGATIONIS apud FURLONG,1953a:46)

2 "Nos mande dar de las Provincias de Francia o de Alemania y Flandes algún hermano que entienda de eso para que, comprando una imprenta, se pueda conseguir este efecto de tanta importância para el bien de las almas." (ACTA CONGREGATIONIS apud URLONG, 1953a:46) 
Laboriosos empreendedores da renovação católica, os padres da Companhia de Jesus têm com a tipografia uma relação primordial, que não é específica das Reduções Rio-platenses. Na Europa do Século XVI, quando da criação da Ordem, a impressão para a difusão de idéias religiosas está a todo vapor - impressos protestante em línguas vernáculas, se popularizam e impulsionam a Reforma, numa Europa onde poucos lêem latim, abrem uma janela para o mundo não apenas para a minoria letrada, mas também para quem ouvia a sua leitura em voz alta. No seio da Contra Reforma, os jesuítas perceberam a dimensão da imprensa como difusora da fé e passaram a imprimir obras apologéticas e polêmicas a favor da igreja católica (O'MALLEY, 2004:232), se tornando grandes clientes de renomadas editoras, como Moretus, na Antuérpia (FeBVRE E MARTIN, 1992[1958]:276-278).

Nos empreendimentos jesuíticos na Ásia a imprensa também está presente, desde cedo. Em Goa começam a operar uma oficina tipográfica em 1556, onde imprimem livros em português, tâmil e latim (ÜÇELER, 2008:155); e na América do Sul não é diferente: aos jesuítas se deve a primeira imprensa deste continente, em Lima - la ciudad de los Reyes -, onde imprimiram pela primeira vez em 1584 (FURLONG, 1984[1933]:143).

A segunda oficina tipográfica sul-americana foi a das Reduções Guaraníticas, tão esperada pelos padres desde os primeiros pedidos em 1630. Não obstante as súplicas no período inicial das Reduções, foi apenas entre 1700 e $1705^{3}$ que finalmente os jesuítas lograram imprimir livros no Prata. E não foi por meio de uma prensa vinda da Europa, mas de prensa construída nas missões mesmo. A Juan Baptista Neumann, austríaco, e Serrano, espanhol, é atribuída a criação da prensa tipográfica missioneira, a qual Furlong se refere como "um dos feitos históricos mais impressionantes por sua audácia, e dos mais belos, por sua espontaneidade e naturalidade, de que há notícia nos anais da cultura americana" (FURLONG, 1953a:57 - tradução minha ${ }^{4}$.

Se para Furlong a criação da prensa é efeito do gênio humano, seu próprio criador, o Padre Serrano, atribui a deus tão admirável obra. Assim escreve ao superior geral da Companhia de Jesus:

Declaro ao Divino Senhor haver logrado o desejo de V. P. se imprimam estas obras nas Reduções, sem gastos, assim de execução, com os caracteres desta língua e advindos da Europa; pois assim a impressão, como as muitas lâminas para seu realce, são obra do dedo de Deus, tanto mais admiráveis, quanto os instrumentos são uns pobres índios, novos na

3 Dentre os exemplares da imprenta guaranítica que ainda hoje podem ser localizados, o mais antigo é o livro De la Diferencia
entre lo Temporal ylo Eterno [...], impresso em 1705. Entretanto, Josefina Pla (1975:254) inclui em sua lista o livro Martirolo entre lo Temporal y lo Eterno [...., impresso em 1705. Entretanto, Josefina Pla (1975:254) inclui em sua lista o livro Martirologio Romano, que teria sido impresso cinco anos antes, em 1700.

4 "La labor de los mismos [Neumann e Serrano] es uno de los hechos históricos más impresionantes por su audacia, y de los más bellos, por su espontaneidad y naturalidad, de que hay noticia en los anales de la cultura americana." (FURLONG, 1953a:57) fé e sem a direção de professores da Europa, para que conste que tudo é favor do céu, que quis por meio tão inopinado ensinar a estes pobres a verdade da Fé.

(SERRANO apud FURLONG, 1953a:68 - tradução minha ${ }^{5}$ )

A dimensão sublime da imprenta guaranítica ecoa no que se escreve ainda hoje sobre os livros produzidos nas Reduções. Para Johnson (1988) as Reduções Guaraníticas são "a estória mais dramática da evangelização no Novo Mundo" (1988:73) ao que segue que os livros impressos ali são "extremamente raros" (1988:75), já Woodbridge e Thompson descrevem a imprenta guaranítica como um "conto extraordinário da história da imprensa" (wOOdbridge e thompson, 1976:52). Por um lado, estes livros são raros pois poucos exemplares chegaram aos dias de hoje - dos doze livros e um tanto de panfletos que certamente foram impressos nas missões guaraníticas rio-platenses, é possível localizar exemplares de oito títulos apenas ${ }^{6}$ e a quantidade de exemplares restantes por título é também pequena. Por outro lado, a indicação de raridade dos impressos guaraníticos não se dá apenas pela sua pequena quantidade, mas também pelas clamorosas narrativas sobre a construção da prensa e dos tipos móveis necessários para sua operação, usando "materiais e trabalho nativos sempre que possível, em todas as fases do processo de impressão, sendo apenas o papel importado da Espanha" (JOHNSON, 1988:75 - tradução minha7).

A instalação de uma tipografia e impressão de livros nos confins da Bacia do Prata ao início do Século XVIII é, sem dúvidas, um feito notável. Entretanto, as narrativas que ainda hoje se repetem na historiografia do livro nas Américas sobre este extraordinário conto podem ter raízes também nas fábulas em que estava envolta a articulação entre descoberta e imprensa. Em $O$ aparecimento do livro, Febvre e Martin (1992[1958]), sempre preocupados com a mentalidade dos conquistadores, atentam para os efeitos que romances de cavalaria publicados à época do descobrimento por Cromberger, de Sevilha, - o mesmo que enviaria material a Juan Pablo primeiro impressor das Américas (Cf. GRAÑÉN PORRÚA, 2010) - teria nas ganas dos espanhóis por terras longínquas e opulentas,

Não é por acaso que a era dos conquistadores foi também aquela em que o livreiro Cromberger, de Sevilha, publicava seu Sergas de Esplandián, o segundo romance de Montalvo, seqüência do Amadis de Gaula, no qual se trata precisamente do povo das

5 "Retorno al Divino Señor el haber logrado el deseo de V. P. se impriman estas obras en las Doctrinas ["Doctrinas" são as Reduções], sin gastos, así de la ejecución, como en los caracteres própios de esta lengua y peregrinos de la Europa; pues así la son unos pobres indios nuevos en la fe y sin l dirección de los maestro de la Euro ta para que conste que todo es favor del cielos que quiso por medio tan inopinado enseñar a estos pobres las verdades de la Fe." (SERRANO apud FURLONG:1953a:68)

6 A localização atual dos exemplares de cada um dos títulos segundo foi Fernanda Veríssimo (2011) pode ser consultada em aneXo (ANEXO 1).

"Native materials and labor were utilized as much as possible in al phases of the printing process, and only paper was imported from Spain." (JонNson, 1988:75) 
Amazonas vivendo na Ilha de Califórnia; também não é por acaso que esse romance foi reeditado sem cessar enquanto Cortez conseguia conquistar e submeter vastos reinos do México, enquanto Pizarro, depois Almagro se lançavam na bacia das Amazonas, de nome sintomático, à procura do Eldorado.

\section{(FEBVRE e MARTIN, 1992[1958]:302)}

Alguns anos antes da publicação da obra de Febvre e Martin, Lugon apontava que a própria origem das Reduções Guaraníticas deve "à atmosfera de legenda dourada em que as mergulharam as narrativas e relatos do século XVII" (LUGON, 1977[1949]:27). De fato, cada passo da descoberta do Novo Mundo foi "muito articulada, mediada e promovida pela palavra impressa" (MARTIN III, 2007:259 - tradução minha ${ }^{8}$ ).

O esforço que fiz na pesquisa que dá corpo a esta dissertação, foi o de descolar-me ao máximo das envolventes narrativas que circundam a produção livreira guaranítica nos relatos dos jesuítas sobre as missões e voltar minha atenção para o que pode ser considerado a unidade formal mais básica da tipografia, o desenho das letras. Estive interessada em saber que tipo de conjecturas o exame desses desenhos desencadeiam. Realizei sucessivas comparações das formas das letras num mesmo livro e entre eles, sempre atenta para as hipóteses que as análises permitem levantar. A principal delas é a hipótese de que pelo menos uma parte dos tipos utilizados na tipografia missioneira não teria sido fundido nas Reduções.

Não foi meu objetivo identificar a possível procedência dos tipos, compará-los com tipos utilizados em Lima, no México, na Espanha ou em outras partes. No âmbito desta dissertação me ative a análise exploratória dos desenhos, sem a intenção de identificar os tipos utilizados. Assim, as análises são descritivas e não almejam uma classificação do desenho das letras.

Além das letras impressas, me ocupei também de analisar as letras dos, não menos famosos, manuscritos guaraníticos. Não obstante a exaltação da imprenta guaranítica, as letras manuscritas são também um tema importante nas Reduções e na bibliografia sobre as Reduções. Nas Reduções - como na Europa (Cf. Bouza, 2001) - volumes inteiros eram copiados à mão em semelhança ao impresso, mesmo depois do advento da imprensa. Quando se trata destas letras, as manuscritas, a exaltação encontrada nos relatos jesuítas é menos relativa à extraordinária realização dos padres e mais à habilidade dos guaranis para copiarem as chamadas "letras de molde" - letras não-cursivas, desenhadas uma por uma em semelhança às letras impressas. As letras de molde são chamadas também de "letras de forma".

Os jesuítas não tinham em muita estima a inteligência dos índios, os quais viam como imitadores talentosos sem capacidade de criação. Esta é a opinião de vários 8 "the discovery of what was for Europeans a "new world" was very much articulated, mediated, and promoted by the printed word."
(MARTIN III, 2007:259) missionários que deram suas impressões sobre as missões. O padre Labbé, que chegou ao Prata em 1711, escreve em uma carta,

Não têm estes índios gênio inventivo; mas remendam todas as obras que vêem, com admirável destreza.Vi belas pinturas de suas mãos, livros impressos com grande correção, outros escritos com muita delicadeza [...] enfim, são excelentes em todas as obras artificiais, contanto que tenham diante de si uma mostra ou modelo.

(LABbÉ apud FURLONG, 1953a:70-71 - tradução minhaª)

O padre Francisco Jarque, que esteve nas Reduções no início do Século XVII, também aclama a habilidade dos guaranis para copiar letras,

Os indígenas com facilidade lêem qualquer letra de mão, ainda que seja de língua estranha para eles: os que escrevem chegam com sua pena a imitar tanto a melhor letra que copiam um Missal impresso em Antuérpia com tal perfeição que é necessária muita advertência para distinguir qual dos dois escreveu a mão do Índio e com este acerto copiam uma Sacra, das que servem para a Missa, estampada em Roma, com várias imagens da Paixão e Santos, tudo sua pena desenha, como se fosse molde. Assim em parte suprem os missioneiros a falta que há de imprensa alguma em toda aquela província.

(JARQUE apud FURLONG, 1953a:50 - tradução minha ${ }^{10}$ )

Como este, há outros relatos daquela época a respeito da aptidão dos guaranis para a cópia. Não poderia ser ao contrário, já que,

A escrita que imita a letra imprensa chegou a ser uma disciplina nas Reduções de Guaranis, ainda depois de existir entre eles a arte tipográfica. Nas Reduções havia escolas de ler em sua língua, em espanhol e latim, e de escrever em letra de mão e de molde.

(CARDIEL apud FURLONG, 1953a:52 - tradução minha ${ }^{11}$ )

Estes relatos ${ }^{12}$ ressoarão em clássicos da historiografia da impressão e da tipografia, em que a produção gráfica americana é vista, frequentemente, como uma duplicação

9 "No tienen estos indios genio inventivo; pero remendam todas las obras que ven, com admirable destreza. He visto pinturas todas las obras artificiales, com tal que tengan delante de sí una muestra o modelo." (LABBÉ apud FURLONG, 1953a:70)

10 "Con expedición leen cualquier letra de mano, aunque sea le lengua extraña para ellos: los que escriben llegan con su pluma a limitar tanto la mejor letra que copian un Misal impreso em Antuerpia, con tal perfección, que es necesaria mucha advertenci para dinstinguir cual de los dos escribio la mano del Indio y con estes acierto copian una Sacra, de los que sirven para la Misa, suplen los Misioneros la falta que hay de Imprenta alguna en toda aquella Provincia" (JROUE apud FURLONG, 1953:50)

11 "La escritura, que remeda la letra impresa, llegó a ser una disciplina en las Reducciones de Guaraníes, aun después de existir entre ellos el arte tipográfico. En las Reducciones hay escuelas de leer en su lengua, en español y en latín, y de escribir de letra de mano y de la de la molde." (CARDiel apud FURLONG, 1953a:52

12 Elogios à capacidade imitativa dos índios não é uma especificidade dos jesuitas das missões rio-platenses, há este tipo de relato também em outras parte do Novo Mundo (Cf. GRUZINSKSI, 1991). 
do que é produzido na europa. Updike, por exemplo, nos conta em seu Printing types, their history forms and use (1922) que, "a tipografia mexicana e sul-americana era, na maioria, uma cópia colonial do que era impresso no mesmo período em suas Pátrias Mãe." (UPDiKe, 1922:59 - tradução minha' ${ }^{13}$ ). O próprio Furlong, grande defensor da imprenta guaranítica, por um lado louva livros que dali saíam, por serem "all-american made",

[livro] composto por um indígena, e impresso por indígenas, em um povoado de indígenas. Bem cabe dizer desta obra que é um all-american made, todo de feitura americana.

(FURLONG, 1953b:IX — tradução minha ${ }^{14}$ )

Por outro, ressalta a incapacidade dos índios para a criação,

Se bem eram sumamente habilidosos para copiar, não eram para criar. O curto entendimento, ou mente embrionária dos mesmos [os índios] não lhes permite vôo mental algum. (FURLONG, 1953b:VI - tradução minha ${ }^{15}$ )

E, quando admite imperfeições nos livros, Furlong justifica que estes merecem consideração por terem sido feitos por índios,

foram talhados por mãos dos mesmos indígenas, com tanto empenho e carinho, e têm um encanto singular, não obstante as pequenas falhas que são manifestas.

(FURLONG, 1953b:VI — tradução minha ${ }^{16}$ )

Adotando a mesma perspectiva que adotei em relação aos impressos, me afastei ao máximo das narrativas sobre os manuscritos guaraníticos, narrativas que permanecem em torno do talento "natural" dos guaranis para a cópia. Como com as impressas, o objetivo das análises não foi encontrar uma "essência" das letras guaraníticas, o que faço é descrevê-las com a intenção de conhecê-las tal como elas aparecem nos livros, independentemente das narrativas sobre elas.

\section{Estrutura da dissertação e definição de termos básicos}

As análises das letras - manuscritas e impressas - estão no segundo capítulo desta dissertação. No primeiro, traço uma genealogia, dos guaranis e então dos jesuítas até

13 "Early Mexican and South American typography was, in the main, a colonial copy of printing of that period in the Mother Country. The books bore to the best Spa
printing of its time." (UPDIKE, 1922:59) 14 "compuesto por un indigena, e impreso por indigenas, en un pueblo de indigena. Bien cabe decir de esta obra que es un all-american
made, es todo él de factura americana." (FURLONG, 1953b:IX)

15 "si bien eran sumamente habilidosos para copiar, no lo eran para crear. El corto entendimiento, o mente embrionaria de los mismo, no les permitía vuelo alguno mental." (FURLONG, 1953b:VI)

16 "fueron tallados por manos de los mismos indígenas, con tanto empeño ojo cariño, y tienen un encanto singular, no obstante las pequeñas fallas que son manifiestas." (FURLONG, 1953b:Ix) a Bacia do Prata. O terceiro capítulo é uma extensão do segundo. Nele eu complemento as análises, apresentando impressões sobre aspectos das letras que me pareceram relevantes. Estas impressões eu apresento segundo a ideia de "inconstância", tomada emprestada da bibliografia de História Indígena e Antropologia que consultei ao longo da pesquisa - e a qual farei referência a seguir. Depois do terceiro capítulo traço as considerações finais.

Ainda a título de introdução, esclareço alguns termos que uso ao longo de todo o texto. A palavra "redução" se refere a colonização hispânica e sua política de reduzir a povoados várias parcialidades indígenas. Segundo Neumann, os termos "reduções", "missões", "doctrinas", ou "pueblos de indios" aparecem como sinônimos tanto nos documentos como na bibliografia sobre o tema (NEUMANN, 2005:13). Nesta dissertação uso "Reduções" ou "missões" como sinônimos "para designar as povoações de indígenas guarani convertidos à cristandade pelos missionários jesuítas" (neumann, 2005:13). Frequentemente uso os adjetivos "rio-platense", "jesuítico", "guaranítico" e "missioneiro". Nesta dissertação estes adjetivos são sempre relativos às Reduções de Guaranis na região da Bacia do Rio da Prata. Dessa forma, "tipografia rio-platense", "tipografia guaranítica", "tipografia missioneira" ou ainda "tipografia jesuítica guarani” são o mesmo: a tipografia nas Reduções de Guaranis do Prata.

Emprestado do espanhol, uso "imprenta guaranítica", onde "imprenta" é sinônimo de "impressora" enquanto empreendimento de impressão e não como o prelo em si. Assim, a "imprenta guaranítica" é o empreendimento de impressão das reduções guaraníticas.

No segundo capítulo, o capítulo das análises, faço uso de muitos termos técnicos específicos da tipografia - tipos, serifas, hastes, terminais - quando necessário, explicitarei o uso dos termos, ao longo do próprio capítulo. Por ora, esclareço apenas que uso "tipos" sempre como sinônimo de "tipos móveis".

\section{Revisão da literatura}

Há achados e apontamentos interessantes em estudos recentes que de alguma forma abordaram a produção livreira guaranítica ou a relação entre tipografia e línguas ameríndias. Stuart McKee, no seu How print came to be indigenous (МСКеE, 2010), questiona a forma como uma historiografia tradicional tratou a imprensa americana como fadada a duplicar a história da imprensa européia; e Marina Garone, em Historia de la tipografía colonial para lenguas indígenas (GARONE, 2009), aponta como jesuítas e religiosos de outras ordens viram-se obrigados a criar novas estratégicas sígnicas para adaptar as técnicas tipográficas às línguas indígenas na Nova Espanha. 
Fernanda Veríssimo investiga, em L'impression dans les Missions Jésuites au Paraguay: 1705-1727 (veríssimo, 2011), o funcionamento da tipografia nas missões, por meio de análise bibliográfica de todos os livros restantes da imprenta guaranítica; e Eduardo Neumann, faz considerações acerca do uso que os próprios guaranis conferiram à escrita, em Práticas letradas guarani: produção e usos da escrita indígena (séculos XVII e XVIII) (NEUMANN, 2005), nesta tese de doutorado Neumann faz uma sugestão, citando Josefina Pla, muito cara à presente pesquisa. Ele repete a mesma sugestão em artigo publicado dois anos mais tarde:

A cópia manuscrita de livros era uma prática muito comum na Europa, sendo o trabalho realizado por várias mãos, denominado pecia. Essa prática chegou a ser bastante difundida nas reduções, sobretudo diante da capacidade demonstrada pelos guaranis para as reproduções a partir de cópias. Provavelmente essa atividade deve ter contribuído para aperfeiçoar o trabalho executado pelos guaranis missioneiros como, por exemplo, no momento de confeccionar os tipos para a impressão.

(NEUMANN, 2007:183)

O que fica patente nesta sugestão é uma perspectiva que questiona a ideia de que os guaranis eram imitadores passivos e considera sua contribuição aos ofícios missioneiros. Ao desconfiar das narrativas dominantes sobre os livros guaraníticos, esta dissertação dialoga com este tipo de perspectiva.

$\sim$

A resistência indígena, os costumes dos povos ameríndios e a forma como influenciaram os europeus há muito estão presentes na historiografia colonial brasileira. João Capistrano de Abreu (1853-1927) e Sérgio Buarque de Holanda (1902-1982), representando momentos preciosos desta historiografia, endereçaram, cada um à sua maneira, a importância do índio para a compreensão de processos históricos.

Afastando-se da historiografia eurocêntrica de Varnhagen (1816-1878), ainda predominante em seu tempo, Capistrano realiza estudos etnográficos e lingüísti$\cos ^{17}$, como o publicado em Rã-txa $h u-n i-k u-\tilde{i}$ (CAPISTRANo, 1914) no qual estão compiladas mais de cem narrativas tradicionais, além de um vocabulário brasileiro-caxinauá e outro caxinauá-brasileiro com milhares de verbetes cada um. Já Sérgio Buarque não só estudou hábitos e costumes indígenas, como a influência destes sobre homens e mulheres europeus. O fez incipientemente em Raízes do

17 As incursões de Capistrano de Abreu pela etnolingüística foram apreciadas por Beatriz Christino, para quem "seu interesse pelas línguas e culturas indígenas vinculava-se de modo direto à sua concepção de história." (CHRISTINo, 2007:39) e "Sua obra tão ameaçadas culturas indígenas." (CHRISTINO, 2007:62)
Brasil (BUARQUE DE HOLANDA, 2006 [1936]) tratando de apontar a "extraordinária capacidade dos povos tupi-guaranis para tupinizarem os povos estranhos à sua raça" (BUARQUE DE HOLANDA, 2006:201) e definitivamente em Caminhos e Fronteiras (BUARQUe DE HOLANDA, 2008 [1956]), no qual dedicou toda a primeira parte Índios e Mamelucos - ao assunto.

Tributários deste arcabouço historiográfico são muitos trabalhos de uma história social que faz-se mais presente no Brasil desde a década de noventa, em crescente diálogo com a sociologia, antropologia, etnografia e etnologia, áreas que contam com as importantes obras de Florestan Fernandes, Manuela Carneiro da Cunha, Eduardo Viveiros de Castro, Lévi-Strauss, Pierre e Helène Clastres e Alfred Métraux. ${ }^{18}$

Nesta "História Indígena" ou "Etnohistória" — ou ainda "Nova História Indígena", como a chamou John Manuel Monteiro, cujo trabalho Negros da Terra (1994) traz em definitivo esta postura à historiografia brasileira - estão, entre outros, os trabalhos de Ronaldo Vainfas (1995), Cristina Pompa (2003), Maria Regina Celestino Almeida (2003) e Pedro Puntoni (2002), nos quais examina-se o papel ativo das populações indígenas no mundo colonial, suas estratégias de ação e reação frente ao colonizador, as formas alternativas de sobrevivência que estabeleceram, o papel das elites indígenas, sua capacidade de mobilização política, negociação e resistência, as apropriações de formas cristãs e significados alternativos a elas atribuídas.

Subjacente aos trabalhos destacados, há uma idéia contrária a do índio passivo, o qual ajusta-se de forma resistente à ordem colonial, mobilizando as possibilidades a seu alcance para atingir interesses próprios, que evidentemente se transformavam na nova situação colonial. John Manuel Monteiro, ao tratar do processo de ajustamento do índio à sociedade escravista, usa o termo "adaptação resistente" de Stern, para referir-se a um "determinado nível de integração, onde o índio forjava espaços de sobrevivência no interior de sua nova realidade social" (MONTEIRO, 1994:174).

A "mudança de postura” que gesta a Nova História Indígena está inserida num quadro mais amplo de mudanças, impulsionada por renovações teóricas e metodológicas nas ciências humanas em geral que tomaram curso nos anos 1960 e 1970. Neste âmbito, críticas políticas sugeriam uma reflexão sobre as origens colonialistas da antropologia e sobre as relações de poder embutidas nessas teorias. De acordo com Hill (1992), os trabalhos de Said (2007 [1978]) e Fabian (1983) marcaram a mudança para uma abordagem reflexiva e historicamente orientada da antropologia. Assim, uma aproximação não se deu apenas da história para a antropologia, mas também da antropologia para a história, proporcionando a compreensão da cultura como produto histórico, dinâmico e flexível formado pela articulação entre

18 Me refiro, em particular, às obras: A função social da guerra na sociedade Tupinambá (FERNANDES, 1970 [1952]); História

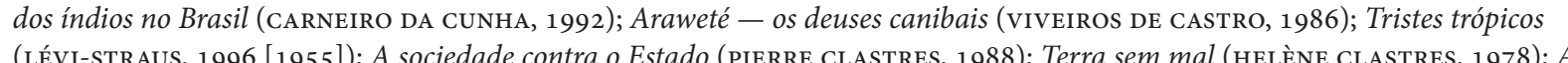
religião dos Tupinambás (MÉTRAUX 1979). 
tradições e novas experiências vividas por pessoas, o que permite perceber a mudança cultural não apenas enquanto perda ou esvaziamento de uma cultura dita autêntica - o pressuposto da aculturação - mas em termos do seu dinamismo, mesmo em situações de contato - o pressuposto da transculturação. Sem desconsiderar a violência e a opressão da conquista, é possível perceber que as atitudes dos índios em relação aos colonizadores não se reduziram à resistência armada e à submissão passiva.

A defesa dos aspectos sociológicos e históricos da cultura deve-se em grande parte a E. P. Thompson, historiador, cujas idéias associam cultura e classe, ambas entendidas como processo, formadas através do tempo. Thompson valorizou o cultural, associando-o ao conceito de classe e consciência de classe que, segundo ele, se formam conjuntamente, no processo histórico, "num processo ativo que se deve tanto à ação humana como aos condicionamentos" (THOMPson, 1987:9). Cultura para Thompsom é, assim, um produto dinâmico que deve ser apreendido no processo histórico, no qual homens e mulheres vivem suas experiências (THOMPSON, 1981:182).

Bebendo em Thompsom e Said, poscolonialistas como Homi Bhabha continuam a refinar as questões da aculturação ou transculturação, focando na recepção. Bhabha identifica diversas possibilidades de reações a uma cultura "recebida", que passam pelo engano ou equívoco (do inglês, misinterpretation), a mímica, a multiplicação de significados, e a hibridação (BHABHA, 1998 [1994]). Gruzinski, trabalhando temas da Nova Espanha colonial, explorou a questão da recepção como esta definida por Bhabha, reconhecendo as dialéticas do desentendimento, apropriação e alienação (GRUZINSKI, 1993). Este autor problematiza categorias dadas como naturais, enfatizando as adaptações e reapropriações praticadas pelos índios diante dos modelos da cultura ocidental. O autor também traz a ideia de imperfeição intencional (do inglês, decided imperfection) ao tratar das cópias de gravuras européias feitas pelos nahuas, da América Central. Para ele, a imperfeição intencional destas gravuras deve-se mais a uma interpretação da linguagem européia do que a uma falta de habilidade do nativo (GRUZINSKI, 1993:187 - tradução minha ${ }^{19}$ ).

Os estudos culturais, em especial sua vertente pós-colonialista, nos fornecem ferramentas teóricas importantes para abordar a história da imprenta guaranítica na medida em que, para além de uma dialética do encontro, permite olhar criticamente o ponto de vista de onde esta história é contada. Não se trata de reivindicar uma historiografia do livro que busque compensar grupos étnicos ou períodos históricos invisibilizados. Ao contrário, o olhar pós-colonial possibilita uma aproximação ao "objeto de estudo" com atenção crítica ao ponto de vista com que foi historicamente

19 "The decided imperfection [...] is to be attributed more to an interpretation of European language than to native clumsiness". (GRUZINSKI, 1993:187) observado. Lançando mão desta perspectiva, é menos minha intenção reivindicar um olhar para as letras desenhadas nas missões que revele a "contribuição" ou a "apropriação" ou o "protagonismo" guarani na produção livreira das Reduções Jesuíticas e mais minar o ponto de vista do qual estes livros vêm sendo estudados.

Independente do nome que adotamos, seja "aculturação" , "transculturação", "hibridação" "apropriação", "engano", "desentendimento" ou qualquer outro dos termos apresentados, o aspecto do intercâmbio intercultural em que repousa nosso objeto de pesquisa - o desenho das letras - é a arte. Aculturação na arte é uma das questões mais acaloradamente contestadas da história da arte do período colonial. Apesar de que muitos estudiosos reconhecem que um tanto de hibridação existiu, poucos concordam sobre que nome dar (BAILEY, 2001). Um dos nomes mais populares é "mestizo" (em português, "mestiço"), um termo de historiadores da arte mexicana e peruana no inicio do Século XX que aproxima o sincretismo nas artes à miscigenação racial. Embora a ideia de arte como produto racial não seja mais aceita, o termo "mestizo" continua sendo muito usado (BAILey, 2001:4). A arte do período colonial produzida especificamente nas missões jesuíticas também sofrem do mesmo problema de nomenclatura. Ainda que quase toda a arte e arquitetura das missões jesuíticas tenha sido produzida com a participação mais ou menos voluntária de comunidades indígenas e possa ser descrita como um híbrido (вAILEY, 2001:5 - tradução minha ${ }^{20}$ ), a vasta bibliografia sobre esta arte adota diferentes nomenclaturas, como "estilo mestizo" ou "barroco missional" (Cf. WAISMAN, 2011).

Para as artes das missões guaraníticas do Prata, Josefina Pla sugeriu o termo barroco hispanoguaraní (PLA, 1975 e 1973), o qual descreve como uma arte que se desenvolve na articulação entre a eficiência do trabalho missioneiro e a capacidade do guarani converso (PLA, 1973:54).

Não é objetivo desta pesquisa encontrar um "estilo próprio" das letras rio-platenses. De forma que não importa tanto se me refiro as letras impressas e manuscritas nas missões como "letras rio-platenses" ou "letras hispanoguarani". Entretanto, como mencionei anteriormente, compartilho algumas impressões sobre o desenho das letras no capítulo III e para isso emprego o termo "iconstância".

A "inconstância" é um tema muito presente na bibliografia sobre a catequização. O padre Antônio Vieira no seu célebre sermão do Espírito Santo, realizado na Igreja da Companhia de Jesus de São Luís do Maranhão, no ano de 1657, fez uma comparação entre as dificuldades da catequese desses índios e o trabalho de um escultor (Cf. PÉCORA, 2003). Para o missionário, esses índios, os "brasis", não ofereciam nenhuma resistência inicial ao processo de catequese, ao contrário, abraçavam a fé sem muita dificuldade. No entanto, com o passar do tempo, do mesmo modo que a abraçavam também dela se desfaziam com a mesma facilidade. Neste sentido, diz o

20 "Most art and architecture on the Jesuit missions was produced with the more or less willing participation of indigenous communities, and almost all of it can be described as a hybrid" (BALEY, 2001:5) 
missionário, comparavam-se a uma estátua de murta (um arbusto) cuja produção não oferecia dificuldades ao seu escultor. Por outro lado, era preciso estar sempre atento e, a todo o momento, era imperativo poda-la para que permanecesse em perfeito estado. $\mathrm{O}$ contrário disso acontecia com outros povos que a princípio eram duros, tenazes, constantes e resistentes ao processo de catequese, tal qual o mármore era duro para ser trabalhado. Apesar disso, depois de produzida, a estátua de mármore durava para a eternidade. Com os "brasis" restava a eterna tarefa de trabalhar o já trabalhado, plantar o já plantado e ensinar o já ensinado. Usando essa imagem do missionário Vieira, Viveiros de Castro escreveu um importante ensaio intitulado $O$ mármore e a murta - sobre a inconstância da alma selvagem (VIVEIROS DE CASTRO, $2011[2002])$, em que reflete sobre a visão que o jesuíta construiu dessas populações e a perspectiva das populações de origem tupi quanto à visão da alteridade e sobre a "inconstância" ao abraçarem valores do "outro". "Inconstância" essa que Viveiros considera uma característica fundadora dessas populações.

$\sim$

Sobre os guaranis da Bacia do Prata nas Reduções Jesuíticas, há também estudos que compartilham desta "nova postura" na historiografia, como verifica-se em Lía Quarleri (2009), Guillermo Wilde (2009) e Eduardo Neumann (2005). Nestes trabalhos, a ênfase é no protagonismo dos guaranis e suas lideranças frente aos mandos e desmandos das autoridades coloniais locais e da coroa (QUARLERI, 2009); nas situações de ambigüidade e ambivalência onde os guaranis organizaram suas relações sociais e manipularam símbolos, gestos e objetos a despeito do olhar vigilante da administração colonial (WILDE, 2009).

Neumann se ocupou especificamente dos usos que os próprios guaranis fizeram da escrita, com atenção especial aos escritos produzidos durante a Guerra Guaranítica. Ainda que não seja sua preocupação o desenho das letras guaraníticas manuscritas, este autor nota que "uma leitura atenta do material permite identificar o grau de familiaridade do escrevente com os instrumentos básicos para essas tarefas, como eram a tinta e o papel" (NeUmann, 2005:27).

A perspectiva por eles adotada permite perceber que os guaranis exerceram nas Reduções práticas culturais e políticas que lhes permitiam colaborar e negociar com a sociedade colonial em busca de possíveis vantagens, apesar das grandes perdas culturais e étnicas sofridas. Esta abordagem por um lado vai além da exaltação de heróis, ou mártires e por outro abandona a freqüente exaltação dos padre da Companhia de Jesus, que vigorou em parte dos estudos sobre as Reduções Rioplatenses, especialmente aqueles produzidos por autores jesuítas, como Furlong.

Dos que trataram especificamente das artes nas missões, eu não poderia deixar de citar Josefina Pla, que em seu Los talleres misioneros (1609-1767). Su organización $y$ funcionamiento (1973), resume muito bem a questão - espinhosa - da agência indígena no contexto da produção artística das Reduções Jesuíticas Guarani,

A indubitável habilidade do indígena artesão não dá como resultado a cópia fiel e acadêmica que poderia supor-se de acordo com estes testemunhos [relatos de jesuítas e viajantes], senão uma versão de sabor peculiar, onde as formas aparecem infusas de ritmos e cânones distintos. Com isso não se pretende diminuir o mérito desses desenhistas e gravadores; o feito assombro da assimilação de técnicas, permanece, e basta para qualificá-lo como magníficos artesãos. Por outro lado, esse feito coloca uma das questões mais espinhosas e também mais interessantes de um meio e momento histórico dados, e do jogo de circunstâncias sócio-culturais inéditas: de fato, nos perguntamos: essa incapacidade manifesta do indígena para reproduzir o modelo em sua integridade plástica, canônica e rítmica, foi o resultado lógico da forma em que se desenvolveu sua aprendizagem artística, limitada a cópia literal: sempre fruto, em suma, de uma insuficiência funcional. Ou é o melhor reflexo, ao nível ingênuo, da luta entre os ritmos impostos pela cultura importada, de um lado, e a vontade de forma própria urgindo no pulso do artesão e reprimida pelas diretivas da oficina, por outro?

(PLA, 1973:40 - tradução minha $\left.{ }^{21}\right)$ $\sim$

Minhas próprias motivações para engajar-me nesta pesquisa remetem a estudos sobre tipografia e línguas indígenas que iniciei na graduação. Uma primeira análise de publicações em línguas indígenas utilizados em escolas indígenas hoje, me permitiu desconfiar que existe um descompasso entre técnicas disponíveis para impressão de texto (fontes digitais, por exemplo) e grafia de línguas minoritárias (as línguas indígenas, por exemplo) (DINIZ, 2007). Assim, examinar a produção livreira rio-platense é para mim uma espécie de interlúdio histórico: compreender como uma certa técnica - a impressão com tipos móveis - e uma língua indígena específica - o guarani - adaptaram-se uma a outra no período colonial, poderá, quem sabe, elucidar esta questão maior que me interessa a longo prazo

21 La indudable habilidad del indigena artesano no da como resultado -lo repetimos una vez más-la copia fiel y académica que podría suponerse de acuerdo a esos testimonios, sino una versión de sabor peculiar, donde las formas aparecen infusas de ritmos y cánones distintos. Con esto no se pretende ni mucho menos disminuir el mérito de esos diseñadores y grabadores; el hecho asombroso de la asimilación de técnicas, permanece, y basta a calificarlos como magnificos artesanos. Por otro lado, ese hecho platea una de las cuestiones más espinosas y también mas interesantes de un medio y un momento historico dados, y del juego de circunstancias socioculturales inéditas. En efecto, nos preguntamos: Esa incapacidad manifiesta del indigena para reproducir el modelo en su integridad plástica, canónica y rítmica, fue el resultado lógico de la forma en que se desenvolvió su aprendizaje artístico, limitado a la copia literal: simple fruto, en suma, de una insufficiencia funcional. O refleja ella más bien, al nivel ingennu artesano y reprimida por las directivas de taller por otro? (pis, 1973:40) 


\section{GUARANIS E ESCRITA NA BACIA DO PRATA}

\subsection{GUARANIS - 2000 ANOS ATÉ A BACIA DO PRATA}

A América do Sul guarda grandes aquíferos e bacias hidrográficas, que irrigam uma enorme diversidade biológica, botânica, étnica e uma das maiores diversidades lingüísticas do mundo (RODRIGUES, 1993). Ao norte, o rio Orinoco nasce no Monte Roraima, recolhe águas dos rios Meta, Arauca, Manapiri, Suatra, Caura, Caroni, em regiões habitadas por falantes de línguas da família karib, e vai desaguar no mar de mesmo nome, o Mar do Caribe ${ }^{22}$.

O rio Amazonas recolhe águas que vêm do sul desde Cochabamba e Potosi pelos rios Beni e Mamoré até o Madeira, e outras que vêm do norte, trazidas no rio Branco, onde também estão muitas línguas da família karib, até o Rio Negro, área de línguas da família aruak. Os rios Içana, nascente na Colômbia, e Purus, nascente no Peru, banham mais regiões de línguas aruak, enquanto o Solimões vem desde o Equador, passando por áreas de línguas da família tupi-guarani. Águas do Planalto Central e Pantanal trazidas pelos Rios Xingu e Tapajós, também se juntam ao Amazonas, um pouco antes de seu desague no Atlântico. Pelo caminho vêm banhando outras regiões tupi-guarani.

A bacia hidrográfica do rio Amazonas guarda línguas de outras famílias além das mencionadas - tupi-guarani, aruak e karib -, mas são estas as três famílias predominantes na região. Entretanto, enquanto as línguas da família aruak e karib são essencialmente amazônicas em sua distribuição, as línguas da família tupi-guarani são essencialmente sul-amazônicas, com apenas 4 línguas ao norte do rio. O que não impediu que estas línguas compartilhassem palavras entre si: línguas tupi-guarani tomaram de empréstimo da família karib cerca de 100 nomes de plantas, animais e objetos culturais. Resultado não de uma ancestralidade comum (o proto-tupi), mas de alguma convivência próxima (RODRIGUES, 1993). 
Uma rápida olhada no Mapa etno-histórico do Brasil e regiões adjacentes de Curt Nimuendajú (1981) [MAPA 1] permite imaginar os movimentos migratórios de falantes das línguas destas três famílias. Enquanto a maioria das línguas karib e aruak ficam na Amazônia (rosa claro e azul claro), as línguas da família tupi-guarani (laranja) espalham-se em direção ao rio Tocantins, e daí para a costa atlântica, ocupando o litoral até a Lagoa dos Patos. Espalham-se também ao sul pelo rio Tapajós, até alcançarem os rios Paraná e Paraguai.

Os rios Paraná e Paraguai formam uma outra bacia hidrográfica, abaixo dos trópicos. O primeiro rio traz águas do Paranapanema e Tietê e águas do Rio Paranaíba,

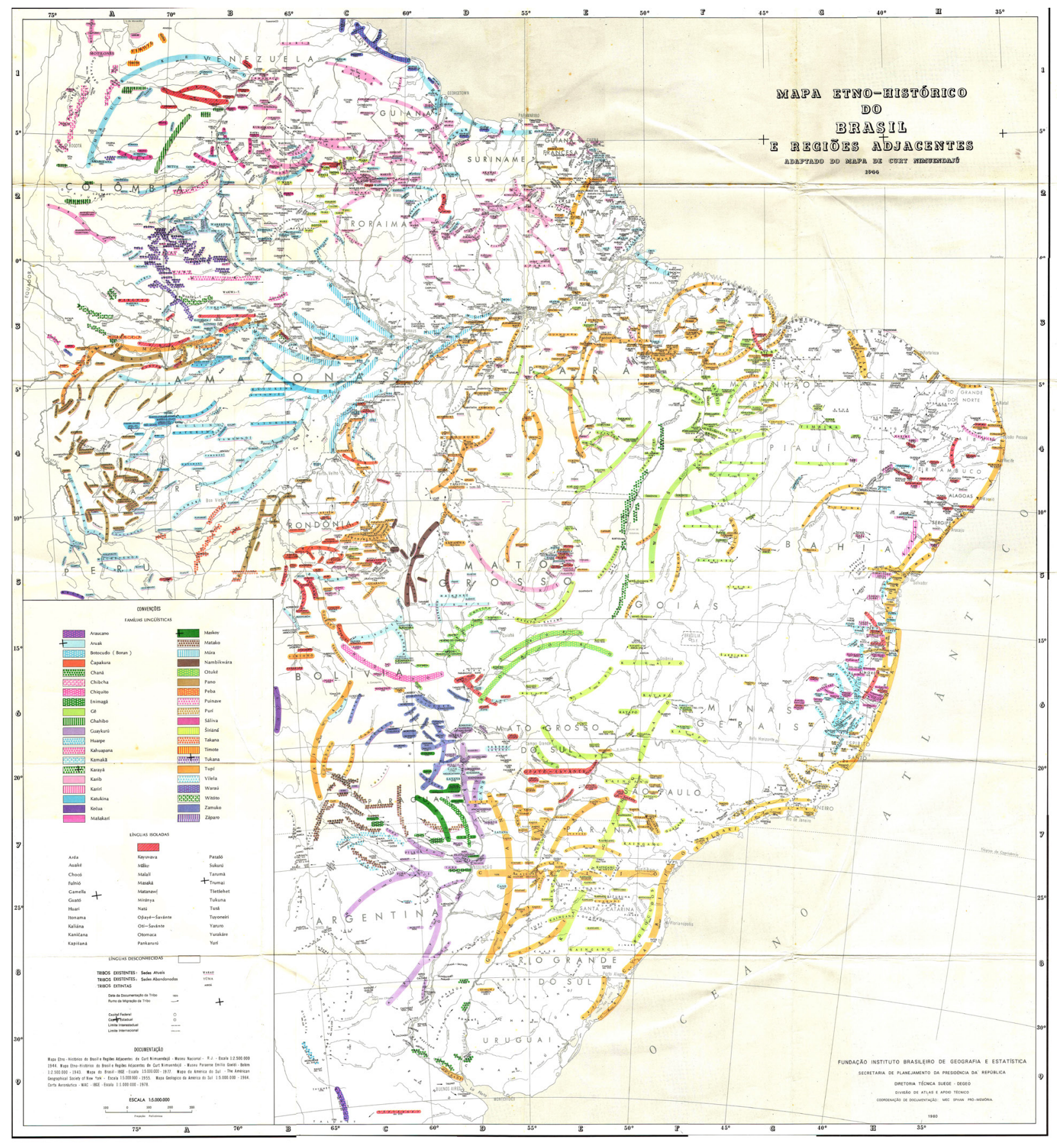

[MAPA 1] Mapa etno-histório do Brasile regiões adjacantes de Curt Nimuendajú (1981). com afluentes tão longínquos quanto Goiás. O segundo traz águas do Pantanal e do Chaco boliviano. Há ainda o rio Uruguai, que recebe águas do rio Iguaçu, nascente nas proximidades de Curitiba. Esta é a Bacia do Prata.

Desde a Bacia do Orinoco, até a Bacia do Prata, não faltam rios, por onde, há milhares de anos as populações sul-americanas movimentam-se em busca de terras melhores, em fuga de povos inimigos ou adversidades climáticas, ou simplesmente em razão de sua expansão demográfica. Esta expansão territorial começou há aproximadamente dois mil anos atrás (NOELLI apud QUARLERI, 2009:29), deu-se lenta e continuamente, atravessou várias gerações, colocou as línguas tupi-guarani em contato com outras não-amazônicas e deu origem a variações dialetais e grupos étnicos que tornaram-se algumas vezes inimigos entre-si. Os que chegaram ao mar são os de língua tupinambá, e os que chegaram ao Prata são os de língua guarani.

No Século XVI estas línguas eram as únicas da família tupi-guarani que já estavam fora da Amazônia (RODRIGUES, 2000). Apesar das diferentes direções tomadas, os homens e mulheres falantes destas línguas e seus dialetos se encontrariam muitas vezes. Diretamente, ou mediados por falantes de outras línguas ainda. Supõe-se que conhecer falantes de línguas diferentes da sua própria era algo comum em uma América tão diversa (MELIÀ, 2010).

Esta diversidade foi experimentada por parte dos guaranis que na descida ao Prata estabeleceram-se nas fronteiras dos Andes, uma área extremamente multiétnica ao tempo do Tawantinsuyu, o Império Inca (PÄRssINEN, 2003). Nesta região estabeleceram relações de parentesco com outros povos, por meio de casamentos interétnicos. Muitos chiriguanos - os guaranis eram assim chamados pelos incas - eram filhos de mães chanés (MÉTRAUX, 1948:467-481).

Talvez os chiriguanos estivessem nesta região desde o Século VI, mas independente da precisão na data de sua chegada, sabe-se que os guaranis não só tinham conhecimento do Tawantinsuyu como guerrearam contra este império ${ }^{23}$. Conheciam, desde estas épocas, as artes figurativas andinas, pelas quais não demonstravam interesse, preferindo seus padrões e ritmos geométricos. Segundo Bailey (2001),

Antes do contato com os europeus, eles [os guaranis] mostravam desinteresse por imagens figurativas, mesmo que este tipo de imagem estivesse disponível para eles por séculos devido às trocas comerciais com as terras andinas. A arte não tinha como fim imitar a natureza, mas revelar sua essência, especialmente por meio de formas geométricas de expressão.

23 Evidencias de uma invasäo guarani a fortaleza inca de Cuzcotoro em 1520 foram apresentadas pela primeira vez em 1917 por Erland Nordenskiold. No mesmo ano, Philip Means (1917) reforçou a validade das evidencias, mas questionou se esta teria sido a primeira invasão dos guaranis ao Imperio. Desde então muitos estudiosos debateram o assunto, entre eles Métraux (1948), que comprovado a tese de que os guaranis estiveram nesta área há mais de mil Xnos ano entanto, pesquisas arqueologicas recentes tên este estudo interessa saber apenas que os povos guaranis tinham contato com diversos povos, inclusive com os poderosos incas. 
(BAILEY, 2001:144 - tradução minha ${ }^{24}$ )

E conheciam também as políticas lingüísticas incaicas de utilização de uma língua geral, uma koiné, de base quéchua. ${ }^{25}$

Muitos grupos mantinham suas línguas étnicas, e eram bilingües/diglóssicos com essa koiné de base quechua, com um bilingüísmo seletivo, isto é, não extensivo a todos os membro da comunidade. [...] Essa língua geral servia para a administração incaica porque garantia a comunicação de diferentes redes do Império: administrativa, política, econômica. Esta língua é adotada pelos últimos imperadores cusquenhos [...]. A língua geral funciona até nas áreas periféricas; mesmo sem ser universal, é usada pelos governantes locais, burocratas e comerciantes.

(ALFARo, 2001:36)

Assim se relacionavam os guaranis com os diversos povos com que tiveram contato: tomando palavras emprestadas, como fizeram na Amazônia com os karib há milhares de anos atrás; por meio de alianças reforçadas em laços de parentesco, como fizeram com os chanés nas beiradas do Tawantinsuyu; outras vezes em combates mais arriscados e belicosos, como fizeram com os incas, de quem também aprenderam a língua geral ${ }^{26}$. Uma constante em sua prática é também a disposição a aventurarem-se de um lugar para outro.

Os primeiros guaranis que aventuraram-se até o Prata chegaram ali há aproximadamente mil e duzentos anos (NOELLI apud QUARLERI, 2009:29). Encontraram nesta região povos falantes de línguas da família jê, como os kaingangs e botocudos, da família guaicurus, como os payaguas e guaricurus, e línguas sem família, ou isoladas, como os charruas. Estes grupos estavam no Prata há mais de onze mil anos (sUSNIK apud QUARLERI, 2009:38). Além das línguas, os guaranis tinham de diferente em relação a estes povos o uso da agricultura, que lhes permitia permanecer por

24 "Before contact with Europeans, they [the Guarani] had shown a disinclination toward figural imagery, even when it was available to them for centuries through trade goods from the Andean highlands. Art's goal was not to imitate nature but to reveal its essence by means of largely geometrical forms of expression." (BALEE, 2001:144)

25 Segundo Consuelo Alfaro, a língua geral imposta pelos Inca, seria mais tarde aproveitada por invasores espanhóis. De acordo com esta autora,

"Essa profusão de línguas já consignada por cronistas espanhóis e indios, caminhava para a formação de um língua, denominada na administracäo incaica. conquistadores, como instrumento de conquista e colonização." (ALFARO, 2001:36)

26 Fiquei muito curiosa para saber se os guaranis tomaram conhecimento dos Quipus, um possivel sistema de escrita incaico, mas não achei bibliografia sobre o assunto. Em geral, a bibliografia acerca dos Quipus detềm-se ao "Paradoxo Inca." Também me interessa saber se foram expostos à polifica de povoamento dos Inca, 'A politica de povoamento dos governantes cusquenhos tinha como modelo um tipo de aménagement" territorial em que grupos étnicos eram transladados massivamente de um lado a

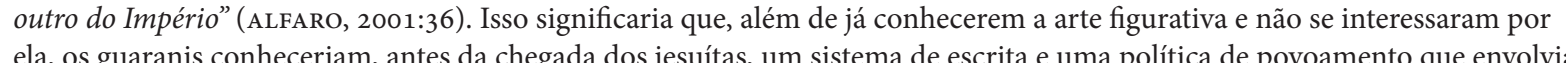
ela, os guaranis conheceriam, antes da chegada dos jesuitas, um sistema de escrita e uma politica de povoamento que envolvia
procedimentos parecidos com os impostos pelos jesuitas, nas Reducốes. mais tempo em uma mesma região. Trouxeram para o Prata suas técnicas e hábitos, além do conhecimento adquiridos no contato com outras culturas.

Pois assim estavam os guaranis e as guaranis da bacia do Prata ao início do Século XVI: com uma população estável, ocupavam de forma irregular áreas banhadas pelos rios Paraguai, Paraná e Uruguai, desde suas nascentes em Goiás e São Paulo e desde o Chaco e Pantanal até a costa, na Lagoa dos Patos. Desfrutavam de certa tranquilidade, senhores que eram da região, apesar dos frequentes ataques a suas aldeias. Para defenderem-se mantinham-se alertas, com o costume de vigiar as fronteiras de seus territórios (QUARLERI, 2009:50).

\subsection{ESCRITA - 2000 ANOS ATÉ A BACIA DO PRATA}

Vigiando suas fronteiras, os guaranis perceberam ao alvorecer do Século XVI o movimento de novos ocupantes na região, primeiro de forma esporádica e mais tarde ostensivamente. Notaram e resistiram à primeira entrada de espanhóis ao estuário do Prata, em 1516, como notaram expedições portuguesas, novos fortes e acampamentos, e um número cada vez maior de homens e mulheres adentrando seus domínios e impondo-se com armas e estratégias que desconheciam.

Os vários grupos guaranis reagiram de variadas formas frente a esta presença, de acordo com o local e condições em que encontravam-se, com suas possibilidades de reação e suas experiências prévias (Cf. sUSNIK, 1980). Guaranis do grupo cario, volúveis por encontrarem-se em região de forte domínio paragua, seus inimigos tradicionais, após uma tentativa frustrada de impedir a passagem de uma expedição espanhola, juntaram-se aos espanhóis na esperança de assim enfrentarem seus tradicionais inimigos. A cooperação destes guaranis com espanhóis foi essencial para a permanência dos primeiros e estabelecimento dos segundos na região,

estavam dispostos a abastecer aos espanhóis com alimentos, madeira e muitos outros produtos. Lhes proporcionavam, ademais, todo tipo de assistência pessoal, estavam prontos a acompanha-los em suas expedições e colocavam a sua disposição o conhecimento que tinham da região.

(KLEINPENNING ${ }^{27}$, 2011:70 - tradução minha ${ }^{28}$ ).

O estabelecimento dos espanhóis na região deu-se, principalmente, a partir da fundação, em 1537, de um posto de apoio fortificado, que levou o nome de Nuestra Señora de Santa Maria de la Asunción. A partir de 1541 a população europeia estava

27 Todos as informações demográficas das Reduções - bem como as datas e locais de fundação de cada povoado - a que faço referência nesta dissertação, seguem os dados de Kleinpenning (2011), no extenso volume Paraguay 1515-1870: Una geografía temática de su desarrollo.

28 "estaban dispuestos a abastecer a los españoles con alimentos, madera y muchos otros productos. Les proporcionaban, además todo tipo de asistencia personal, estaban prestos a acompañarlos en sus expediciones y ponian a su disposición el conocimiento qu
tenian de la región" (KLEINPENING 2011:70) 
concentrada completamente em Asunción (KLEINPENNING, 2011:72) e dali saíam expedições para fundar novos assentamentos: em 1561 estava fundada Santa Cruz de la Sierra; em 1573 Santa Fé; em 1580 Buenos Aires; em 1588 Corrientes; entre outros assentamentos não exitosos. A esta altura, havia já a primeira geração de mestiços na região, resultado das uniões entre os primeiros conquistadores e mulheres entregues por chefes guaranis (QUARLERI, 2009:65-66).

Em outra das extremidade da bacia do Prata, lá na longínqua nascente do rio Tietê, estava a Vila de São Vicente, fundada cinco anos antes de Asunción, em 1532. São Vicente, como Asunción, concentrava europeus, mas os de lá eram portugueses, enquanto os de aqui eram espanhóis. Desde uma ponta e desde a outra, os europeus empenhavam-se na conquista dos rincões rio-platenses. A oposição entre estes dois pólos marcaria pelos próximos séculos a vida dos guaranis e de todas as populações que habitavam o Prata.

Além da fundação de assentamentos, foram parte dos esforços de conquista e colonização espanhola do Prata as rancheadas e as encomiendas (Cf. QUARLERI, 2009). Rancheadas eram ações de captura e escravização de mulheres e homens guaranis, principalmente para venda aos paulistas, em São Vicente. Encomiendas eram uma forma jurídica de exploração da mão de obra nativa indígena por um encomiendero espanhol, a quem um número regulado de índios deveria pagar tributos em troca de proteção e em troca de permanecer na terra. Na prática, as encomiendas consistiram também na escravização das populações originárias. O sequestro e a exploração da mão de obra indígena escravizada por meio das rancheadas e do sistema de encomiendas estava na base da economia de Asunción (QUARLERI, 2009:60).

A partir de São Vicente também os portugueses recorriam o interior em busca de mão de obra escrava. Em 1554 estava criado naquelas cercanias o colégio jesuíta de São Paulo de Piratininga, que deu origem ao assentamento de mesmo nome e logo à fundação de uma vila. Lá chamavam não de rancheadas as entradas ao sertão, mas de bandeiras de preação. A bacia do Prata estava cada vez mais marcada pelas rotas comerciais de mão de obra entre São Vicente e Assunção, pela exploração gerada pelas encomiendas, a captura e escravização de mulheres e homens guaranis, pela expropriação e extermínio. Em diferentes épocas, dependendo dos arranjos políticos nas coroas ibéricas, acirravam-se ou arrefeciam-se os conflitos na região (Cf. QUARLERI, 2009) - a partir de 1580, com a união das coroas, a rivalidade entre espanhóis e portugueses foram temporariamente amenizadas; Buenos Ayres se tornava uma via de comunicação entre o sertão, o Atlântico e Lima, o que levou a consolidação de uma nova rota comercial entre o Prata e São Paulo; algumas décadas mais tarde, o domínio holandês sobre a costa atlântica fez cair o tráfico negreiro que fez aumentar as capturas de mão de obra indígena no Prata. A todas estas mudanças estavam suscetíveis os guaranis, que dependendo do momento, resistiam a presença européia com mais ou menos repelo (Cf. MONTEIRO, 1994). Em meio às turbulências, o certo é que esta zona fronteiriça imprecisa e sob disputa de espanhóis e portugueses, se tornara hostil e perigosa para os guaranis: no final do Século XVI vivem seu primeiro declínio populacional desde os anos de bonança prévios a chegada dos europeus (Cf. KLEINPENNING, 2011).

No final do Século XVI os Guaranis estão mais densamente agrupados no Guayrá, região de planaltos e matas araucárias que vai da costa atlântica, a leste, até o rio Paraná, a oeste. Entre os limites do rio Iguaçu, ao sul, e Paranapanema, ao norte, o que coincide, mais ou menos, com o atual estado do Paraná. Apesar do declínio populacional que viviam, eram duzentos mil guaranis no Guayrá (KLEINPENNING, 2011:78). Não estavam isolados, claro: já em 1553 uma delegação de caciques pedia auxílio aos espanhóis para defenderem-se de ataques de paulistas, o que levou a fundação dos primeiros assentamentos espanhóis no Guayrá - Ciudad Real e Villa Rica - e, consequentemente, as primeiras encomiendas naquela área. Mas foi apenas no início do Século XVII que viram os europeus mais insistentemente por ali: em 1604 estava determinada a área de abrangência da "Província do Paraguai", onde deveriam atuar os jesuítas e a partir de 1609 estes padres começam suas investidas na região, concentrando os guaranis em "reduções".

Eram as primeiras Reduções Jesuíticas Guarani, no Guayrá: Em 1610, na margem do Rio Paranapanema, onde desaguava o rio Pirapó, o cacique Aticaya permitiu a fundação da Redução de Nossa Señora de Loreto del Pirapó e logo, na outra margem do rio, a de San Ignacio de Ytaumbuzú. Em 1612 nas duas Reduções viviam seis mil guaranis e havia escolas para instrução religiosa de centenas de alunos, que também aprendiam - em alguma medida - a ler e escrever (Cf. MELIÀ, 1992).

Desde o princípio, a conquista espanhola teve a seu favor a conquista espiritual e não foram os jesuítas os primeiros religiosos nesta frente nem os primeiros a fundarem Reduções. Redução, no português, ou reduccíon, no espanhol, deriva do latim. O verbo reducere em latim significa conduzir junto, ou conduzir de volta. As Reduções eram, assim, agrupamentos, onde estavam "conduzidos a um mesmo local" várias parcialidades indígenas, o que foi feito antes por padres Franciscanos, nas cercanias de Asunción (Cf. sALINAS, 2011). Os jesuítas julgavam que a proximidade com colonos poderia corromper seu projeto de missionação, preferindo fundar suas Reduções em áreas afastadas: estas no Guayrá, mas também no Chaco, onde não tiveram o mesmo sucesso.

As Reduções foram, em certa medida, uma forma dos Guaranis sobreviverem às radicais mudanças que enfrentavam em seus domínios, mas cabe sempre enfatizar que, na prática, os jesuítas eram partícipes das campanhas de sujeição das populações americanas. Por meio da igreja impunham o domínio simbólico sobre os grupos que incorporavam a seu projeto de evangelização, santificando uma empresa carregada de violência. Ademais, nem sempre os guaranis nas Reduções estavam a salvo das demais mazelas da conquista: não estavam a salvo das encomiendas 
- trabalhavam por dois meses ao ano para encomienderos de Ciudad Real e Villa Rica - e, principalmente, não estavam a salvo das rancheadas e dos ataques de paulistas, conforme nos dá notícia o Padre Jarque,

Quando com mais prosperidade e mais de vento em poupa iam os zelosos missionários, encaminhando aquelas nações ao porto da salvação e sossegados já os alvoroços do cacique Aticaya se ia cada dia ampliando o conhecimento de Cristo; despeitado e furioso o demônio, moveu uma indesejável tempestade, valendo-se de indios feiticeiros e espanhói de Villa Rica del Espíritu Santo e juntamente dos mamelucos do Brasil, que com formados esquadrões volantes assaltaram de repente os povoados das novas reduções, e levaram seu habitantes a miseráveis cativeiros.

(JARQUE, 1900[1661]:243-242 - tradução minha ${ }^{29}$ )

As muitas incursões de mamelucos do Brasil às Reduções, desde seus anos iniciai no Guayrá, fizeram com que a coroa espanhola, interessada em evitar a expansão do território português, permitisse que os guaranis usassem armas de fogo, uma permissão que jamais se repetiu na América colonial. Em 1641 houve uma batalha famosa - e que deixou dois mil mortos-, a Batalha do M’bororé. Armados, os guaranis venceram, às margens do M'bororé, um ataque paulista e a partir de então as ameaças mamelucas diminuem e começa um período de maior estabilidade na região e, consequentemente, de crescimento demográfico. Ao final do Século XVI eram já vinte e dois povoados de guaranis cristianizados, não mais onde havia sido fundada as duas primeiras Reduções, mas em área bem mais ao sul, entre o Rio Paraná, a oeste, e o rio Uruguai, a leste. A maior parte dos povoados estava entre estes dois rios, mas também para leste do rio Uruguai - nas terras conhecidas como "Banda Oriental", que hoje estão no estado do Rio Grande do Sul - havia sete Reduções. O auge populacional das Reduções será na primeira metade do Século XVIII, quando da existência dos "Trinta Povos das Missões", onde veremos funcionar a imprenta guaranítica.

Mas, foi ainda nos anos iniciais, de instabilidade no Guayrá, que chegou al quem seria o maior advogado da imprensa, o jesuíta Antonio Ruiz de Montoya, de Lima. Profícuo escritor, Montoya já chega às Reduções conhecendo a língua guarani. Podemos dizer que este padre é uma das figura símbolo do uso da língua na conquista espiritual, o que estará, nas Reduções Jesuíticas Guarani, como em outras missões jesuíticas mundo a fora, muito articulado ao esforço de escrever e imprimir (Cf. verissimo, 2011) ou, reduzir para escrever e imprimir.

29 Cuando con más prosperidad y más viento en popa iban los celosos misioneros, en-caminando aquellas naciones ápuerto de salvación y sosegados ya los alborotos del cacique Atiguaye se iba cada día dilatando el conocimiento de Cristo; despechado y furioso el demonio, movió una desecha tempestad, valiéndose de indios hechiceros y españoles-de la villa rica del Espiritu Santo, reducciones, ylevaron á sus pobbdores á miserable cautiverio" (Janous, 1900 [1661]:243-242)
Antes de seguir para as Reduções, Montoya passou um período no colégío de Asunción. Duas obras do reitor do colégio, o padre Diego González Holguín, acabavam de ser impressas em Lima: a Gramática y Arte nueva de la lengua general de todo el Perú llamada Qquichua o lengua del Inca, impressa em 1607, e o Vocabulario de la lengua general de todo el Perú llamada lengua Qquichua o del Inca, impressa em 1608. Além das obras de seu próprio reitor, também eram populares no colégio a obra de Ludovico Bertonio, sobre a língua Aymara e, a cima de tudo, o Arte de grammatica da língua mais usada na costa do brasil, do padre Anchieta (Cf. PÉREZ, 1997).

Anchieta ensinava no colégio de São Paulo, naquela outra extremidade da bacia rio-platense. Esta sua gramática da língua tupi havia sido impressa em Coimbra em 1595, mas já circulava 39 anos antes: em 1555 uma cópia manuscrita teria sido entregue para Nóbrega levar à Bahia e desde então, circulava entre missionários para sua instrução na "língua da terra" (DAHER, 1997:35). Não por coincidência, estas obras, tão importantes para os jesuítas de Asunción, tratam de línguas de grande extensão territorial. Gramaticalizadas e dicionarizadas, estas línguas foram transformadas pelos jesuítas em "línguas gerais" a serviço de seu projeto missionário. Alinhados a estas ideias, os padres daquele colégio formavam um grupo convencido da importância e necessidade do estudo das línguas indígenas (MELIÀ, 2002:IX). Quando Montoya chega ali, o ambiente está impregnado de entusiasmo pela língua guarani, que era também uma língua de grande extensão territorial e, por isso, indispensável o seu uso na conquista religiosa do Prata, como o próprio Montoya reconheceu,

"[Língua] Tão universal, que domina ambos mares, o do Sul por todo o Brasil, e rodeando todo o Peru, com os mais grandiosos rios que conhece a Orbe, que são o da Prata, cuja boca em Buenos Aires, é de oitenta léguas, e o Gran Maranhão, a ele inferior em nada, que passa bem vizinho a cidade de Cuzco, oferecendo com suas imensas águas ao mar Do Norte, e passo aos Apostólicos varões combinando-lhos à conversão de inúmeros Gentis desta língua, que esquecidos de sua saúde eterna, vivem à sombra da morte em suas ribeiras."

(MONTOYA apud VERÍssimo, 2011:49 - tradução minha ${ }^{30}$ ).

Na Província do Paraguai o guarani foi a língua assumida pelos jesuítas como língua geral (Cf. melià, 2010). A chegada da Companhia de Jesus ao Prata é, portanto, um marco da redução da língua guarani, um movimento análogo a redução dos povos, "sem redução da língua seria muito difícil a redução social e política; a religiosa, pouco

30 "Lengua] Tan universal, que domina ambos mares, el de Sur por todo el Brasil, y ciñendo todo el Peru, com los dos mas grandiosos ríos que conoce El Orbe, que son el de la Plata, cuya boca en Buenos Ayres, es de ochenta léguas, y el grand Marañon, a el inferior en nada, que passa bien vecino a la ciudad del Cuzco, ofreciendo com sus inmensas aguas al mar Del Norte, y passo a los Apostor ar te la muerte en sus riberas" ( 
menos que impossivel" (MELIÀ, 2002:VI - tradução minha ${ }^{31}$ ). A "redução da língua" se dá quando situações linguísticas complexas são unificadas em representações escritas, procedimento básico de qualquer linguística colonial (ERRINGTON, 2001:19) Feita a gramaticalização e apagamento de diferenças lingüísticas, segundo a norma da língua da igreja católica, a língua indígena reduzida se torna, como as línguas européias vernáculas, uma imagem da língua modelo, o latim (DAHER, 1997:36). Neste procedimento de redução linguística no período colonial, as gramáticas, vocabulários e, também, os catecismo, complementam-se uns aos outros (DAHER, 1997; ADONE, 2007)

Se vimos a lenta expansão das línguas da família tupi-guarani, iniciada na Amazônia, aproximadamente 2000 anos antes, até que os tupinambás chegassem à costa e os guaranis chegassem ao Prata, vemos agora estas duas línguas se encontrarem como parte de outra expansão territorial, a da escrita latina. Muito articulada a expansão do cristianismo, a escrita latina, coincidentemente, também começou a espraiar-se pelo mundo aproximadamente 2000 anos antes (COULMAS, 2003:197) que fossem escritas as primeiras letras em língua guarani ${ }^{32}$ e que Montoya imprimisse, pela primeira vez, nesta língua: em 1639 este padre publica o Tesoro de la lengua Guarani e, um ano depois, mais duas obras, justamente um vocabulário - Arte y Vocabulario de la lengua guarani - e um catecismo - Catecismo en lengua guarani. Todas foram impressas em Madrid, antes dos tempos de mais tranquilidade que permitiram a instalação da imprensa no Prata.

\section{O DESENHO DAS LETRAS RIO-PLATENSES}

\subsection{O DESENHO DAS LETRAS MANUSCRITAS}

As belas letras de molde - letras não-cursivas, desenhadas uma por uma em semelhança às letras impressas - copiadas à mão nas Reduções foram celebradas pelos jesuítas como resultado do sucesso de sua missão. Os relatos referem-se não aos bilhetes, cartas e documentos manuscritos - como aqueles produzidos durante a Guerra Guaranítica, quando da expulsão dos Jesuítas do Prata (Cf. NEumann, 2005) —, mas a livros inteiros copiados à mão.

Não se sabe ao certo o número de manuscritos desse tipo nem tampouco como eram produzidos, se eram copiados em série, se eram copiados a várias mãos e quais manuscritos teriam sido mesmo produzidos nas Reduções, já que é possível que alguns tenham sido trazidos da Europa, onde também era comum nesta época que livros inteiros fossem copiados à mão (Cf. BOUZA, 2001).

$\mathrm{Na}$ tentativa de confrontar o relato sobre a perfeição da cópia da letra nos manuscritos guaraníticos com os próprios manuscritos, analisamos as letras em três deles:

Catecismo de la lengua guarani [...]. 1640

Edvcacion christiana: y buena criança de los niños guaranis [...]. 1713

Ordo baptismi parvulorum [...]. 16--

São três manuscritos muito diferentes entre si. O Catecismo de la lengua guarani [...] é um manuscrito copiado segundo um modelo, assim, começamos a análise por ele, pois a referência do modelo ressalta as peculiaridades da cópia. O Edvcacion christiana [...] é um manuscrito que só existe em forma manuscrita, não há modelo para ele, que se conheça. Entretanto, há algo comum aos dois livros: Na folha de rosto as letras são desenhadas para parecerem-se com letras "de molde", enquanto no miolo as letras são cursivas. Aqui analiso apenas as letras nas folhas de rosto. O Ordo baptismi [...] é todo em "letra de molde", inclusive o miolo. Deste analiso apenas algumas letras, selecionadas da folha de rosto.

32 A escrita latina teve um percurso próprio até o Prata. Chegou antes em outras partes da América, bastante ao norte da 
Em primeiro lugar, analisei as letras na folha de rosto do Catecismo de la lengua guarani (мотоун, 1640) impresso em Madrid em 1640, ou seja, o livro que serviu de modelo [FIGURA 1 1 P 42] para a cópia manuscrita [FIGURA 2 $\cdot$ P 43] posteriormente realizada nas Reduções. O objetivo foi traçar características gerais do desenho dos caracteres na folha de rosto do modelo impresso para então verificar a correspondência destas características na cópia manuscrita do Catecismo. A análise baseia-se, em grande parte, na abordagem para descrição de formas tipográficas modelo proposta por Dixon, conforme apresentado em Type \& typography (BAINEs e HASLAM, 2005:50-58), mas também faz referência à classificação por termos históricos defendida por Bringhurst, como apresentado em Elementos do estilo tipográfico (BRINGHURST, 2005:133-158).

As informações na folha de rosto são: título completo da obra, incluindo nome do autor, sua filiação à Companhia de Jesus e dedicação à Virgem Maria; indicação de licença para imprimir; local de impressão; e data de impressão.

O texto está alinhado ao centro da página. Há uso de caracteres tipográficos em três tamanhos diferentes no estilo romano e dois tamanhos diferentes em itálico. Percebe-se o uso de caracteres itálicos e romanos em uma mesma linha (na linha que indica o local de impressão), o que é apontado por Bringhurst (2005:140) como uma característica da composição tipográfica barroca. No centro da metade inferior da página há uma gravura com o símbolo da Companhia de Jesus. A impressão é toda na cor negra.

Os caracteres romanos na folha de rosto do Catecismo têm a altura-x generosa as ascendentes maiores que as descendentes e as maiúsculas ligeiramente menores que as ascendentes. Os caracteres itálicos têm a mesma altura- $\mathrm{x}$ que os caracteres romanos. A altura das ascendentes e das maiúscula também coincide, mas as descendentes são maiores, têm o mesmo tamanho de suas ascendentes [FIGURA 3].

Os caracteres romanos podem ser descritos como de construção contínua e traço modulado. O contraste entre traços grossos e finos é moderado, a transição entre eles é suave e o eixo de contraste é inclinado para a esquerda, mas há um eixo secundário vertical, o que é novamente apontado como uma característica de formas tipográficas barrocas (BRINGHURST, 2005:141). As aberturas são moderadas,

FIGURA 3 - Catecismo impresso roporção dos caracteres rong

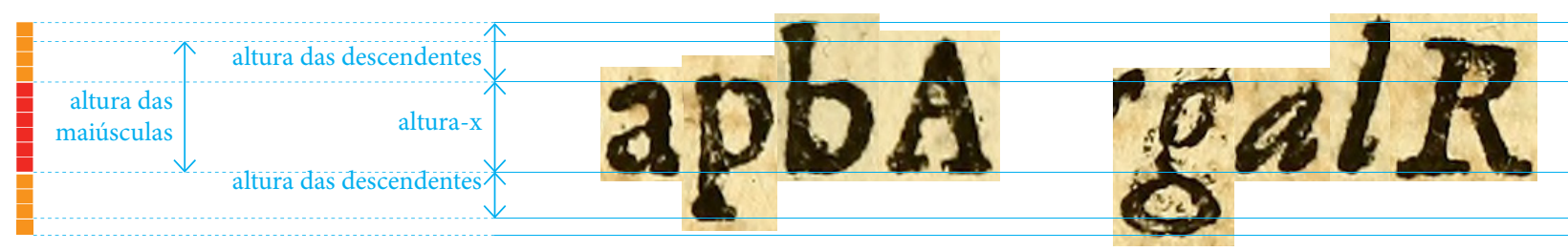

os terminais suavizados em forma de lágrima (não são gotas exageradamente redondas, mas já não são terminais abruptos como nos primeiros tipos renascentistas). As serifas de base são bilaterais, chatas e adnatas (a transição da haste para a serifa não é completamente abrupta) e as serifas de topo são oblíquas e aproximam-se da forma de cunha, já não são completamente bem definidas e inclinadas e afastam-se das formas caligráficas [FIGURA 4].

Há ainda alguns caracteres-chave que podem ser observados: o e minúsculo tem barra horizontal; o $\mathbf{P}$ maiúsculo tem uma abertura no bojo; o $\mathbf{R}$ tem a perna reta; o vértice do $\mathbf{A}$ é oblíquo e levemente côncavo e, assim como os terminais de $\mathbf{C} \mathrm{e}$ T, faz referência mais aos instrumentos de gravação de tipos em metal do que à pena [FIGURA 5]. Estas características são parte do padrão das romanas aldinas, segundo o sistema para descrição de tipos proposto por Dixon (BAINES E HASLAM, 2005:64) e do estilo barroco, conforme classificação de Bringhurst (BRINGHURST, 2005: 141-142).

Nos caracteres itálicos, o eixo de inclinação varia de um caractere para o outro, assim como o eixo de contraste é ambidestro: em caracteres como c e e minúsculos é inclinado para a esquerda e no o minúsculo é inclinado para a direita [FIGURA 6] - esta também é uma característica dos tipos barrocos (BRINGHURST, 2005:140) -; As terminais são suaves, em forma de lágrima e as serifas de topo derivam de forma caligráfica, mas com corte enfático. As serifas de base são bilaterais, relativamente finas e adnatas (estão suavemente apoiadas à haste por uma curva) e os arremates das itálicas derivam claramente de formas caligráficas [FIGURA 7].

FIGURA $4-$ Catecismo impresso

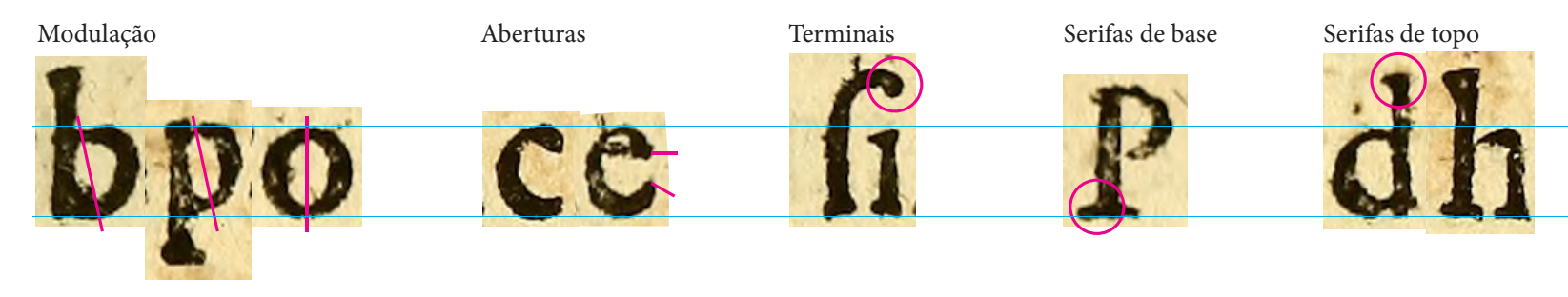

FIGURA 5 - Catecismo impresso Caracteres-chave FIGURA 6 - Catecismo impresso ePRAGT dlm éo FIGURA 7 -Catecismo impresso grdim 


\section{CATECISMO}

\section{DE LA LENGVA}

GVARANI, COMPVESTO por el Padre Antonio Ruyz dela Compañia de Ielus.

Dedicado a la purifsima Virgem $M A R I A$ :

Con cebida fin mancha depecá do original.

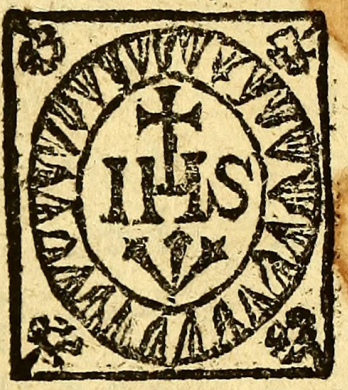

$\frac{\text { CON L ICENCIA }}{\text { En Madrid,Por Diego Diax dela Gurrés? }}$ ARिQ M. DC. XXXX:

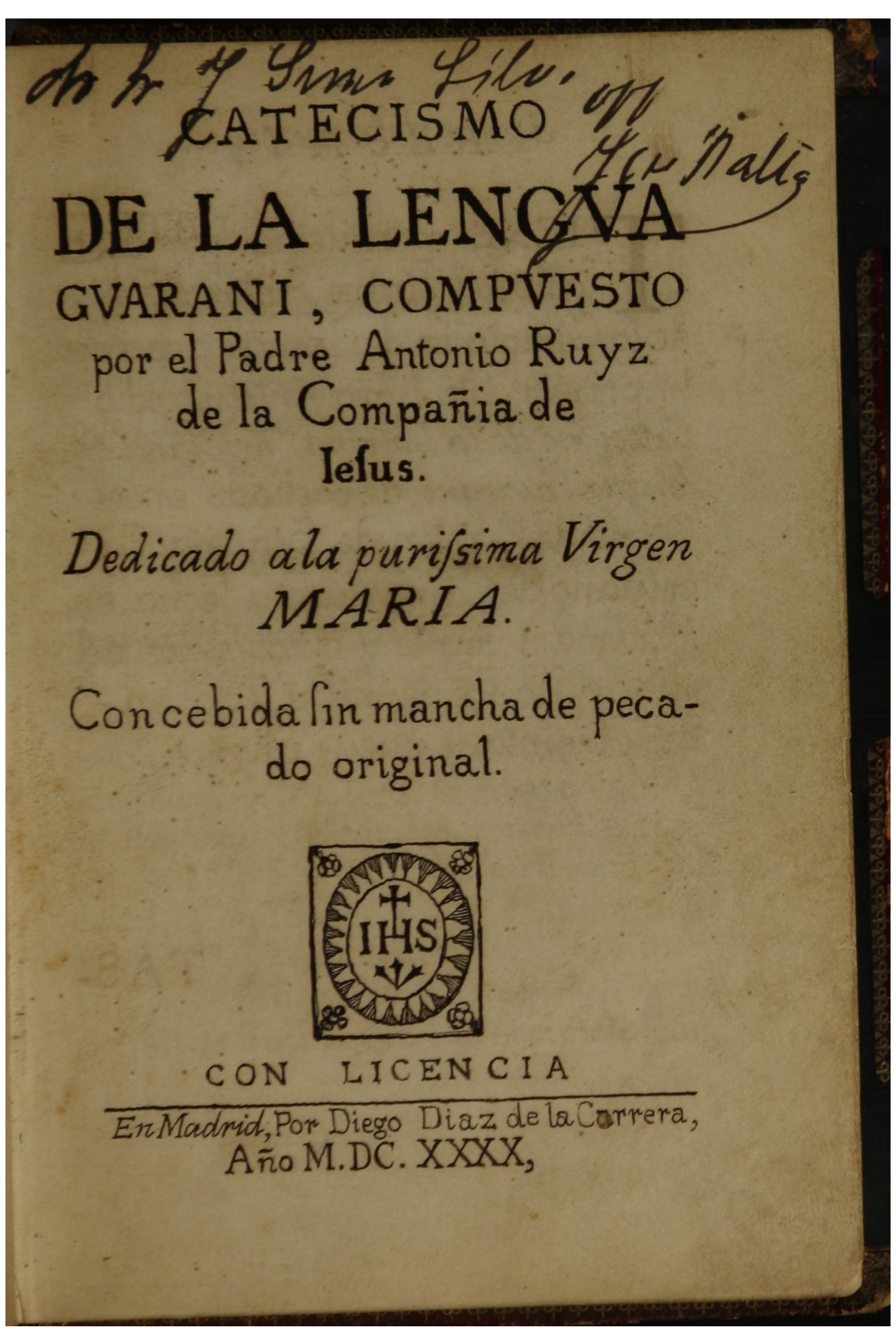


Na folha de rosto da cópia à mão do Catecismo (1640) [FIGURA 8 • PP 46-47], observa-se que as informações são as mesmas daquela no Catecismo impresso.

O alinhamento do texto, disposição dos elementos na página, tamanho e estilo dos caracteres também se repetem em relação à folha de rosto impressa.

Quanto ao tamanho e proporções internas dos caracteres, observa-se que a altura-x dos estilos romanos e itálicos é, em geral, a mesma no Catecismo manuscrito e no Catecismo impresso. Mas a altura das ascendentes e descendentes varia muito de um caractere para o outro, tanto nos caracteres romanos quanto nos caracteres itálicos [FIGURA 9]. O mesmo ocorre com a altura das maiúsculas: são maiores no manuscrito e variam de um caractere para outro [FIGURA 10].

Na cópia manuscrita os caracteres romanos têm abertura moderada, como na versão impressa. A forma dos terminais varia, mas observa-se a predominância da forma lacrimal, como no Catecismo impresso [FIGURA 11]. Há grande variedade na forma das serifas de base, algumas quadradas e abruptas (sem uma curva que suavize a junção entre haste e serifa), outras com formas derivadas da caligrafia. Nem todas são bilaterais, como no modelo impresso, e em alguns caracteres há mesmo ausência de serifas. [FIGURA 12].

Há também grande variedade na forma das serifas de topo. Algumas oblíquas, outras retas, algumas adnatas outras abruptas. Em alguns caracteres a serifa é quase imperceptível e, em ao menos um deles, aparece na forma de gancho [FIGURA 13]. Quanto à modulação, na cópia manuscrita o traço dos caracteres também é modulado, sem interrupções abruptas entre traços grossos e finos. O contraste entre traços grossos e finos varia bastante de um caractere para o outro: em alguns é muito nítido, em outros quase imperceptível, o que dificulta a definição de um eixo de contraste [FIGURA 14].

Em relação aos caracteres-chave, observa-se algumas diferenças na cópia manuscrita do Catecismo: variações na inclinação da barra do e, que não é sempre

FIGURA 9 Catecismo manuscrito Proporções dos caracteres romanos e itálicos.
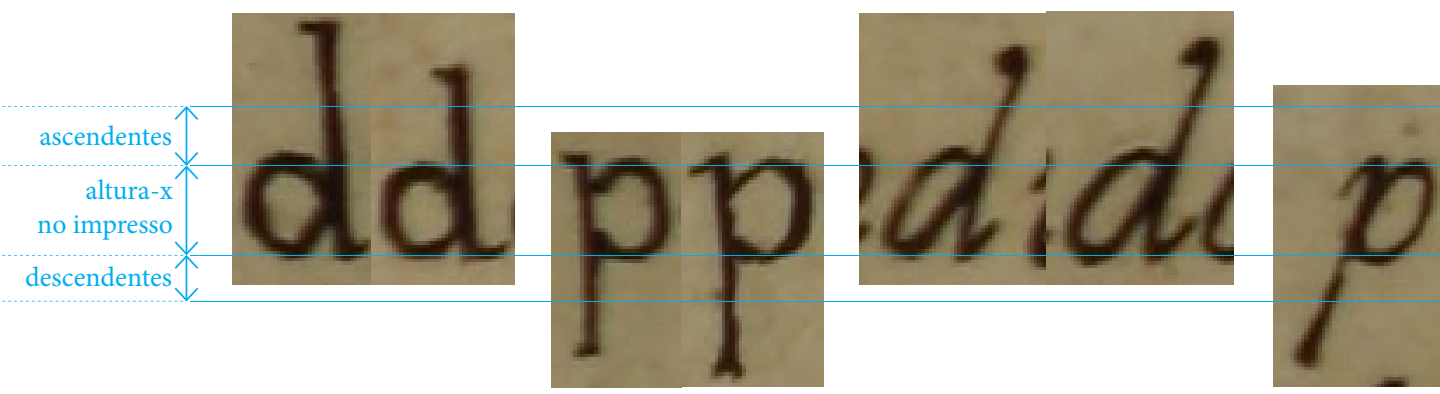

IGURA 10

Catecismo manuscrito

Altura das maiúsculas romanas e itálicas.

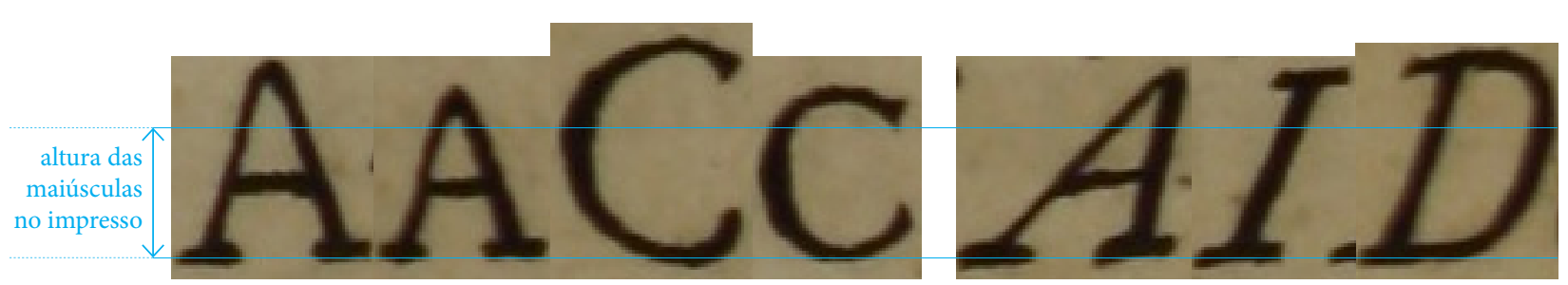

FIGURA 11

Catecismo manuscrito

Aberturas e terminais nos caracteres romanos.

ce ccceeeeeee

$\int_{1}^{1}$

FIGURA 12

Catecismo manuscrito

Serifas de base nos caracteres romanos.

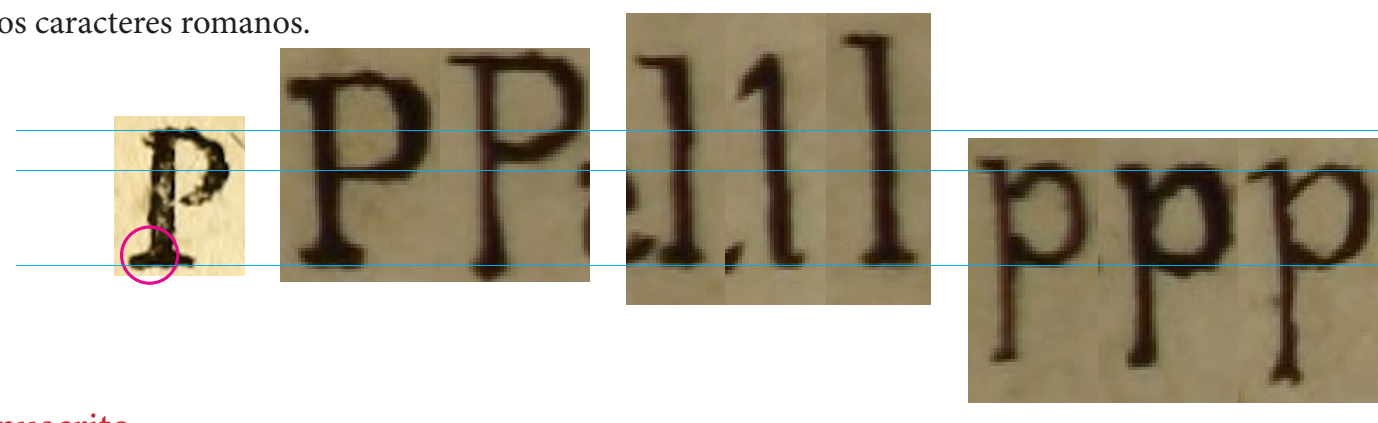

FIGURA 13

Catecismo manuscrito

Serifas de topo nos caracteres romanos.

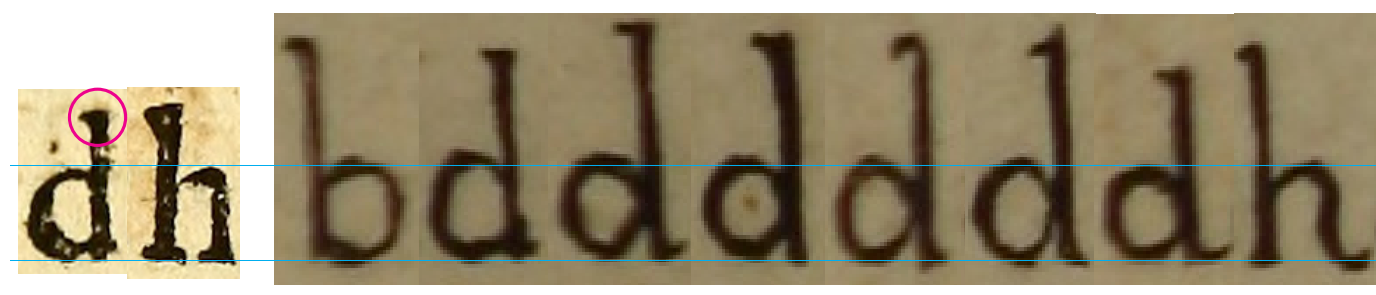

FIGURA 14

Catecismo manuscrito

Modulação e eixo de contraste.

00000000 


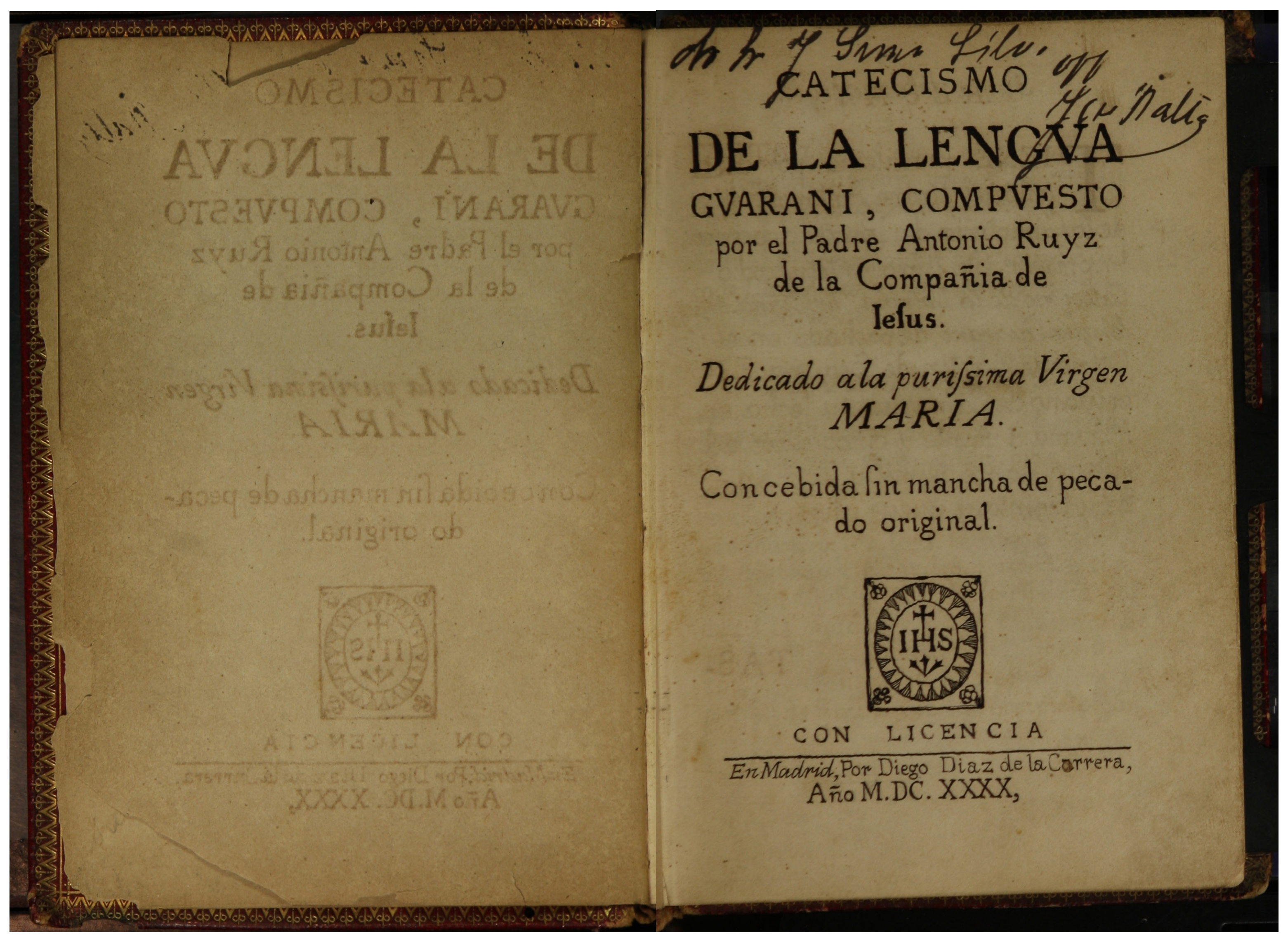


horizontal como no impresso; o bojo do $\mathbf{P}$ é fechado; o terminal do $\mathbf{C}$ tem forma mais suave, derivada da caligrafia, com menos referência aos instrumentos de gravação; a perna do $\mathbf{R}$ é curva; e o vértice do A é arqueado e pouco definido. [FIGURA 15].

De modo geral, pode-se dizer que enquanto algumas características dos desenhos de caracteres na folha de rosto do Catecismo impresso e em sua cópia manuscrita são radicalmente diferentes - como a proporção entre as alturas-X, ascendentes e descendentes - , há outras que mantêm-se iguais - como os terminais em forma de lágrima e a modulação com pouco contraste entre traços grossos e finos.

Entretanto, algumas diferenças merecem maior atenção. A grande variedade de serifas de topo e de base aponta para um retorno às formas manuscritas e, ainda que pareça óbvio dizer que um livro copiado à mão realize um trajeto de retorno às formas manuscritas, chama atenção que este "retorno" se dê de forma tão variada e não consistente: não há uma diferença que se repita em relação ao modelo impresso, mas uma variedade de novas formas. Mais do que a diferença entre o modelo impresso e a cópia manuscrita, chama atenção a inconstância nas formas encontradas no manuscrito

Talvez esta inconstância se dê justamente pela falta de uma tradição caligráfica O "retorno" parece ao mesmo tempo intuitivo - a serifa em forma de gancho poderia apontar o movimento natural da mão do copista - e preso a uma camisa de força: o modelo a ser copiado.

FIGURA $15-$ Catecismo manuscrito
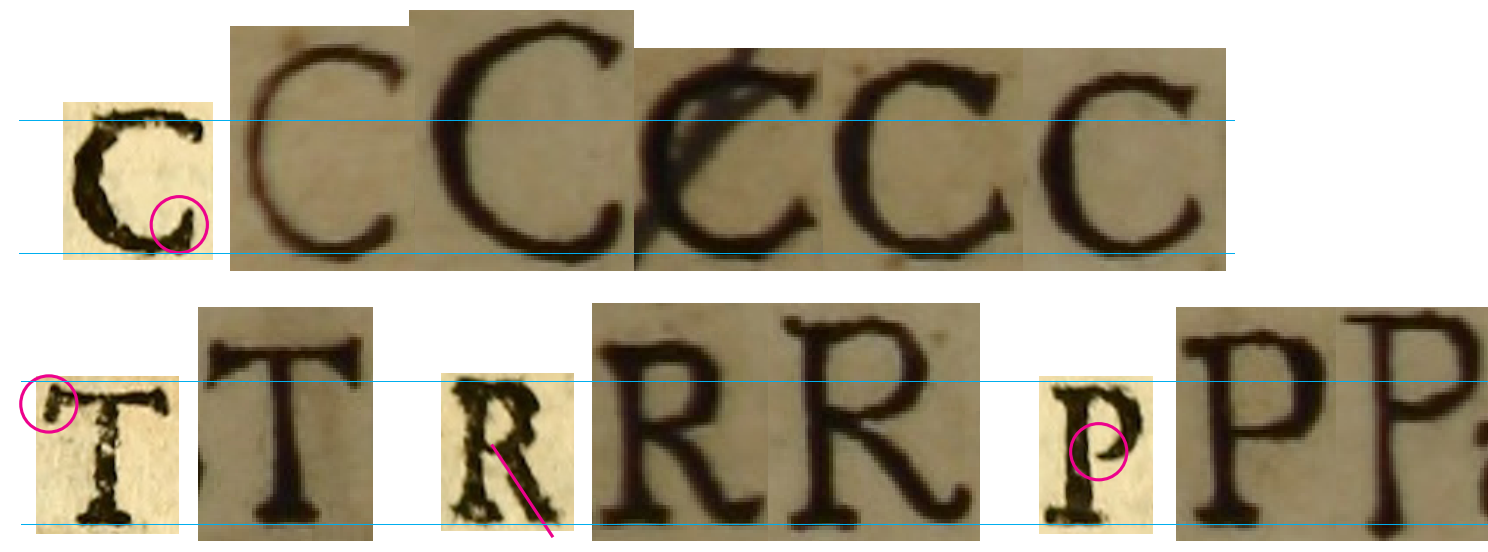

e eeeeeeee

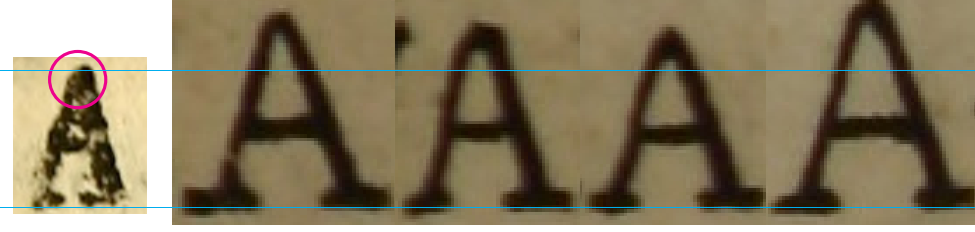

Caracteres-chave
2.1.2 Manuscrito sem modelo: Edvcacion christiana: y buena criança de los niños guaranis [...]. 1713

No Edvcacion, como no Catecismo, as letras "de molde" estão na folhas de rosto. São duas: a primeira com título em espanhol [FIGURA $16 \cdot$ PP 50-51], a segunda com título em guarani. Não se conhece outro exemplar deste manuscrito, nem um correspondente impresso, conforme consta em sua ficha catalográfica, na biblioteca John Carter Brown. Portanto, para este manuscrito não há um modelo impresso com o qual compará-lo.

Vemos na folha de rosto letras de quatro tamanhos tamanhos [FIGURA 17]. Os tamanhos médios vêm acompanhados de minúsculas [FIGURA 18], nos tamanhos menor e maior aparecem apenas as maiúsculas.

A altura-x é bastante ampla, as descendentes são curtas e as ascendentes são mais altas que as maiúsculas. A altura das ascendentes e descendentes mantêm-se, $\mathrm{e}$ quando vemos alguma variação ela se dá na altura-X [FIGURA 19], principalmente nas últimas letras de uma mesma linha: vemos o condensamento das letras e do espaço entre elas, para fazer caber o texto. É o que se vê na linha onde está escrito "Para alcançar perseverancia final y una buena". Assim, se no Catecismo a altura das ascendentes era muito inconstante, aqui a inconstância se vê mais na altura-x.
FIGURAS $17-$ Edvcacion

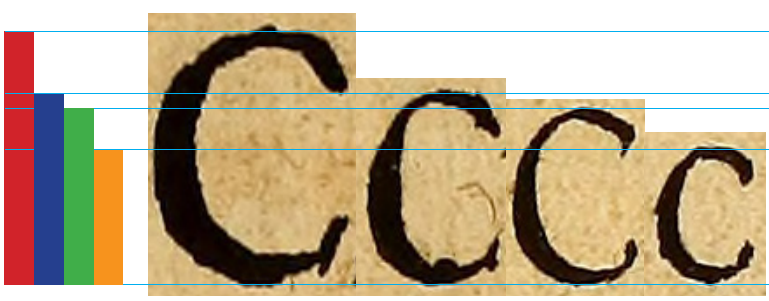

Quatro tamanhos de caracteres maiúsculos.
FIGURAS $18-$ Edvcacion

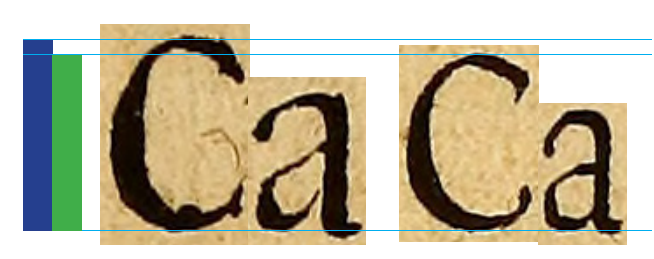

Tamanhos médios acompanhos de minúsculas.
FIGURA $19-$ Edvcacion

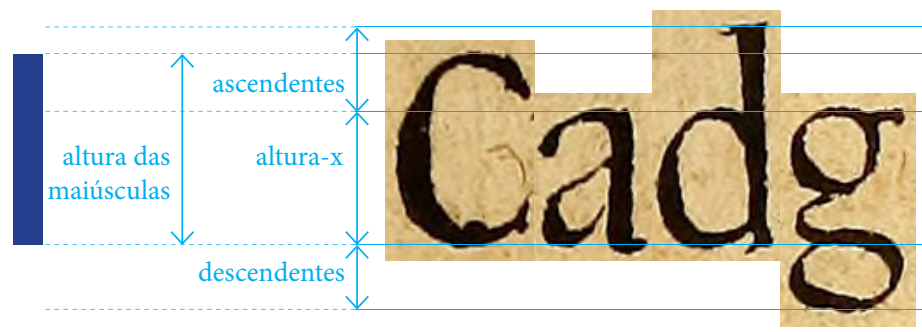

Proporção interna dos caracteres. 
FIGURA16 - Edvcacion Folha de rosto.

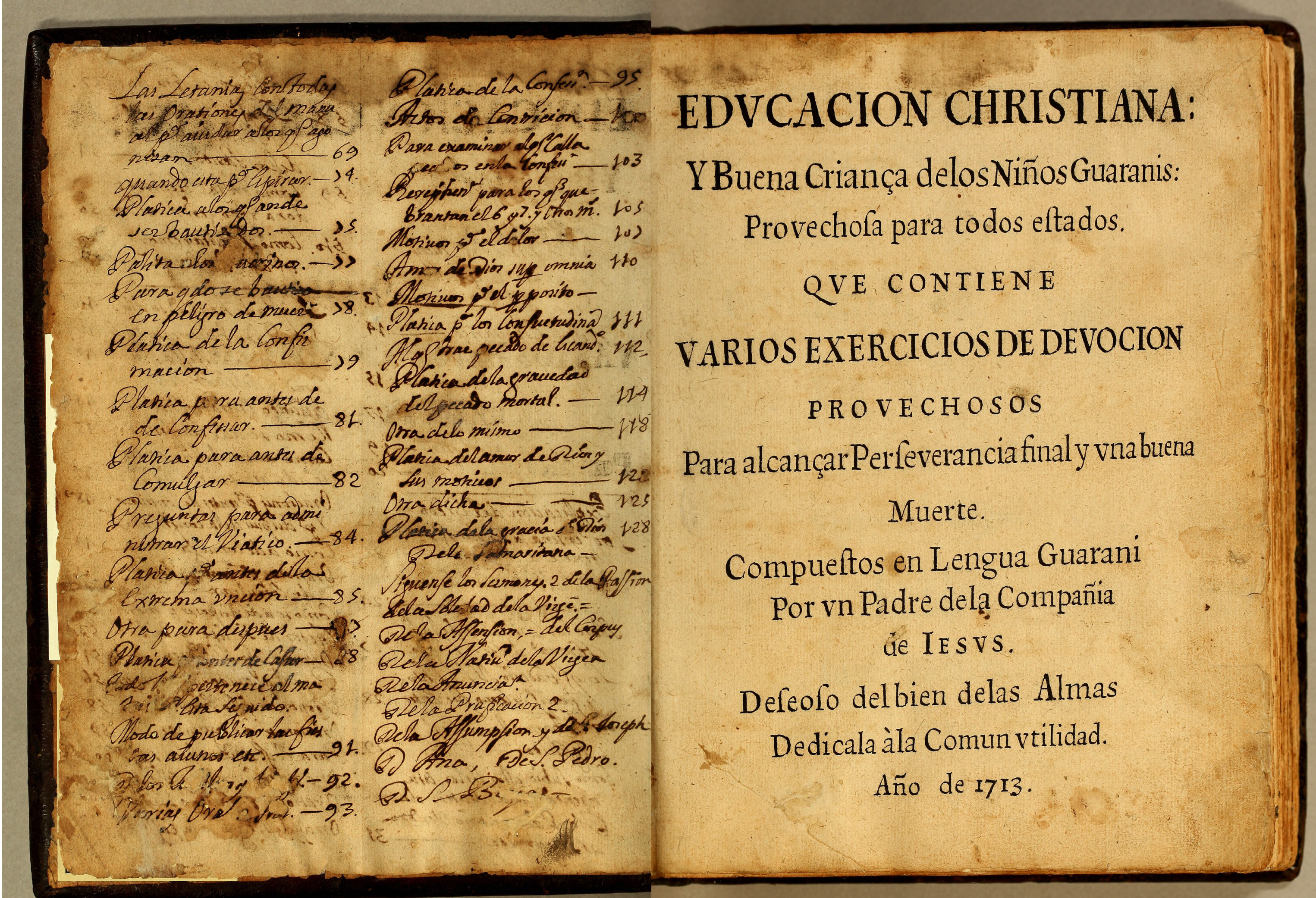


A modulação do traço e eixo de contraste das letras minúsculas do Edvcacion são bastante nítidos, o que, geralmente, é resultado do uso de pena chata. Os terminais, serifas de base, serifas de topo e arremate todos transparecem movimentos caligráficos, feitos com uma pena [FIGURA 20].

Nas maiúsculas, como nas minúsculas, os traços - grossos e finos, alternados de acordo com a direção da pena - e as serifas - cuidadosamente acrescentadas às extremidades das letras -, testemunham a familiaridade com técnicas de caligrafia das letras humanistas [FIGURA 21]. O conhecimento desta técnica fica ainda mais nítido no $\mathbf{Q}$ maiúsculo, cuja cauda, longa, está traçada com bastante precisão, na ligadura ft e em um a minúsculo com arremate decorativo [FIGURA 22]. caligráfica, ou seja, o desenho das letras transparecia o manejo intuitivo da pena,
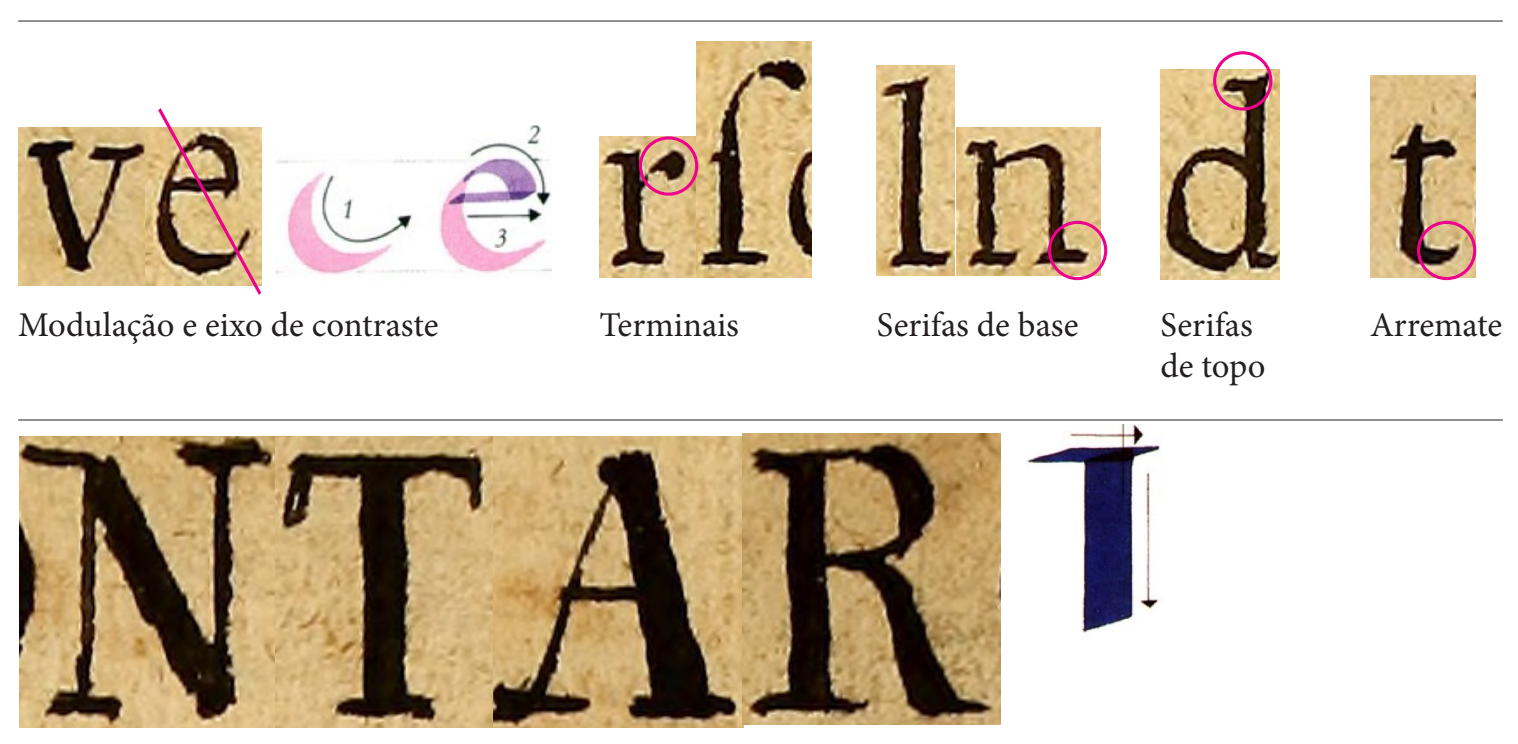

IGURA 20

Edvcacion

Serifas e tratamento do traço nas maiúsculas.

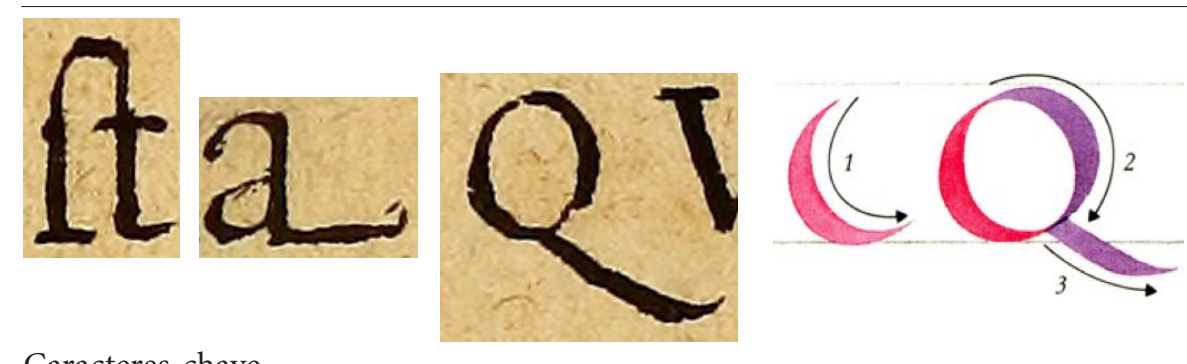

Caracteres-chave

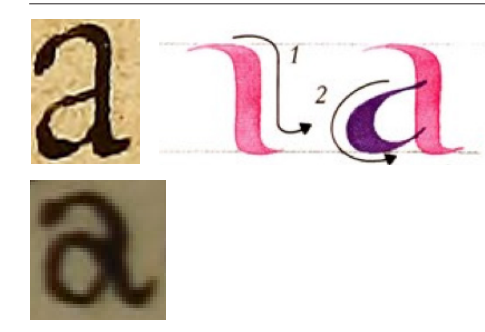

FIGURA 23

Edvcacion

Catecismo
Se nas letras do Catecismo manuscrito estava marcada uma falta de tradição

esforçando-se para seguir o modelo impresso, mas escapando em um "retorno" às formas manuscritas, no Edvcacion as letras são fluentes, desenhadas sem um modelo impresso, mas com manejo treinado da pena. Esta afirmação só é possível observando os caracteres em detalhe, vê-se, por exemplo, que nos a's minúsculos do Edvcacion os bojos foram desenhados com traços separados, como manda a caligrafia humanista, enquanto no Catecismo os a's são desenhados com um único traço, sendo o bojo um "laço", ou uma "volta" do traço [FIGURA 23].

2.1.3. As belas letras do Ordo baptismi Parvulorum [...]. 16--

As letras negras e vermelhas do Ordo [FIGURA 24 - PP 54-55] aparecem em dois tamanhos, têm altura-x proporcionalmente maior do que as que vimos antes, as ascendentes são curtas e as descendentes ainda mais curtas, as maiúsculas têm a mesma altura das ascendentes [FIGURA 25]. As letras são largas e de contra-formas claras, menos condensadas que as letras do Edvcacion. Como naquele livro, vê-se pela modulação e contraste marcado entre traços grossos e finos a familiaridade com a pena e com técnicas de caligrafia. O mesmo pode ser observado nos detalhes: terminais, serifas e arremates, em formas derivadas das pena [FIGURA 26]. O $\mathrm{Q}$ maiúsculo e algumas ligaduras são também testemunha do uso da pena e de um desenho feito com bastante precisão[FIGURA 27].
FIGURA 25

Ordo

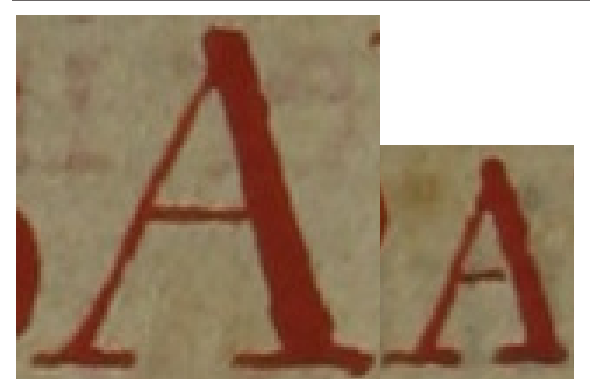

Dois tamanhos

FIGURA 26

Ordo

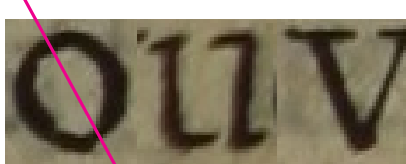

Modulação e contraste

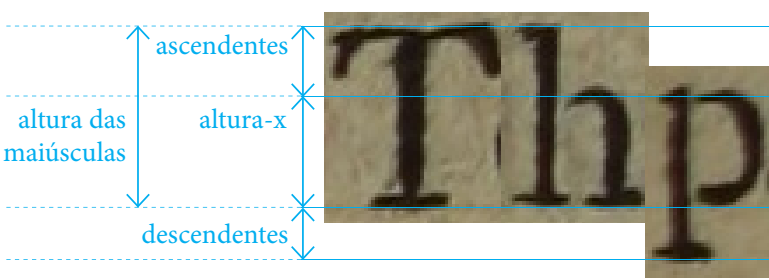

Proporção interna dos caracteres.
FIGURA 27

Ordo

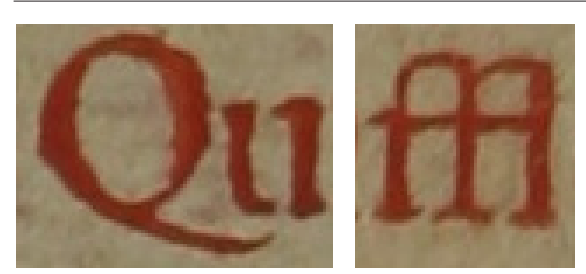

Q e ffl no Ordo.

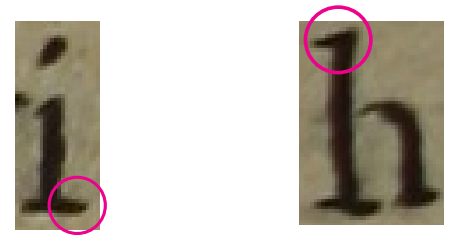

Serifas de base
Serifas de topo

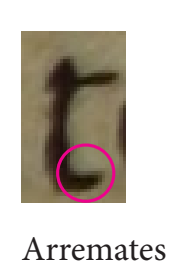




\section{ORDOBAPTIS}

\section{PARVVLORVM.}

Preguntas enla Lengua Guarani para Baptizar Quid petis \& ic.

P. Mbaerehe pânga ereyerure $S$. $^{\text {ta }}$ Madre Iglefia vpe rae? vel. peyerure. R. Iefu Chrifto rero bia habarehe.

P. Iefu Chrifto rerobia habamba è pângå omeêndeberae? vel. Omeê peê mene. R. Teco horì apirreỹma.

Sacerdos. Siigitur vis ad vitam ingredi, ferua mandata : Diliges Dominum Deum tuum ex toto corde tuo , \& extota anima tua, \& ex tota mente tua, \& proximum tuum ficut te ipfum. Deindeter ex fufflet 
Se comparadas as letras nas folhas de rosto dos três livros manuscritos, percebemos que as letras do Edvcacion e do Ordo são mais parecidas, por manterem o contraste entre traços grossos finos, e uma certa modularidade do desenho, feito sempre com mais de um traço da pena e transparecendo intimidade com a técnica, enquanto as letras do Catecismo são distintas, com pouco contraste entre traço grossos e finos. Para visualização deste aspecto, a comparação dos a's minúsculos é particularmente interessante [FIGURA 28]: no Edvcacion e no Ordo, percebemos que o a foi construído com, pelo menos, dois traços e no Catecismo o a é desenhado com um único traço. Em vários caracteres do Ordo as interrupções nos traços são bastante nítidas, como em $\mathbf{h} \cdot \mathbf{u} \cdot \mathbf{r}$ [FIGURA 29].

A modularidade e constância na construção das letras nas folhas de rosto do Ordo e do Edvcacion dão a elas um aspecto bastante homogêneo, o que não significa que não haja variações nos desenhos. Observando os d's minúsculos, por exemplo, vemos uma pequena variação na espessura das hastes [FIGURA 30].

Entretanto, são variações muito sutis. A homogeneidade do texto surpreende muito no Ordo pois neste livro as letras são "de molde" na folha de rosto e também

\section{aаa}

GURA 28 Edvcacion

Comparação de a's minúsculos.

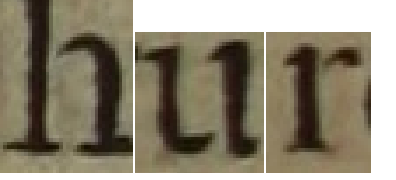

h, u e r minúsculos, no Ordo.

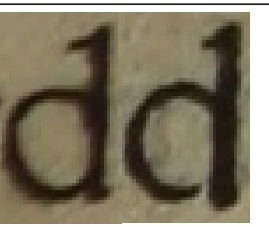

d's minúsculos.

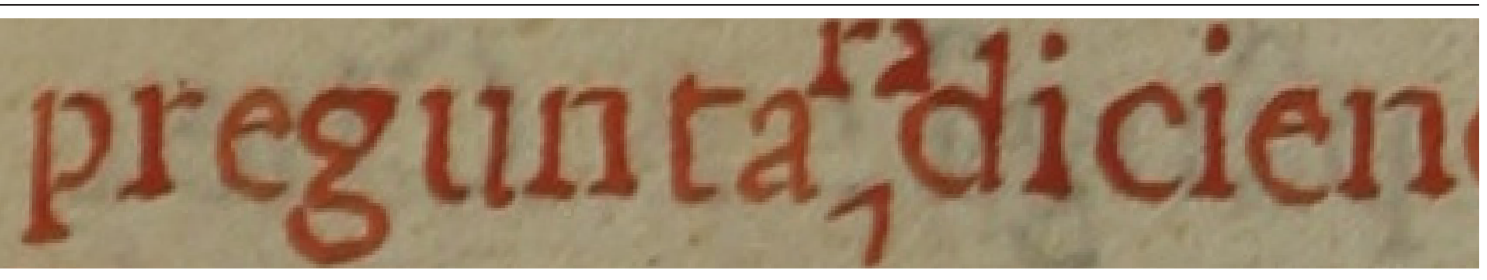

IGURA 31 no miolo. Mesmo as correções no texto são feitas de forma bastente cuidadosa, com letras desenhadas à semelhança das demais [FIGURA 31].

$\sim$

Não se sabe ao certo quais destes livros foram mesmo manuscritos nas Reduções, mas sabemos que circulavam por lá. Assim, consideramos os três como "manuscritos guaraníticos", objetos do discurso sobre a qualidade das letras "de molde" desenhadas pelos "habilidosos copistas guaranis". O que percebemos, entretanto, é justamente a variedade de desenhos de letras na folha de rosto de cada uma das três folhas de rosto, o que aponta para diferentes domínios da pena - algumas vezes mais fluente, como no Ordo e no Edvcacion, outras menos, como no Catecismo - e para diferentes abordagens na produção dos manuscritos - ora seguindo um modelo impresso, ora não.

Quanto às inconstâncias nos desenhos das serifas, altura-x e altura das ascendentes, presentes num mesmo livro, é esperado encontrá-las em letras manuscritas, afinal o processo não é mecânico. Já nas impressas, algumas inconstâncias são surpreendentes, como veremos, pois trazem à tona questões sobre a produção de tipos nas missões.

\subsection{O DESENHO DAS LETRAS IMPRESSAS}

Dos doze livros e um tanto de panfletos que certamente foram impressos nas missões rio-platenses, é possível localizar exemplares de oito ${ }^{33}$, são eles:

\section{Três impressos em Loreto:}

De la diferencia entre lo temporal y lo eterno [...]. 1705

Instruccion practica para ordenar santamente la vida [...]. 1713

Manuale ad usum patrum [...]. 1721

Três impressos em Santa Maria la Mayor:

Vocabulario de la lengua guarani [...]. 1722

Arte de la lengua guarani [...]. 1724

Explicacion de el catechismo en lengua guarani [...]. 1724

E dois impressos em São Francisco Xavier:

Sermones y exemplos en lengua guarani [...]. 1727

Carta que el señor doctor Jose de Antequera y Castro [...]. 1727 
A quantidade de exemplares restantes por título varia. Do Arte de la lengua guaran [...] há treze exemplares enquanto que do Manuale ad usum patrum [...] e do Carto que el señor doctor Jose de Antequera y Castro [...] resta apenas um exemplar. Os exemplares restantes estão quase todos em bibliotecas públicas ou universitárias, na Europa, nos Estados Unidos, Argentina, Chile e Brasil, e podem ser localizados nos catálogos online das bibliotecas. Pelo menos 6 títulos estão disponíveis na íntegra na internet. ${ }^{34}$

A comparação de exemplares de um mesmo título revela muito sobre o modo de funcionamento da imprensa nas missões. Sabe-se, por exemplo, que os livros eram corrigidos durante prováveis pausas entre a impressão de um e outro exemplar e que os exemplares errados não eram descartados, o que parece confirmar a escassez de recursos, em particular o papel, para a impressão dos livros (Cf. veríssimo, 2011).

A comparação de exemplares de títulos diversos também é reveladora. Assim observou-se que gravuras ornamentais do De la diferencia entre lo temporal y lo eterno [...], impresso em $1705 \mathrm{em}$ Loreto, foram utilizadas em livros impressos em Santa Maria la Mayor, 19 anos depois. Esta observação, somada à verificação das datas de impressão dos livros, leva a desconfiança de que não havia imprensas funcionando simultaneamente em uma e outra Redução, mas que a imprensa mudou-se de uma redução para outra. É o que indicam Guillermo Furlong (1953), Josefina Pla (1975) e, mais rescentemente, Fernanda Veríssimo (2011).

Neste trabalho analisei comparativamente as formas das letras em seis obras diferentes, procedentes da Biblioteca Brasiliana Guita e José Mindlin (Universidade de São Paulo, Brasil), e da John Carter Brown Library (Brown University, Provedence, EUA) $)^{35}$. São eles:

\section{Dois livros impressos em Loreto:}

Instruccion practica para ordenar santamente la vida [...]. 1713

Manuale ad usum patrum [...]. 1721

\section{Três livros impressos em Santa Maria la Mayor:}

Vocabulario de la lengua guarani [...]. 1722

Arte de la lengua guarani [...]. 1724

Explicacion de el catechismo en lengua guarani [...]. 1724

\section{E um livro impresso em São Francisco Xavier:}

Sermones y exemplos en lengua guarani [...]. 1727

34 A localização dos livros na internet pode ser consultada em anexo (ANEXO 2).

35 Informações completas de procedência dos exemplares analisados podem ser consultada em anexo (ANEXO 2).
Dois títulos ficaram de fora das análises, o mais antigo deles, De la diferencia entre lo temporal y lo eterno [...] (1705), impresso em Loreto; e o mais novo, Carta que el señor doctor Jose de Antequera y Castro [...] (1727), impresso em São Francisco Xavier.

Destes, fiz apenas a análise preliminar de algumas páginas, reproduzidas em tons de cinza no Historia y biliografia de las primeras imprentas rio-platenses (17001850), de Furlong (1953). ${ }^{36}$

Do De la diferencia entre lo temporal y lo eterno [...], pude ver a reprodução de várias páginas. Este livro é definitivamente muito distinto de todos os livros impressos depois dele, pois é o único ilustrado, como celebrou Furlong,

Lo singularíssimo de este peregrino libro de la diferencia entre lo temporal y lo eterno [...] son sus muchas y preciocísimas láminas, magistralmente diseñadas y grabadas. Contiene sesenta y siete viñetas, xilográficas en sua mayoría, y contiene además cuarenta y tres láminas.

(FURLONG, 1953a:321)

Além das gravuras, a folha de rosto também torna este livro único, por sua composição clara, regular e, a cima de tudo, esforçadamente alinhada. Os caracteres, quase todos maiúsculos e não maiores do que hoje medimos como 30 pontos $^{37}$, estão bem assentados na linha de base - o que não será uma constante na imprensa guaranítica $^{38}$ - e espaçados de forma a ocuparem por inteiro cada linha da mancha de texto. Quase não se vê o espaçamento entre palavras. O que fica evidente são linhas contínuas, completas de caracteres por toda sua extensão. Uma moldura ornamental delimita com rigor o espaço destinado ao texto e as margens da página.

Esta moldura, bem como o preenchimento completo das linhas na folha de rosto jamais se repetirá na produção livreira guaranítica. Cada um dos livros impressos tem sua singularidade, mas o que predominará depois da impressão desta obra inaugural, pelo menos nos guaraníticos que chegaram aos dias de hoje, é o uso de letras grandes nas folhas de rosto. Há letras grandes neste livro, são nove capitulares

Nesta dissertação reproduzo apenas fotos de livros guaraníticos, ou parte delas, disponibilizadas na internet pelas próprias instituiçōes que guardam os exemplares consultados (John Carter Brown Library e Biblioteca Brasiliana Guita e José Mindlin . que el señor doctor Jose de Antequera y Castro [ ] não reproduzo imagens destes livros aqui .

37 Usaremos em todo o texto as medidas em pontos utilizadas hoje em dia, com o intuito de oferecer ao leitor e à leitora uma idéia melhor do tamanho dos tipos. A unidade mínima de medida tipográica, segundo o sistema atual - o que vemos em programas de editoração de textos - é iponto, que equivale a $1 / 12$ pica e a o,3527 mm

38 Nesta dissertação não analisei a composição tipográíca dos livros, mas apenas o desenho das letras. Entretanto, é possivel

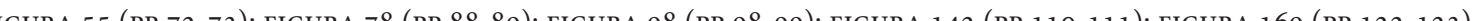


no miolo, entretanto são gravuras, e não tipos, portanto não serão matéria de nossas análises mais detidas.

Uma análise dos tipos utilizados no De la diferencia entre lo temporal y lo eterno [...] certamente enriqueceria $o$ trabalho, mas infelizmente não tive acesso aos dois exemplares deste livro, que podem ser localizados ambos em bibliotecas na Argentina. Entretanto, apesar de muito particular na composição da folha de rosto, nas ilustrações, capitulares gravadas, e na qualidade da composição tipográfica e da impressão, este livro não se distingue dos demais em relação ao desenho dos tipos utilizados no miolo e na folha de rosto. Além disso, veremos mais adiante que uma variedade grande de desenhos é observado nos tamanhos maiores de tipos, tamanhos ausentes neste livro. Ou seja, os tipos utilizados neste livro se repetirão em outros, impressos depois, mas nos outros encontramos uma variedade que não há neste. Por estes motivos, avaliamos que sua falta entre os livros analisados não compromete o nosso estudo.

Como disse, também ficou de fora das análises o Carta que el señor doctor jose de antequera y castro [...]. Esta obra é, como se vê pelo nome, uma carta. A folha de rosto não é bem uma folha de rosto, é apenas a folha de início da carta com o título em letras não maiores que $18 \mathrm{pt}$, uma capitular e então o início do texto, que ocupa seis páginas ao todo. Rapidamente percebe-se que os tipos utilizados nesta página inicial, a única que pude examinar, são os mesmos utilizados em outros livros guaraníticos. Por se tratar de uma obra curta, sem folha de rosto propriamente dita e portanto, com poucas possibilidades de conter uma variedade grande de tipos, excluí esta obra das análises sem muitos pesares.

Antes de seguir para as análises, faço duas últimas observações: A cada livro apresentado, incluí brevemente dados relativos a sua descrição física - tamanho, formato e número de páginas. Consultei estes dados na ficha catalográfica dos livros, na John Carter Brown Library, elaborada segundo os padrões da American Library Association ${ }^{39}$. Segundo estes padrões, inclui-se na descrição física dos livros a altura do livro (e não a largura) e, para livros publicados antes de 180o, inclui-se o formato (abreviados como fol., 4to, 8vo, 12mo, etc.) A medida é tirada com a encadernação - que frequentemente não coincide com o tamanho das folhas - e apresentada em centímetros, sendo que as frações de centímetros contam como um centímetro inteiro - ou seja, uma altura de $12,1 \mathrm{~cm}$ é apresentada na ficha catalográfica como $13 \mathrm{~cm}$. Como as medidas não são exatas, todos os tamanhos que apresento são aproximados. Veremos ao longo do capítulo que isso não prejudica as análises, pois estive mais atenta à diferença de tamanho entre as letras do que à exatidão de suas medidas. 39 Ver informaçōes em <http://rbms.info> - Seção de Livros e Manuscritos Raros da Associação de Bibliotecas Universitárias e
de Pesquisa, uma repartição da Associação de Bibliotecas Americanas.
A segunda observação diz respeito ao tamanho das reproduções fotográficas dos livros. Veremos, no decorrer das análises letras menores, em que estão compostos os miolos dos livros e letras maiores, que são usadas principalmente na folha de rosto, nas capitulares e em aberturas de seções. Para melhor apreciação do desenho das letras, as letras menores aparecem nesta dissertação sempre 4,7 vezes maior que seu tamanho real e as letras maiores aparecem 2,7 vezes maior que seu tamanho real, a não ser que esteja indicado o contrário.

\subsubsection{Letras impressas em Loreto}

INSTRUCCION PRACTICA PARA Ordenar Santamente la vida; que ofrece El P. Antonio Garriga de la Compañia de Iesus. Como brebe memorial, y recuerdo à los que hazen los exercicios espirituales de S. Ignacio de loyola Fundador de la misma Compañia. En Loreto, con licencia de los Superiores en la Imprenta de la Compañia Año de 1713

O Instruccion practica para ordenar santamente la vida [...] é um livro de $14 \mathrm{~cm}$ em oitavo $^{40}$, com 120 páginas. Não há itálicos neste livro, nem capitulares. O que se vê na folha de rosto [FIGURA 42 PP 62-63] se repetirá por todo o miolo: um tipo romano, em dois tamanhos diferentes que equivalem, aproximadamente, ao que hoje chamaríamos de corpos $14 \mathrm{pt} \mathrm{e} 18 \mathrm{pt}$

A quantidade de tinta que cada página recebeu na impressão é em geral alta, mas não é homogênea, varia de página para página: a maioria é escura, outras são claras [FIGURA 43 $\cdot$ PP 64-65]. E varia também numa mesma página, o que sugere que as faces dos tipos não estavam niveladas no momento da impressão, ou que o papel não foi pressionado por igual sobre as faces.

O excesso de tinta e irregularidade da impressão dificulta apreciar o desenho das letras nesta impressão. Há que se demorar observando as formas e não fiar-se em detalhes, ou melhor, não fiar-se em características mais suscetíveis a mudanças, como o desenho das serifas, especialmente nos tipos menores e ainda mais nas minúsculas. Muitas conjecturas são possíveis, mas poucas vezes tive certeza o suficiente para dizer que uma minúscula tem este ou aquele desenho de serifa, tamanha são as variações que encontrei, veja-se, por exemplo, as serifas do i minúsculo [FIGURA $44 \cdot \mathrm{P} 66]$

40 Um livro é "em oitavo", ou in-octavo (abrevia-se 8vo), quando é formado a partir de cadernos de 8 folhas ou 16 páginas, que resultam da seguinte operação: imprime-se numa folha grande oito páginas de cada lado da folha. Esta folha é então dobrada três vezes para formar o caderno, varios cadernos são reunidos para formar o livro. As bordas são então refiladas. Se na mesm folha grande fossem impressas quatro paginas de cada lado e esta fosse então dobrada duas vezes, o resultado serriam cadernos de quatro folhas ou oito páginas, assim é o livro "em quarto", ou in-quarto (abrevia-se 4 vo). O tamanho da página que resulta desta operaçāo depende do tamanho da folha inteira usada para impressão e do quanto foi refilado. Segundo Tschichold (2007 


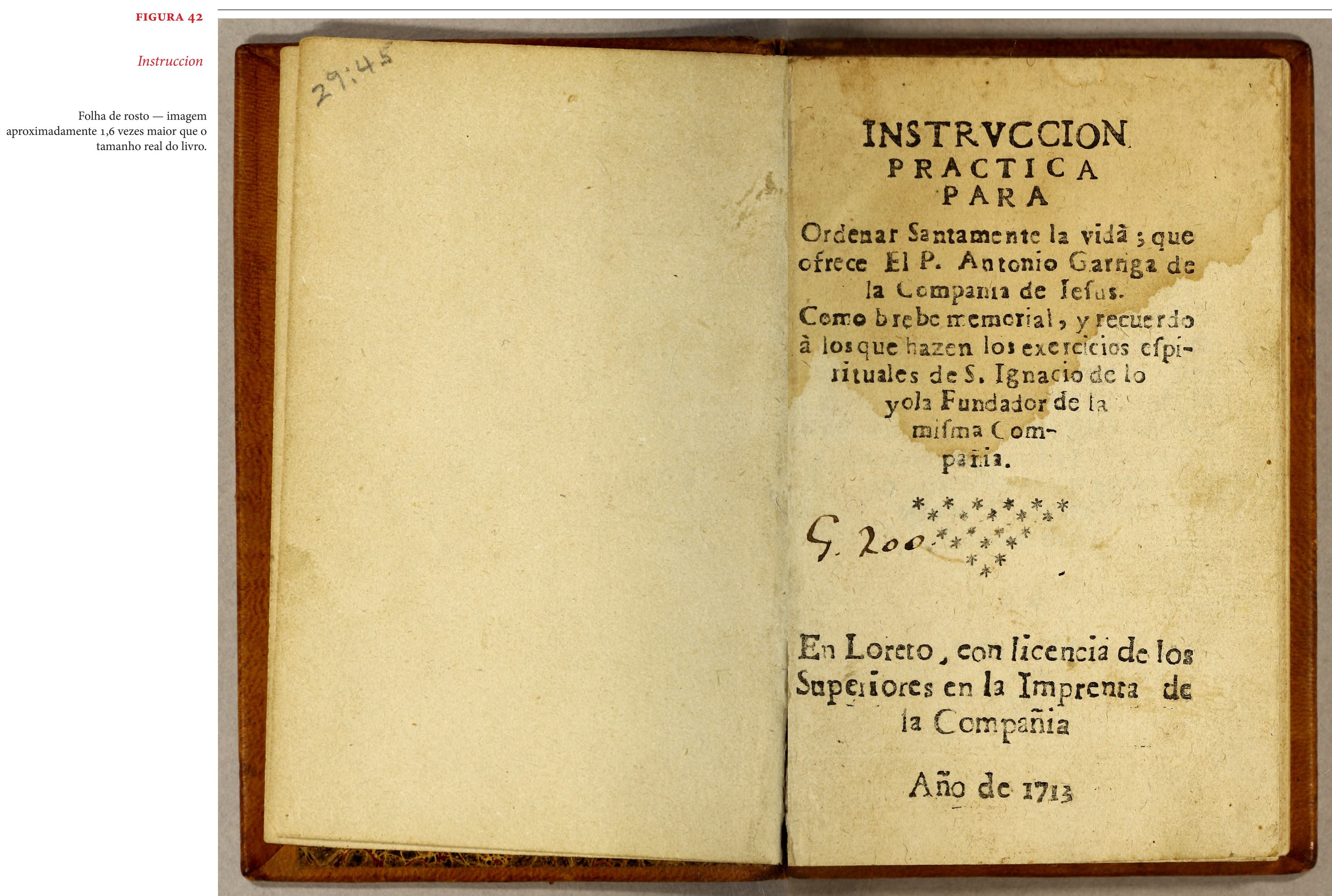




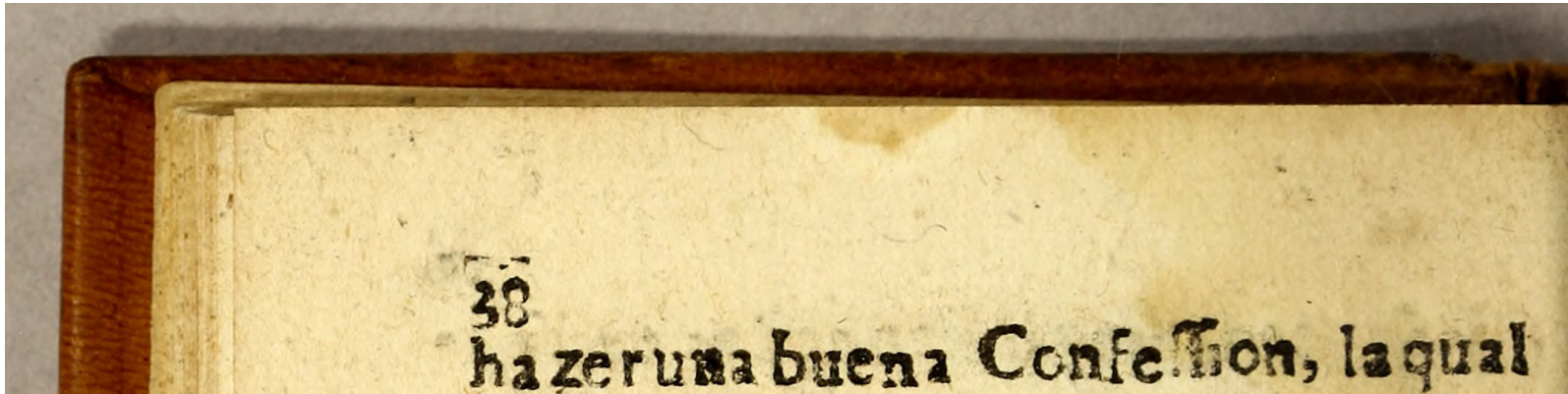
fuer con veriente, que frenqueniafies à lo renos una vezcadames: $\$ .14$.

DELAS CALIDADES

DE LA CONFESSION.

Ias calidades, que ha de tener la buena confeffich, fon eftas; el fer volua zaria, premsditada, diligente, enicra, acculatoria, pro pria, convita, vergonzofa, humilde, contada, verdadera, $y$ defraud a

Efcure unas conffefiones, que hai de tablilla. Dexa e $f_{2}$ seneralida. des, defcicade io particulars y confiefla lo cierro, como cierto; y lo dujóo, como dudofo.

Para averiguar el numero de las culpas confidera el viempo, la inclinacion, elerado, la compañia , y las céfecies de los fecados, difcurriendo por los randamien. tos dela ley de Dios, y de 13 i. glefia, por los fiete pe ados mortales, por los Sacramento: y por los fenidos y a verigua, f faltafe de penfamienso de parabra, ò de obra. Si poromifion, ó por par. ricpacion + con derando aquellas comunes circunfacias, que calfcan rucho las acciones humanas - 1. Quven ?2. Que cora.z.En donde? 4 . Con quien, i conque redios? 9. Quanias veze:?6. Porque? 7. De que mancra? 8. Qunado?

Los actos que han deconcurrirde tu partecono infrumento de la gracia que has d: recebirifon; la Contricion, Confelion, y Satisfaccion. Antes deronfeffar is picados procura tener el mayor

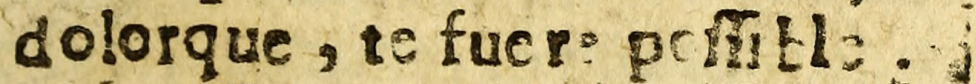
Clama, y dile à Dios. 
As proporções internas dos caracteres, ou seja, o modo como as partes de um mesmo caractere se relacionam, são características que dependem menos da qualidade da impressão para serem percebidas, portanto, me ative mais a elas na observação dos tipos usados na impressão deste livro.

À primeira vista, não percebi diferenças entre as minúsculas do mesmo tamanho, todas parecem vir de uma mesma fonte, salvo uma pequena diferença entre a altura-x do $\mathbf{n}$ minúsculo com e sem til, no corpo 18pt [FIGURA 45]. n e ñ são tratados como caracteres separados, ou seja, o ñ é um tipo completo, e não uma junção do tipo $\mathbf{n}$ com um separado til. Isto explica a diferença no desenho. Entretanto, não é uma regra que esta diferença ocorra. No Arte de lengua mexicana [...] (1717), impresso no México, vemos n e ñ com o mesmo desenho, para dar um exemplo ${ }^{4}$ [FIGURA 46].

No Instruccion practica [...] n é a única letra que aparece com e sem acento entre os tipos deste tamanho (18pt). Assim, não é possível verificar se a diferença na altura de caracteres com e sem acento é uma característica dessa fonte, ou algo que ocorre apenas entre $\mathbf{n}$ e $\tilde{\mathbf{n}}$

Em $\mathbf{n}$ e $\tilde{\mathbf{n}}$ do tamanho menor (14pt) não há esta diferença de altura e, ainda que seja possível desconfiar de alguma diferença entre as formas de a e à - pois algun desenhos de à parecem mais largos [FIGURA 47] - não é algo que se possa afirmar com tanta certeza.

A mesma diferença parece se repetir em um a do corpo 18pt [FIGURA 48]. Como se vê pelas figuras, é difícil apontar se estas diferenças estão no desenho ou se são apenas diferenças decorrentes da impressã $0^{42}$. Por enquanto, o que se pode afirmar com certeza é apenas a diferença entre $\mathbf{n}$ e $\tilde{\mathbf{n}}$ de corpo 18pt. Uma diferença que se dá no desenho de tipos de um mesmo tamanho.

As maiúsculas, por serem maiores, permitem mais segurança nas comparações. Logo na folha de rosto percebi que o $\mathbf{R}$ maiúsculo de corpo 14 pt é diferente do $\mathbf{R}$ maiúsculo do corpo 18pt. Agora estou falando de uma diferença no desenho de tipos de tamanhos diferentes. Neste livro há R's maiúsculos de dois tipos: um com a perna reta e mais longa, que aparece apenas no corpo $18 \mathrm{pt}$ e outro com a perna curva e mais curta, que aparece apenas no corpo 14pt [FIGURA 49].

Já que esta diferença no desenho dos R's é inegável, me pareceu sensato verificar se o mesmo ocorre comparando-se outras maiúsculas. A mesma diferença ocorre

41 Verificamos também em livros impressos em outras datas ou lugares: Arte y vocabulario en la lengua general del Peru [...] Lima 1728

Sempre que possivel, utilizei nas figuras os caracteres mais bem impressos, com contornos bem definidos, para melhor apreciação do desenho das letras. Entretanto, nem sempre foi possivel. Expresser todas as minhas duvidas no texto e tratei de incluir diversas ocorrenncias do mesmo caractere, impressos com mais e menos tintas, para que o leitor e a leitora possan ilustram a michadescrass entre $\mathbf{P}$ 's de 18 pt e 14pt. Mesmo que este caractere não tenha uma "perna", como o $\mathbf{R}$, que deixa a diferença bastante nítida, percebe-se que o desenho dos bojos não coincide [FIGURA 50].
FIGURA 44

Instruccio

\section{1}

i minúsculo (18pt e 14pt) na folha de rosto.

FIGURAS

45 e 46

Instruccio

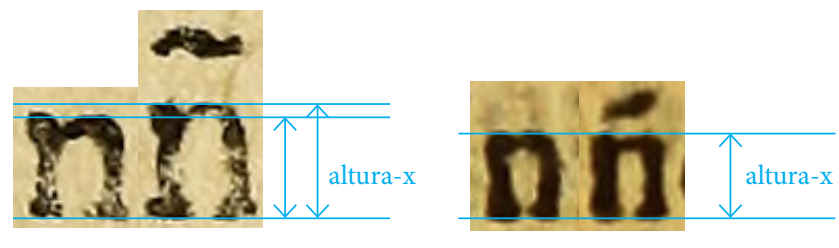

$\mathbf{n}$ e $\tilde{\mathbf{n}}(18 \mathrm{pt})$ no Instruccion, e no Arte de la lengua mexicana.

FIGURA 47

Instruccic

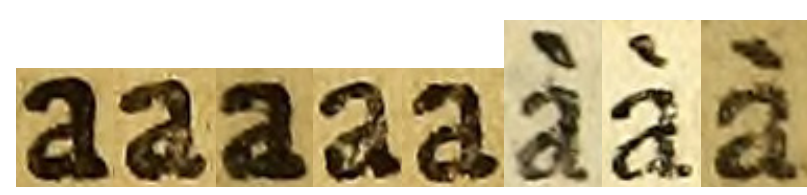

a e à (14pt) no Instruccion. Os dois últimos à's parecem ter o desenho mais largo.

FIGURA 48

Instruccio

\section{$23232 a$}

a (18pt) no Instruccion. O último a parecem ter o desenho mais largo.

FIGURA 49 Instruccio

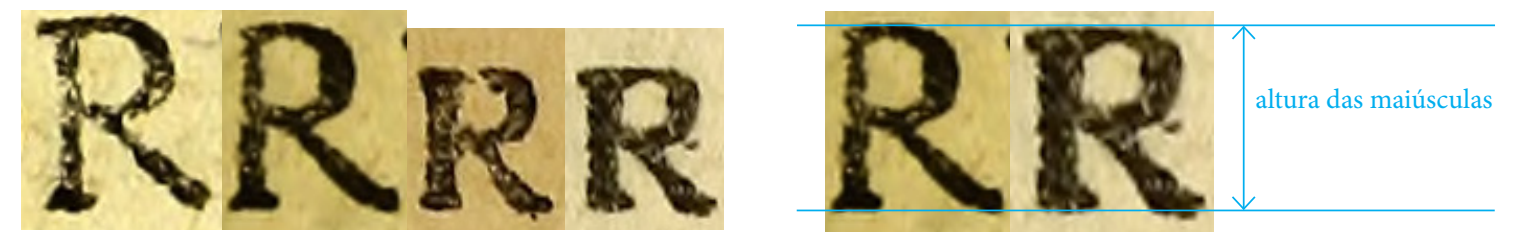

R nos corpos 18pt e 14pt. Ao lado estão igualados segundo a altura das maiúsculas, para comparação.

FIGURA 50 Instruccion
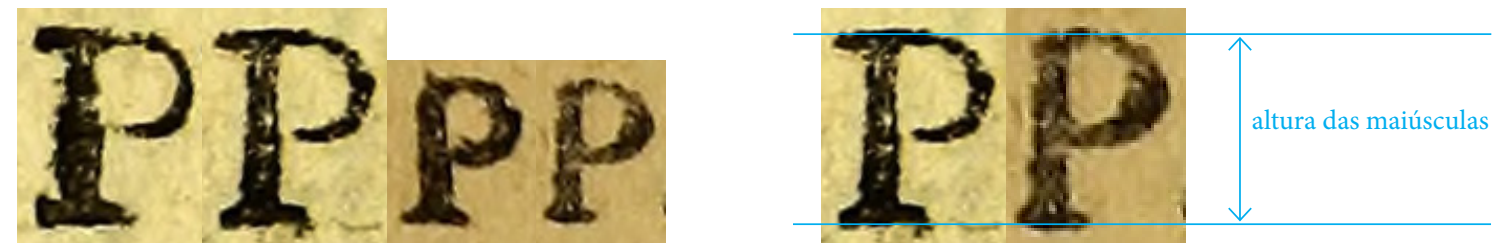

P nos corpos 18pt e 14pt. Ao lado estão igualados segundo a altura das maiúsculas, para comparação. 
Não seria possível afirmar o mesmo, com tanta certeza, se a comparação fosse feita a partir de caracteres com características menos marcantes. Por exemplo, o $\mathbf{O}$ maiúsculo do tamanho $18 \mathrm{pt}$ parece mais oval que o $\mathbf{O}$ maiúsculo do tamanho $14 \mathrm{pt}$, mas a diferença é muito sutil [FIGURA 51].

A mesma diferença entre tamanhos persiste nas proporções das minúsculas: os caracteres do tamanho menor (14pt) têm descendentes e ascendentes mais curtas que os caracteres do tamanho maior (18pt) [FIGURA 52]. Novamente, a diferença no desenho dos tipos de 18pt e 14pt seria imperceptível se tomássemos como referência outros caracteres minúsculos. Por exemplo, apesar das inúmeras variações nas formas das serifas, decorrentes da impressão, que vimos antes, podemos observar que algumas vezes o desenho do i minúsculo em 18pt e 14pt coincide muito [FIGURA 53].

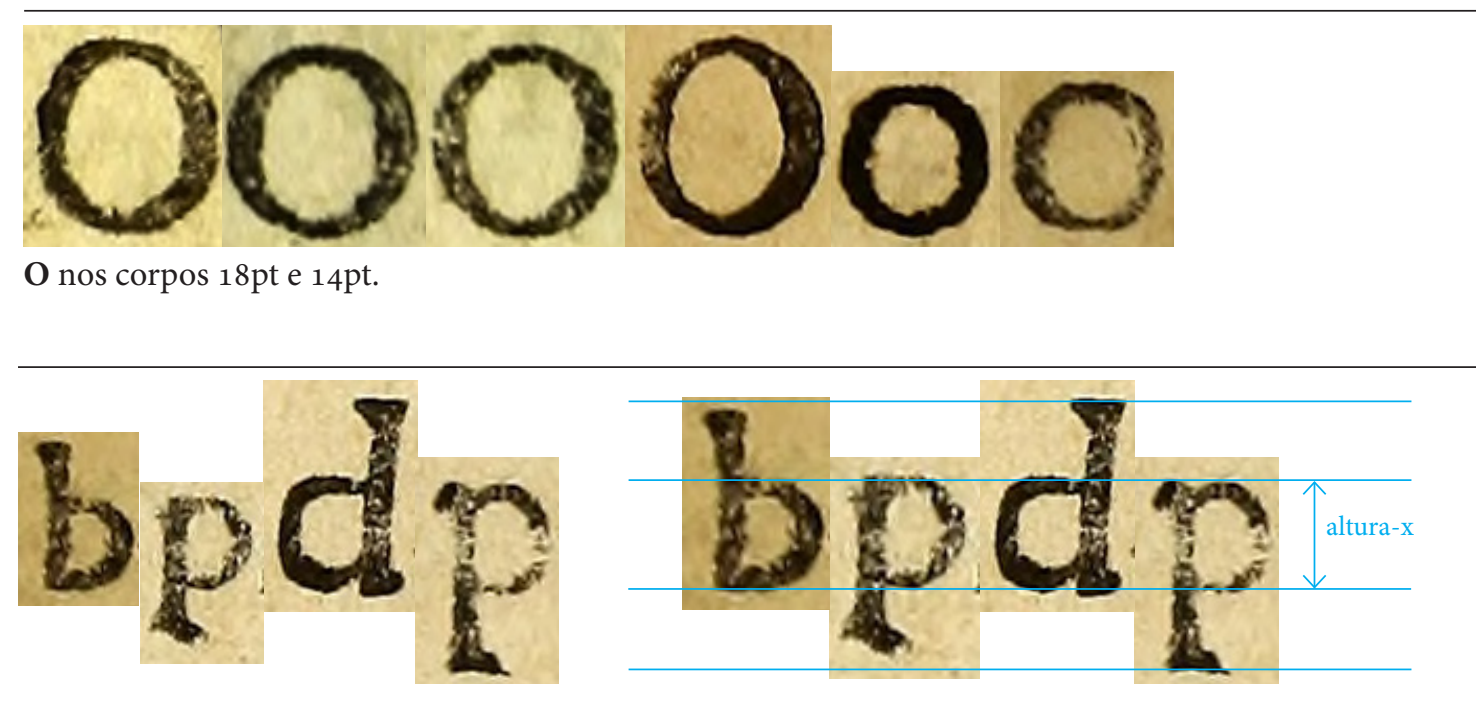

FIGURA 51 Instruccion

Caracteres com ascendentes e descendentes nos corpos 18pt e 14pt. Ao lado igualadas segundo a mesma altura-x para comparação.

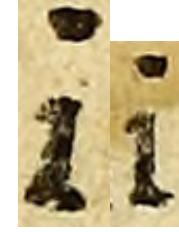

i nos tamanhos 18pt e 14pt.

A partir destas primeiras observações, já podemos afirmar que em Loreto estão em uso, pelo menos, dois corpos - 14pt e 18pt - de duas fontes diferentes, e não dois corpos da mesma fonte.

$$
\sim
$$

Este é um bom exemplo de como foi todo o percurso de análise das letras impressa guaraníticas: isolei os diferentes tamanhos de caracteres, reuni os mesmos numa linha de base comum e comparei as formas, as serifas - quando possível - e as proporções dos caracteres, sempre tentando estabelecer diferenças e semelhanças entre caracteres de um mesmo tamanho, e entre tamanhos diferentes. Foi essencial manter-me sensível ao fato de que, na imprensa guaranítica ou em qualquer outra impressora do mundo, há variações de desenho que são decorrentes do próprio processo de impressão, da tinta e papel utilizados e também da conservação dos tipos.

As comparações ficam mais interessantes a medida que novos livros são incorporados às análises.

MANUALE AD USUM PATRUM SOCIETATIS JESU QUI IN REDUCTIONIBUS PARAQUARIAE VERSANTUR. Laureti Typis P. P. Societatis Jesu. 1721.

Oito anos depois da impressão do Instruccion de Garrida, é impresso em Loreto o Manuale ad usum patrum [...]. Mais volumoso (266 páginas) e em outro formato (in-quarto, $17 \mathrm{~cm}$ ) ${ }^{43}$, o "Manual de Loreto" traz, logo na folha de rosto [FIGURA 54 . · PP 70-71] , uma novidade em relação a seu antecessor, as itálicas. São belas itálicas contendo glifos caudais que estão presentes em grande quantidade em todo o miolo, com direito a várias ligaduras, uma bela eitza itálica $(\&)^{44} \mathrm{e}$ uma cruz de malta.

As itálicas revezam-se com as romanas numa impressão clara, homogênea [FIGURA 55 PP 72-73], que nos permitiu apreciar em mais detalhe as formas das letras. Além da qualidade da impressão, esteve a nosso favor o fato de que o miolo é composto num tipo relativamente grande, mais ou menos equivalente a $18 \mathrm{pt}$. Ou seja, o que no Instruccion era o maior tamanho usado na composição, no Manuale é o tamanho em que está composto quase todo o livro, com poucas exceções: caracteres num tamanho menor, aproximadamente $14 \mathrm{pt}$, aparecem na folha de rosto e em algumas aberturas de seções no miolo, e um tipo ainda menor aparece em algumas páginas do miolo, apenas para marcação tipográfica dos cadernos.

A folha de rosto está composta em tipos de três tamanhos: um maior, romano, sem minúsculas correspondentes; e os dois tamanhos menores com correspondentes minúsculas e itálicas. O tamanho médio, de $18 \mathrm{pt}$ aproximadamente, é aquele com que está composto o miolo, conforme já apontei.

No miolo há vários parágrafos iniciados com capitulares, que têm mais ou menos o tamanho dos tipos grandes ${ }^{45}$ da folha de rosto. Entretanto, logo percebi uma variação de tamanho entre elas: algumas parecem ter o mesmo tamanho das letras

43 Ver nota de rodapé 40 (p.61).

44 A eitza também é chamada de $E$ comercial ou ampersand. Sua forma itálica - $b$ - pode diferir bastante da regular - \& -

45 Ao longo de todo a análise das letras impressas, falarei em "tipos grandes" ou "letras grandes", me referindo às letras vistas na folha de rosto, capitulares e aberturas de seçoes, sempre maiores que as "letras pequenas" ou "tipos pequenos", que são os de 18pt e $14 \mathrm{pt}$ encontrados. 


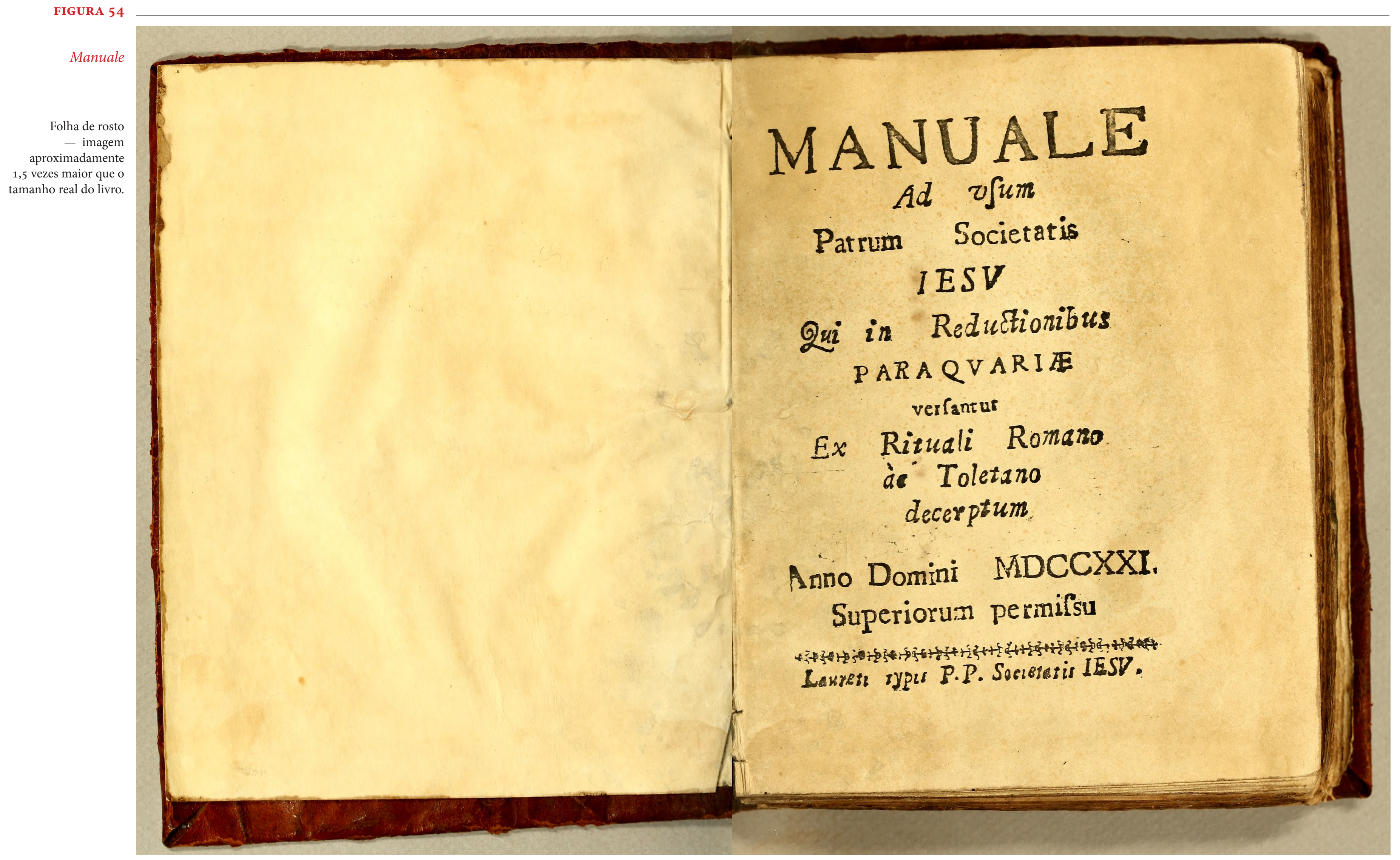




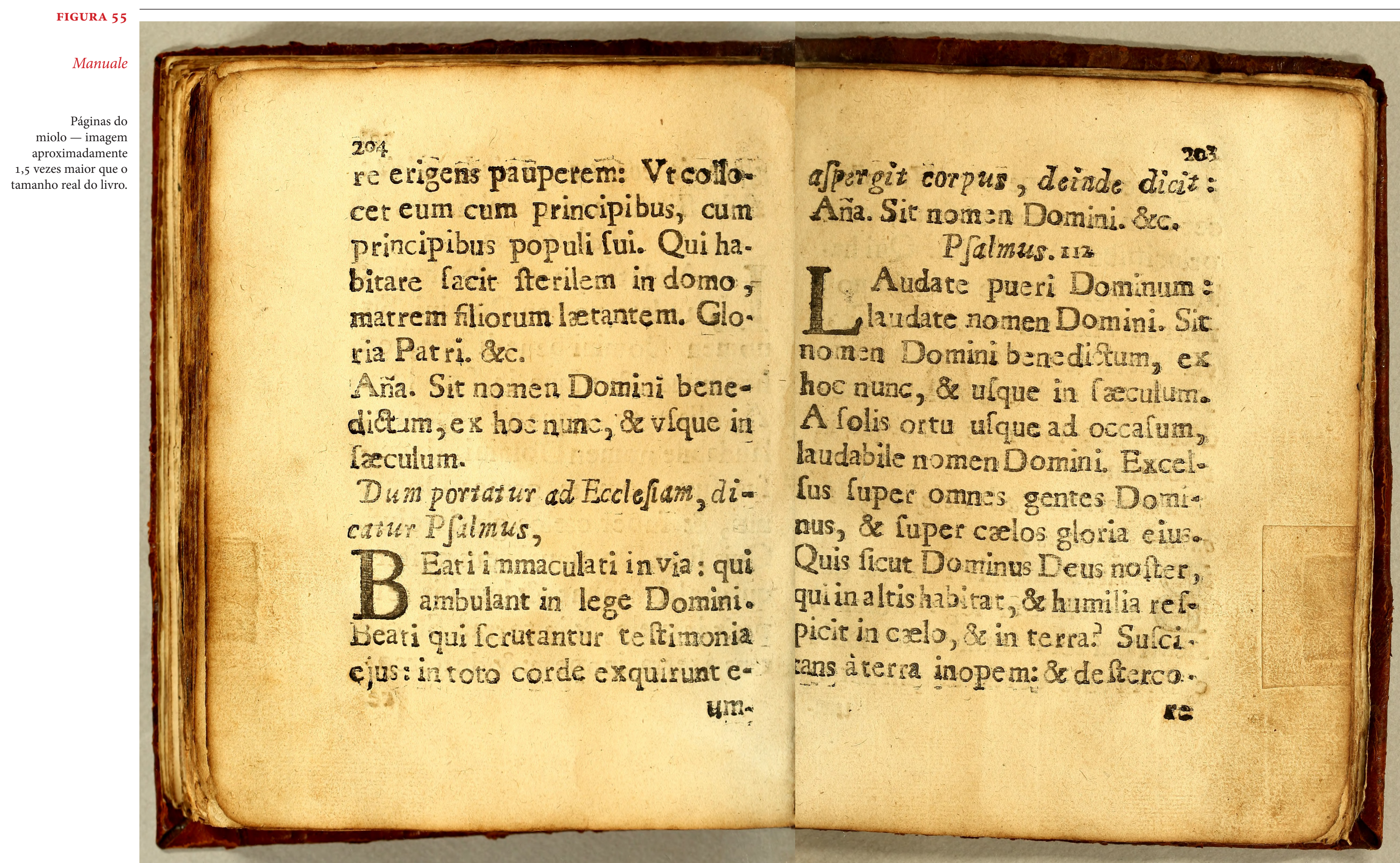


grandes da folha de rosto, mas há tamanhos maiores ainda. Veremos que, apesar da homogeneidade da impressão, o Manual de Loreto é um sortido de tamanhos e de desenhos de tipos.

D, a capitular mais recorrente no livro, confirma esta grande variedade. Há três tamanhos diferentes [FIGURA 56]. Um deles é nitidamente mais alto, os dois outros, menores, têm quase a mesma altura mas as proporções variam: o desenho do menor é mais alongado, como um retângulo, o outro é mais largo, com proporções quadradas. Parece que entre os três, o maior e o menor seguem as mesmas proporções, com o bojo - a "barriga do D" - alongado, enquanto o tamanho médio tem o desenho largo.

A sobreposição de imagens me auxiliou bastante neste tipo de observação. Fazendo com que as hastes coincidam em tamanho, fica mais fácil ver a diferença na proporção dos bojos [FIGURA 57].

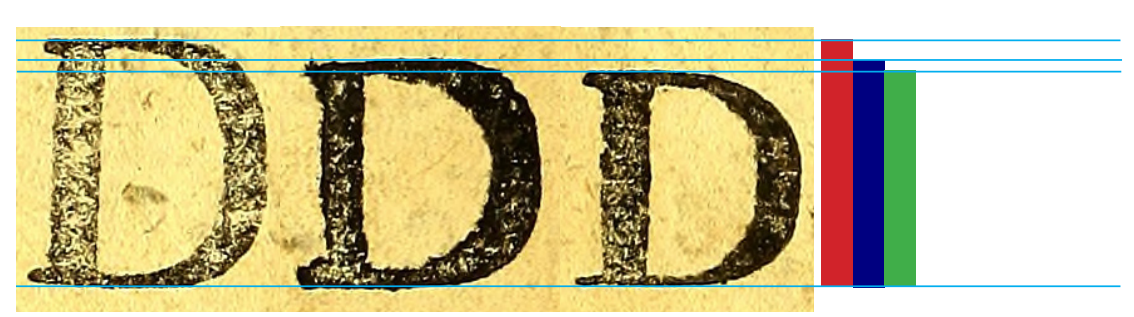

FIGURA 56

Manuale

Três alturas de capitulares $\mathbf{D}$.

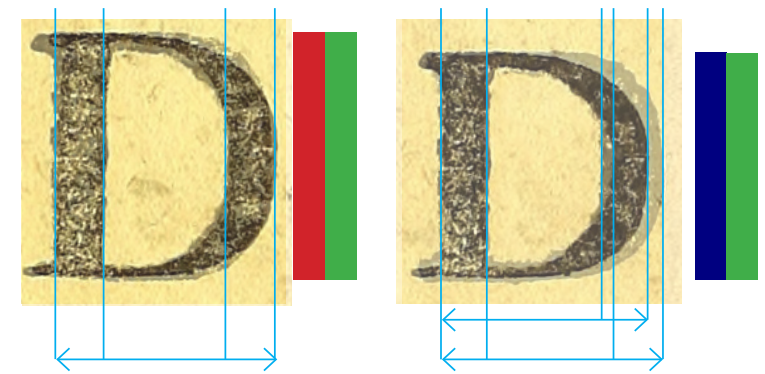

Do lado direito: D maior e $\mathbf{D}$ menor sobrepostos. Do lado esquerdo: D médio e $\mathbf{D}$ menor sobrepostos.

Dentre as vinte e três ocorrências de $\mathbf{D}$ capitular, treze têm o tamanho maior, três o tamanho médio e sete o tamanho menor. Para nossa sorte, a impressão é muito nítida, deixa ver que o desenho de cada um dos três $\mathbf{D}$ 's se repete consistentemente em cada um dos tamanhos. Quer dizer: os de tamanho maior e os de tamanho menor têm sempre o desenho alongado, o de tamanho médio tem sempre o desenho largo. Ou seja, não é o caso de imaginar que, por se tratar de uma letra muito recorrente, ao faltarem $\mathbf{D}$ 's algumas peças foram improvisadas, de madeira, à mão ou de qualquer outro jeito, para terminar a composição do livro. Pelo contrário: São três tipos diferentes, presentes em quantidade razoável cada um, que vieram de três matrizes diferentes. Com tranqüilidade, podemos afirmar que na tipografia de Loreto havia D's grandes de três fontes diferentes. A isso, acrescento que provavelmente estas fontes estavam misturadas numa mesma caixa, a julgar pelo uso indistinto dos tamanhos.

Se isolar os desenhos das letras para compará-los nos dá a vantagem de perceber a presença de diferentes tipos, para afirmar que os tamanhos disponíveis eram usados sem distinção, há que se retornar ao livro e olhar o tipo em sua página de origem. Não é a toa que a capitular $\mathbf{D}$ seja tão freqüente neste livro. O Manual de Loreto traz uma compilação de textos litúrgicos em guarani e latim, assim, há muitas orações as quais estão indicadas sempre por "oremus" ou "oratio", a que segue um novo parágrafo, com capitular, iniciando frases como: Deus, qui miro ordine Angelorum [...]; ou Deus, qui inter Apostolicos Sacerdotes [...]; ou Deus omnipotens, Pater Domini nostri. As orações que não começam com "Deus" começam com "Domine Deus". E não é que os maiores dos D's sejam usados para "Deus" e os menores para "Domini". Ao que tudo indica, o compositor destas páginas lançava mão de $\mathbf{D}$ 's que estavam misturados, sem escolher os maiores para um fim e os menores para outro.

Insisto nesta afirmação não para sublinhar uma composição descuidada. Estes três tipos têm tamanhos muito parecidos e não é de se esperar que um tipógrafo aprendiz ou atarefado pudesse distingui-los se já estivessem misturados. Mas o fato de serem fontes diferentes é relevante. Se as matrizes eram feitas nas missões, e os tipos fundidos ali, como relatavam os padres jesuítas, porque eles teriam três matrizes diferentes para $\mathbf{D}$ 's tão semelhantes? Esta é uma pergunta que permanecerá conosco por todas as análises. O que acharemos no percurso, traz à luz os recursos de que dispunham os compositores dos livros guaraníticos e a discrepância entre estes recursos e um discurso que enfatiza a áurea de rareza desses livros "com tipos fundidos nas missões e impressos por guaranis".

Outras capitulares do Manuale parecem encaixar-se num dos três tamanhos de $\mathbf{D}$ e em alguns casos parecem ser de um mesmo tipo, pois seguem as mesmas proporções: do tamanho médio, com desenho quadrado e mesma espessura de haste há: D

$\mathbf{P} \cdot \mathbf{E} \cdot \mathbf{F}$. Também as serifas destes tipos são muito semelhantes. Sem hastes, mais com a mesma altura, acrescento a este grupo: C e N [Figura 58].

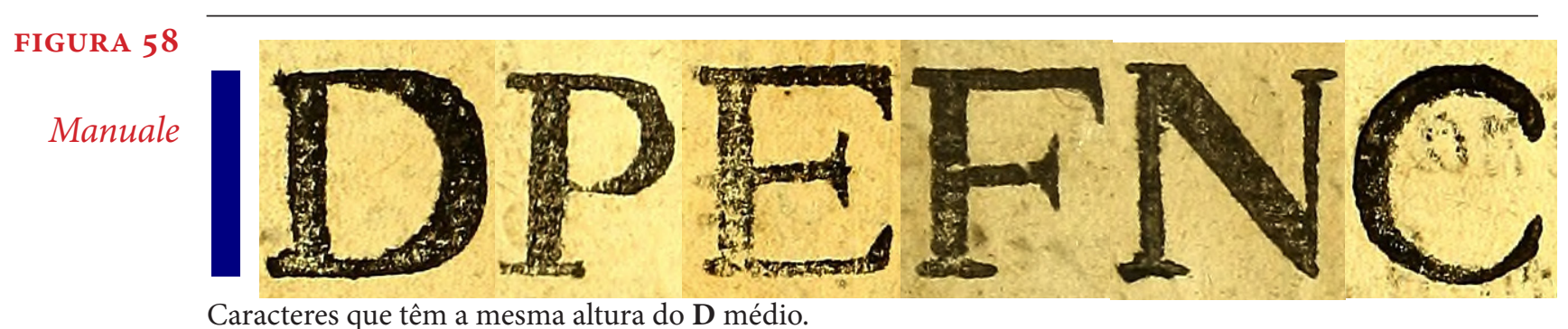


Mas mesmo "encaixando-se num dos três tamanhos", alguns caracteres guardam peculiaridades que só podem ter vindo de outras matrizes. É o caso do E da folha de rosto. Ele têm o mesmo tamanho dos E's grandes do miolo, e também esse desenho quadrado, pouco alongado. Mas vê-se pela barra horizontal média (o "tracinho do E”) que são tipos diferentes, uma barra é mais curta que a outra [FIGURA 59].

Esta simples característica desencadeia a percepção de uma série de outras diferenças: as serifas são mais grossas, a transição das hastes para as serifas são mais suaves e talvez ele nem seja exatamente do mesmo tamanho do outro E. Esta é a única ocorrência desse desenho de $\mathbf{E}$ em todo o Manual de Loreto .

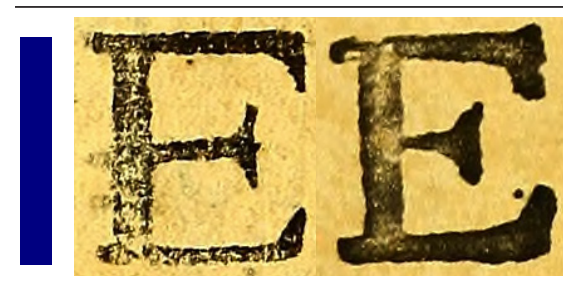

FIGURA 59

E capitular $\mathrm{E} \mathbf{E}$ na folha de rosto. Mesma altura, desenhos diferentes.

Muito provavelmente ele é da mesma fonte do $\mathbf{L}$ também utilizado na folha de rosto As mesmas serifas, o mesmo tamanho, as mesmas proporções [FIGURA 6o]. Esta também é a única ocorrência deste desenho de $\mathbf{L}$ em todo o Manual. Aliás, os caracteres da folha de rosto que têm esse tamanho grande parecem ter sido selecionados especialmente para honrar a abertura do livro. Formam um conjunto muito particular, distinto das letras grandes do miolo. Mas o conjunto tem algumas incoerências internas [FIGURA 61]: Embora E e L sejam muito semelhantes - e talvez seja possível acrescentar $\mathbf{U}$ e $\mathbf{N}$ a este grupo, se tomarmos como critério as serifas ou a espessura dos traços $-\mathbf{M}$ destoa do grupo, por ter a haste horizontal mais fina que a do $\mathbf{N}$ e as duas ocorrências de $\mathbf{A}$ destoam muito. Um $\mathbf{A}$ é mais largo e quadrado, o outro A é mais alongado. A altura da haste varia e o desenhos dos vértices também, um é pontudo o outro quebrado. [FIGURA 62]

No miolo, há três A's grandes, entre as capitulares, e a diferença entre eles se repete, como na folha de rosto: um é mais largo, tem o mesmo desenho daquele $\mathbf{A}$ largo da folha de rosto; e os outros dois são mais alongados, como o $\mathbf{A}$ alongado da folha de rosto [FIGURA 63]. Nenhum deles repete o "vértice quebrado".

Depois do $\mathbf{D}$, as capitulares mais recorrentes são: $\mathbf{C}$, onze ocorrências, em dois tamanhos bem diferentes mas com proporções e serifas iguais [FIGURA 64]; $\mathbf{P}$, nove ocorrências, todos do mesmo tamanho, mas com desenhos diferentes: um tem o bojo mais curto e de traço mais fino que outro; um terceiro, além de ter o bojo mais curto, tem serifas que se apoiam na hastes de forma menos abrupta e mais adnata (fazendo da serifa uma prolongação suave da haste), ao contrários das demais serifas
FIGURA 60

Manuale

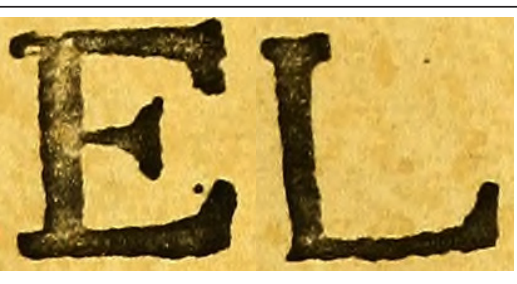

E e $\mathbf{L}$ da folha de rosto.

FIGURA 61

Manuale
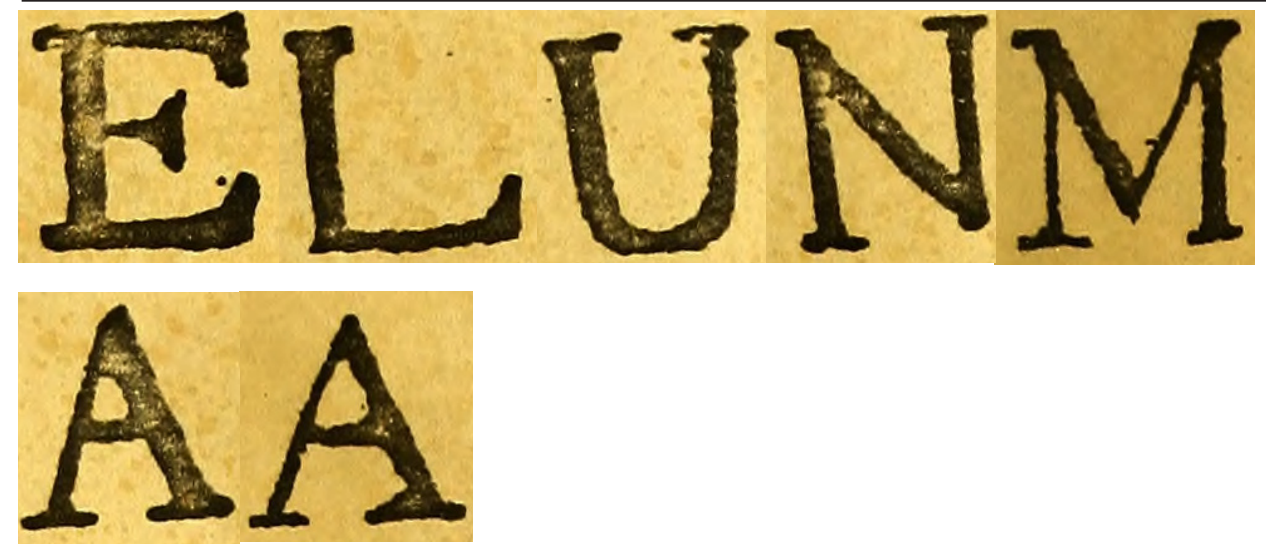

Letras grandes da folha de rosto.

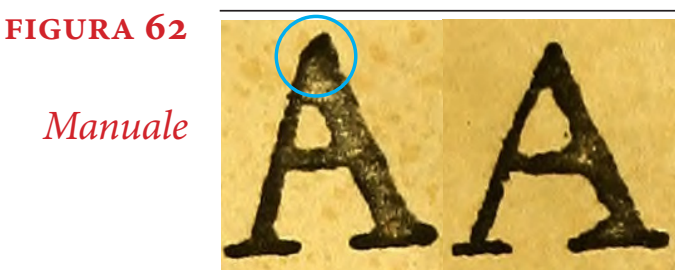

A's na folha de rosto.

FIGURA 63

Manuale

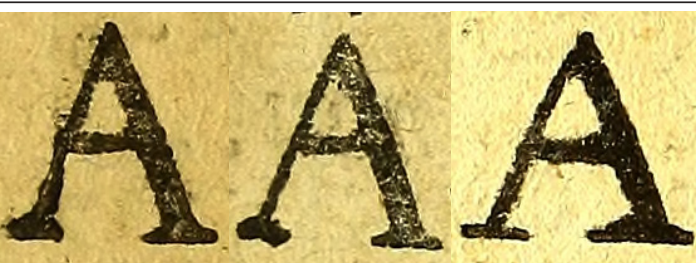

A's no miolo.

FIGURA 64

Manuale

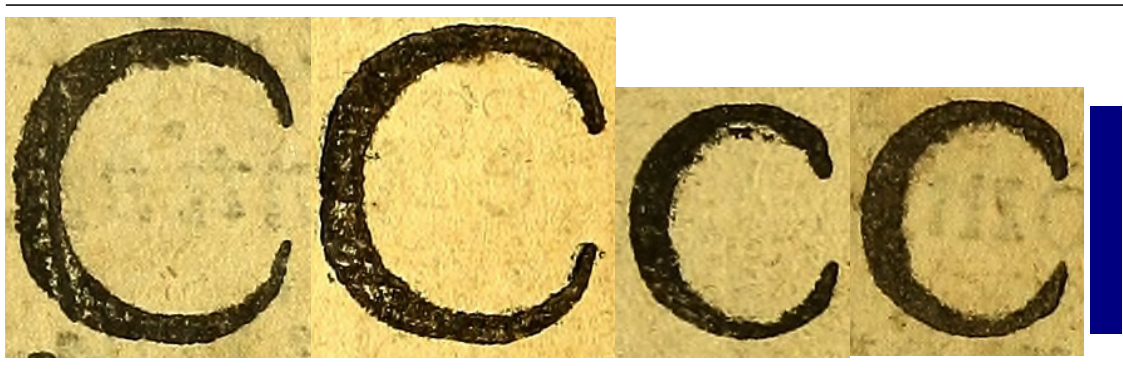

C's em dois tamanhos, com o mesmo desenho 
que surgem abruptamente [Figura 65]. Tudo indica que são fontes diferentes: $\mathbf{P}^{\prime}$ s do mesmo tamanho mas de matrizes diferentes. $\mathrm{O} \mathbf{E}$ aparece seis vezes, todos iguais, o único $\mathbf{E}$ diferente é aquele da folha de rosto, do qual já falamos; Seis ocorrências de I, o tamanho é quase igual, mas vê-se a diferença entre eles no desenho da serifas [FIGURA 66]; Também há seis ocorrências de $\mathrm{O}$, apenas um deles é maior e tem eixo de modulação vertical (os demais tem o eixo inclinado à esquerda) [FIGURA 67]. Além dessas capitulares, há: $\mathbf{A} \cdot \mathbf{B} \cdot \mathbf{N} \cdot \mathbf{S} \cdot \mathbf{R} \cdot \mathbf{F} \cdot \mathbf{L} \cdot \mathbf{T} \cdot$ Æ, que aparecem menos de três vezes cada uma.

Com diferenças mais ou menos sutis, percebe-se a variedade de fontes usadas nas capitulares do Manual. Mas é possível fazer um esforço e agrupá-las por tamanho [FIGURA 68]. Assim: num grupo ficam as maiores $\mathbf{R} \cdot \mathbf{B} \cdot \mathbf{C} \cdot \mathbf{L} \cdot \mathbf{I} \cdot \mathbf{O}$; depois I e $\mathbf{O}$ menores; seguidas de $\mathbf{D}$ e $\mathbf{T}$; em outro grupo $\mathbf{D} \cdot \mathbf{P} \cdot \mathbf{E} \cdot \mathbf{F} \cdot \mathbf{N} \cdot \mathbf{C}$ - mencionados antes (p.59) -; em outro D e A; e, por último, A e S. Sobra um $\mathbf{S}$, solitário, o único com este desenho.

Para além do tamanho, estes grupos parecem manter alguma coerência interna no que tange o tratamento das serifas e proporções internas dos caracteres: Por exemplo, no primeiro grupo $(\mathbf{R} \cdot \mathbf{B} \cdot \mathbf{C} \cdot \mathbf{L} \cdot \mathbf{I} \cdot \mathbf{O})$ os caracteres seguem proporções alongadas, enquanto no quarto grupo $(\mathbf{D} \cdot \mathbf{P} \cdot \mathbf{E} \cdot \mathbf{F} \cdot \mathbf{N} \cdot \mathbf{C})$ seguem proporções quadradas. Mas nem sempre se vê esta coerência: $\mathbf{D}$ e $\mathbf{T}$, no terceiro grupo, têm o mesmo tamanho, mas têm hastes de espessuras diferentes. Enquanto o $\mathbf{D}$ é robusto, com a haste grossa, o T se equilibra singelamente sobre uma haste fina.

Além das capitulares, o que se vê no miolo do Manual de Loreto são tipos romanos e itálicos de aproximadamente 18pt (ver páginas do miolo na figura 55). Além

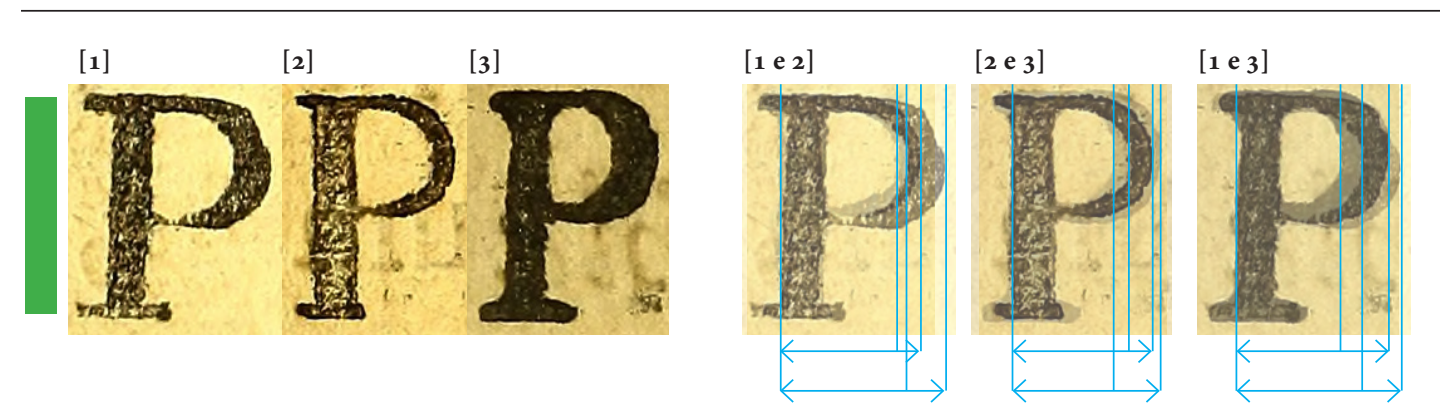

P's, todos do mesmo tamanho. Três desenhos diferentes.
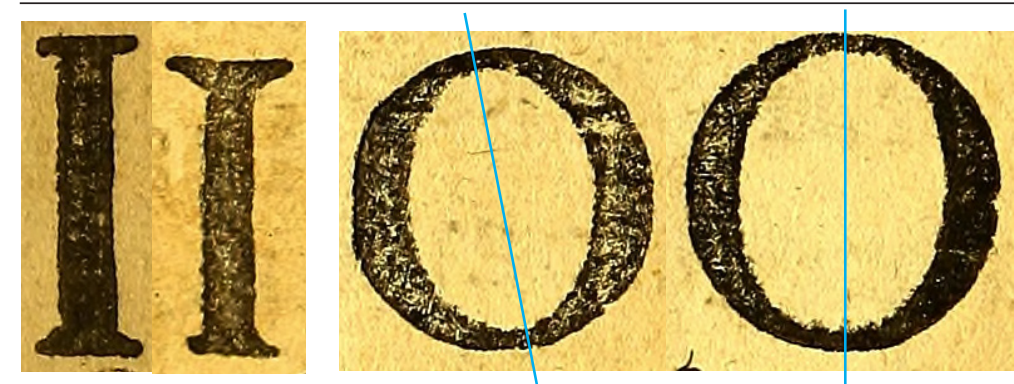

I's e O's em dois tamanhos parecidos.
FIGURA 68 - Manuale. Capitulares agrupadas por altura.
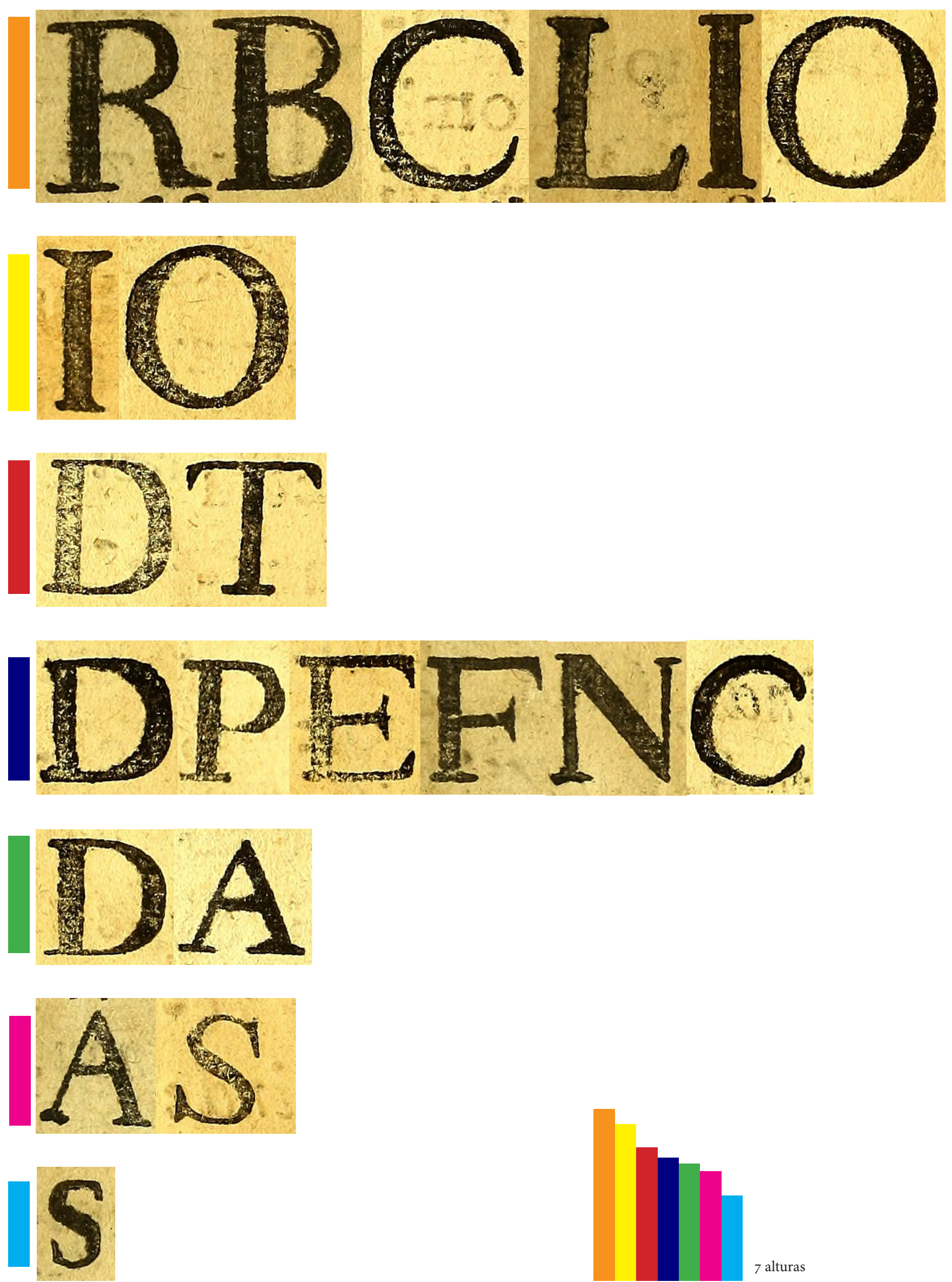
desses, há, nas aberturas de seções, títulos num tipo menor, de aproximadamente 14pt. Os dois tamanhos estão também na folha de rosto e são os mesmos que vimos no Instruccion. Entretanto, há um cruzamento no desenho e tamanho dos tipos: os tipos de corpo $18 \mathrm{pt}$ do Instruccion practica para ordenar santamente la vida [...] correspondem aos tipos de corpo 14pt do Manuale ad usum patrum [...], enquanto os tipos de corpo 14pt do Instruccion correspondem aos tipos de 18pt do Manuale.

É o que se vê comparando as maiúsculas nestes dois tamanhos nos dois livros [Figura 69]. Por exemplo, o $\mathbf{N}$ de $14 \mathrm{pt}$ do Manuale tem proporções alongadas, que se assemelham ao $\mathbf{N}$ de $18 \mathrm{pt}$ do Instruccion. Guardadas as diferenças no tamanho dos caracteres, o desenho é o mesmo. Enquanto que o $\mathbf{N}$ de $18 p t$ do Manuale é mais quadrado e semelhante ao $\mathbf{N}$ de $14 \mathrm{pt}$ do Instruccion. Também nos caracteres L, A $\mathbf{R}$ e $\mathbf{E}$ essa correspondência cruzada entre os tamanhos se repete. Um conjunto tem proporções quadradas, o outro é mais alongado. No $\mathbf{R}$ a diferença está também na extensão da perna, nos tipos de proporções quadradas a perna é longa e se estende além do bojo, nos tipos alongados a perna é mais curta e curva e termina quase na linha do bojo. O E quadrado tem a barra horizontal média (o "tracinho do E") longa, enquanto nos tipos alongados esta barra é curta.

Diferente do que apontei sobre as capitulares, que poderiam estar misturadas, nestes corpos menores os tipos estão separados em quatro conjuntos: Uma tipografia em 18pt e 14pt; Outra tipografia em 18pt e 14pt. Ou seja, podemos afirmar que em Loreto havia no mínimo duas fontes, cada uma disponível em dois corpos, para composição dos miolos. Esta afirmação só é possível observando as maiúsculas, poi nas minúsculas, por serem menores, as diferenças não aparecem tanto. Além disso,

\section{NLARE

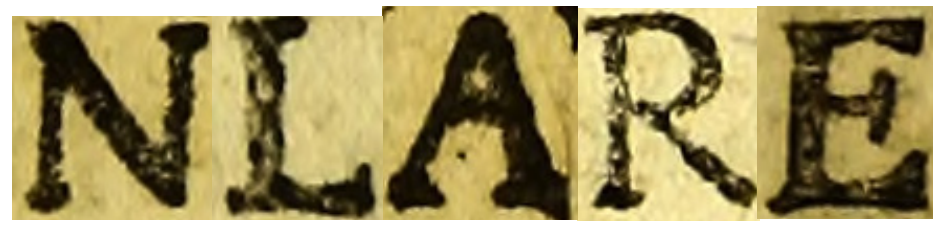

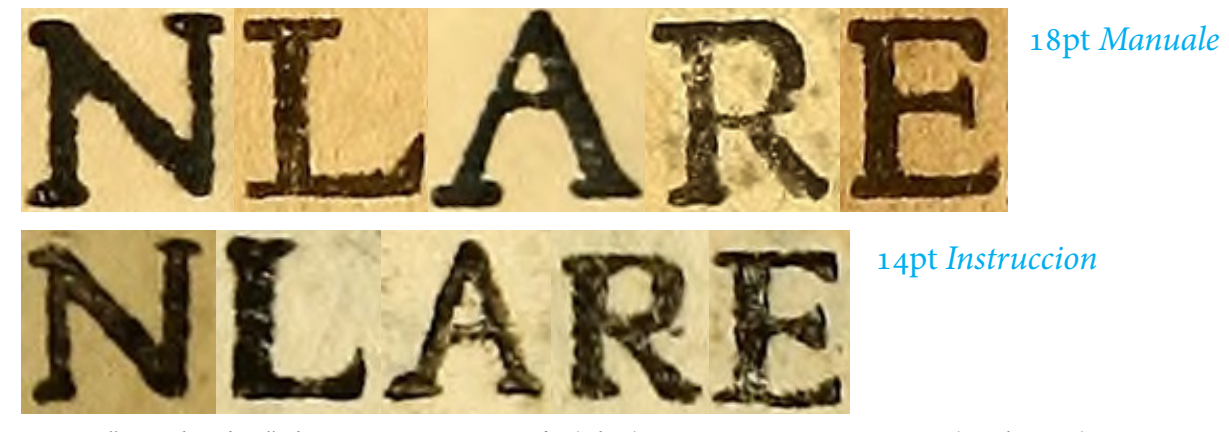

Tipos "quadrados" de 18pt no Manuale (alto) e 14pt no Instruccion (embaixo). são poucas as minúsculas de $14 \mathrm{pt}$ neste livro. Conforme apontei antes, o miolo do Manual de Loreto está composto nos tipos de $18 \mathrm{pt}$, ficando as menores reservadas para aberturas de seções, quase sempre em caracteres maiúsculos. Em todo o Manual de Loreto vemos em 14pt apenas 9 minúsculas (8 caracteres) e 20 minúsculas itálicas (10 caracteres), todas na folha de rosto.

É tentador afirmar que as duas tipografias usadas na composição do miolo correspondem a tipografias usadas nas capitulares, já que também lá havia tipos de proporções mais quadradas e outros mais alongados. Mas não é o que a comparação de caracteres como R, E, que carregam características marcantes (a perna do $\mathbf{R}$ e a barra do E) nos deixa ver. Em cada tamanho estes caracteres seguem proporções próprias, com exceção dos dois conjuntos de 18 pt e 14 pt que identificamos nos miolos. O R grande tem uma perna muito curva, que não se repete em nenhum dos tipos menores, alongados ou quadrados [FIGURA 70]. Os dois tipos de $\mathbf{E}$ grandes também não correspondem aos dois tipos de $\mathbf{E}$ pequenos, as barras horizontais são ora mais curtas ora mais longas, em proporções que não coincidem [FIGURA 71].

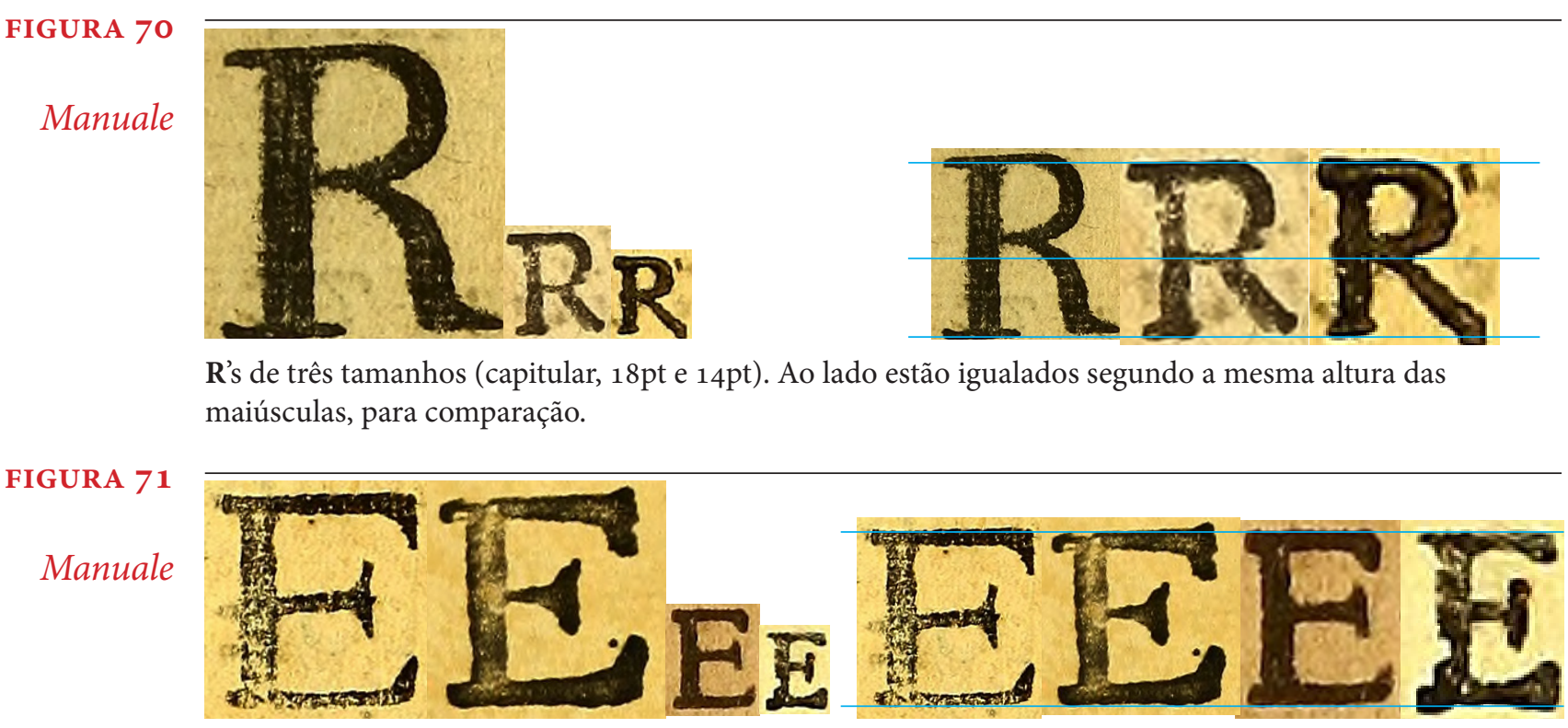

E's de três tamanhos (capitulares, $18 \mathrm{pt} \mathrm{e}$ 14pt). Ao lado estão igualados segundo a mesma altura das maiusculas, para comparação.

Eu disse que em Loreto havia "no mínimo" duas fontes para composição dos miolos porque o $\mathbf{Q}$ nos lembra que é arriscado formar conjuntos tomando como critério características que não garantem que os tipos sejam de uma mesma fonte. Pode ser que pelo fato de alguns caracteres seguirem as mesmas proporções eles façam parte de uma mesma tipografia, pode ser que não. Com sua cauda, o $\mathbf{Q}$ costuma ser bastante útil na identificação de tipos, mas aqui, não há cauda que coincida nos dois conjuntos que pensamos ter encontrado. Os Q's maiúsculos de que dispomos no Instruccion são todos de tamanho 14pt (não há Q's de tamanho 18pt neste livro): 
um tem a cauda curta, outro tem uma cauda longa, que se estende por baixo de seu caractere vizinho, um u minúsculo. Pela lógica anterior, estes Q's de $14 \mathrm{pt} \mathrm{do}$ Instruccion deveriam parecer-se com os Q's de $18 \mathrm{pt}$ do Manuale, mas não é o que acontece [FIGURA 72]. A cauda do $\mathbf{Q}$ do Manuale é curta e parece menos inclinada.

A diferença na inclinação da cauda pode ser decorrente da impressão e a cauda longa pode ser o que se chama kerning - um recurso para ajustar o espaçamento entre determinados pares de caracteres ( $\mathbf{Q}$ e $\mathbf{u}$, por exemplo) permitindo que partes de um tipo se estendam sobre outro - ou pode ser que estes dois caracteres estivessem fundidos num mesmo tipo. De todo modo, a presença desses Q's, aparentemen te diferentes entre si, faz lembrar que, como vimos nas capitulares, pode ser que no tamanhos menores também houvesse tipos misturados, vindos de fontes diferentes.

No Manual de Loreto as itálicas aparecem em abundância no tamanho 14pt. Há algumas itálicas menores apenas na folha de rosto, são 20 minúsculas itálicas (10 caracteres) em 18pt. São poucas estas menores para qualquer comparação entre os tamanhos. Por outro lado, compará-las com as romanas não me pareceu sensato, chegaríamos, no máximo, à conclusão de que formam outro conjunto, o que já sabemos porque são itálicas. Vamos guardá-las para comparações com outras itálicas que aparecerão em outros livros. Por ora, me contento em dizer que são itálicas claras e de contraformas amplas, com vários glifos caudais e ligaduras [FIGURA 73] Há apenas duas diferenças internas ao conjunto."

A primeira, mais sutil e menos surpreendente, diz respeito ao eixo de inclinação [FIGURA 74]. as minúsculas sem ascendentes ou descendentes, como $\boldsymbol{i} \cdot \boldsymbol{m} \cdot \boldsymbol{n}$ $\boldsymbol{u}$, são mais inclinadas do que $\boldsymbol{p} \cdot \boldsymbol{q} \cdot \boldsymbol{l} \cdot \boldsymbol{d} \cdot \boldsymbol{f} \cdot \boldsymbol{b} \cdot \boldsymbol{h}$, minúsculas com ascendentes ou descendentes. $\mathrm{O} j$ é o menos inclinado de todas. O eixo de modulação do traço também varia, ora inclinado para a esquerda, como em $\mathbf{e} \cdot \mathbf{a} \cdot \mathbf{d}$, ora para a direita, como em $\boldsymbol{p}$ e $\boldsymbol{b}$ [FIGURA 75]. Estas variações não surpreendem tanto se lembrarmos que várias itálicas mundo a fora tinham estas características nesta época. Bringhurst as classificaria de letras barrocas,

as letras barrocas em geral diferem das renascentistas das seguintes maneiras: o eixo do traço da caixa-baixa romana e itálica varia bastante dentro de um único alfabeto, a inclinação média da itálica é de $15^{\circ}$ a $20^{\circ}$ e muitas vezes varia consideravelmente dentro do mesmo alfabeto $[\ldots]$

(BRINGHURST, 2005:141)

Mas não nos interessa tanto separar as letras guaraníticas de acordo com sistemas de classificação de tipos, pois, segundo o próprio Bringhurst apontou, "todos
FIGURA 72 Manuale Instruccion

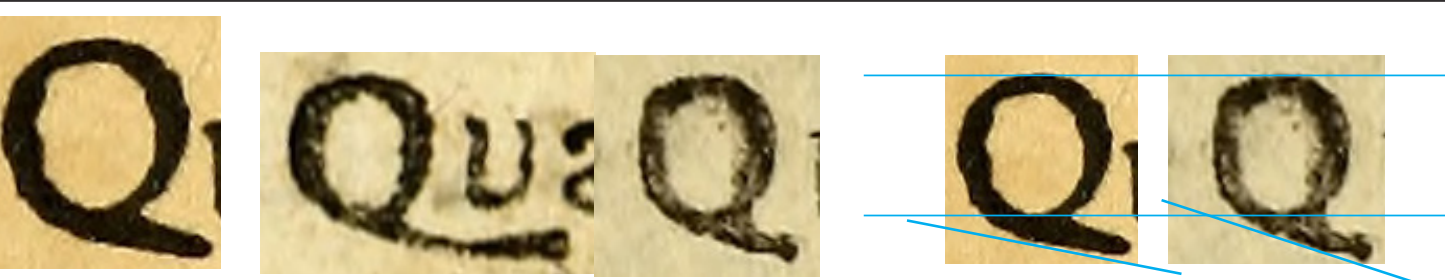

Q de 18pt do Manuale e dois Q's de 14pt do Instruccion (o primeiro com kerning, o segundo sem). Ao lado estão igualados segundo a mesma altura das maiúsculas, para comparação.

FIGURA 73

Manuale

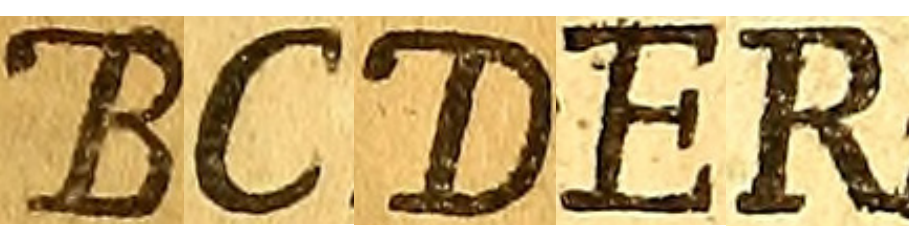

ibbgpotudt fift

Itálicas maiúsculas e minúsculas do Manuale.

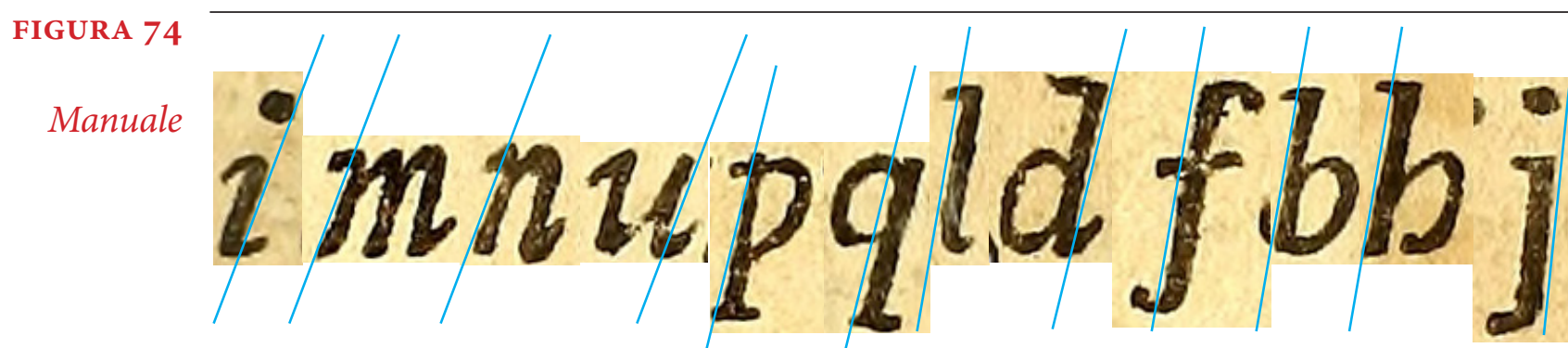

Eixo de inclinação das minúsculas itálicas.

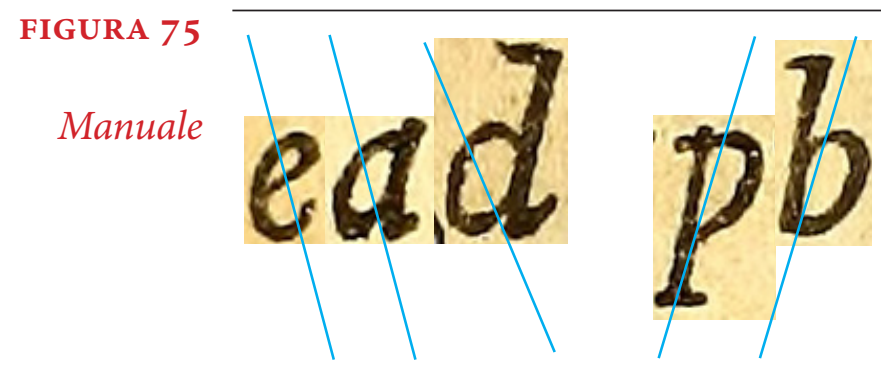

Eixo de modulação das minúsculas itálicas. 
esses sistemas funcionam até certo ponto e deixam muito a desejar" (BRINGHURST 2005:135). Mesmo os termos históricos utilizados pelo autor (Renascentistas, Maneiristas, Barrocas, Rococós) só nos servem se não nos amarrarem em análise de identificação dos tipos e nos permitam olhar as letras e as tensões entre elas no conjunto em que se apresentam.

A segunda diferença interna ao conjunto das itálicas me chamou mais atenção. Há dois tipos de $Q$ itálicos [Figura 76]: um com a cauda mais contida, e outro bastante extrovertido, decorado em espiral, com a cauda longa e curva. Além da

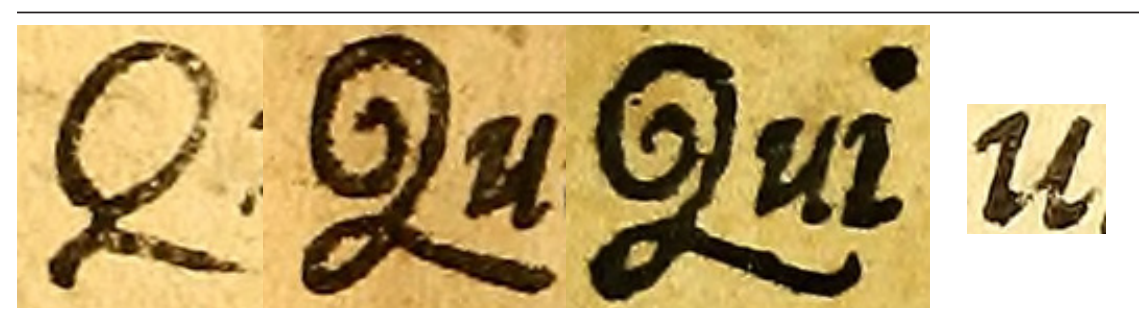

FIGURA 76

Q's itálicos do Manuale e $\boldsymbol{u}$ itálico para comparação.

diferença óbvia entre "extrovertidos" e "não extrovertido", percebe-se uma pequena diferença entre as duas ocorrências de $Q$ 's decorados: em um a cauda se alonga por baixo do vizinho $\boldsymbol{u}$, formando o par " $\boldsymbol{Q u}$ ". No outro, a cauda se alonga a baixo de $\boldsymbol{u}$ e $\boldsymbol{i}$, formando "Qui". Percebe-se que os $\boldsymbol{u}$ 's " $\boldsymbol{Q u}$ " e "Qui" são diferentes de outros $\boldsymbol{u}$ 's itálicos. Por isso, tendo a achar que " $\mathcal{Q u}$ " formam um único glifo, ou seja, estão fundidos num mesmo tipo, e no "Qui" o que vemos há um ajuste de kerning entre "Qu" e $i$.

O Manuale ad usum patrum [... $]^{46}$ foi a última obra impressa em Loreto. Mas já no ano seguinte começaria a funcionar a imprensa de Santa Maria la Mayor.

3.1.2 Letras impressas em Santa Maria la Mayor

VOCABULARIO DE LA LENGUA GUARANI COMPUESTO Por el Padre Antonio Ruiz de la Compañia de IESUS Revisto, y Augmentado Por otro Religioso de la misma Compañia EN EL PUEBLO DE S. MARIA LA MAYOR. El Año de MDCCXXII.

O Vocabulario de la lengua guarani [...] é um livro de $22 \mathrm{~cm}$, impresso em quarto, o primeiro livro impresso em Santa Maria la Mayor [FIGURA $77 \cdot$ PP 87-88]. Este Vocabulario, o mais volumoso de todos os livros que vimos até agora, está composto num tipo pequeno, que nos computadores de hoje em dia mediria 24 pontos.

46 Sobre o Manual de Loreto, Furlong diz que, "En la p. [267] comienza el tratadito De Sacramento Penitentiae que comprende 79pp. s. fs., com una final en bl. Se trata de una publicación diversa, acoplada a aquella, sólo accidentalmente? Aunque hay razones
valederas para la afirmativa, hay una muy poderosa para la negativa: el pliego $H$ comprende las dos postreras páginas del Manuale valederas para la afirmativa, hay una muy poderosa para la negativa: el pliego $\mathrm{H}$ comprende las dos postreras páginas del Manuale "mucho menor", mas o exemplar que consultamos termina mesmo na página 267 e não traz acoplada esta obra-
Veremos este tipo em todos os miolos dos livros impressos em Santa Maria. É um tipo que vimos em Loreto, nas aberturas de seções e folha de rosto do Instruccion practica [...], num tamanho maior, e neste mesmo tamanho nas aberturas de seções do Manuale ad usum patrum [...]

Como outros vocabulários, as páginas estão divididas em duas colunas e não há necessidade de grandes aberturas de capítulos, há apenas tímidas indicações de que inicia-se uma nova letra no vocabulário, feita com um tipo maior, que hoje em dia mediria 30 pontos [FIGURA $78 \cdot$ PP 89-90]. É o mesmo tipo grande, de proporções quadradas e aberturas generosas em que estava composto o miolo do Manual de Loreto. Esta será uma constante nos livros de Santa Maria: as belas letras do Manuale serão usadas nas aberturas de seções e na folha de rosto. Um tipo menor, com as proporções alongadas, será usado na grande massa de texto do miolo. Jamais voltaremos a ver um livro inteiramente composto com as letras do Manuale.

É possível afirmar que no Vocabulario o tamanho 14pt em que está composto o miolo é o mesmo do 14pt do Manual de Loreto graças às características específicas de alguns caracteres, como o R, que, a esta altura das análises, se tornou uma espécie de "caractere-chave" para comparar os tipos menores: a massa grande de texto está composta na fonte que tem o $\mathbf{R}$ com a perna comprida, já as aberturas de seções estão compostas na fonte que tem o $\mathbf{R}$ com perna curta [FIGURA 79]. O E e o $\mathbf{Q}$ maiúsculos confirmam que estes são os mesmos tipos usados em Loreto, e que há, como no Manual, um uso "cruzado" dos tipos: os de 18 pt têm um desenho, os de $14 \mathrm{pt} \mathrm{têm} \mathrm{outro} \mathrm{[FIGURA} \mathrm{80].} \mathrm{Os} \mathrm{maiores} \mathrm{contam} \mathrm{com} \mathrm{um} \mathrm{Q} \mathrm{que} \mathrm{tem} \mathrm{uma} \mathrm{cauda} \mathrm{não}$ muito longa e não muito extrovertida, enquanto o $\mathbf{Q}$ dos menores tem a cauda um pouco mais longa [FIGURA 81]. O E dos maiores tem proporções quadradas, com a barra horizontal média (o "tracinho do E") longo, enquanto o $\mathbf{E}$ das menores tem proporções alongadas e barra horizontal média mais curta [FIGURA 82].

FIGURA 79

Vocabulario

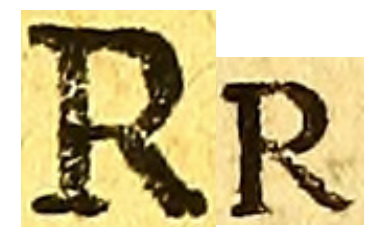

R com perna curta (18pt) e com a perna comprida (14pt).

80,81 e 82

Vocabulario

Manuale

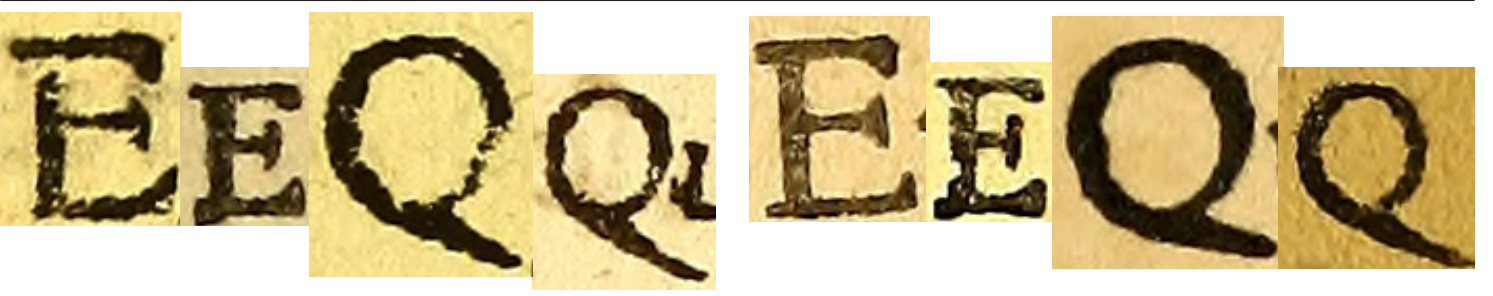

Caracteres de 18pt e 14pt no Vocabulario e no Manuale. 


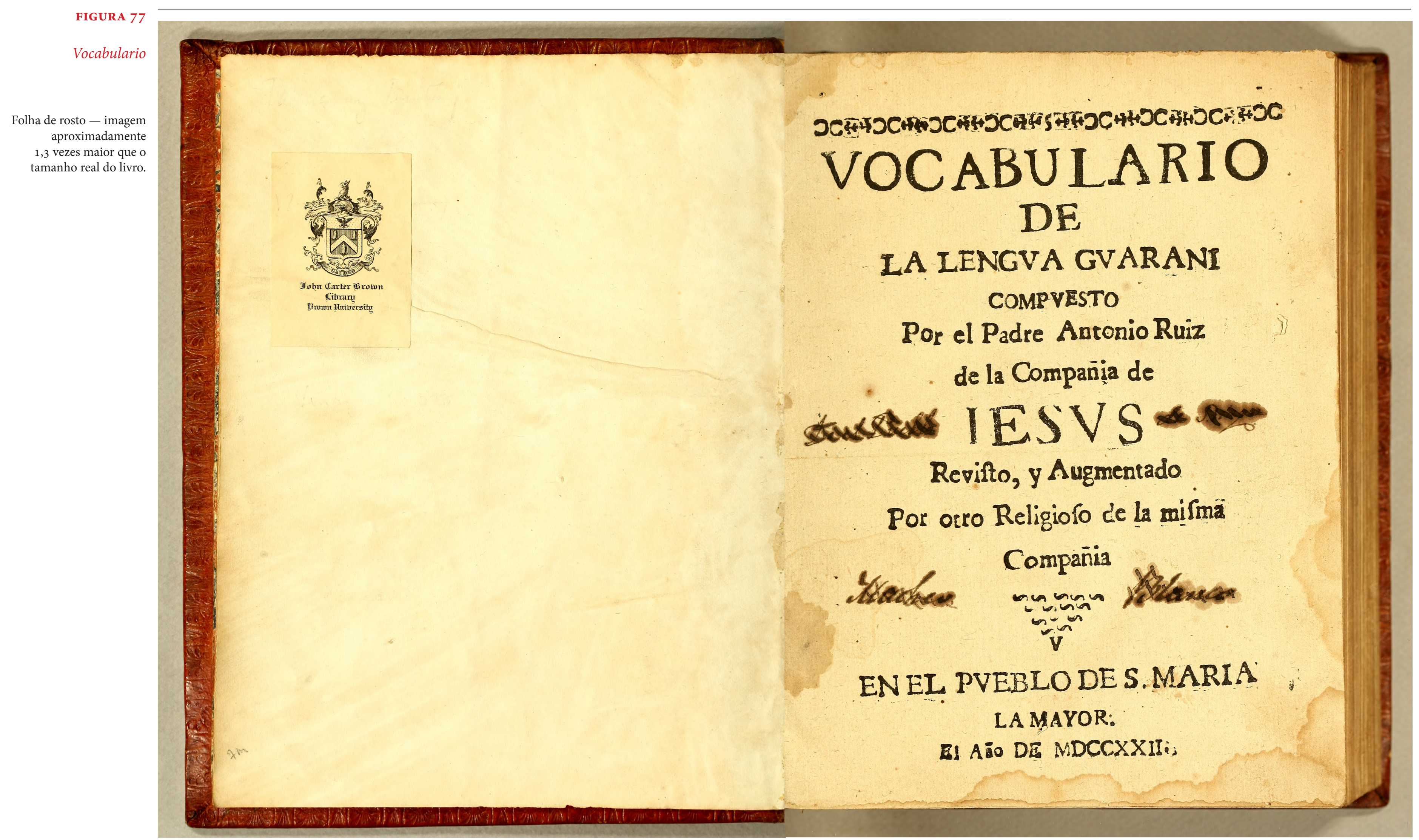




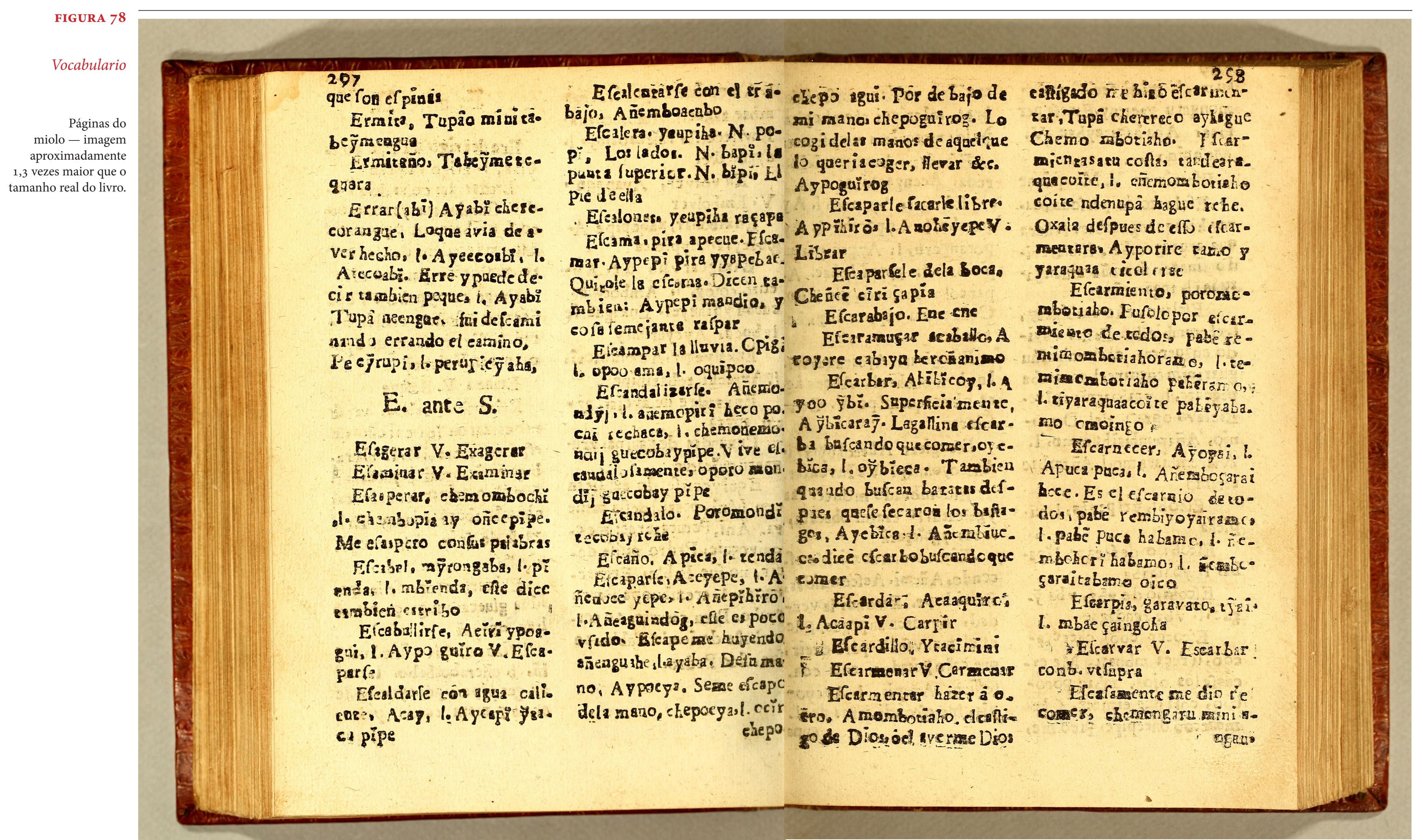


São então os mesmos tipos, usados em posições diferentes: a diferença entre o Manuale e o Vocabulario é que no Vocabulario o tipo alongado está na grande massa de texto do miolo e o tipo de proporções quadradas está apenas nas marcações de seções, enquanto que no Manual de Loreto o uso é inverso. Tudo aponta para o fato de que tanto em Loreto quanto em Santa Maria, estas duas fontes, disponíveis nos dois tamanhos, eram as mais abundantes e com conjunto de caracteres mais completo, para compor textos tão longos quanto este Vocabulario, de A a Z, com sinais de pontuação, parênteses, asteriscos, números e tudo mais.

Esta afirmação seria difícil se não fossem E, $\mathbf{R}$ e $\mathbf{Q}$ maiúsculos, com suas particularidades formais. Quase não há diferença, por exemplo, no desenho dos T's maiúsculos [FIGURA 83]. O a minúsculo poderia dar uma pista, pois as contraformas parecem mais abertas em um do que no outro [FIGURA 84], mas é difícil dizer se a percepção desta diferença se dá apenas porque sabemos, de antemão, das diferenças entre $\mathbf{E}, \mathbf{R}$ e $\mathbf{Q}$

\section{-}

Quase não há diferença nos desenhos dos T's maiúsculos (18pt e 14pt) e dos A's minúsculos (18pt e 14pt)

Observar as letras dos livros e reconhecer os tipos usados se torna uma tarefa ao mesmo tempo simples e complexa quanto mais as letras se repetem. Quanto maior o conjunto de letras olhadas e a possibilidade de compará-las, mas assertivas ficam as afirmações, pois os agrupamentos de caracteres segundo uma determinada característica crescem. Por exemplo, com as seiscentas páginas do Vocabulario, cresceu significativamente a quantidade de R's maiúsculos com perna longa. Isso parece deixar o grupo dos "R's de perna longa" mais coeso, se tomarmos em conta apenas este traço. Cria-se assim uma "identidade" para o grupo. Por outro lado, tornam-se também maiores as possibilidades de comparação e de reordenação segundo novas características, pois cada nova aparição de um determinado caractere é também uma nova possibilidade de compará-lo com outros.

Esta dificuldade / facilidade na observação dos tipos ocorre especialmente em relação aos tipos menores, e especialmente quando a quantidade de tinta usada na impressão varia muito. Obviamente não olhei um por um, todos os a's minúsculos nas seiscentas páginas do Vocabulario, e, se o tivesse feito, poderia encontrar entre eles novos desenhos, que suscitariam novas hipóteses sobre a produção desses livros, a julgar pela observação das capitulares, que maiores e mais fáceis de comparar, mostraram ser tão diversas entre si. Não tenho, entretanto, o objetivo de determinar a quantidade de fontes utilizadas na composição dos livros guaraníticos, o que me parece interessante é que, apesar das inúmeras diferenças internas, esteslivros acabam por formar um conjunto. Um conjunto original, cuja originalidade parece residir justamente na sua multiplicidade interna.

Na observação dos tipos menores, o que fiz foi olhar página por página buscando "boas" impressões de cada uma das letras do alfabeto, minúsculas e maiúsculas, itálicas e romanas, com e sem diacríticos, para formar um "conjunto de caracteres utilizados" no corpo do texto. "Boas impressões" considerei aquelas com menos tinta, em que é possível ver claramente o contorno de cada caractere. Para cada um dos livros, isolei um "conjunto de caracteres utilizado no miolo". Como os tipos maiores são menos abundantes, pude isolar todas as suas ocorrências. Repeti este procedimento para cada um dos livros. Assim, para cada um dos livros nós dispomos de: 1) um conjunto completo de caracteres do miolo; 2) todas as recorrências de caracteres maiores do que aqueles do miolo.

Esta impressão do Vocabulario de la lengua guarani [...] não é boa, novamente vemos as variações na quantidade de tinta que percebemos no Instruccion practica [...], o que novamente dificulta falar dos detalhes dessas letras menores, das serifas, das contraformas. Além disso, há pouquíssimas letras grandes no Vocabulario, são só as letras grandes da folha de rosto e três capitulares em todo o miolo. Também não há itálicas. Este é um livro de composição bastante "monótona", poucas surpresas, apenas dois tamanhos, sempre romanas. Nos resta olhar mais detidamente a folha de rosto.

$$
\sim
$$

A folha de rosto do Vocabulario de la lengua guarani [...] está composta em tipos de quatro tamanhos. Dois menores (os mesmos do miolo) e dois maiores. As maiores têm o mesmo tamanho das letras grandes da folha de rosto do Manual de Loreto . Comparar tamanhos em livros diferentes exige muito cuidado, pois as análises foram feitas a partir de fotos das páginas, e nós não sabemos se todos os livros foram fotografados da mesma distância e com o mesmo zoom. Mas alguma aproximação é possível, porque sabemos o tamanho dos livros. Por isso, para fazer qualquer afirmação sobre a semelhança ou diferença no tamanho de letras entre livros diferentes, foi necessário redimensionar as imagens dos livros para o tamanho real.

Os caracteres grandes que se repetem na folha de rosto do Manuale e do Vocabulario são $\mathbf{A} \cdot \mathbf{U} \cdot \mathbf{L} \cdot \mathbf{E}$. Com exceção do $\mathbf{E}$, que é o mesmo nos dois livros [FIGURA 85], todos têm desenhos distintos. Os L's são diferentes nas proporções e serifas [Figura 86], o $\mathbf{U}$ do Vocabulario tem uma abertura maior que o $\mathbf{U}$ do Manual de Loreto [Figura 87], os A's tem alturas diferentes de barra [FIGURA 88]. 
Mesmo comparando as letras grandes da folha de rosto do Vocabulario com aquelas no miolo do Manual, as diferenças não param, estas letras grandes do Vocabulario são, de fato, novas letras. Os A's do Manual de Loreto eram de três tipos: um tipo mais alongado, outro mais largo, um terceiro com a serifa "quebrada". Um dos A's do Vocabulario parece ser do mesmo tipo que os alongados do Manual, o outro, apesar de estar bem borrado, não se parece com nenhum, pois tem a barra mais alta que os demais [FIGURA 89]. O mesmo acontece com os $\mathbf{S}$ 's, além de serem diferentes entre si, nada tem a ver com os S's capitulares no Manuale [FIgURA 9o].

Os dois Os da folha de rosto do Vocabulario também são diferentes entre si [FIGURA 91], já os V's parecem ser do mesmo tipo [FIGURA 92]. Há dois I's, mas um está muito apagado, o que dificulta qualquer comparação [FIGURA 93].

Dentre todas as letras, as que me chamam mais atenção pela peculiaridade do desenho são o $\mathbf{B}$ e o R, que parecem aparentados entre si, pelo tratamento do traço, bastante reto, e pelas proporções semelhantes, com o bojo alto e estreitos [FIGURA 94]. Estas letras jamais se repetirão nos livros guaraníticos. Se o $\mathbf{Q}$ maneirista da folha de rosto do Manual de Loreto dava aquele livro um sabor especial - aquele $\mathbf{Q}$ também nunca mais aparecerá nos livros das missões - , aqui o $\mathbf{B}$ e o $\mathbf{R}$ cumprem esta função.

Dentre as capitulares do Vocabulario, duas são do tamanho das maiores letras da folha de rosto - um $\mathbf{C}$ e um $\mathbf{P}$ - a terceira é um P, maior que todas as outras letras do livro [Figura 95]. No Manuale ad usum patrum [...] havia Ps capitulares deste mesmo tamanho. Entretanto, este $\mathbf{P}$ não parece ser nenhum dos $\mathbf{P}$ 's capitulares do Manual.

No Manual de Loreto eram três tipos de P: a maioria tinha o mesmo desenho, havia um único com o traço do bojo mais fino e um outro com serifas apoiadas suavemente na haste. Este $\mathbf{P}$ capitular do Vocabulario, tem serifas diferentes de todos os outros. São serifas triangulares. Seria um quarto tipo de P. As suas proporções também não coincidem com as de nenhum dos Ps que vimos até agora. Este $\mathbf{P}$ grande do Vocabulario tem o bojo mais fino e mais curto. Pode até ser que esta seja uma
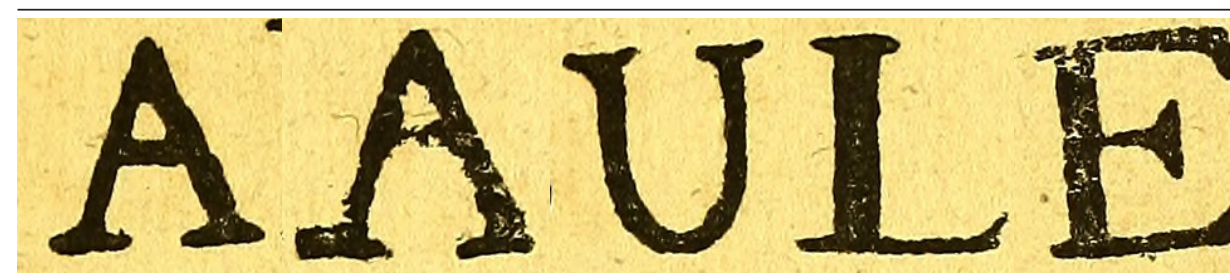

$85 / 86 / 87$

Vocabulario Manuale

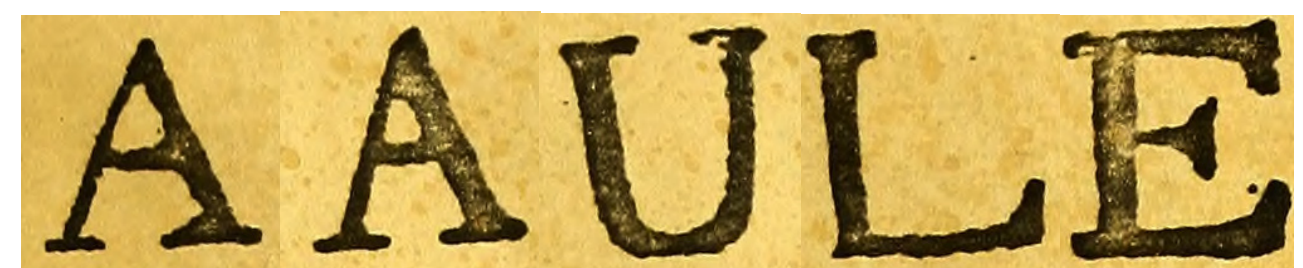

Caracteres grandes que se repetem na folha de rosto do Vocabulario e do Manuale. versão com menos tinta de um dos Ps do Manual, que também se diferenciava pelas serifas, mas é difícil ter certeza. O que se pode dizer com certeza é que até agora apareceram, no mínimo, três tipos de $\mathbf{P}$ capitulares, no máximo quatro. Todos do mesmo tamanho. [FIGURA 96]

FIGURA 88

Vocabulario

Manuale

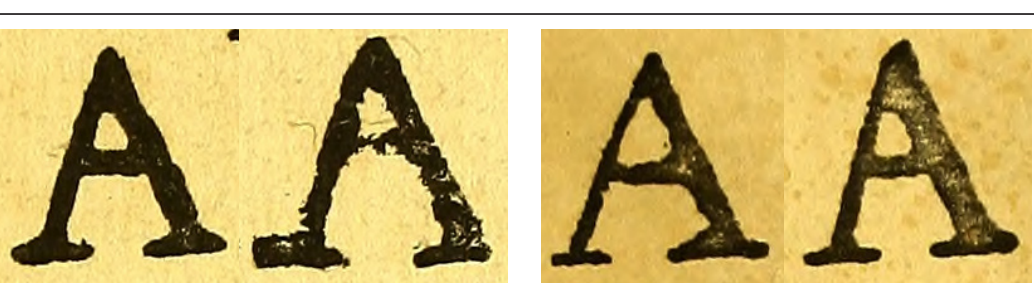

A's nas folhas de rosto do Vocabulario e do Manuale.

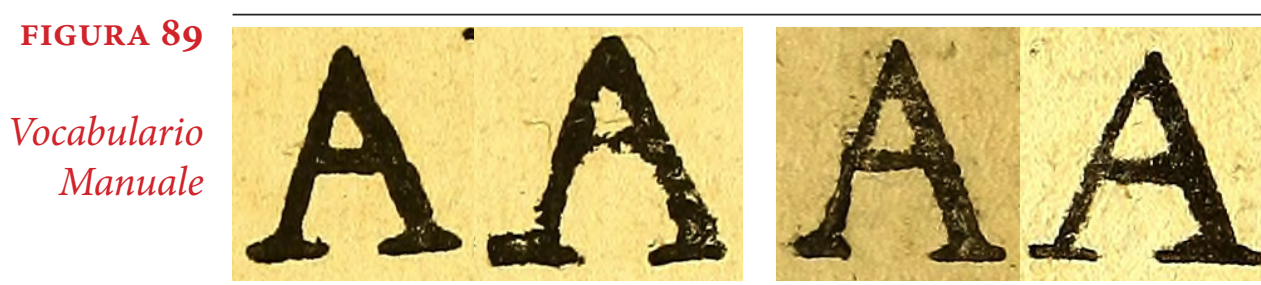

A's na folha de rosto do Vocabulario e no miolo do Manuale.

FIGURA 90

Vocabulario

Manuale

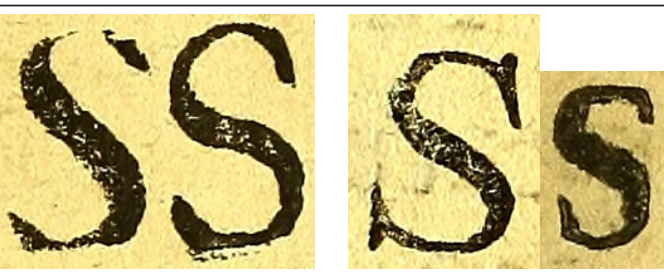

S's na folha de rosto do Vocabulario e no miolo do Manuale.

$91 / 92 / 93$

Vocabulario

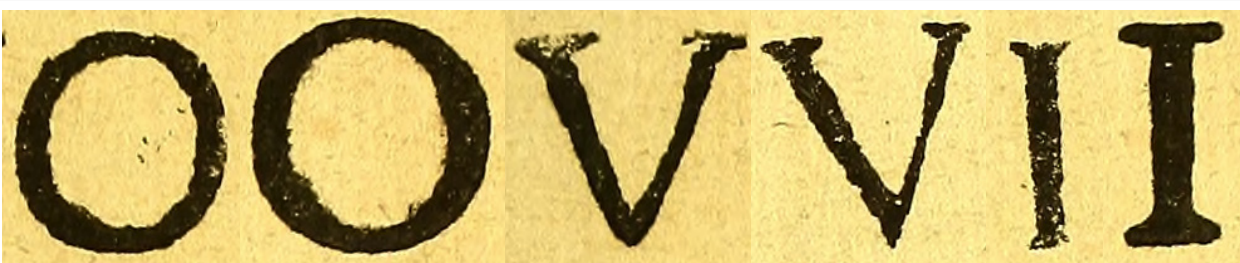

O's, V's e I's na folha de rosto.
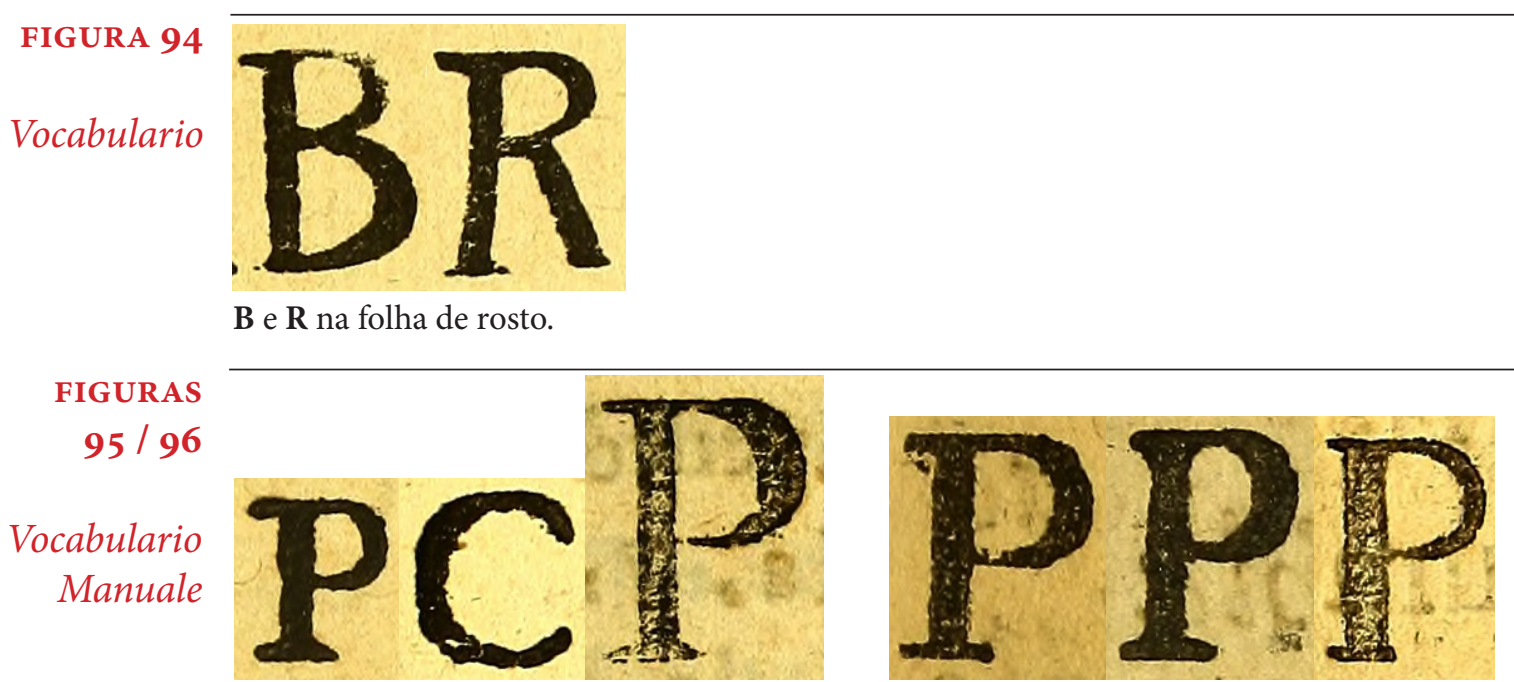

Capitulares do Vocabulario, e três desenhos de P's nas capitulares do Manuale. 
ARTE DE LA LENGUA GUARANI POR EL PADRE ANTONIO RUIZ DE Montoya DE LA COMPAÑIA DE JESUS Con los Escolios Anotaciones y Apendices DEL P. PAULO RESTIVO de la misma Compañia, Sacados de los papeles DEL P. SIMON BANDINI y de otros. En el Pueblo de S. MARIA La Mayor. El AÑO de el Señor MDCCXXIV.

Dois anos depois de imprimir o Vocabulario de la lengua guarani [...] a tipografia de Santa Maria la Mayor imprimiu o Arte de la lengua guarani [...], outro livro em quarto, com $21 \mathrm{~cm}$ [FIGURA $97 \cdot$ PP 96-97] [ FIGURA $98 \cdot$ PP 98-99].

Novamente o livro está composto num tipo pequeno, o mesmo que vimos no Vocabulario mas aqui as itálicas voltam a aparecer. Sobre elas, que ainda não tinham aparecido neste tamanho, a primeira vista é difícil dizer se são as itálicas do Manual de Loreto em um tamanho menor ou se têm outro desenho. Comparando as itálica minúsculas dois dois livros, tendo a achar que cada tamanho tem um desenho. Po exemplo, aqui encontramos $\boldsymbol{v}$ 's minúsculos itálicos de dois tipos: um caudal e outro não. Os dois são diferentes do que vimos no Manuale. [FIGURA 99]

Vemos diferenças também entre os $z$ 's caudais e na ligadura $c t$. A eitza, $\mathcal{U}$, confirma de uma vez por todas que não são as mesmas itálicas [FIGURA 10o]. É mais difícil localizar estas diferenças em caracteres mais "discretos", cujas características não são tão marcantes, como as minúsculas $\boldsymbol{b} \cdot \boldsymbol{a} \cdot \boldsymbol{h} \cdot \boldsymbol{n} \cdot \boldsymbol{d}$ [FIGURA 101]. Ainda assim, olhando com cuidado podemos perceber algumas diferenças, o $\boldsymbol{b}$ do Arte tem o bojo mais estreito que o do Manuale [FIGURA 102], o $\boldsymbol{e}$ tem contraformas bem diferentes [FIGURA 103] e o $r$ é menos inclinado [FIGURA 104].

As maiúsculas também confirmam que são dois conjuntos de itálicas diferentes, ou seja, além do tamanho ser diferente, o desenho é diferente: No Manuale o $\boldsymbol{B}$ é caudal, no Arte não [Figura 105]. O $\boldsymbol{N}$ e o $\boldsymbol{E}$ do Manuale têm proporções quadradas, enquanto que no Arte eles têm proporções alongadas [FIGURA 106]. $\mathcal{Q}$ e $\boldsymbol{R}$ têm caudas e pernas com desenhos diferentes [FIGURA 107].

Quanto ao tipo romano usado no miolo, este do Arte é o mesmo do Vocabulario. Também se repete o uso das letras de 30 pontos do Manuale para as aberturas de seções. Com uma novidade interessante: ao elegante conjunto de caracteres usados no miolo do Manual de Loreto e nas aberturas de seções do Vocabulario é acrescentado o U maiúsculo. O U sempre faltava neste conjunto, tanto no Manual de Loreto quanto no Vocabulario. Agora aparecem três U's maiúsculos: dois estão na folha de rosto, um está no miolo e cada um dos três tem um desenho diferente [FIGURA 108]. Talvez, por não haver U's maiúsculos nesta fonte, tenha sido necessário

\section{ขvข}

FIGURA 100 Manuale

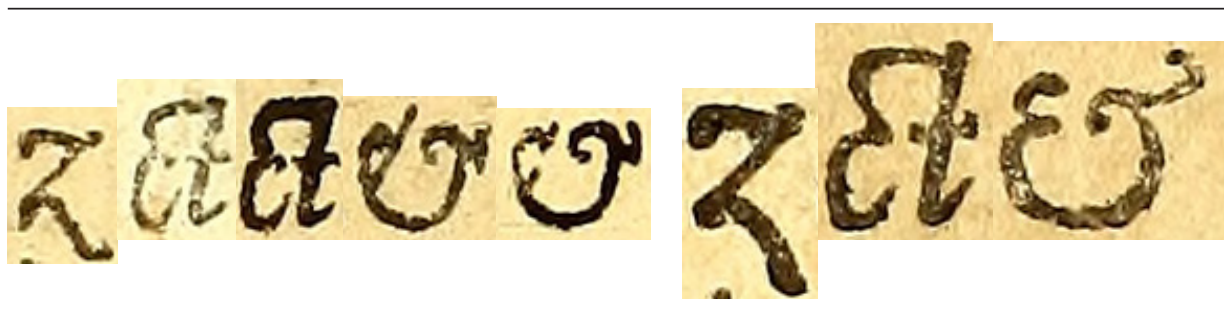

$z \cdot c t \cdot \&$ de $14 \mathrm{pt}$ no Arte e de $18 \mathrm{pt}$ no Manuale.

FIGURA 101

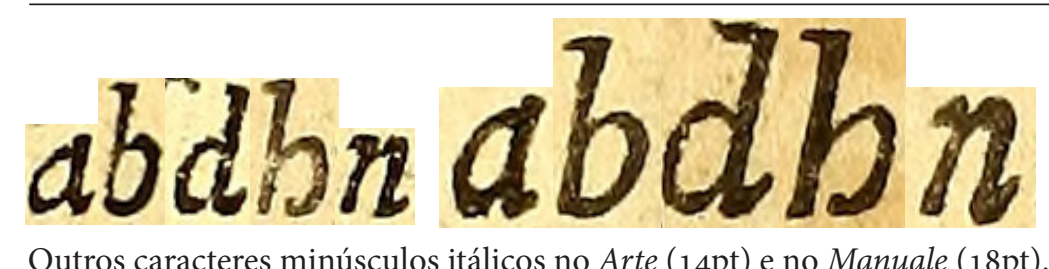

Outros caracteres minúsculos itálicos no Arte (14pt) e no Manuale (18pt).

FIGURAS
$2 / 103 / 104$

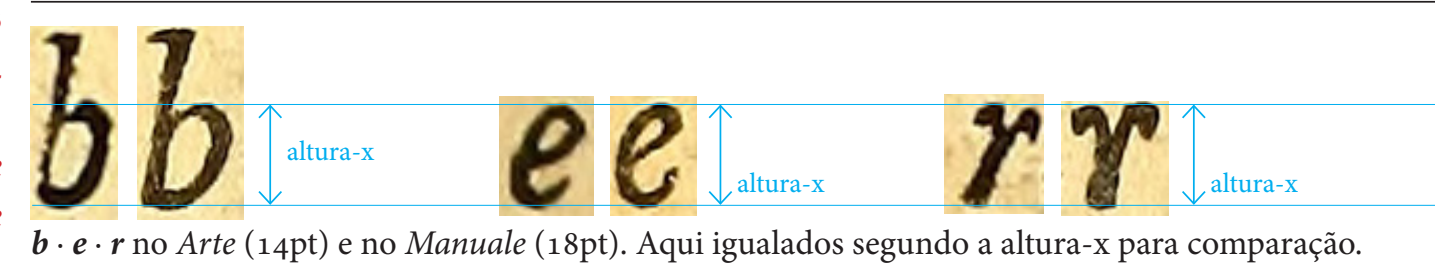

FIGURA 105

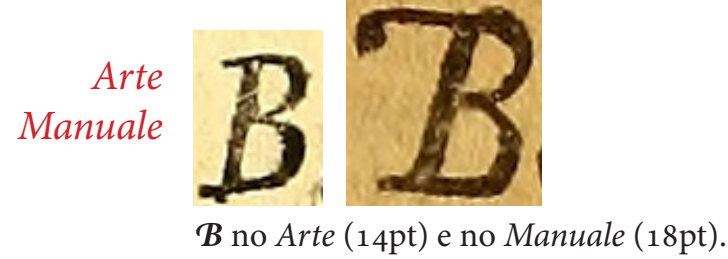

FIGURA 106

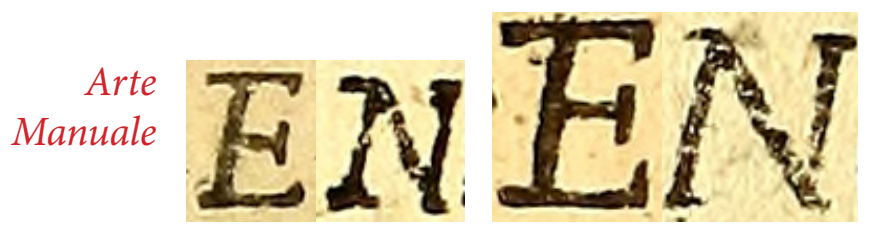

E e N no Arte (14pt) e no Manuale (18pt). Diferença nas proporçoes: os primeiros mais alongados, os segundos mais quadrados.

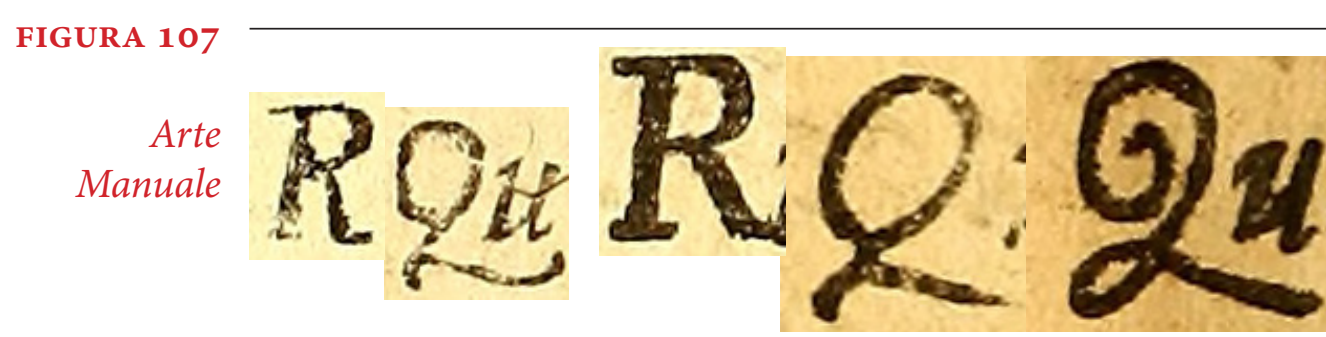

$\boldsymbol{R}$ e $\mathbf{Q}$ no Arte (14pt) e no Manuale (18pt). Diferença nos desenhos da perna do $\mathbf{R}$ e cauda do $\mathcal{Q}$

FIGURA 108

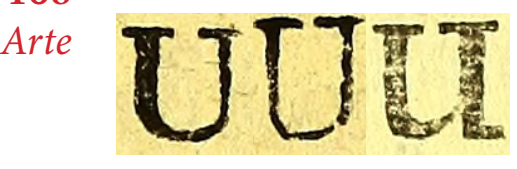

U na folha de rosto (dois primeiros) e no miolo (na ponta direita), todos de 18pt. 
Folha de rosto - imagem

\section{$2 \mathrm{maritcl}$}

Guarani. RUIZ DE MONTOYA (Antonio) Tesoro DE LA LENGUA GUaRANI .. Colophon: Con Privilegio. En Madrid. Por Iuan Sanchez made up in facsimile, in all other respects a fine sound and of the title in the original limp vellum wraper Colcation: 8 preliminary leaves; $1-407$ numbered leaves; and leaf of Colophon. EXCESSI VELY RARE, as well as important for the study of South American linguistics.
The alphabet is Guarani-Spanish. The author published in the following year Arte with the Spanish-Guarani vocabulary, of

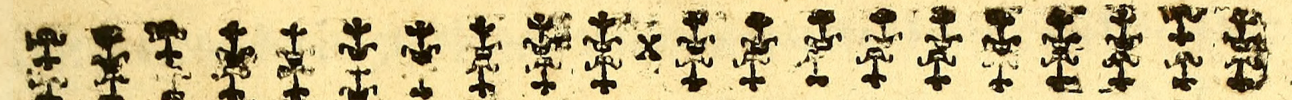

\section{ARTE}

DEL A LENGUAGUARANI

POREI P.ANTONIORUIZ D $\mathrm{E}$

Mont oya

DELA COMPAN $I A$

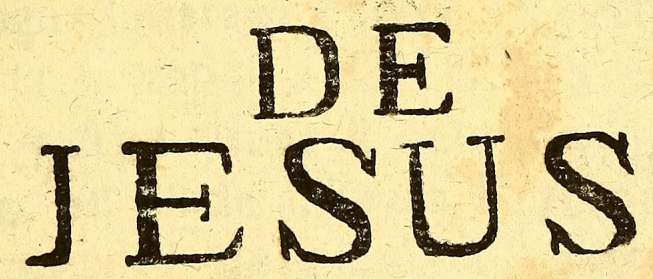

Con los Efcolios Anotaciones y Apendices

DEL P. PAULO RESTIVO de la mifma Compañia Sacados de los papeles

DEL P.SIMON B AIJDINI $y$ de otros.

Enel Pueblo de S. MARIA La Mayor. El AÑO di el Señor MDCCXXIV = 


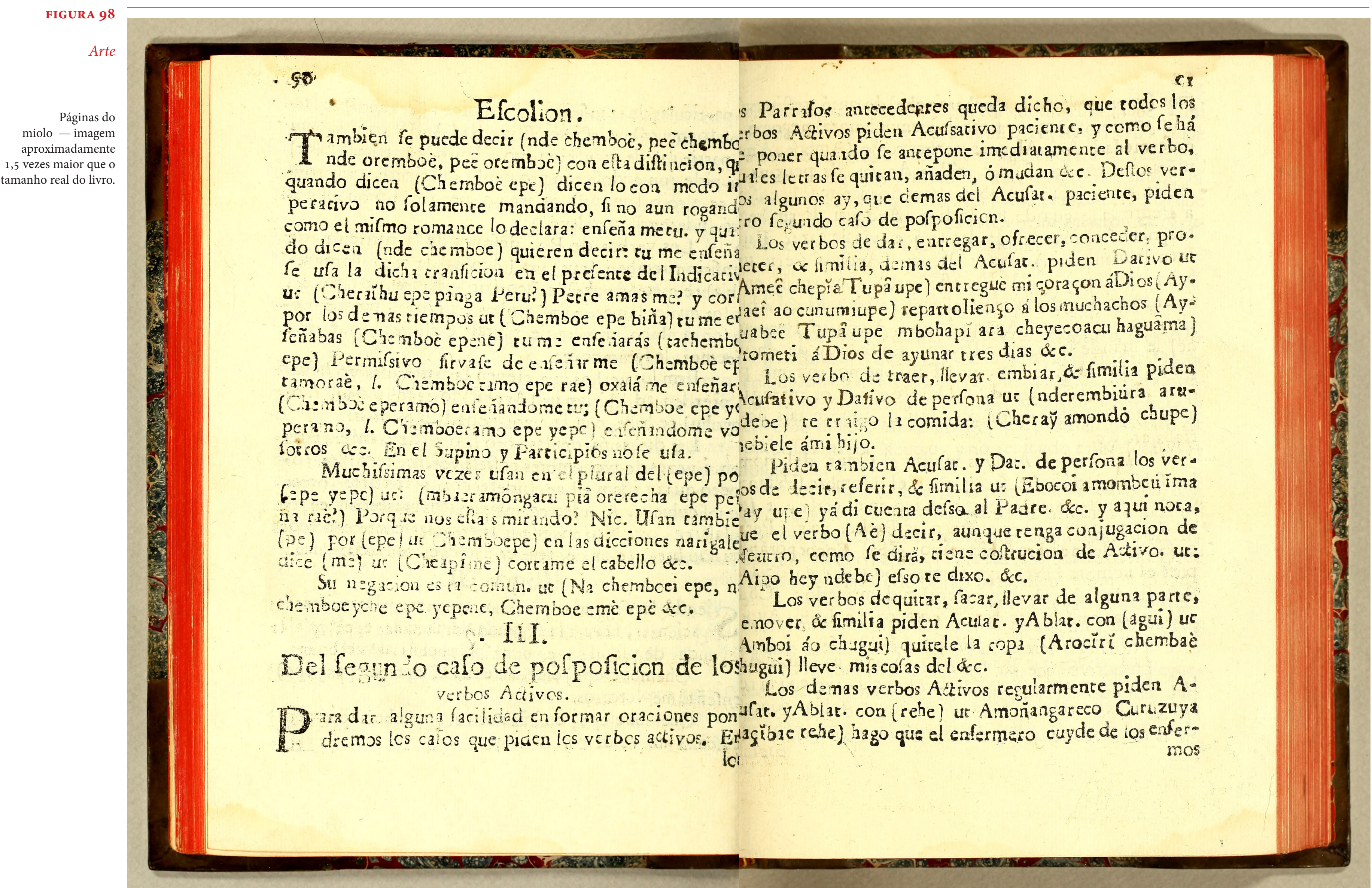


acrescentá-lo para a impressão deste livro. Mas porque aparecem três desenhos diferentes? Se os tipos eram fundidos nas missões, porque fundiriam U's com três desenhos diferentes?

$$
\sim
$$

Além das itálicas, também as letras grandes voltam a aparecer em abundância no Arte de la lengua guarani [...]. Há muitas capitulares por todo o miolo e algumas letras grandes na página 117, abrindo o capítulo "Particulas de la lengua guarani". As capitulares têm dois tamanhos, que coincidem, mais ou menos, com os dois tamanhos maiores da folha de rosto. $\mathrm{E}$ as letras que abrem o "Particulas de la lengua guarani" têm um tamanho que coincide também com o tamanho menor das letra grandes da folha de rosto. Lembro, entretanto, que tamanhos semelhantes não sig nificam desenhos semelhantes. Neste livro também os desenhos de tipos variam, no mesmo tamanho e entre tamanhos.

Os T's grandes aparecem bastante, sempre nos dois tamanhos mencionados. Os menores aparecem em dois desenhos: um tem serifas de base retas, o outro tem serifas de base triangular. Os maiores aparecem sempre com o mesmo desenho [FIGURA 109]

Os C's também são de dois tamanhos. Os menores aparecem sempre com o mesmo desenho, os maiores têm dois desenhos diferentes: um tipo é mais redondo, o outro é mais oval. O tamanho das aberturas e forma dos terminais também são diferentes [FIGURA 110]. No Manual de Loreto havia C's de dois tamanhos, uns muito grandes, bem maiores que estes, e um único pequeno, que talvez tenha o mesmo desenho dos C's menores que vemos aqui. A diferença na quantidade de tinta nos impede de fazer uma comparação mais certeira dos tamanhos. [FIGURA 111]

Os M's também aparecem em dois tamanhos diferentes [FIGURA 112]. O tamanho maior tem o mesmo tamanho do $\mathbf{M}$ que vimos na folha de rosto do Manuale. Os desenhos são muito parecidos mais não são iguais: este $\mathbf{M}$ do Vocabulário tem serifas finas e o vértice inferior mais longo, enquanto $\mathrm{o} \mathbf{M}$ da folha de rosto do Manuale tem serifas mais grossas e o vértice inferior mais curto. $\mathrm{O} M$ menor também tem um desenho próprio, com vértice inferior que vai até a linha de base, serifas mais curtas e proporções alongadas.

Os D's capitulares do Vocabulario também aparecem em dois tamanhos diferentes. O maior já vimos no Manual de Loreto, entre as capitulares, mas o menor tem outro desenho, mais alongado [FIGURA 113].

Os L's e E's, aparecem em abundância e, assim, aparecem mais diferenças de tamanho e de desenho entre eles, inclusive diferença nos desenhos num mesmo tamanho.
FIGURA 109

\section{TTT}

T's maiúsculos nos dois tamanhos grandes. Os maiores aparece sempre com este desenho, os menore aparecem com serifas triangulares e, uma vez (na página 117 do Arte), aparece com serifas retas.

FIGURA 110

Arte

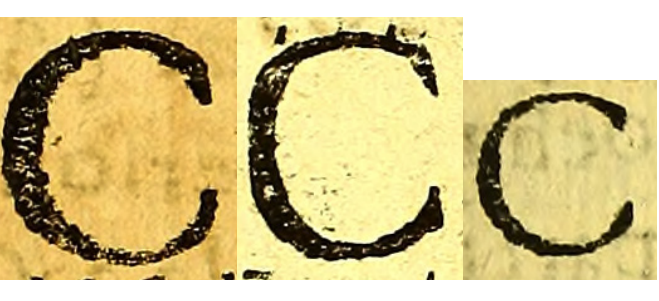

C's maiúsculos nos dois tamanhos grandes. Os maiores aparecem com dois desenhos, um mais redondo outro mais oval.

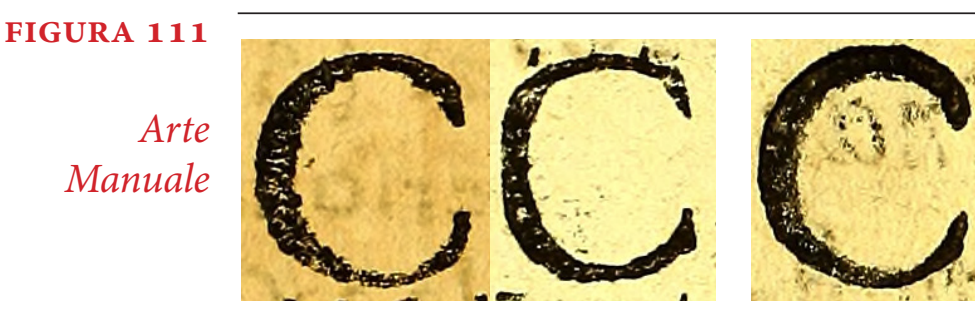

Comparação dos C's que coincidem em tamanho no Arte e no Manuale.

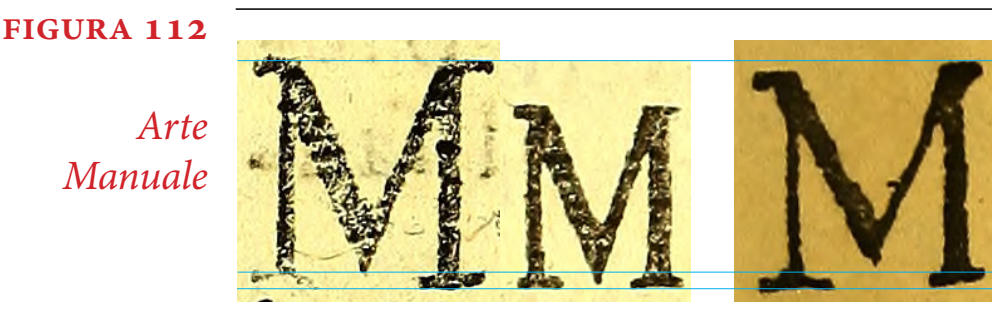

M's grandes em dois tamanhos no Arte, e na folha de rosto do Manuale.

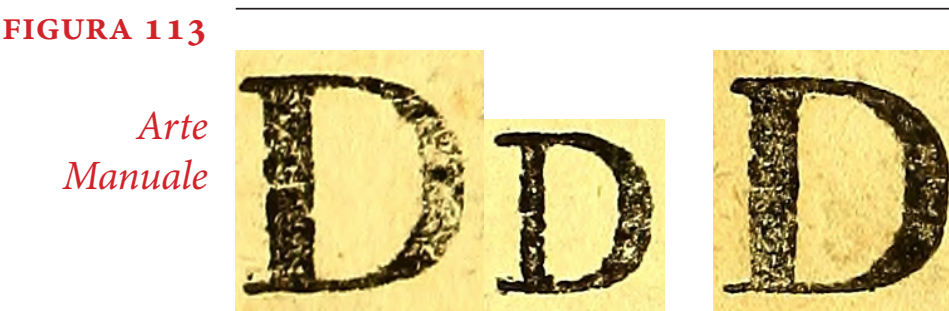

D's grandes em dois tamanhos no Arte. O maior foi visto antes, entre as capitulares do Manuale. 
São vinte e dois L's, de dois tamanhos diferentes. Dentre os maiores há dois desenhos, um é mais quadrado, outro é mais alongado [FIGURA 114]. O mais quadrado não é o mesmo da folha de rosto do Manual de Loreto, pois, ainda que as proporções sejam as mesmas, este do Arte tem serifas de topo mais finas [FIGURA 115]. O outro, por ter proporções alongadas, se assemelham ao $\mathbf{L}$ da folha de rosto do Vocabulario, mas comparando a espessura das hastes e serifas, vemos que os desenhos são diferentes. Um tem a haste mais espessa, serifas maiores no topo e na base e acabamento curvo da terminal. O outro tem a haste mais fina, serifas menores e terminal reto [FIGURA 116].

Dentre os L's do tamanho menor, também há diferença no desenho, um desenho mais alongado, outro mais quadrado [FIGURA 117].

São trinta e oito E's, em três tamanhos diferentes, e com desenhos diferentes em um mesmo tamanho. Dentre os maiores há no mínimo três desenhos [FIGURA 118] Vê-se a diferença entre eles pelo desenho da barra horizontal (o "tracinho do E"): em um desenho a barra é mais longa e tem serifas retas, no outro ela é mais curta e as serifas são triangulares, no terceiro desenho o traço da barra é mais grosso e, além disso, as serifas são mais longas [FIGURA 119]. Dentre os tamanhos menores, a diferença se dá na altura da barra horizontal. São dois desenhos: um tem a barra mais alta, o outro tem a barra mais baixa [FIGURA 120]. É interessante notar que os três desenhos que vemos no tamanho maior e no tamanho menor, também não coincidem entre si. Ou seja, não são os mesmos três tipos em dois tamanhos diferentes, mas, no limite, cinco fontes diferentes!

O E de tamanho mediano ocorre apenas uma vez e é uma versão maior daquele de um dos menores [FIGURA 121].

Também há S's capitulares em dois tamanhos, cada tamanho com um desenho. O S maior tem o mesmo desenho daqueles que vimos entre as capitulares do Manual de Loreto [FIGURA 123]. Lembro que no Manuale vimos um S "perdido", que aparecia entre as capitulares com um tamanho menor e desenho diferente. No Arte ele não reaparece, apesar de ter o mesmo tamanho que os $\mathbf{S}$ 's capitulares menores deste livro, ele continua com um desenho diferente de todos os $\mathbf{S}$ 's grandes que vimos até agora [FIGURA 124].

Os P's capitulares do Arte têm, mais uma vez, dois tamanhos. Cada tamanho tem um desenho, mas não há variações no desenho de um mesmo tamanho [FIGURA 125]. Lembremos que no Manuale havia muitos $P^{\prime}$ 's, com desenhos diferentes num mesmo tamanho. Os P's maiores que vemos aqui são do mesmo tamanho dos P's maiores que vimos no Manual, apesar disso e de também terem o traço do bojo mais fino, como um dos desenhos que vimos no Manuale, a largura das hastes não coincide [Figura 126]. Estes P's do Arte de la lengua guarani [...] têm um novo desenho.

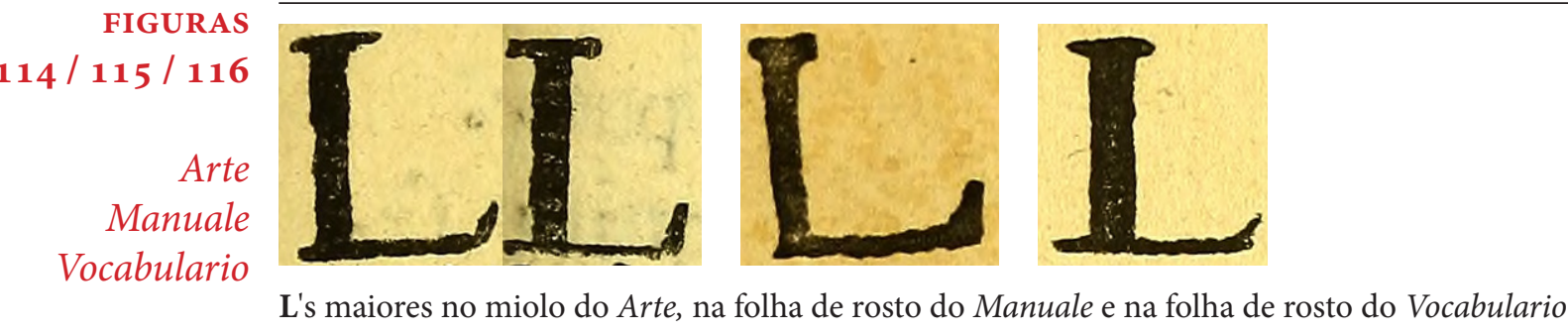

FIGURA 117

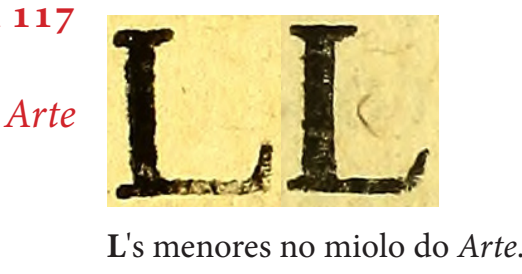

FIGURAS $118 / 119 / 120$

Arte

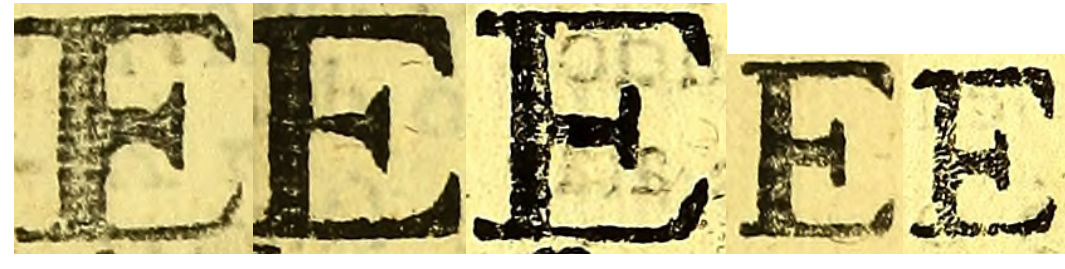

E's do tamanho grande maior (três desenhos distintos) e no tamanho grande menor (dois desenhos distintos).

FIGURA 121

Arte

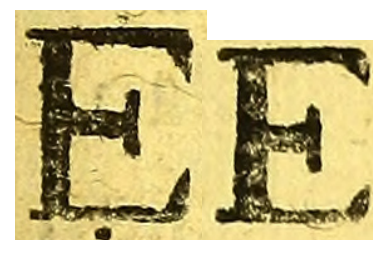

Única ocorrência de E grande neste tamanho, mediano (à esquerda); e E do tamanho grande menor (à direita).

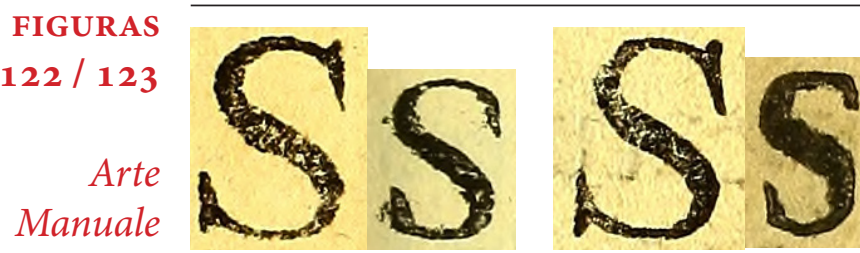

S em dois tamanhos no miolo do Arte e do Manuale. Os maiores tem o mesmo desenho, os menores não.

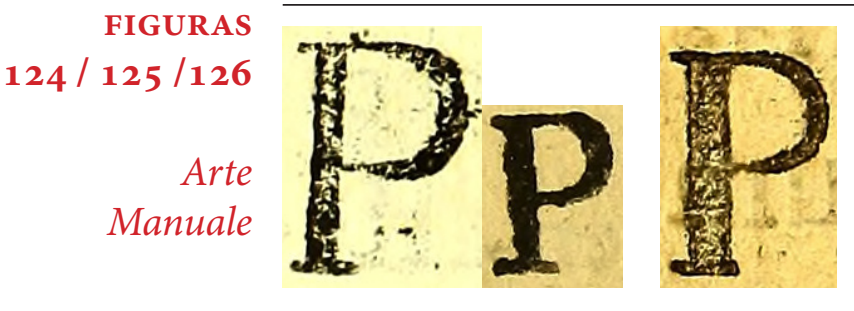

P em dois tamanhos no miolo do Arte. O maior tem o mesmo tamanho dos P's grandes do Manuale, mas desenhos diferentes. 


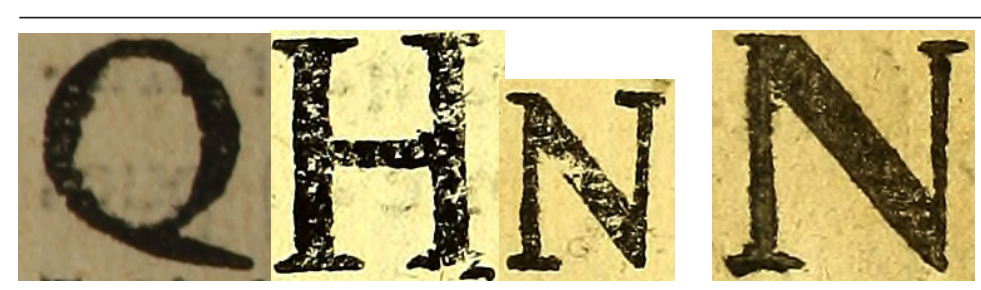

FIGURA 127

$\mathbf{Q} \cdot \mathbf{H} \cdot \mathbf{N}$ no Arte e $\mathbf{N}$ no Manuale.

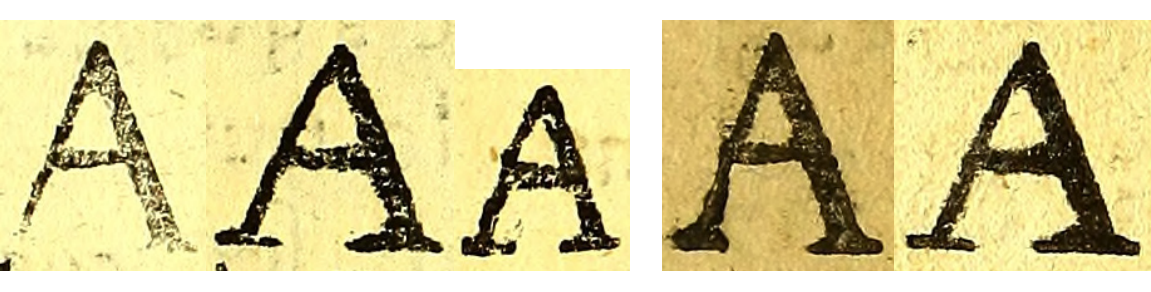

A's capitulares no Arte e no Manuale.

\section{AA}

FIGURA 129

A capitular no Arte (à esquerda) e A em abertura de capítulo na página 117 (à direita).

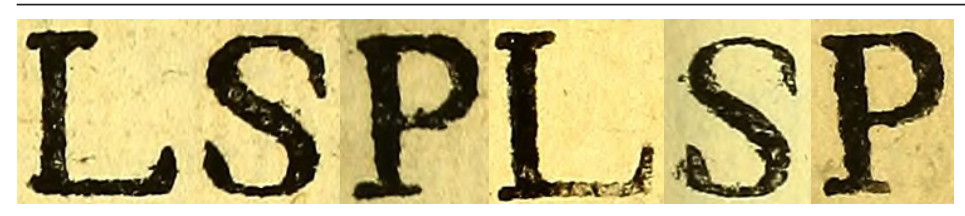

FIGURA 130

L·S · P na abertura de seção na página 117 (à esquerda) e entre as capitulares (à direita).
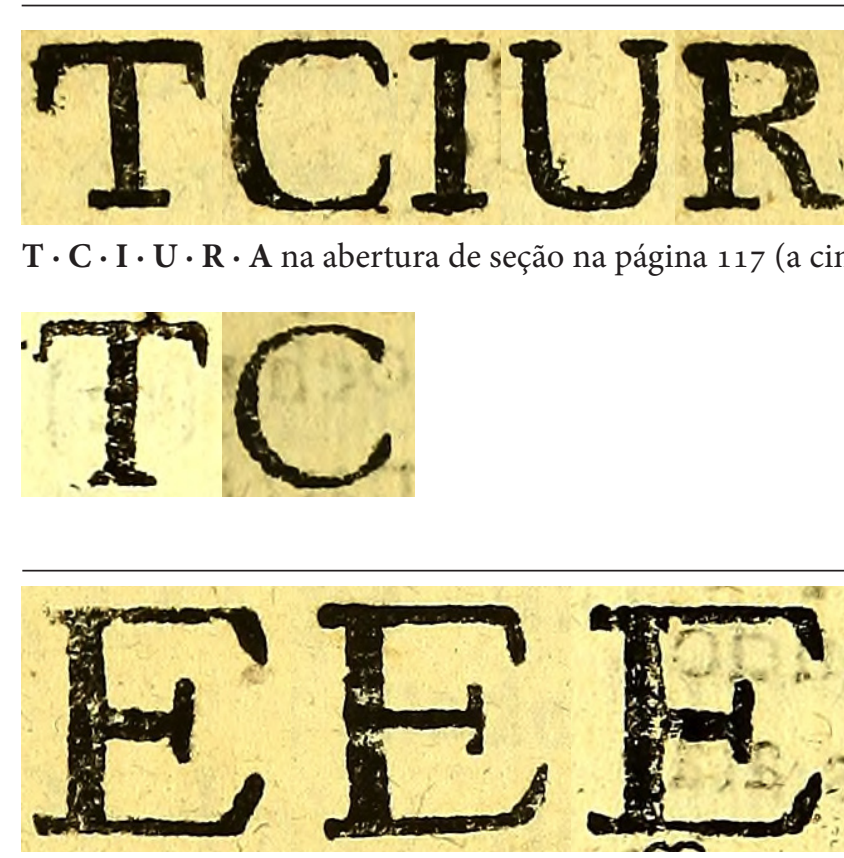

FIGURAS $133 / 134$
Há outras letras capitulares que aparecem menos: dois Q's, do mesmo tamanho e com o mesmo desenho, e um $\mathbf{H}$, o único $\mathbf{H}$ que vimos em tamanho grande até agora em todos os livros analisados. Por ser o único, não podemos compará-lo ainda. Há também um único $\mathbf{N}$, diferente em tamanho e em proporções dos N's que vimos antes, no Manuale [FIGURA 127].

Dentre as capitulares falta falar do A. São três A's, cada um de um tamanho, cada um com um desenho. Dois destes desenhos, os maiores, nós vimos antes, no Manual de Loreto [FIGURA 128]. Já o menor não havia aparecido ainda. Ele se parece mais com um dos A's que aparece na abertura de "Particulas de la lengua guarani”, na página 117 deste livro [FIGURA 129]. O conjunto de letras nesta abertura de capítulo é especial: com exceção de $\mathbf{L} \cdot \mathbf{S} \cdot \mathbf{P}$, que se parecem com $\mathbf{L} \cdot \mathbf{S} \cdot \mathbf{P}$ que vimos entre as capitulares [FIGURA 130], todas as demais: $\mathbf{T} \cdot \mathbf{C} \cdot \mathbf{I} \cdot \mathbf{U} \cdot \mathbf{R} \cdot \mathbf{A}$, são únicas. T e $\mathbf{C}$ podem ser comparadas com T's e C's que aparecem entre as capitulares, e são diferentes [FIGURA 131]. I • U • R são os únicos que aparecem neste tamanho em todos os livros que vimos até agora. Os dois A's são diferentes entre si: um tem a barra horizontal mais baixa, e se parece com uma capitular, como já apontei, o outro tem a barra horizontal mais alta [FIGURA 132].

Resta agora falar das letras grandes da folha de rosto, e compará-las com estas todas do miolo. Na folha de rosto do Arte de la lengua guarani [...], como na folha de rosto do Vocabulario, há dois tamanhos grandes e dois tamanhos pequenos, aliás isso se repetirá em todas as folhas de rosto impressas em Santa Maria: os dois tamanhos pequenos do miolo (aqueles que venho chamando de 18pt e 14pt) aparecerão na folha de rosto acompanhados de dois tamanhos grandes.

E novamente as diferenças aparecem entre as letras. Vemos logo que os dois E's da folha de rosto são diferentes: o tamanho das barras horizontais (o "tracinho do E”) não é o mesmo, um é mais curto que o outro [FIGURA 133]. O que tem a barra mais curta nós vimos antes, no miolo [FIGURA 134], o que tem a barra mais longa tem um novo desenho, que não vimos antes. Assim, neste livro há pelo menos 4 tipos de $\mathbf{E}$ neste tamanho grande [FIGURA 135]. Ressoa a pergunta que nos fizemos em Loreto: Se os tipos eram fundidos nas missões, porque estes Es são tão diferentes?

FIGURA 135

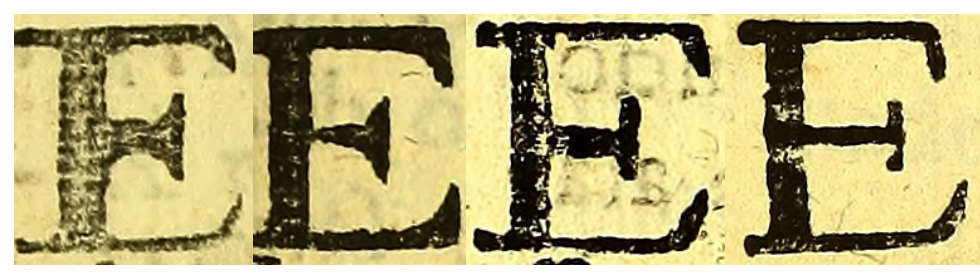

Quatro E's do mesmo tamanho no Arte. 
Cada vez que refazemos esta pergunta, ela nos sugere novas hipóteses. Se desconfiamos que em Loreto os tipos maiores, com seus muitos desenhos para um único caractere, no mesmo tamanho, não eram fundidos lá, ou pelo menos não eram todos fundidos lá, agora estamos falando de Santa Maria. Se desconfiamos que em Santa Maria os tipos menores não eram todos fundidos lá, pois pareceu estranho o acréscimo do $\mathbf{U}$ maiúsculo com três desenhos diferentes, agora a pergunta nos faz pensar que talvez os tipos maiores também não eram fundidos lá

E novas perguntas surgem: vemos que o $\mathbf{U}$ da folha de rosto deste livro tem um desenho próprio, que não vimos no Manuale ou no Vocabulario. É um terceiro desenho de U [FIGURA 136]. Que o U do Manual de Loreto não apareça aqui, em Santa Maria, poderia nos levar a pensar que em reduções diferentes novos tipos eram fundidos. Mas que o U do Vocabulario, impresso nesta mesma Redução, não apareça na impressão do Arte, reforça a hipótese de que, também em Santa Maria estes tipos estavam misturados e portanto eram utilizados sem distinção, e que talvez não fossem fundidos lá.

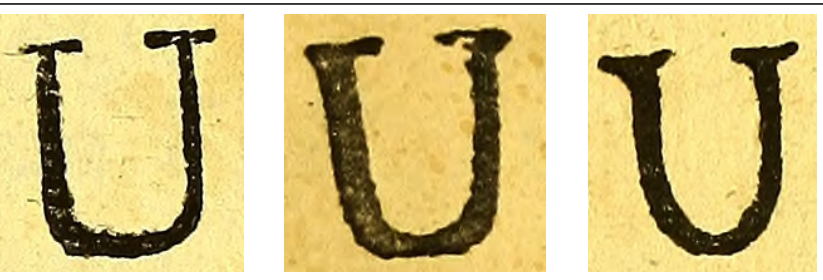

IGURA 136

U nas folhas de rosto do Arte, Manuale e Vocabulario

O desenho peculiar do $\mathbf{U}$ me fez olhar de outro jeito os demais caracteres da folha de rosto. Este $\mathbf{U}$ tem um traço um tanto irregular, que parece ora mais grosso, ora mais fino, e serifas "singelas" que parecem retas e improvisadas. Consigo ver estas mesmas características, ou "peculiaridades" em $\mathbf{A} \cdot \mathbf{T} \cdot \mathbf{R} \cdot \mathbf{J}$ e nos dois $\mathbf{S}$ 's [FIGURA 137]. Não é que sejam as mesmas serifas, ou a mesma espessura dos traços, mas estes caracteres compartilham entre si justamente uma inconstância nas formas. Além disso, são únicos, não há nada parecido com estas letras no miolo, entre as capitulares do mesmo tamanho. Se tanto no Vocabulario como no Manual de Loreto havia caracteres que davam um "sabor especial" ao livro - o $\mathcal{Q}$ maneirista do Manuale e o R e B retos do Vocabulario - me parece que no Arte estas letras "singelas" quase improvisadas, com irregulares na modulação do traço (o que vê-se marcadamente no R [FIGURA 138]), cumprem esta função. Veremos algumas destas letras se repetirem na folha de rosto do Explicacion de el catechismo [...], impresso no mesmo ano em Santa Maria la Mayor.
FIGURA 137

Arte

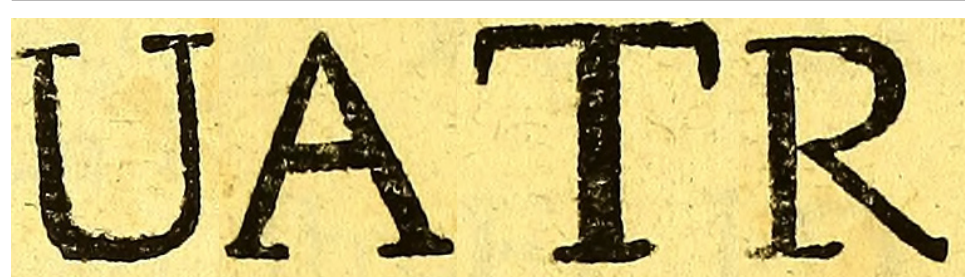

Caracteres da folha de rosto com serifas similares e irregularidades nos traços similares.

FIGURA 138

Arte

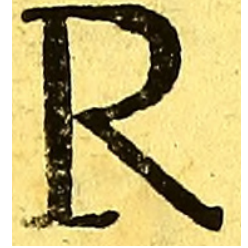

R na folha de rosto. Neste caractere é marcante a singeleza das serifas e irregularidade do traço.

EXPLICACION DE EL CATECHISMO EN LENGUA GUARANI POR NICOLAS YAPUGUAI CON DIRECTIONDEL P. PAULO RESTIVO DE LA COMPAÑIA DE JESUS En el Pueblo de $S$. MARIA La Mayor. Año de MDCCXXIV

O Explicacion de el catechismo [...], impresso em quarto, $23 \mathrm{~cm}$, fecha o ciclo de impressões em Santa Maria la Mayor [FIGURA $141 \cdot$ PP 108-109]. Não há muitas novidades em relação à composição. Vemos novamente os tipos menores, itálicos e romanos de $18 \mathrm{pt} \mathrm{e} 14 \mathrm{pt}$, usados no miolo [FIGURA 142 · PP 110-111]. Não tenho dúvidas de que estes tipos menores são os mesmos utilizados antes, com o mesmo "uso cruzado": os tipos alongados de 14pt compondo a maior parte do texto e o tipo de 18 pt e proporções quadradas, que vimos pela primeira vez no Manual de Loreto, compondo as aberturas de seções.

Como no Arte de la lengua guarani [...], vemos o acréscimo do U maiúsculo ao conjunto de caracteres em $18 \mathrm{pt}$. Vemos dois destes U's na folha de rosto, com o mesmo desenho daqueles do Arte, e há um terceiro ainda, no miolo, com um novo desenho [FIGURA 143].

A folha de rosto do Explicacion del catechismo [...] tem a mesma configuração das folhas de rosto do Vocabulario e do Arte: são letras de quatro tamanhos, dois tamanhos grandes e dois tamanhos menores. Os tipos menores da folha de rosto são os mesmos tipos usados no miolo, como nos demais livros da gráfica de Santa Maria. Mas há uma novidade notável: o Explicacion traz uma gravura. Aliás,

FIGURA 143 Explicacion

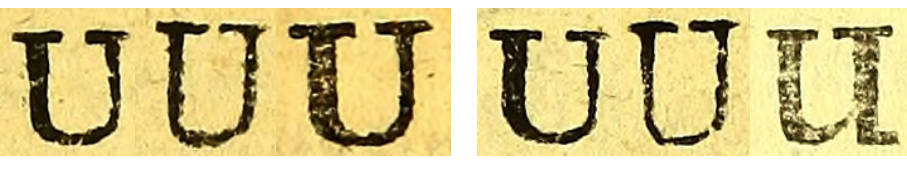

Uno Sermones: os dois mais a esquerda são da folha de rosto, o terceiro é do miolo; E no Arte: os dois mais a esquerda são da folha de rosto, o terceiro é do miolo, todos de $18 \mathrm{pt}$. 


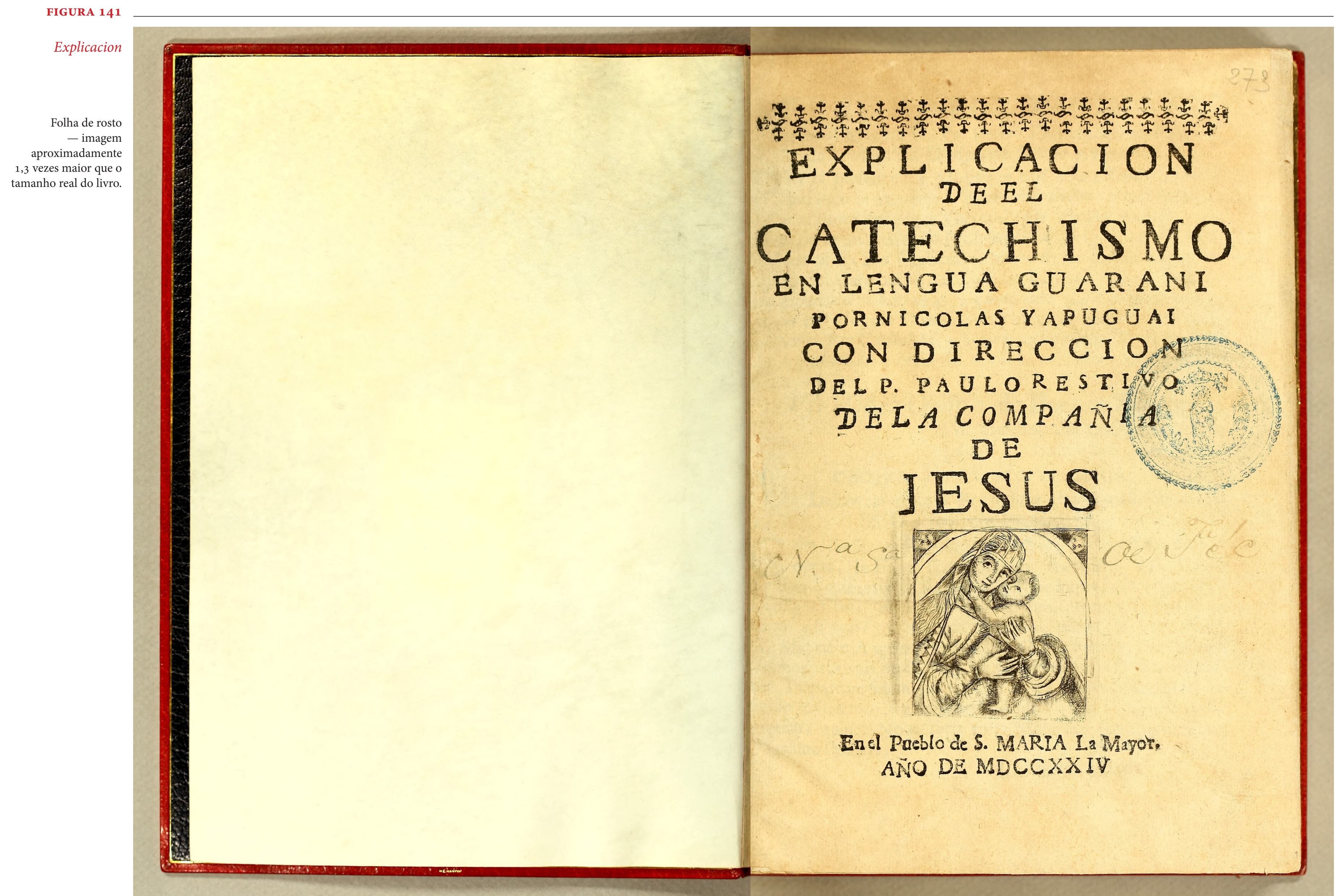


FIGURA 142

Explicacion

P. hias

P. Ha acoi recoaci teríó noōngabucupe añ yepe cic ig aete yahecha miri yposeaha ba ambuac.

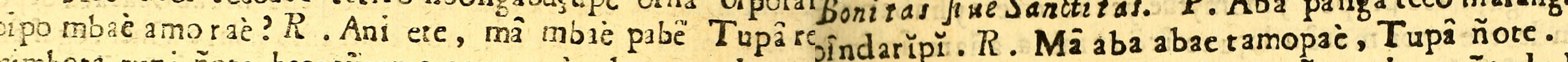

mimbota rupi ñote hecoejuramo ramo paè mbae amo hece j $\mathrm{p}$. A ñebé nipo teco marângatu ñote oipora ñande hereco ugite?.

作

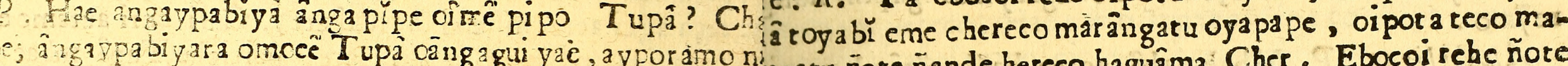
Tupa apepe año yepe neicoi a - Anicico yepe sn a ñandebe teco marângatu pabẽ mboye hu buea babamo

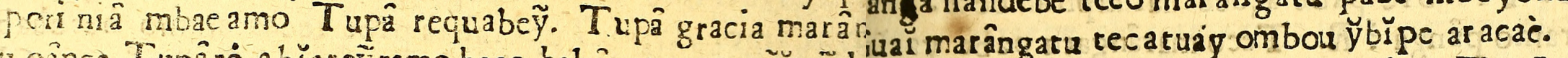

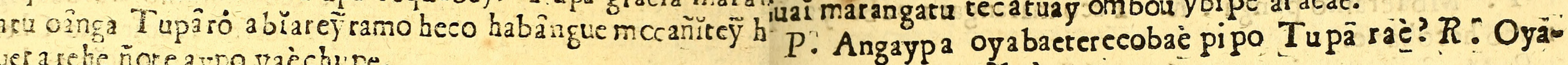
ger a rehe note aypo yaçchupe.

Sapientia $P$. Oñemi pânga mbaè amo Tupā teccqỉaaha aguarae? R. Noñemiy, opacatu mble y̆ma ete guraresa hecohape, hae ñande ânga rupiareteramo hecohaperano:

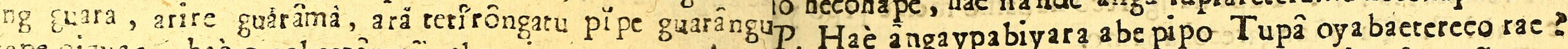

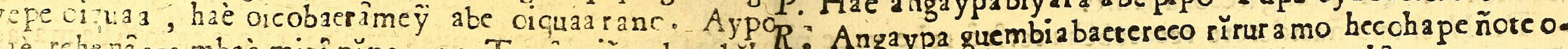

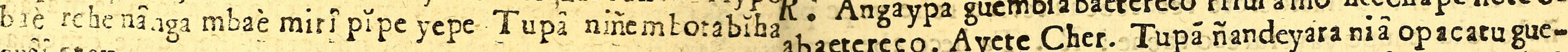
uầं crey. Tae egli ñemih ape nande yepiácrecoha upe yére pâno limoñanguera ndoyabaeterecoi, ohăhu catu, hae aete mbae

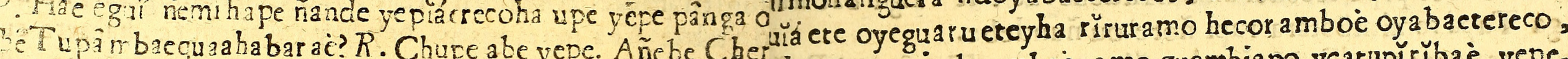
ufànaéba âng a cochepì ara amo rer

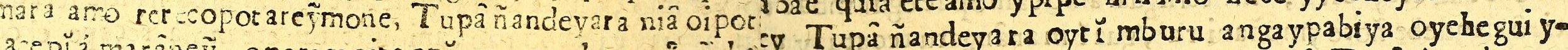
a gLấano. inỹngatu haguame. Ma mbae ac tepacoi Tupa Angeles po.

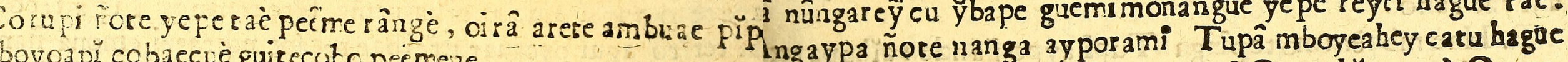
boyoa pi co baecuè guitecuto peemene.

Dodrina IV.

Prosigue la mirma materia, ece aracae. Nda pehechai paco eguí Quarahi reco? QuaraInânga pit irobaichuaramo guecohapee nomaémbotari etey ece, oyehcgui ypeá pucu eteybo berecobo, ayporami etey ânga Tupầ at a pireỹ robaichuaramo hecohafee.

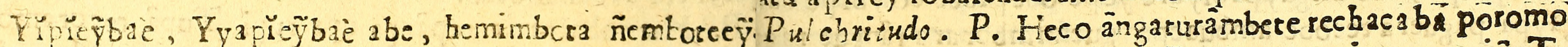

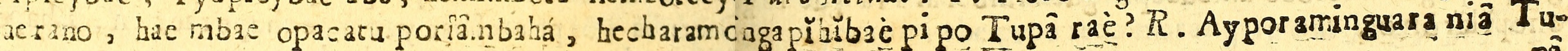

D 
as gravuras estão também no miolo. São vinhetas que foram usadas pela primeira vez em Loreto, no livro De la diferencia entre lo temporal y eterno [...].

Há alguma semelhança entre as letras grandes da folha de rosto deste livro e aquelas da folha de rosto do Arte de la lengua guarani [...]. É o que nos leva a crer a comparação entre os S's. Se comparamos os S's dos três livros de Santa Maria - o Vocabulario, o Arte e o Explicacion -, imediatamente percebemos que os S's do Arte e Explicacion tem o desenho parecido e são muito diferentes dos S's do Vocabulario [FIGURA 144]. Dos cinco S's mais parecidos (três do Explicacion e dois do Arte,) vemos que apenas um tem o desenho um pouquinho mais estreito, ainda assim ele segue o mesmo tratamento da serifa e modulação do traço. Me parece que, com exceção deste $\mathrm{S}$ mais estreito, os demais são os mesmos tipos que foram usados no Arte [FIgura 145].

Nós já havíamos notado este tratamento peculiar das serifas e irregularidade na modulação dos traços no Arte de la lengua guarani [...], e de fato alguns dos caracteres com desenhos muito particulares que vimos apenas naquela folha de rosto se repetem aqui. Além dos $\mathbf{S}$ 's, aqui se repetem os desenhos de $\mathbf{E} \cdot \mathbf{T} \cdot \mathbf{J}$ e, com menos certeza, digo que se repete também o desenho de U [FIGURA 146]. Apesar da incerteza, é notável que se comparamos todas as ocorrências de U's, os do Arte e do Explicacion são muito mais parecidos entre si do que com os outros [FIGURA 147]. O mesmo parece ocorrer em relação ao A, que apesar de ter o mesmo tamanho de A's que apareceram no Vocabulario e no Arte, tem a barra horizontal muito alta, diferente de qualquer outro que vimos antes. No Arte também havia um A diferente dos demais, pelo tratamento do traço e das serifas, além de ter um vértice muito agudo. Estas características podem ser vistas neste $\mathbf{A}$ do Explicacion, mas a diferença na altura da barra é gritante [FIGURA 148]. O que me faz pensar que o que há de comum entre estas letras e aquelas do Arte de la lengua guarani [...], na folha de rosto, são as serifas, que chamei de "singelas", e a irregularidade do traço.

Não há muitas diferenças entres as capitulares deste livro e aquelas do Arte. Estão basicamente em dois tamanhos e com as mesmas diferenças internas. Podemos afirmar isto com tranqüilidade sobre as capitulares $\mathbf{M} \cdot \mathbf{T} \cdot \mathbf{C}$, sempre em dois tamanhos, com desenhos que vimos antes. $\mathrm{O} \mathbf{H}$, que lá era solitário, aparece novamente aqui, entre as capitulares e na folha de rosto. Têm todos o mesmo desenho. [FIGURA 149]

Oss N's que aparecem no miolo são de três tipos: um deles é largo, como os N's capitulares do Manual de Loreto, eles aparecem nos dois livros com e sem til, mas

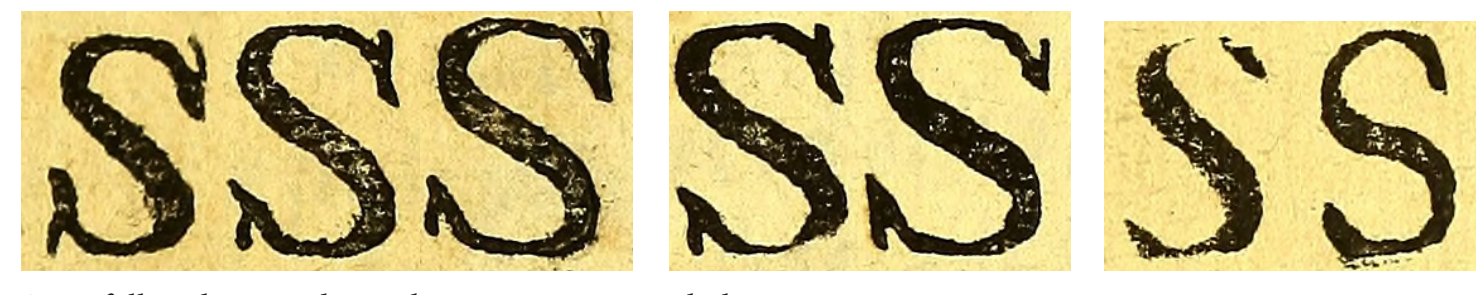

$\mathbf{S}$ nas folhas de rosto do Explicacion, Arte e Vocabulario.

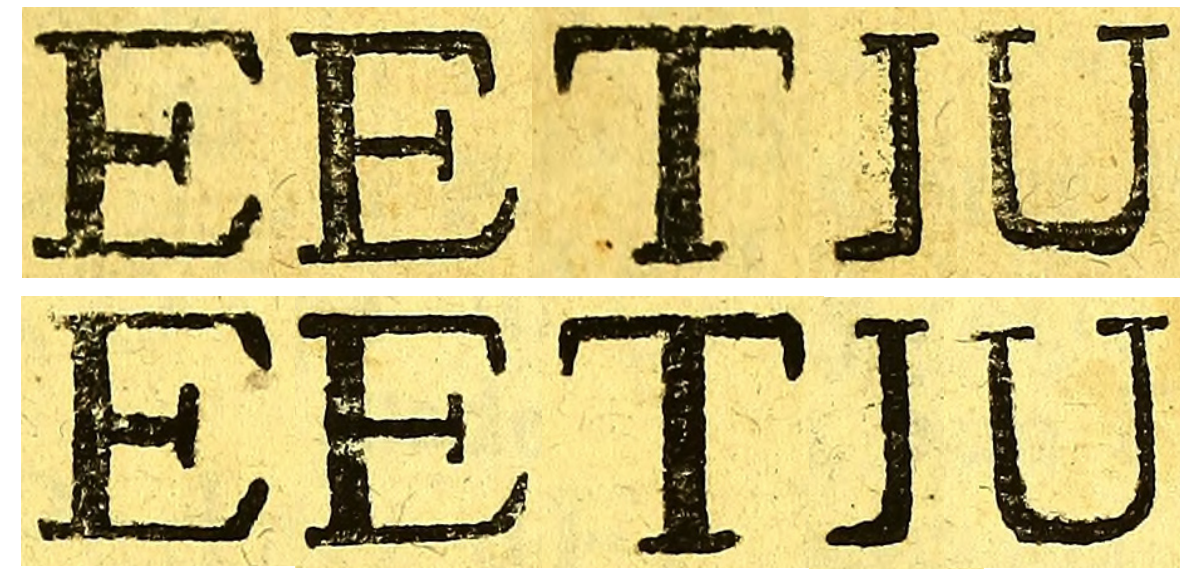

$\mathbf{E} \cdot \mathbf{T} \cdot \mathbf{J} \cdot \mathbf{U}$ nas folhas de rosto.
FIGURAS

$144 / 145$

Explicacion

Arte

Vocabulario

FIGURA 146

Explicacion

Arte
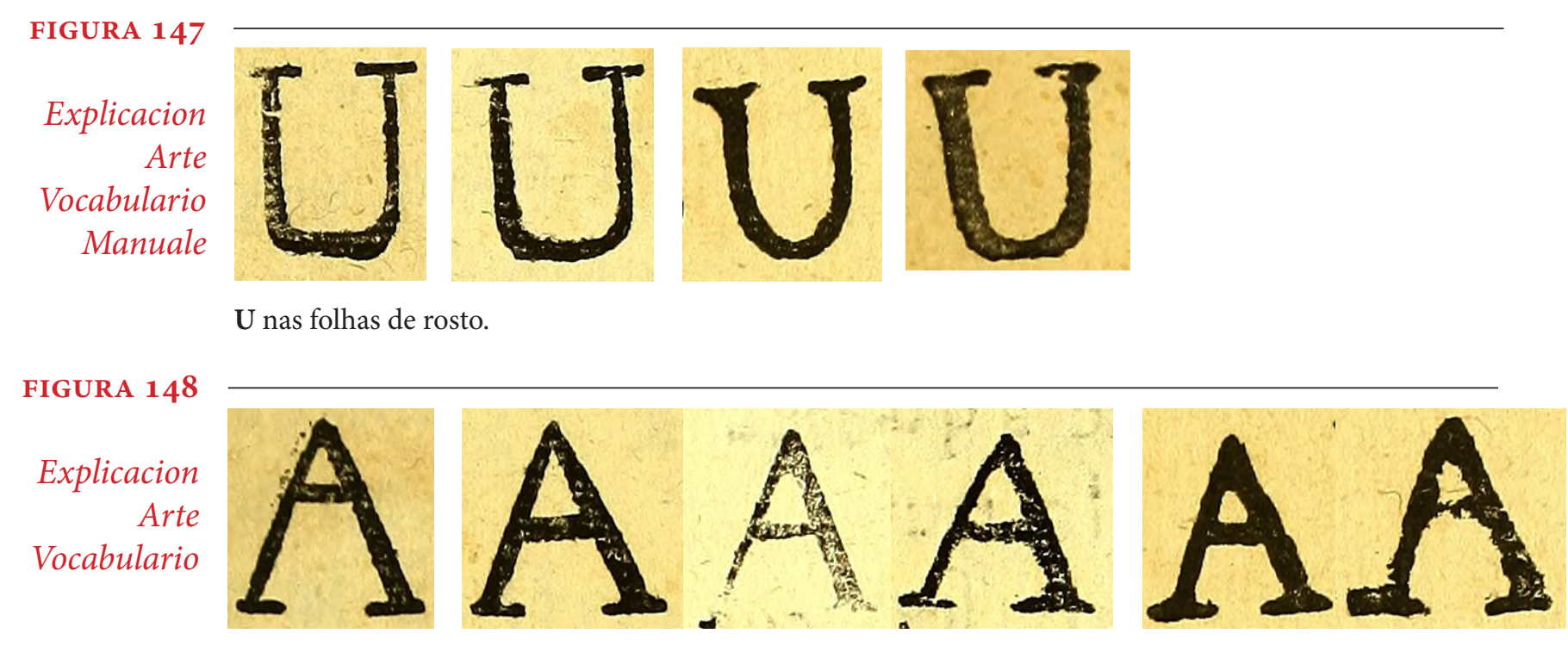

A nas folhas de rosto e miolo

FIGURA 149

Explicacion

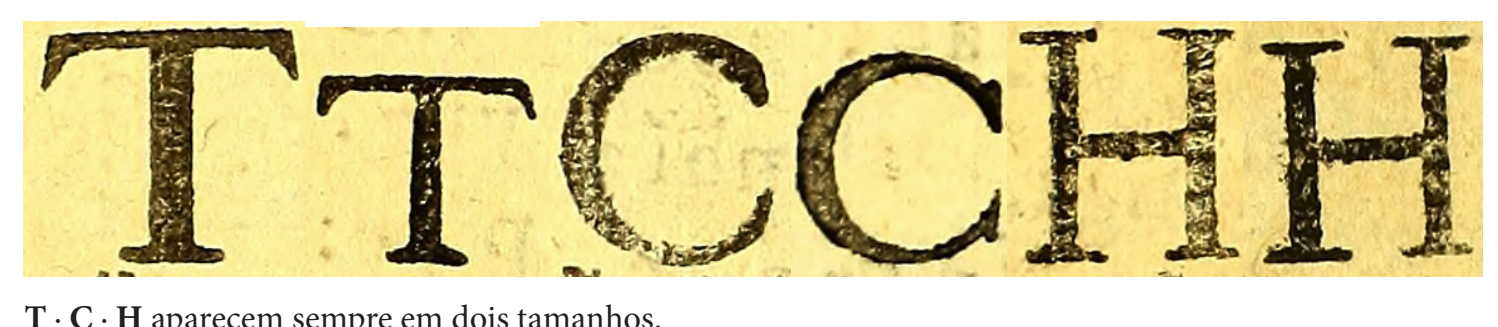


sempre com o mesmo desenho [FIGURA 151]. Além destes, aparecem no Explicacion outros dois N's, sempre com til: um menor e com menor contraste entre os traços grossos e finos (uma modulação homogênea) e outro maior e com muito contrast entre os traços grossos e finos [FIGURA 152]. Esta diferença no contraste entre traços nos chama muita atenção. Até agora havíamos observado diferenças nas serifas, nos tamanhos, nas proporções internas (altura e tamanho das barras por exemplo). Mas este $\mathbf{N}$ nos lembra que há também esta "diferença" possível.

Algumas capitulares que apareciam em grande quantidade no Arte, como E e $\mathrm{L}$, não aparecem em grande quantidade neste livro, o que nos impede de compará-las. Neste livro não aparece nenhum $\mathbf{L}$ capitular, e apenas dois $\mathbf{E}$ 's, cada um com

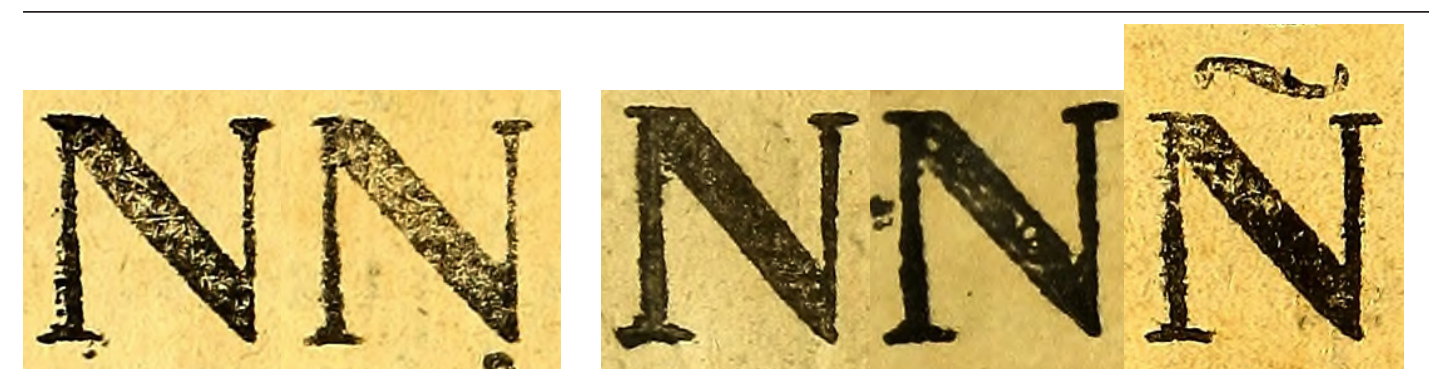

FIGURA 15

$\mathbf{N}$ no miolo do Explicacion. $\mathbf{N}$ e $\tilde{\mathbf{N}}$ no miolo do Manuale.

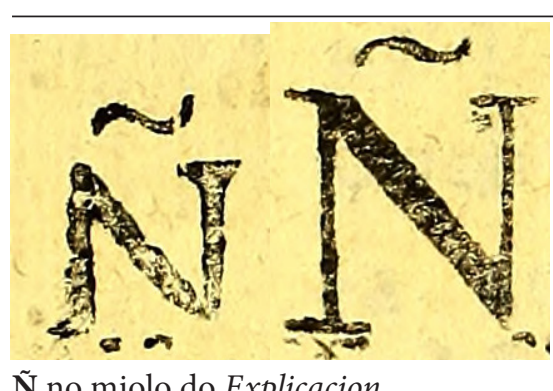

Ñ no miolo do Explicacion.
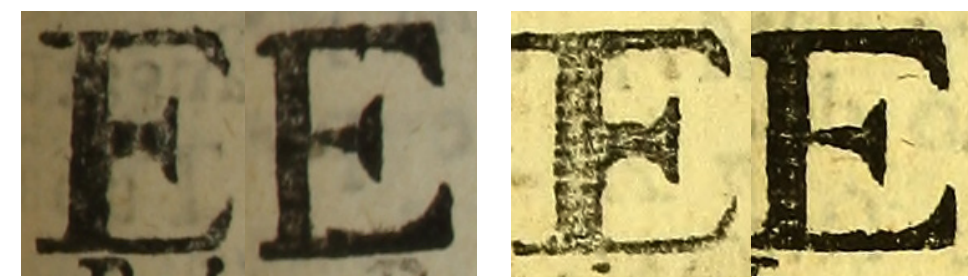

FIGURA 153

Explicacion Arte

E's capitulares no Explicacion e no Arte.

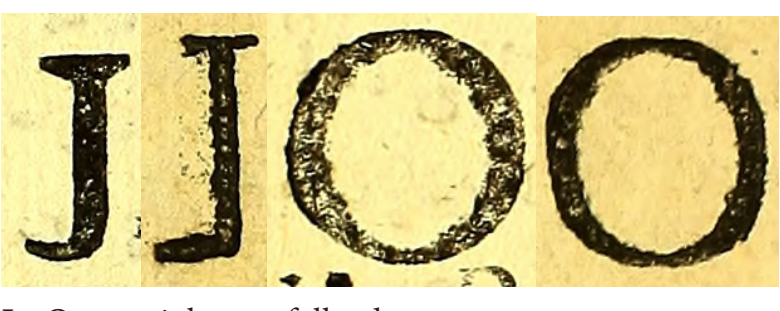

FIGURAS

$154 / 155$

Explicacion um desenho, vistos antes no Arte [FIGURA 153]. Aqui há J's de um novo desenho. As serifas são triangulares, diferentes daqueles com as serifas "singelas" que vimos antes, na folha de rosto [FIGURA 154].

Há dois desenhos para O's, com o mesmo tamanho: um é mais oval, as proporções são alongadas, o outro é mais redondo [FIGURA 155].

Os $\mathbf{P}$ 's aparecem em dois tamanhos quase iguais e com desenhos variados, é difícil afirmar se são ou não os mesmo P's que já vimos no Manual de Loreto [FIGURA 156]. Os I's também aparecem em dois tamanhos quase iguais. Os desenhos são diferentes também, vê-se pelas serifas: os maiores tem serifas retas, os menores têm serifas triangulares. Talvez haja alguma diferença entre os menores, do mesmo tamanho, um parece ter a serifa realmente mais triangular que o outro, e são todos diferentes do I da folha de rosto [FIGURA 157]. É possível afirmar que são I's de, no mínimo, três desenhos diferentes, possivelmente quatro desenhos diferentes.

Há também Y's de dois tamanhos diferentes: os maiores são ora mais largos, ora mais estreitos. Os menores, sempre acentuados, são também ora mais largos ora mais estreitos [FIGURA 158]. O mesmo vale para os A's, que têm desenhos variados, mas que já foram vistos antes, no Manual de Loreto e no Arte [Figura 159].

Algumas vezes os tipos menores, aqueles de $18 \mathrm{pt} \mathrm{e} 14 \mathrm{pt}$ aparecem como capitulares. Há, nesta condição: $\mathbf{O} \cdot \mathbf{N} \cdot \mathbf{M} \cdot \mathbf{T} \cdot \mathbf{S} \cdot \mathbf{H} \cdot \mathbf{E} \cdot \mathbf{A} \cdot \mathbf{U}$ [FiguRA 160].

Fora as capitulares, há, no miolo, outras quatro letras grandes, na página 1 do livro, que escrevem "REZO" [FIGURA 161]. O E e O parecem-se com letras que vimos antes, neste mesmo livro e em outros [FIGURA 162]. O R é muito peculiar, não se parece com nenhum outro $\mathbf{R}$ [FIGURA 163]. Tanto ele quanto o $\mathbf{Z}$, parecem ter aquelas características "pouco homogêneas" e as serifas quadradas "singelas" que vi na folha de rosto deste livro e no Arte de la lengua guarani [...].

Lembro que a folha de rosto tem letras grandes de dois tamanho: enquanto estas letras grandes da página 1 do livro, escrevendo "REZO" têm o tamanho das letras grandes maiores, as capitulares têm o tamanho das letras grandes menores. Lá, na folha de rosto, neste tamanho "grande menor", vemos algumas letras conhecidas do Arte: o N "solitário" de proporções alongadas, que lá era capitular [FIGURA 164]. Um E, que lá estava na folha de rosto [FIGURA 165]. C's e um L que parecem-se se com outros que vimos no Arte [Figura 166]. Os I's, $\mathbf{P}$ 's e $\mathbf{X}$ parecem cair na categoria dos "singelos", com suas serifas de palito [FIGURA 167]

Por mais que seja possível formar novos conjuntos - pelas serifas, pelas proporções, pelos tamanhos - é muito interessante que novas letras não param de aparecer. Ainda que algumas das nossas observações estejam sujeitas a dúvidas, principalmente no que diz respeito aos detalhes mais suscetíveis a mudanças decorrentes de quantidade de tinta usada na impressão, é inegável a grande variedade de desenhos disponíveis nas missões. Não ouso afirmar que nunca tenham sido produzidas 


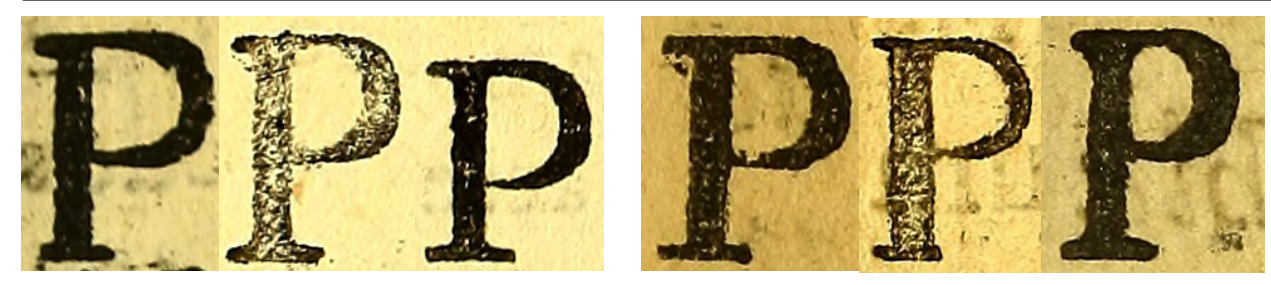

Explicacion

P's no miolo do Explicacion e no miolo do Manuale.

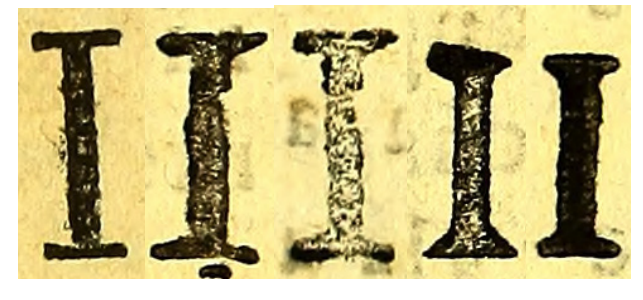

FIGURA 15 Explicacion

I's no miolo. Aparecem em dois tamanhos.

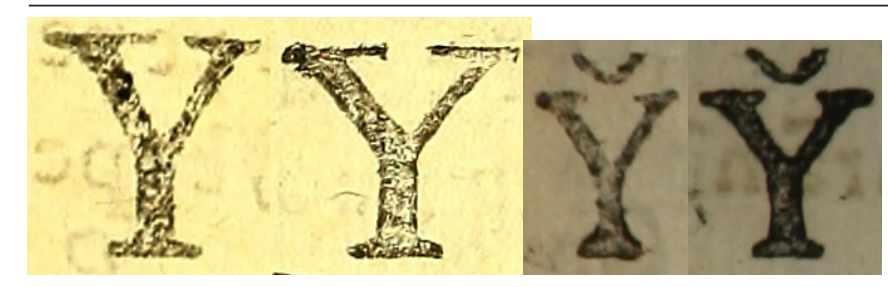

Y no miolo.

AA A A A

FIGURA 158

Explicacion

FIGURA 159

Explicacion

Manuale

Dois desenhos de A que se repetem nos miolos do Explicacion, Arte e Manuale.

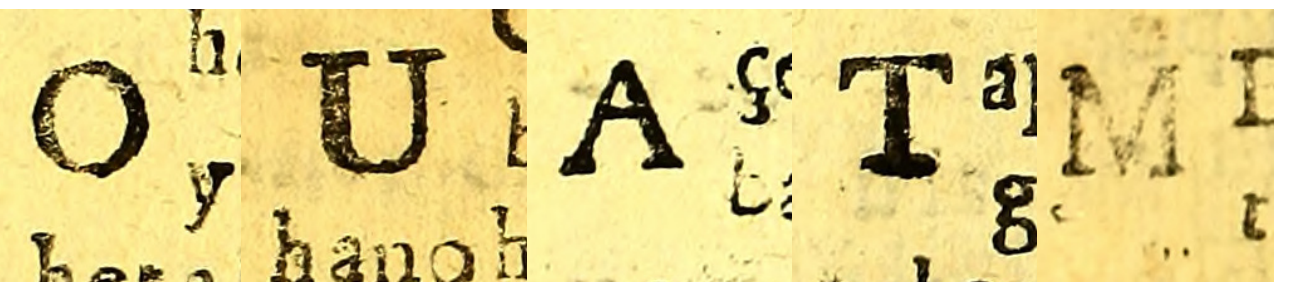

Exemplo de tipos menores na condição de capitulares.

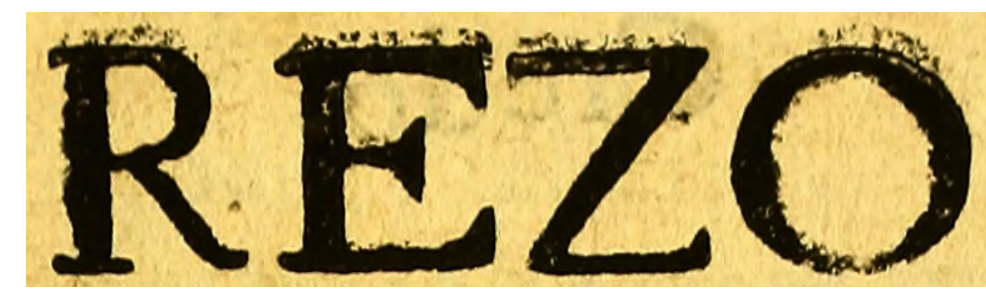

FIGURA 16

Explicacion

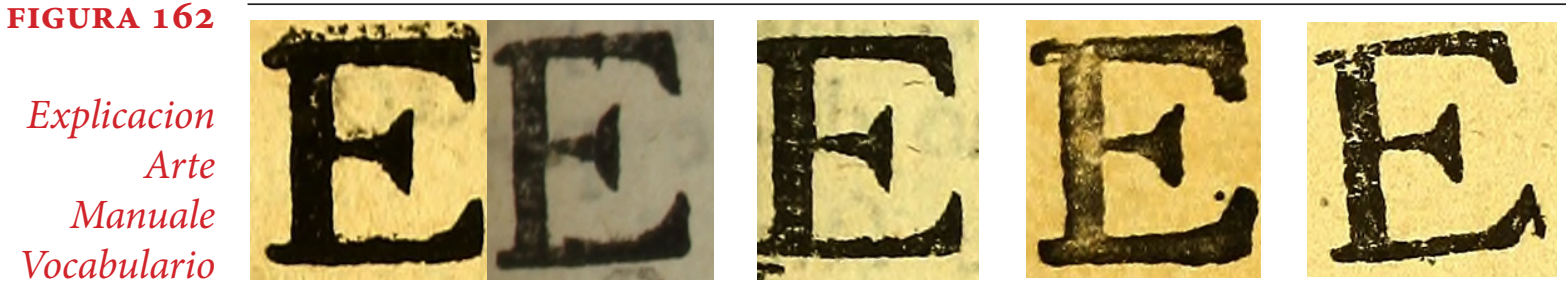

E's no Explicacion, Arte, Manuale e Vocabulario.

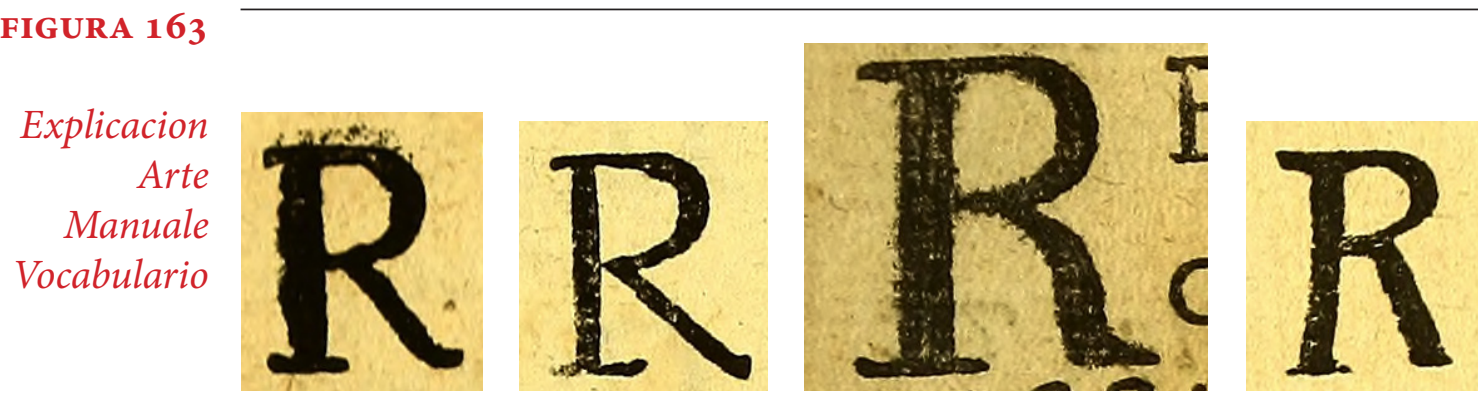

$\mathbf{R}$ com desenhos diferentes.

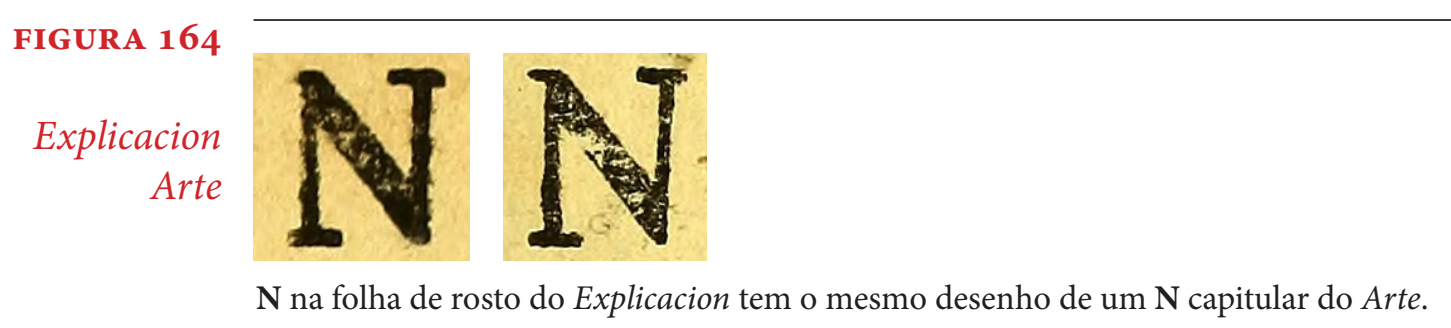

Explicacion
Arte

E na folha de rosto do Explicacion tem o mesmo desenho de um $\mathbf{E}$ da folha de rosto do Arte.

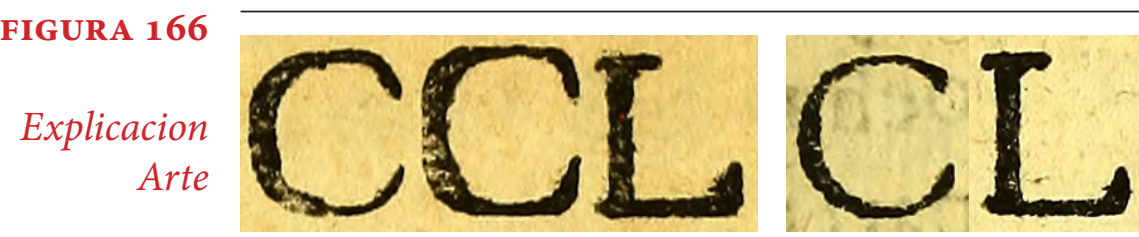

C e L na folha de rosto do Explicacion tem o mesmo desenho de $\mathbf{C}$ e $\mathbf{L}$ no miolo do Arte.

FIGURA 167

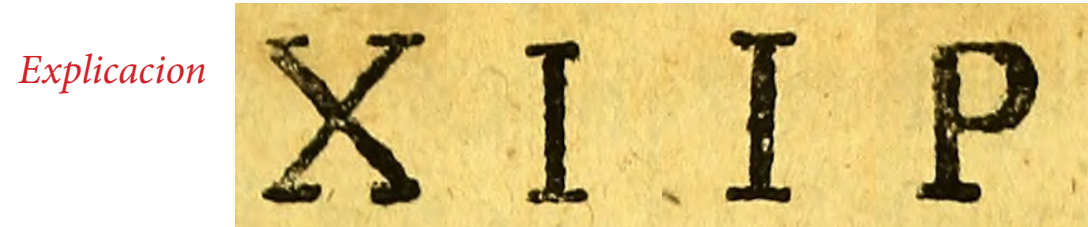

$\mathrm{X}$, I e $\mathbf{P}$ na folha de rosto do Explicacion. 
matrizes e fundidos tipos nas missões guaraníticas rio-platenses, mas quanto mais avançamos nas análises, mais claro fica que a tipografia guaranítica dispunha de uma miscelânea de tipos fundidos em matrizes diferentes. Assim, fica cada vez menos ousado afirmar que, se fundiram alguns tipos lá, outros tantos vieram de fora.

3.1.3 Letras impressas em São Francisco Xavier

SERMONES Y EXEMPLOS EN LENGUA GUARANI Por Nicolas Yapuguay Con direction DE VN RELIGIOSO DE LA COMPAÑIA DE IESUS. En el Pueblo de S. Francisco Xavier Año de MDCCXXVII.

Três anos depois da impressão do Explicacion del catechismo [...] e do Arte de la lengua guarani [...] em Santa Maria, vemos mais um livro em quarto ser impresso, agora na Redução de São Francisco Xavier [FIGURA 168 • pP 120-121] [FIGURA 169 - PP 122-123]. Aqui novamente estão no miolo os tipos de 14pt e 18pt, os alongados e quadrados, compondo a grande massa de texto e marcando as aberturas de seções, respectivamente.

Se de Loreto para Santa Maria tivemos algumas surpresas - desapareceram os caudais maneiristas e as enormes capitulares de Loreto e apareceram tipos irregulares, com serifas "singelas" - de Santa Maria para São Francisco Xavier há menos novidades. A folha de rosto continua com dois tamanhos grandes e dois tamanhos pequenos. As capitulares têm o tamanho das maiores letras da folha de rosto. O que há de novidade é a constância no tamanho das capitulares. Elas são sempre do mesmo tamanho e quase sempre têm o mesmo desenho.

Os A's capitulares, que mudavam muito nos outros livros, tem aqui sempre o mesmo desenho, o mesmo vale para os vários O's C's M's T's e S's. J e I aparecem só uma vez cada um [FIGURA 170]. São desenhos já conhecidos, que vimos nos livros de Santa Maria.

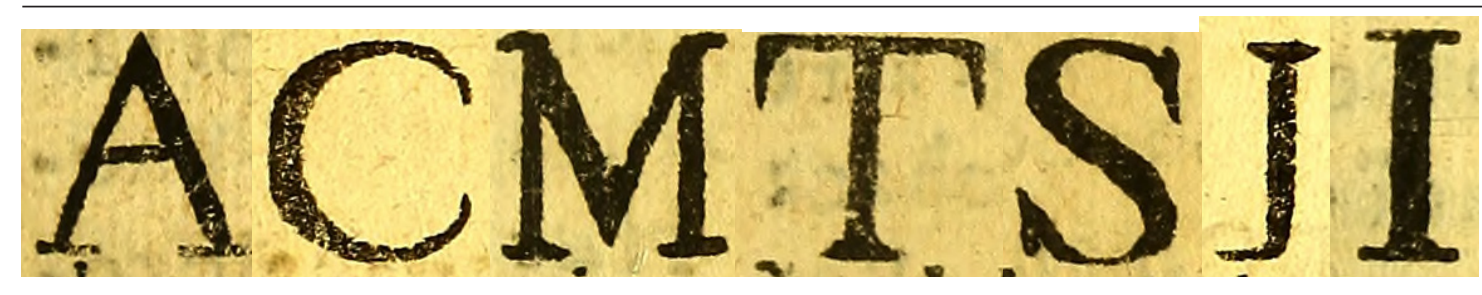

FIGURA 170

Caracteres no miolo do Sermones.
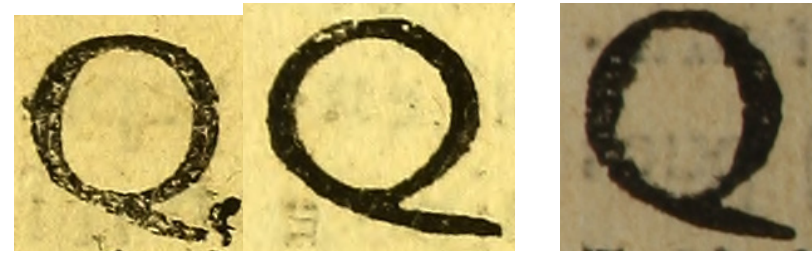

FIGURA 171

Sermones

Arte

Q's no miolo do Sermones, diferentes entre si e diferentes do $\mathbf{Q}$ que vimos no Arte.
Ainda assim, não podiam faltar novos desenhos: Os Q's que aparecem agora são de dois tipos, um tem a cauda mais longa e é um pouco maior que o outro. Os dois são mais achatados que os Q's capitulares que vimos no Arte [FIGURA 171]. O $\mathbf{H}$ também aparece aqui com dois desenhos, um é igual ao que vimos no Arte e no Explicacion, o outro tem proporções mais largas, não tinha aparecido antes [FIGURA 172].

Aparece ainda um $\mathbf{R}$ capitular diferente de tudo que já vimos. E novos $\mathbf{P}$ 's, de dois desenho diferentes, que também não vimos antes [FIGURA 173].

Aparecem novos Y's também. No Explicacion de el catechismo [...] eram de dois tipos, um mais largo um mais estreito, agora um terceiro aparece, com serifas triangulares e novas proporções - a bifurcação do $\mathrm{Y}$ acontece em outra altura da haste [FIGURA 174]. Os Y's acentuados também aparecem aqui, com diferenças nos desenhos entre eles e também diferenças em relação aos que vimos no Explicacion, o que se pode observar com bastante certeza pela diferença na altura do diacrítico, e com menos certeza pela espessura da haste e desenho das serifas [FIGURA 175].

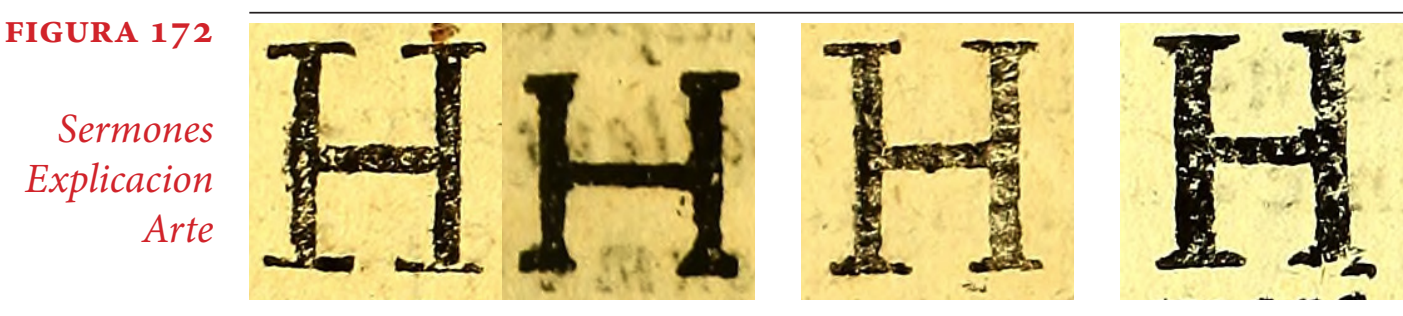

H's no miolo do Sermones, diferentes entre si, mas um deles se repete no Explicacion e no Arte.

FIGURA 173

Sermones

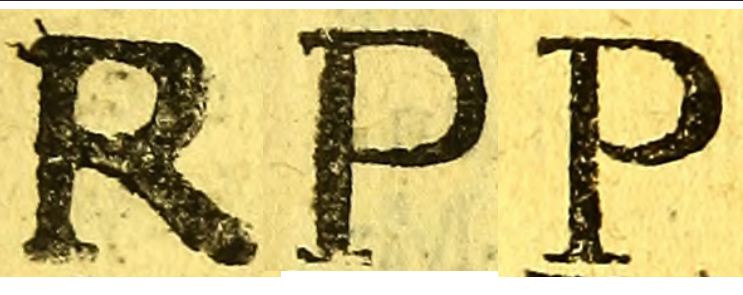

R bastante peculiar no miolo do Sermones. Dois P's, cada um com um desenho, também no miolo.

FIGURA 174

Sermones Explicacion

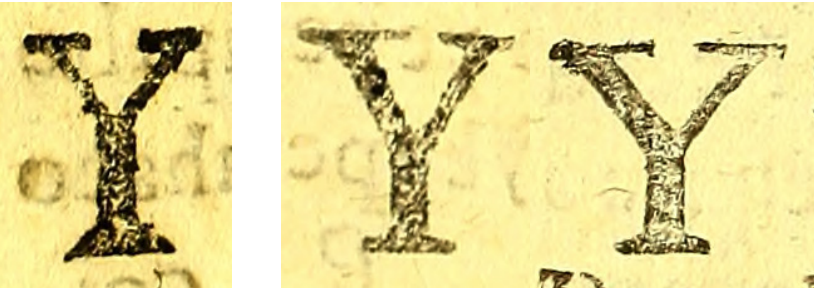

Y no miolo do Sermones, diferente dos dois Y's do Explicacion.

FIGURA 175

Sermones Explicacion

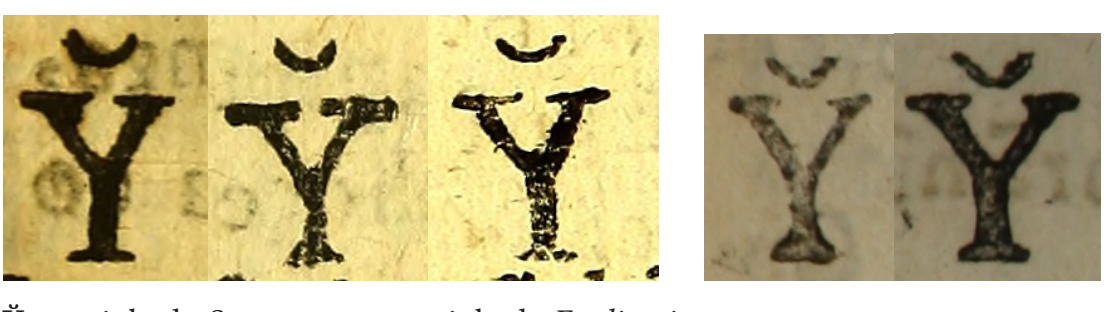

Y̆ no miolo do Sermones, e no miolo do Explicacion. 


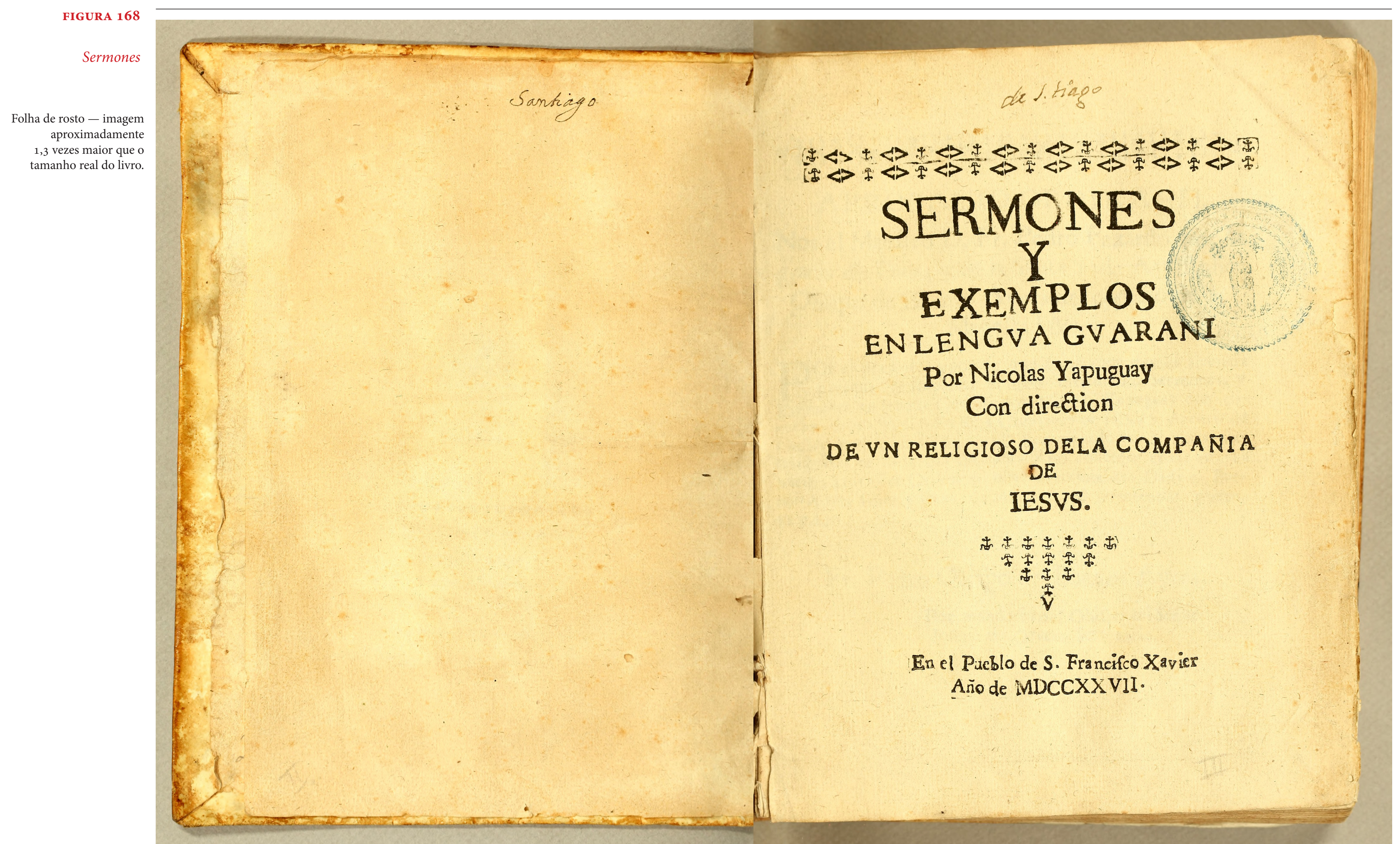


FIGURA 169

Sermones

Páginas do miolo - imagem 1,3 vezes maior que 0 tamanho real do livro. 3o

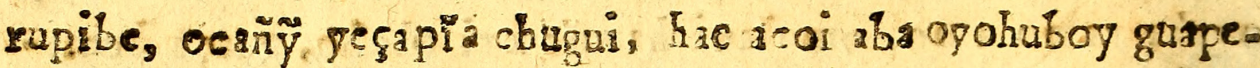
và oholizguàna oiocto ccìre.

Pehendu ima racoeuri peé ne thereminombeucuerra $\mathrm{Ch}$,

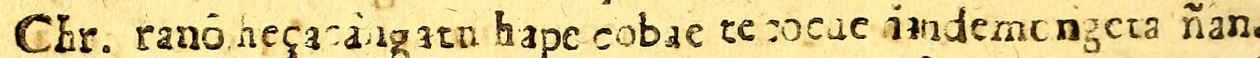

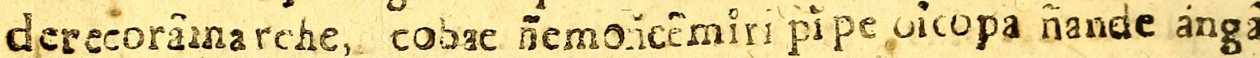
rceǫebchas nanderemimboayeräma rano. Tehenduima ängaipa pipe pusdecuramo pembaeapo marängaur r mo yipes na.

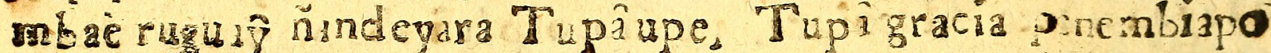
teqiro moasuanduca habangue poreỹ yamboe. nipubar fethé ç̨uraco egufajaga gusecobe yarerci oñemcembiapo caturamo gepe, sieorȩ̂baçuc aberami excy heconi omanörirc mbac mo Tupẩ rexăme omboyecohubuca haguâ amỏ upé obahênge ỹmo. Ma mamegg atu pipo aeci cherniffarendu hagué, cheñemombeú

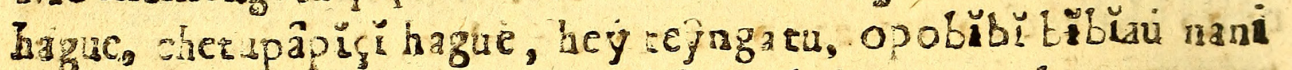
ecey Tupi noembiapocue repira quabeençar a robaque oqua. pa. Giserepannga cherccobc yacrtu cheñencembiafocatu haguzei amo àa yyehubeỹramo -hebe, oyabo, Mbae abaetcera

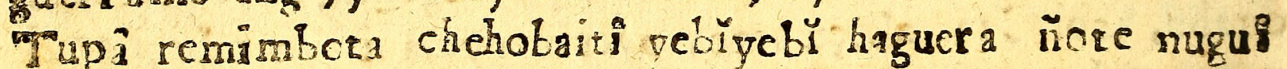
oyehu teconçi tetîró rendape chereití uca habamo, oyabo

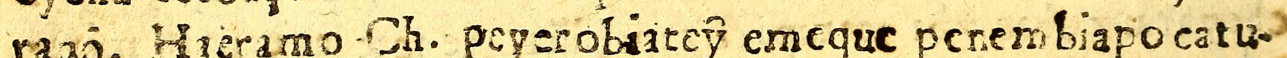
pisi ari qepe àngipiguaçu amo rehe Tpuà gracia maràngátu

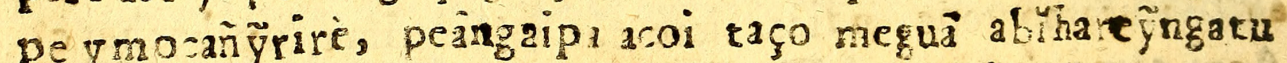
pceancó hazue nomboch há peñembuaçă cata haba fípe range

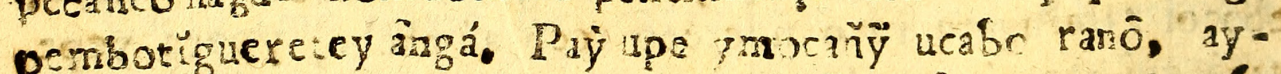
porire eatu teso matang teu rehe peñemoingo peadecobe

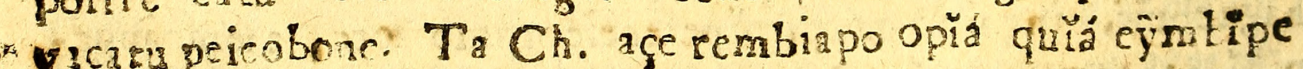

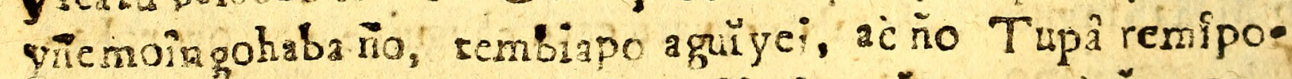
rî̀uercé catu, se ño Tupârembiecla ori catu, de ño fea-

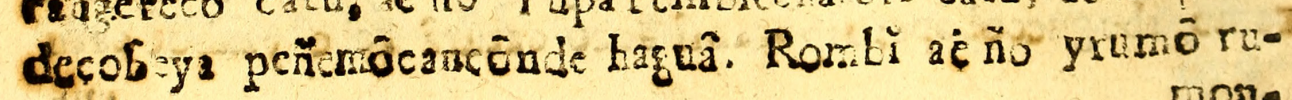

97.

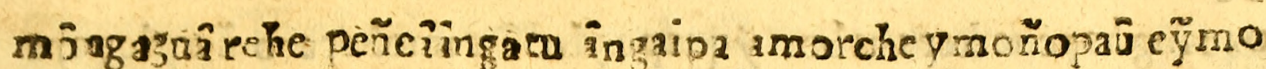
(7) peiolone. Eguirami pendecoramo teming pencecs marangau hague noote en pendecobe pahape perobuhe yepes

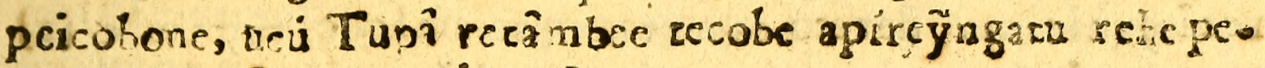
yecoiss aguànari yepiguarâna.

.00

\section{Explicacion.}

1. Cono negocizcion ó comrrato. 2. con ojos, alos nuales nofe oceulea cofa algund. 3. juef na buetros folo enla aparien-

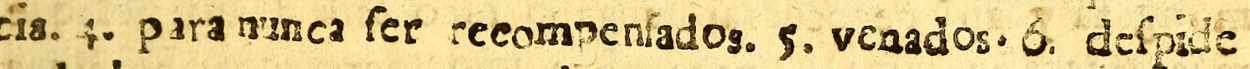
mal olor. 7 . noenereverando.

Para la feria lexta dépues dela III. Dom. de Quarefma.

E Ilaz de ans bienientur da revela el aprecio que feha délazer dela grariade Dios.

Si jeires dorum Lei orc. Joartoq.

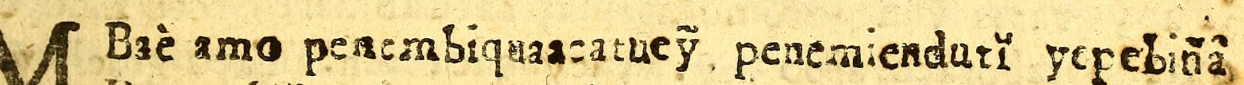
I Pay próbegar, apu curi y aboyequa youpibo puene. dogab̆i aipubae Tupa gracia ecco, ayetamo peë yquazcatubo

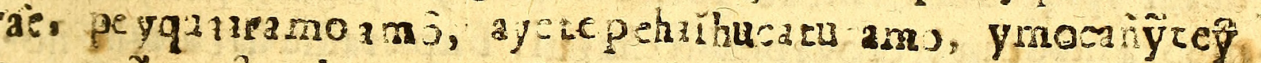

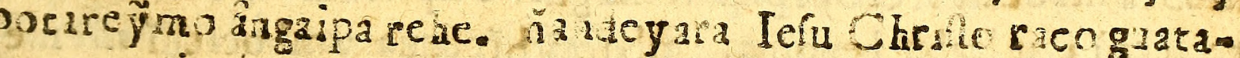
huramo oicobo, Táuçu ano Sa araja ya cerobicape, oguapo

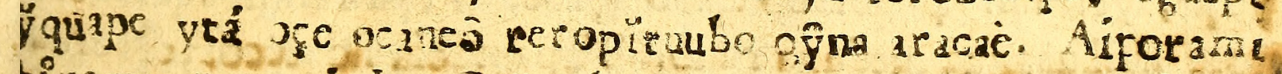

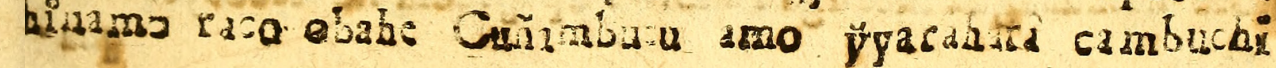




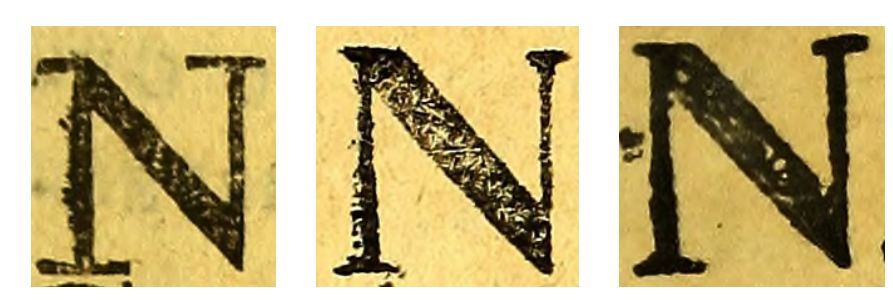

N no miolo do Sermones com serifas mais pronunciadas e diagonal mais finas do que as do $\mathbf{N}$ do Explicacion e do Manuale.

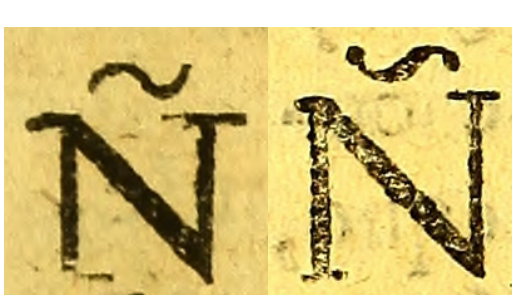

FIGURA 177
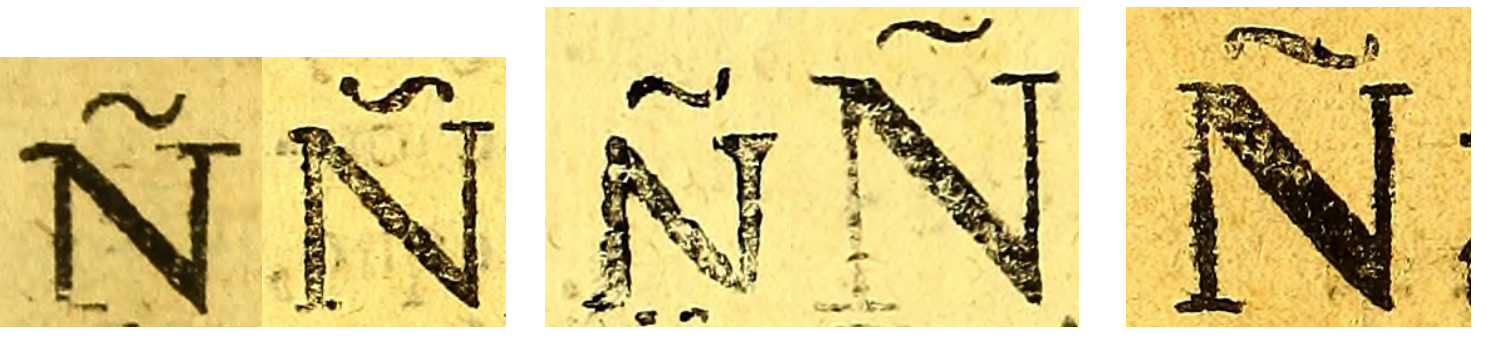

FIGURA 178

Sermones

Explicacion

Manuale

Pelo menos cinco desenhos para Ñ, nos miolos de Sermones, Explicacion e Manuale.

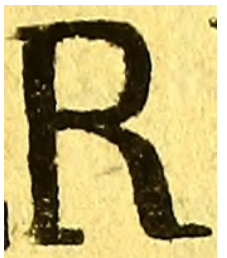

FIGURA 179

Sermones

$\mathbf{R}$ na folha de rosto do Sermones. Um desenho que não foi visto antes.

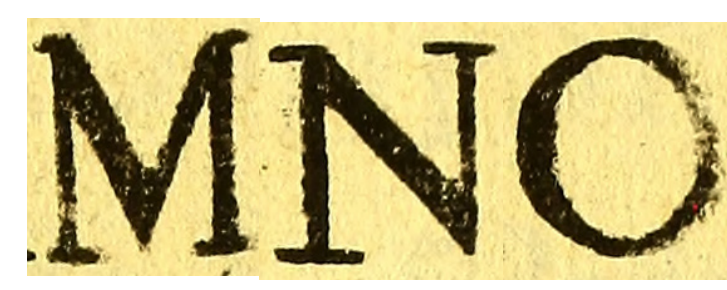

FIGURA 180

Sermones

$\mathbf{M} \cdot \mathbf{N} \cdot \mathbf{O}$ na folha de rosto do Sermones.

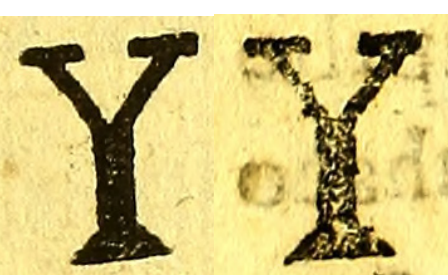

FIGURA 181

Sermones
Os N's aparecem sempre com o mesmo desenho. É um desenho novo, com serifas mais pronunciadas e diagonal mais fina que o $\mathbf{N}$ que vimos no Manual de Loreto e no Explicacion, em Santa Maria [FIGURA 176]. o $\tilde{\mathbf{N}}$ aparece com dois novos desenhos: os dois têm proporções mais quadradas e são um pouco menores do que aqueles que vimos antes, e entre eles há diferença no tamanho das serifas [FIGURA 177]. São pelo menos cinco desenhos para o $\mathbf{N}$ até agora [FIGURA 178].

As letras da folha de rosto também têm suas peculiaridades, a começar pelo $\mathbf{R}$, com um desenho completamente novo [FIGURA 179]. Os demais são menos radicais em suas diferenças: $\mathbf{M} \cdot \mathbf{N} \cdot \mathbf{O}$ têm desenhos já conhecidos [FIGURA 180]. O Y é novidade em relação aos outros livros, mas tem o mesmo desenho do $\mathrm{Y}$ capitular que vimos no miolo [FIGURA 181]. Olhando as serifas, um dos S's parece ser da mesma família daqueles que vimos no Arte e no Explicacion [FIGURA 182]. O outro $S$ é aquele que vimos apenas na folha de rosto do Vocabulario [FIGURA 183]. Há dois E's, um tem o desenho conhecido, foi visto no Explicacion e no Manual de Loreto, o outro, apesar da semelhança nas serifas "singelas" de um E do Arte, tem um tamanho único na barra horizontal [FIGURA 184].

$\mathrm{Na}$ folha de rosto as letras grandes de dois tamanhos: falamos sobre as maiores. As do segundo tamanho são letras já conhecidas, todas foram vistas em capitulares de outros livros.

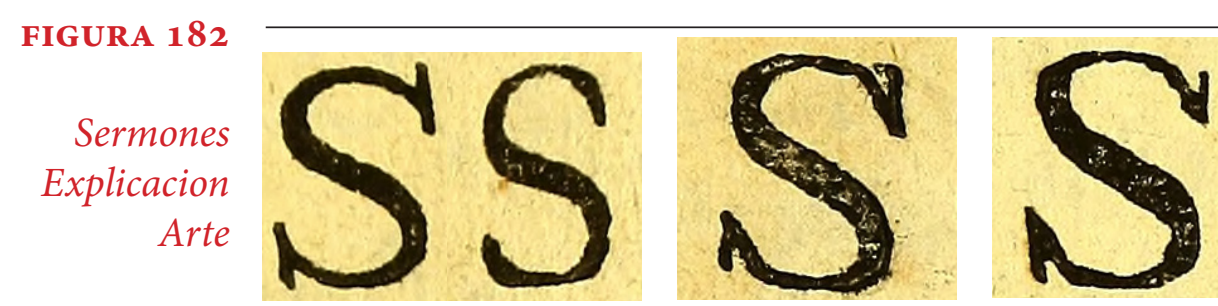

Um dos S's da folha de rosto do Sermones (o mais à esquerda) se parece com os S's da folha de rosto do Explicacio

FIGURA 183

Sermones Vocabulario

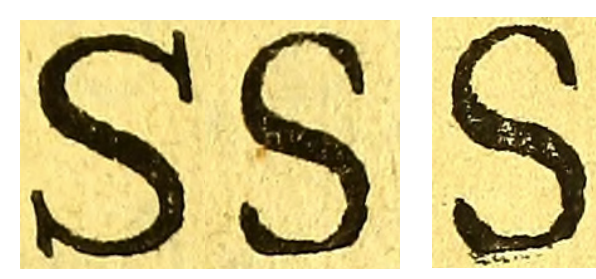

Um dos $\mathbf{S}$ 's da folha de rosto do Sermones (o mais à direita) se parece com o $\mathbf{S}$ da folha de rosto do Vocabulario.

FIGURA 184

Sermones Explicacion
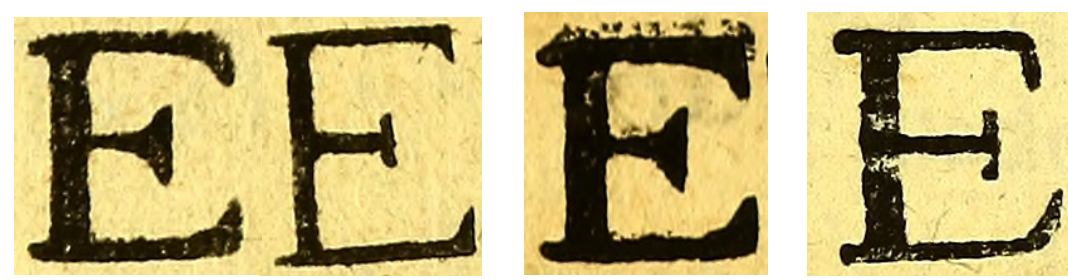

Ha dois Es na folha de rosto do Senmones. O desenho do primeiro é igual a este do Explicacion. O segundo tem serifas singelas, como um $\mathbf{E}$ do Arte, mas sua barra horizontal é mais curta. 
Assim conduzi as análises das letras impressas nas missões, nas Reduções de Loreto Santa Maria la Mayor e São Francisco Xavier.

Compartilhei as dúvidas que encontrei no percurso, as principais têm origem nas seguintes questões: 1) como distinguir, nos desenhos das letras, diferenças decorrem do processo de impressão de diferenças que estão no desenho do tipo? 2) agrupar diferentes caracteres por tamanho é suficiente para afirmar que estes fazem parte da mesma fonte? 3) o que define, afinal, um "conjunto de caracteres" de uma mesma fonte?

Apesar das dúvidas, é inegável a variedade de desenhos de letras em que estão compostos os impressos guaraníticos, o que fez surgir uma hipótese importante, a de que nas Reduções havia tipos vindos de outros lugares.

Considero o primeiro livro, o Instruccion, o mais modesto dos seis que vimos aqui, por não conter letras grandes no miolo, ou itálicas. Ainda assim, já neste livro, notamos a presença de tipos em dois tamanho (14pt e 18pt) provenientes de duas fontes diferentes. Estes tipos se repetiram nos demais miolos, com uso "cruzado" ou não, o que me permitiu verificar que em cada uma das duas fontes havia tipos em dois corpos.

Depois do Instruccion, vimos, ainda em Loreto, as itálicas do Manuale. Ali apareceu a primeira variação de desenho de caracteres do mesmo tamanho: nos $Q^{\prime}$ s. E logo um festival de variedades nas capitulares.

A cada livro acrescentado às análises, as inconstâncias nos desenhos da letras não paravam, principalmente entre as letras grandes. As pequenas (18pt e 14pt) se repetiam e, por isso, não foi necessário descrevê-las em cada um dos livros, a não ser quando notamos, na impressão do Arte em Santa Maria, o acréscimo do U às letras de 18 pt.

O que faço a seguir, no capítulo III, é uma recapitulação das inconstâncias encontradas nos desenhos das letras guaraníticas.

\section{A INCONSTÂNCIA DAS LETRAS RIO-PLATENSES}

A grande variedade de desenho de letras nos impressos rio-platenses, o uso indiscriminado dos variados desenhos de um mesmo caractere, misturados, na composição de cada livro, às vezes na composição de uma mesma palavra, me fez pensar nestas letras e seus usos em termos de "inconstância”" os desenhos são inconstantes, a composição tipográfica é inconstante.

Nas letras manuscritas também vimos "inconstâncias": a pena ora parece obedecer manuais de caligrafia, levantando-se do papel para marcar traços separados e precisos que juntos formam uma letra, ora desenha a letra num só traço, inventando novos percursos para a pena. Isso resulta em inconstância na forma das serifas, nas proporções internas dos caracteres, na espessura dos traços.

O uso da palavra "inconstância” não me veio às ideias por coincidência. Conforme chamei atenção na introdução a esta dissertação (p.25), a "inconstância" é um tema recorrente na literatura sobre as populações ameríndias no período colonial, desde o afamado Sermão do Espírito Santo, em que o padre Antônio Vieira compara a catequização dos índios ao trabalho de esculpir murta - sujeito às inconstâncias em oposição a esculpir mármore - perene, durável -, até o importante ensaio $O$ mármore e a murta - sobre a inconstância da alma selvagem em que o antropólogo Eduardo Viveiros de Castro (2011[2002]) considera a inconstância uma característica fundadora das populações ameríndias. Por isso, dei preferência a esta palavra, em detrimento de outras: as letras poderiam ser chamadas "instáveis", "sortidas", "múltiplas", "variadas", mas escolhi "inconstância" para aproveitar a coincidência. Sem, no entanto, dar ao termo o mesmo relevo que tem na bibliografia sobre a catequização e sem presumir que as letras sejam um "reflexo" da sociedade colonial.

\subsection{INCONSTÂNCIA NAS LETRAS MANUSCRITAS}

A primeira "inconstância" que notei, nos manuscritos, foi aquela na proporção interna dos caracteres. No Edvcacion vimos variar a altura-x (ver figura 19, p.47), no Catecismo vimos variar a altura das ascendentes (ver figura 9, p.42) e no Ordo, menos "inconstante" no desenho das letras, vimos variar a espessura das hastes (ver figura 30, p.55). Além de inconstâncias nas proporções, no Catecismo chamou muita 
atenção a inconstância na forma das serifas, principalmente as serifas de topo (ver figura 13, p.43).

É natural que num manuscrito haja variações, afinal, a mão do escriba não é uma máquina. Por isso, não me prolonguei em notar todas as inconstâncias das letras manuscritas, o que fiz mais cuidadosamente com as impressas, onde diferenças nas proporção de caracteres e formas de serifas são pistas importantes sobre o material de que dispunham os impressores guaraníticos. Ainda assim, há uma inconstância observada nas manuscritas que me parece relevante pontuar, pois diz respeito a maneira como os desenhos das letras eram feitos.

No Edvcacion e no Ordo vimos letras desenhadas com uma pena chata, que dá contraste aos traços grossos e finos e por traços que, juntos, formam a letra. No Catecismo vimos letras desenhadas por um único traço, indicando menos fluência no uso da pena. Assim, vimos, nos três livros, pelo menos duas formas de desenhar o a: uma em que o bojo é desenhado com o mesmo traço da espinha, sendo um "laço" [FIGURA 185] e outro em que o bojo é desenhado com traço separado da espinha [FIGURA 186]. Entretanto, olhando com mais cuidado, vemos mais maneiras de desenhar um caractere, no mesmo livro. No Edvcacion o e é desenhado de pelo menos dois jeitos diferentes, o que se nota pelo local de interrupção do traço [FIGURA 187]. Também no Ordo, muito homogêneo, vemos e's desenhados de duas maneiras diferentes [FIGURA 188].

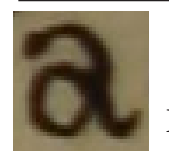

Bojo do a é desenhado separado, como nas minúsculas humanistas.

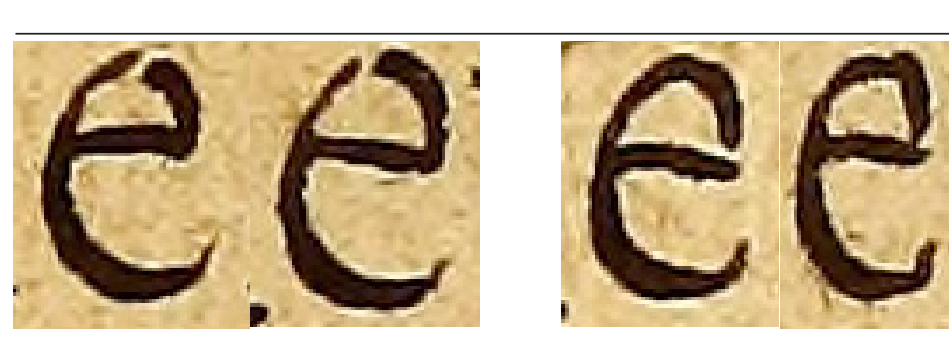

FIGURA 18 Edvcacion

e desenhado de dois jeitos diferentes.

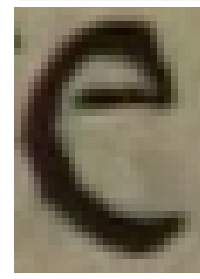

FIGURA 188 Ordo
As análises que apresentei das letras manuscritas não são exaustivas, basta olhar rapidamente os miolos destes livros para sabê-lo [FIGURA 189]. Além disso, não se sabe quantos manuscritos foram produzidos nas Reduções, de forma que mal sabemos a relevância da mostra aqui apresentada. Mas, para além de uma variedade de desenhos de letras, o que estou apontando no pequeno conjunto analisado é uma variedade de maneiras e, quem sabe, técnicas, para desenhar letras. Se são intencionais ou não, se eram aprendidas nos colégios e que manuais seguiam, não sabemos. Mas indicar estas inconstâncias no manejo da pena, ainda que neste pequeno conjunto de letras, atesta a riqueza dos desenhos de letras manuscritas guaraníticas que fica invisível todas as vezes que se repete que são cópias perfeitas.

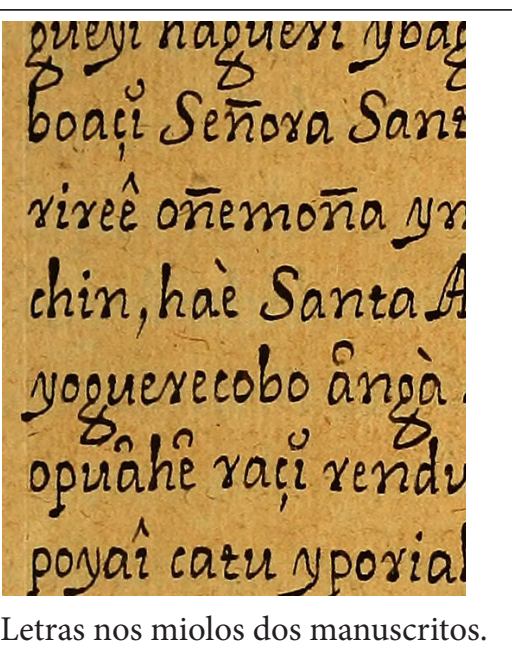
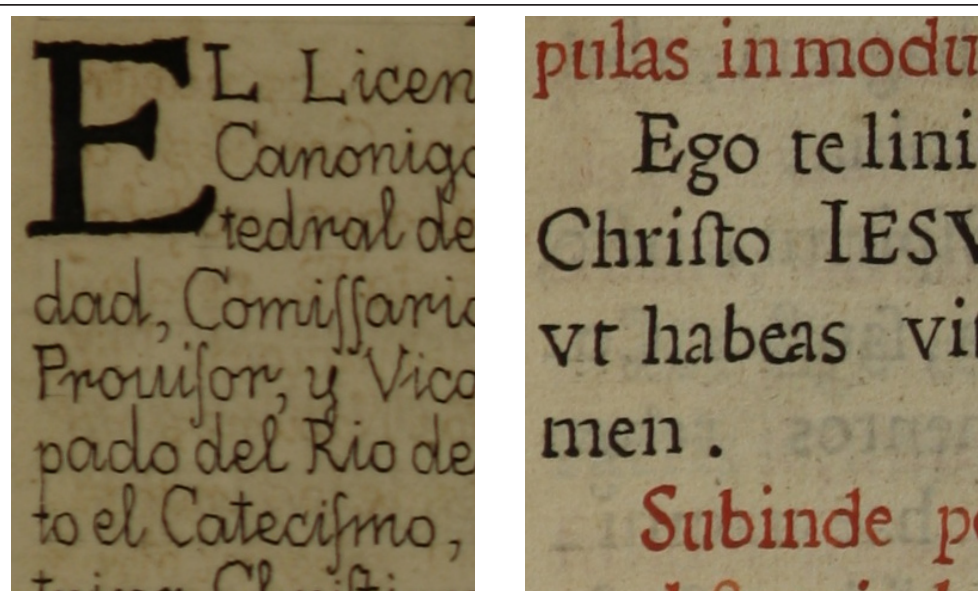

GURA 189

Edvcacion

Catecismo

Ordo

\subsection{INCONSTÂNCIA NAS LETRAS IMPRESSAS}

A primeira inconstância nas letras impressas para a qual eu gostaria de chamar atenção, é a inconstância no desenho das letras grandes, aquelas nas folhas de rosto, em capitulares e em algumas aberturas de capítulo, parte ou seção dos livros que vimos. Me interessa salientar, sobretudo, as inconstâncias em desenhos de caracteres da mesma altura ou de alturas muito parecidas.

As letras grandes que incluí nesta dissertação já são uma seleção das letras grandes que aparecem nos livros. Dentre as selecionadas, temos letras de, no mínimo, sete alturas diferentes, sendo que algumas alturas, as médias, são muito parecidas. Tentei diminuir ao máximo a seleção, para que as "inconstâncias" nos desenhos ganhassem relevância: mantive apenas as letras com altura próxima a altura média ou seja, excluí as menores e as maiores - e mantive apenas as letras com desenhos muito diferentes entre si. Todas as vezes que tive dúvidas sobre as diferenças, optei pela exclusão. Dessa forma, posso ter certeza que na imprenta guaranítica havia as seguintes letras com tamanhos muito parecidos e desenhos diferentes: no mínimo seis desenhos diferentes para A $\cdot \mathbf{E} \cdot \mathbf{P} \cdot \mathbf{S}$, no mínimo cinco desenhos diferentes para $\mathbf{R}$, no mínimo quatro desenhos diferentes para $\mathbf{H} \cdot \mathbf{L} \cdot \mathbf{T}$, no mínimo no mínimo três 
desenhos diferentes para $\mathbf{C} \cdot \mathbf{D} \cdot \mathbf{I} \cdot \mathbf{J} \cdot \mathbf{N} \cdot \mathbf{O} \cdot \mathbf{Q} \cdot \mathbf{U}$ e, no mínimo dois desenhos para M [FIGURA 190 • PP 132-133]. Estes são apenas os desenhos mais diferentes entre si e com diferenças mais marcantes, aqueles que melhor marcam as inconstância nos desenhos das letras impressas. Todas as letras grandes selecionadas para a dissertação, organizadas por ordem alfabéticas, podem ser vistas em anexo (anexo 3).

Mais uma vez fica patente o fato de que letras em sete alturas diferentes não significa que havia, na imprenta guaranítica, sete fontes. Pois há letras com características muito diferentes num mesmo tamanho. Vemos, por exemplo, um $\mathbf{N}$ com muito contraste entre traços grossos e finos no mesmo tamanho de um $\mathbf{R}$ com modulação contínua do traço e quase nenhum contraste [FIGURA 191].

A variedade de desenhos fica ainda mais notável o quanto mais nos apegamos aos detalhes das letras. Se das letras selecionadas - apenas aquelas muito diferentes entre si, e do mesmo tamanho - olhamos para as serifas, por exemplo, as inconstâncias se multiplicam. É o que vemos nas serifas de base [FIGURA 192] e nas serifas

FIGURA 191 • MODULAÇÃO DO TRAÇO

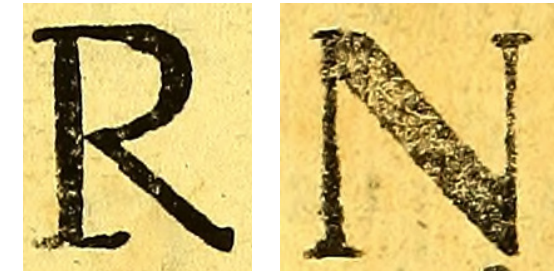

FIGURA 192 · SERIFAS DE BASE

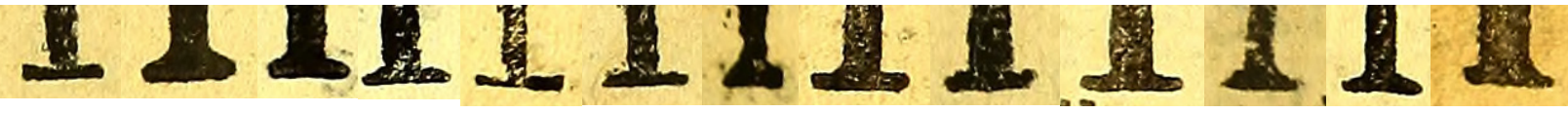

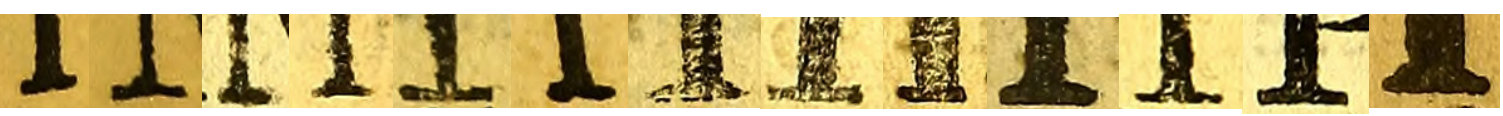

de topo [FIGURA 193].Também os terminais de T e E variam [Figura 194], e do $\mathbf{S}$ [FIGURA 195].

Que haja grupos de letras com características diferentes - o grupo das letra com serifas retas, o grupo das letras com muito contraste entre traços grossos e finos etc. - é normal. Entretanto, chama atenção a "inconstância" também na composição tipográfica. Como notamos sobre os D's capitulares do Manuale, letras com desenhos diferentes são usadas com a mesma função, como se estivessem misturadas na hora da composição. Esta característica dos livros guaraníticos é notável, sobretudo, nas folhas de rosto. Com exceção do Instruccion - onde não há letras grandes - vimos em todas as folhas de rosto a mesma letra com dois desenhos diferentes serem usadas juntas [FIGURA 196], às vezes na mesma palavra. Como se a inconstância fosse uma constante e houvesse uma resistência a adaptar-se ao uso "ordeiro" das letras.
FIGURA 193 - SERIFAS DE TOPO

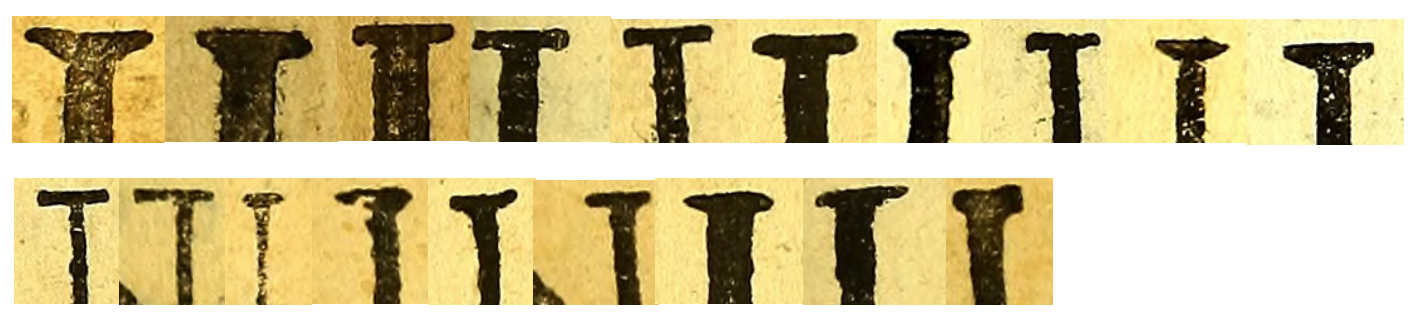

FIGURA $194 \cdot$ TERMINAIS DE T E E

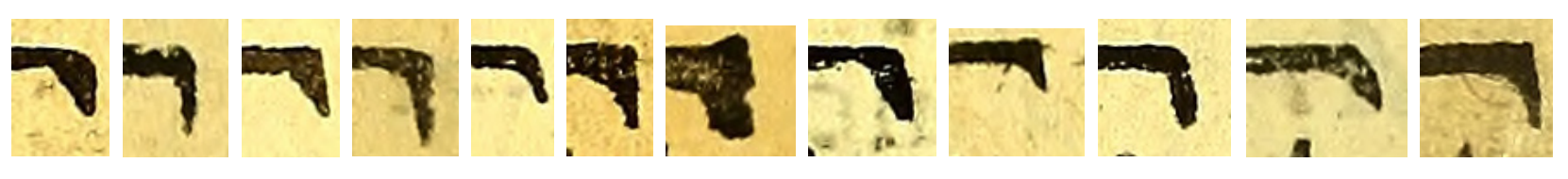

FIGURA 195 - TERMINAIS DO

ขชทับ

FIGURA $196 \cdot$ INCONSTÂNCIA NA COMPOSIÇ̃̃O TIPOGRÁFICA

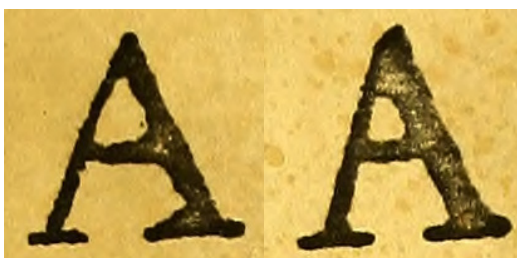

Manuale

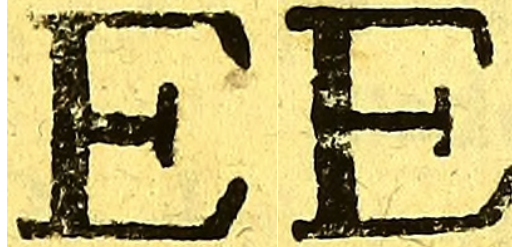

Arte

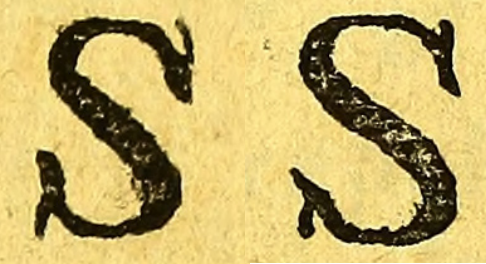

AASS
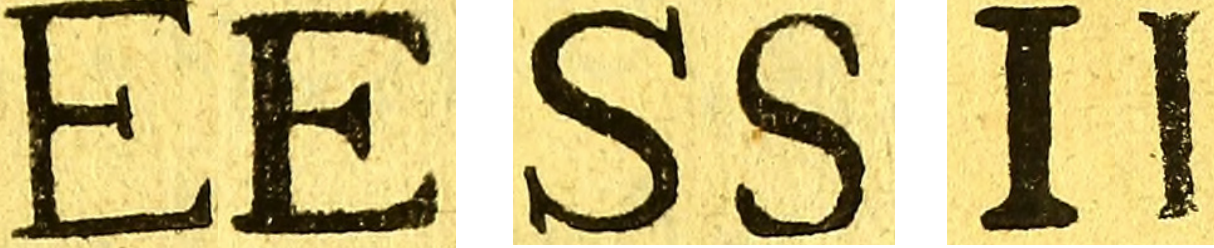
AAAAAA
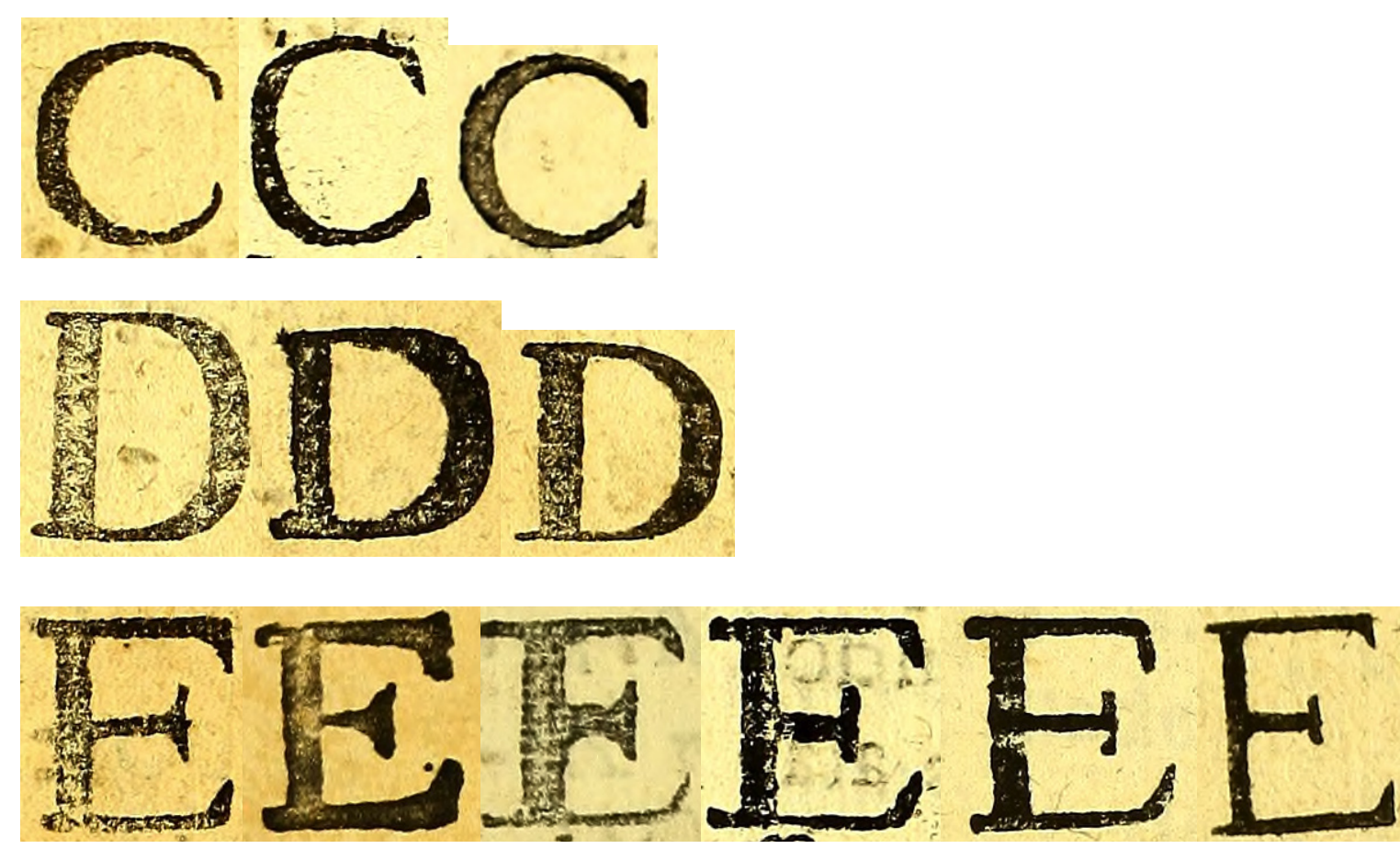

$\mathrm{HHHH}$

III JJJ
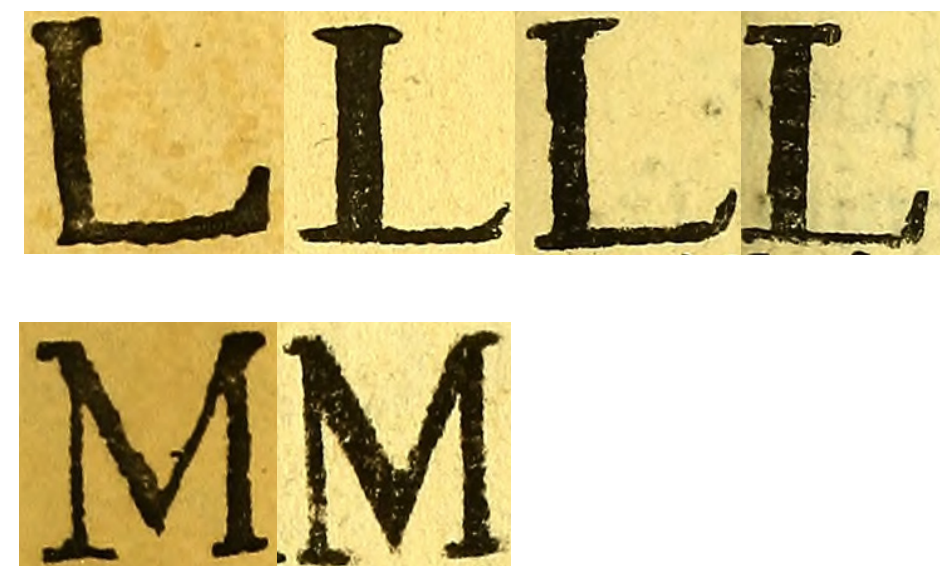

NNN NNNN

PPPPPP

QQQ

RRRRR

SSSSSS

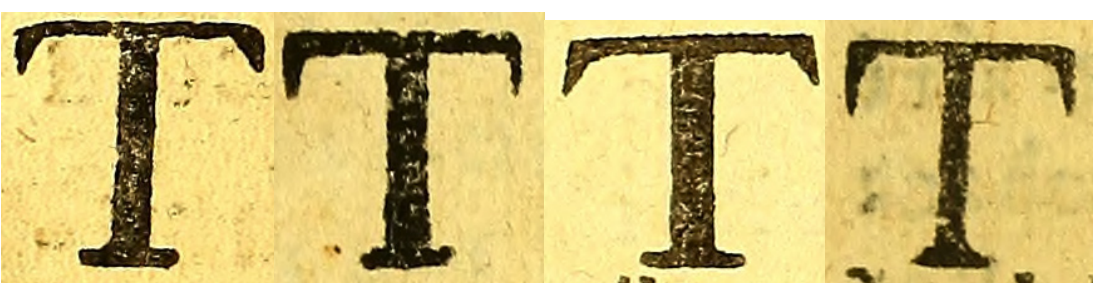

UUU

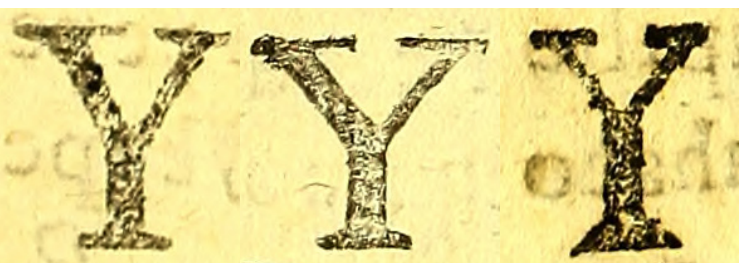


A inconstância no uso das letras torna impossível a tarefa de formar grupos com estas letras, pois, se elas não aparecem juntas, num mesmo livro, pelo menos, como saber se são mesmo tipos de uma mesma fonte? Por exemplo, ainda que tentemos formar "o grupo das letras com muito contraste entre traços grossos e finos", aparecem letras repetidas, com desenhos diferentes no grupo: qual dos dois P's com contraste marcado seria o mais apropriado para estar no grupo do N que também tem contraste marcado? [FIGURA 197] Eu não me arriscaria a responder. Da mesma forma, se olhamos todos os caracteres que têm pouco contraste entre traços grossos e finos, vemos que eles não formam exatamente um conjunto [FIGURA 198] e que há, entre elas, letras que se repetem com desenhos diferentes, apesar dessa característica em comum. Destas letras, algumas chamam muita atenção, por terem traços extremamente finos, e nenhum contraste [FIGURA 199]. Novamente, não há como afirmar, apenas com três caracteres, que estes sejam tipos de uma mesma fonte. Ainda mais por que não aparecem juntos nos livros.

Encontrar desenhos que se repetem em tamanhos francamente diferentes seria uma possibilidade para tentar estabelecer se havia fontes com tipos em mais de um corpo, como estabelecemos para as letras de $14 \mathrm{pt} \mathrm{e} 18 \mathrm{pt}$. Entretanto, as letras do tamanho maior e menor não são tão abundantes, o conjunto de caracteres não é

FIGURA 197 · CARACTERES COM CONTRASTE MARCADO

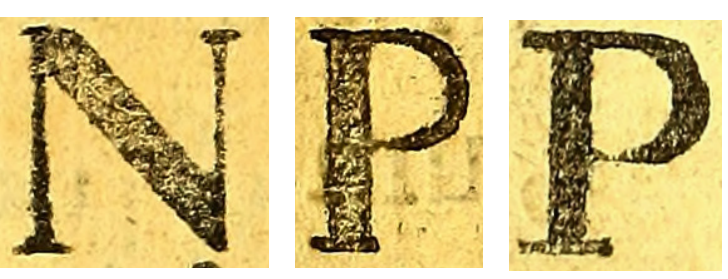

FIGURA 198 - CARACTERES COM POUCO CONTRASTE
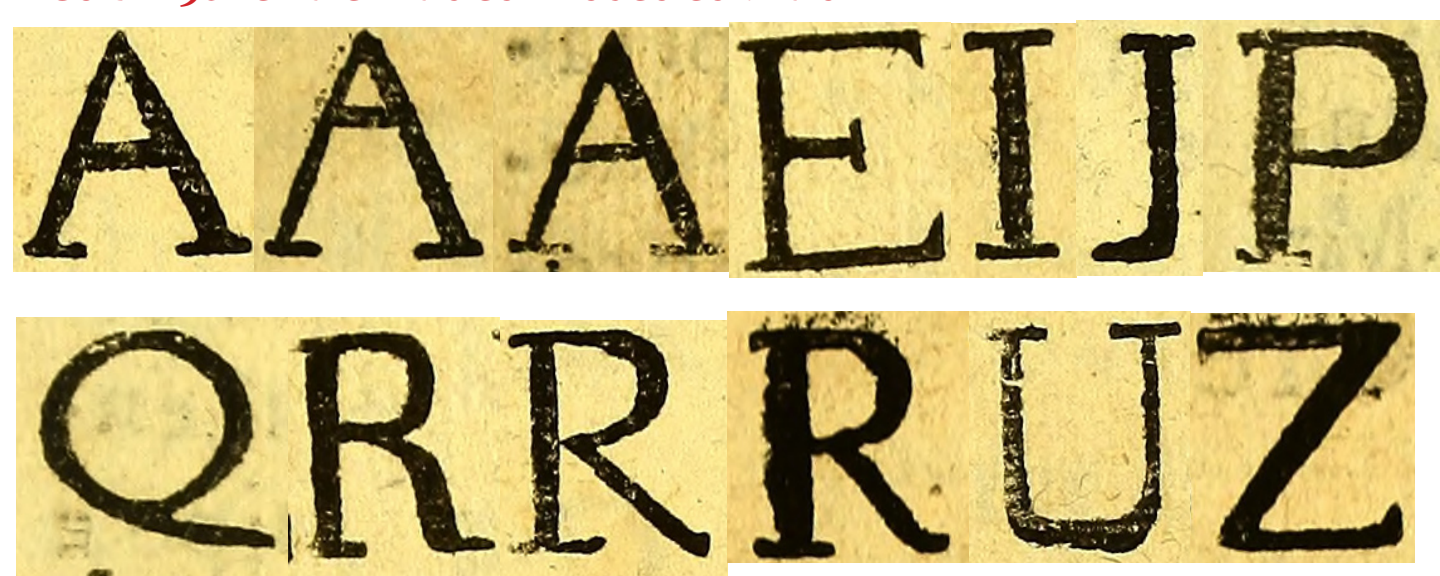

FIGURA $199 \cdot$ CARACTERES COM TRACOS FINOS

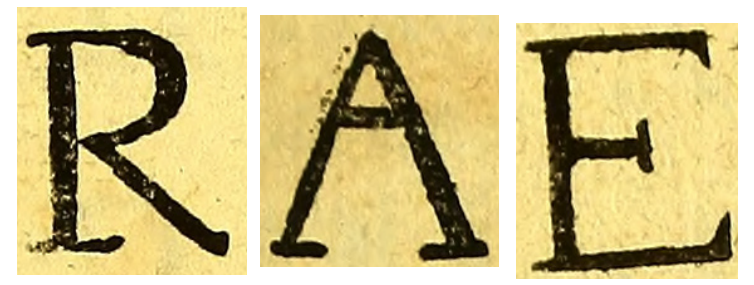

completo entre as menores e não podemos dizer que havia uma "fonte" completa se não vemos desenhos coincidirem em mais de um caractere. Vimos, por exemplo, um $\mathbf{R}$ no tamanho grande que tem o desenho muito parecido com aquele de um $\mathbf{R}$ no tamanho menor [FIGURA 200]. Mas, se esta semelhança não se repete em outros caracteres, não é razoável afirma que estes sejam tipos da mesma fonte.

Por fim, já que estamos olhando as inconstâncias, acho que vale a pena dar a ver um conjunto de letras muito peculiar justamente por suas inconstantes proporções. Trata-se de A $\cdot \mathbf{Y} \cdot \mathbf{P} \cdot \mathbf{Z} \cdot \mathbf{R}$ [FIGURA 201]. O A tem a barra desproporcionalmente alta, o $\mathbf{Y}$ tem serifas desajeitadamente grandes e haste desproporcionalmente grossa, o $\mathbf{P}$ tem o bojo muito largo, o $\mathbf{Z}$ tem a barra superior maior que a barra inferior, o $\mathbf{R}$ também me pareceu "desajeitado" com a serifa de base desproporcionalmente longa. Infelizmente esta característica - proporções peculiares - não faz deste conjunto uma "fonte".

FIGURA $200 \cdot$ DESENHOS PARECIDOS EM TAMANHOS DIFERENTES

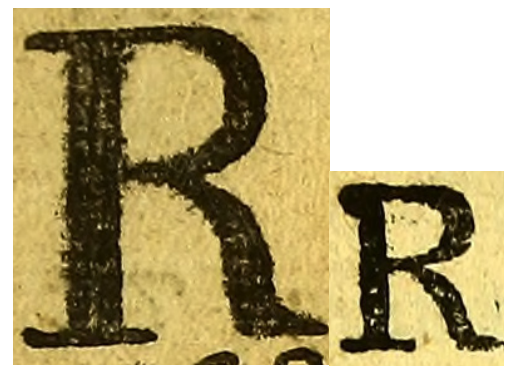

FIGURA 201 · CARACTERES COM PROPORCOOESS PECULIARES

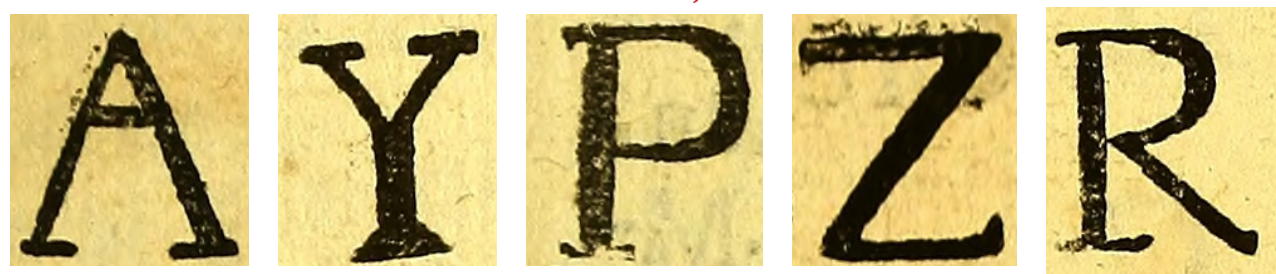

Feito este recorrido pelas inconstantes letras impressas e manuscritas de livros das Reduções Jesuíticas Guaranis, o que sabemos a respeito da imprenta guaranítica frequente exaltada nos relatos de jesuitas por empregar tipos fundidos nas missões $-e$ a respeito dos manuscritos guaraníticos - frequentemente aclamados como prova da habilidade dos guaranis para copiar com perfeição?

Dos manuscritos guaraníticos, sabemos que eram diversas as caligrafias neles empregadas e que a exaltação da destreza guarani para copiar as "belas letras de molde" em nada contribui para reconhecer as práticas caligráficas rio-platenses. Aqui vimos pelo menos duas maneiras diferentes para desenhar uma mesma letra, num procedimento que se repetiu várias vezes, o que, talvez, aponte para técnicas caligráficas próprias. 
Dos impressos guaraníticos, temos resultados mais objetivos e algum avanço na compreensão dos materiais tipográficos de que dispunha a imprenta guaranítica:

- Uma fonte com conjuntos completos de caracteres romanos, no corpos $14 \mathrm{pt} \mathrm{e}$ $18 \mathrm{pt}$

- Outra fonte com conjuntos completos de caracteres romanos, no corpos $14 \mathrm{pt} \mathrm{e}$ $18 \mathrm{pt}$

- Um conjunto de caracteres romanos, apenas letras maiúsculas, usado para marcação tipográfica das páginas;

- Um conjunto completo de caracteres itálicos, no corpo $14 \mathrm{pt}$;

- Um conjunto completo de caracteres itálicos, no corpo 18pt;

- Letras grandes de, pelo menos, 7 tamanhos diferentes.

Além disso, as análises realizadas trouxeram conjecturas importantes sobre a maneira como os livros eram compostos: provavelmente os tipos grandes estavam misturados à mão do compositor, sem distinção exata entre os sete tamanhos disponíveis; freqüentemente os tipos utilizados em uma Redução reaparecem em outras, mas há também tipos que aparecem apenas uma vez (pelo menos entre os livros analisados); e, por fim, me parece que pelo menos uma parte do material tipográfico pode não ter sido confeccionado nas missões - provavelmente as matrizes e mesmo alguns tipos viriam de fora.

\section{CONSIDERAÇÕES FINAIS}

Nesta dissertação estive atenta aos desenhos de letras impressas e manuscritas em livros das Reduções Jesuíticas Guarani, tentando sempre me desvencilhar da documentação textual sobre esta produção livreira. Esta escolha metodológica me permitiu realizar apontamentos sobre o material tipográfico de que se dispunha para imprimir livros na Reduções e sobre o peculiar manejo da pena que transparece em algumas letras manuscritas. Há, entretanto, outros desdobramentos possíveis a partir das análises realizadas.

Os estudos sobre os manuscritos guaraníticos carecem ainda de profundidade. O caminho que me parece mais óbvio a partir do que iniciei é, com auxílio de documentação textual, estudar as formas de ensino e produção da escrita nas Reduções; estabelecer se, e quais, manuais de caligrafia circularam entre os jesuítas no Prata; formar um quadro das diversas caligrafias encontradas em manuscritos guaraníticos; e - por meio de experimentos práticos - reproduzir o tipo de traço e ferramentas utilizadas em cada um dos manuscritos. Talvez assim seja possível estabelecer quais técnicas caligráficas eram utilizadas nas missões rio-platenses, como os manuscritos eram produzidos e se ali se desenvolveram técnicas próprias.

Um pouco mais distante do que me propus a fazer, mas ainda assim no escopo das letras manuscritas guaraníticas, seria de grande valia olhar outras formas de escrita - que não as "letra de molde" encontradas em livros. Dentre as formas textuais manuscritas das Reduções, Neumann identifica: bilhetes, cartas, memoriais, diários, relatos pessoais, atas de cabildo e narrativas históricas (NEUMANN, 2005:113). Valeria a pena estudar a relação entre estas formas textuais e as caligrafias adotadas na sua escrita. Pesquisas como estas seriam uma contribuição para os estudos das práticas letradas nas Reduções, em particular, e da cultura escrita no Novo Mundo, como um todo.

E poderíamos ir ainda mais longe nos desdobramento da pesquisa. Além das manuscritas e impressas, há outras letras rio-platenses a serem consideradas: letras esculpidas em imagens de santos; letras em pinturas; letras em lápides, cruzes, placas e sinos. Talvez as características formais destas letras possam ser reveladoras da cultura visual Jesuítica Guarani. 
Dos impressos guaraníticos, o passo seguinte mais evidente ao que iniciei, é tentar identificar a possível procedência dos tipos utilizados nas Reduções. Comparálos cuidadosamente com tipos utilizados em Lima, no México, em Roma, Madrid e alhures em oficinas tipográficas administradas por Jesuítas. Se for possível conhecer a relação entre os desenhos destas letras e os desenhos de letras impressas em outro lugares, poderíamos estabelecer quais tipos são específicos das Reduções e como foram confeccionados. Ainda no esforço de conhecer o material tipográfico utilizado nas Reduções, seria desejável incluir em futuras pesquisas uma análise da composição tipográfica dos livros. Isso nos traria ideias sobre os chamados "materiais brancos", utilizados nas margens, entrelinhas e outros espaçamentos.

Investigações desse tipos contribuiriam para a compreensão do funcionamento das oficinas tipográficas nas Reduções, ampliando, no quadro maior, o conhecimen to da história da cultura impressa rio-platense, em particular, e latino-american em geral. Acredito que, com o que apresentei nesta dissertação, fiz também uma contribuição neste sentido.

A história da tipografia e da imprensa no Brasil parece muitas vezes aficionada pelo ano de 1808, quando do início do funcionamento da Imprensa Régia no Rio de Janeiro, e aficionada pelos limites territoriais brasileiros, apontando a oficina de Isidoro da Fonseca como a primeira que imprimiu no Brasil. Ignora assim a circulação - e às vezes produção - de impressos em territórios que hoje não fazem parte do Brasil. Este tipo de observação já foi feita antes. Pimenta aponta que,

Tradicionalmente, a definição de quais impressos, oficinas, editores e redatores devem figurar nessa história [da imprensa], na condição de precursores de uma imprensa brasileira antes mesmo da existência política de um Brasil ou de uma nacionalidade brasileira, costuma obedecer ao aparentemente indiscutível critério dos locais de criação ou atuação desses elementos: tudo o que tenha sido produzido no território daquilo que, no cerne de um errático processo desenrolado ao longo das primeiras décadas do século XIX, veio a constituir o Estado nacional brasileiro mereceria, assim, tal atribuição.

(PIMENTA, 2006:19)

Acredito que considerar as redes de circulação e produção de impressos - como aquela dos jesuítas no período colonial - é valioso para a compreensão de uma história da tipografia e da impressa que vá além de dar a saber quem imprimiu primeiro e onde.
Da mesma forma, me parece equivocado divorciar dessa história a produção e circulação manuscrita, já que, no Novo Mundo, imprensa e escrita são novidades contemporâneas. Assim, o que me parece notável nos desdobramentos possíveis desta dissertação é a possibilidade de seguir mantendo em perspectiva o desenho de letras produzidas manualmente, tanto quanto aquelas produzidas mecanicamente, como partícipes da formação de uma cultura impressa.

$$
\sim
$$

As inconstâncias nas letras rio-platenses que apontei no último capítulo, são inconstâncias segundo o critério "desenho". Mas, segundo outros critérios, poderíamos achar semelhanças. Por exemplo, segundo o critério "processo de impressão" ou "composição tipográficas" as letras são semelhantes pois têm a mesma textura, decorrente da tinta e do papel em que estão impressas; têm o mesmo tamanho; e estão assentadas numa mesma linha de base. O que quero notar é que, apesar das diferenças nos desenhos, estas letras formam um conjunto, pelo simples fato de estarem juntas nos impressos guaraníticos: formam o conjunto das letras em livros das Reduções Jesuíticas Guarani.

Neste ponto, faço lembrar o que se diz sobre o barroco, já que as artes produzidas nas missões têm sido consideradas exemplo do que Josefina Pla (PLA, 1975) chamou de barroco hispanoguaraní:

Se uma das características principais do Barroco é a absorção do indivíduo no conjunto, que "deseja precipitar-se nos abismos do infinito" podemos pensar que um traço essencial do barroco - concebido a partir do Barroco histórico - é o desenvolvimento de um impulso unificador, onde as formas individuais são necessariamente convocadas em sua multiplicidade apenas para testemunhar seu pertencimento e sujeição a uma ordem totalizadora.

(MÉNDEZ, 2006:148 - tradução minha ${ }^{47}$ )

Podemos dizer que nos impressos guaraníticos, as inconstante letras estão unificadas segundo uma ordem totalizadora, a composição tipográfica: juntas compõe o livro. Seria esta uma manifestação do barroco na produção livreira rio-platense? Se fossemos analisar as letras segundo uma abordagem classificatória do desenho de tipos, não chegaríamos a classificá-las como "barrocas". Ao contrário, vimos várias letras que lembram as "renascentistas": capitulares com proporções quadradas

47 "Si uno de los rasgos principales del Barroco es la absorción del individuo en el conjunto, que "desea precipitarse en los abismos de lo infinito" podemos pensar que un rasgo esencial de lo barroco - concebido a partir del Barroco histórico-es el despliegue de un impulso unificador, donde (MÉNDEZ, 2006:148) 
e eixo de contraste vertical; minúsculas romanas e itálicas com generosas contraformas; aberturas grandes e claras. Mas não foi a identificação ou classificação dos tipos que conduziu a nossa análise e, por isso mesmo, podemos ver o barroco nas letras guaraníticas. É pela força da relação entre elas e pelo o simples fato de, tão inconstantes, estarem "barrocamente" juntas.

\section{FONTES PRIMÁRIAS}

\section{IMPRESSOS}

MONTOYA, Antonio Ruiz de. 1639. Tesoro de la lengua guarani [...]. Madrid: Iuan Sanchez.

RESTIVO, Paulo. 1724. Arte de la lengua guarani [...]. Santa Maria La Mayor.

YAPUGUAI, Nicolas. 1724. Explicacion de el catechismo en lengua guarani [...]. Santa Maria la Mayor.

\section{IMPRESSOS — FACSIMILES DIGITAIS}

ANÔNIMO. 1721. Manuale ad usum patrum [...]. Loreto. 1721. Facsimile digital: <https:// archive.org/details/manualeadusumpat00cath>

ARENAS, Pedro de. 1728. Vocabulario manual de las lenguas castellana, y mexicana [...]. Mexico: Francisco de Rivera Calderon. Facsimile digital: <http://www.archive.org/details/ vocabulariomanua02aren>

AVILA, Francisco de. 1717. Arte de la lengua mexicana, y breves platicas de los mysterios de $N$. Santa Fee Catholica [...]. México: Herederos de la Viuda de Miguel de Ribera Calderõ. Facsimile digital: $<$ http://www.archive.org/details/artedelalenguame00avil>

[BERTONIO, Ludovico Bertonio; DEL CANTO, Francisco; TOMÁS, Domingo de Santo; HOLGUÍN, Diego González; RUBIO, Diego de Torres; BÁRCENA, Alfonso;].1603. Arte y vocabulario en la lengua general del Peru, llamada Quichua, y en la lengua Española [...]. [Seville]: Clemente Hidalgo. Facsimile digital: <http://www.archive.org/details/ arteyvocabulario00barc>

GARRIGA, Antonio. 1713. Instruccion practica para ordenar santamente la vida [...]. Loreto. Facsimile digital: <https://archive.org/details/instruccionpract00garr >

MONTOYA, Antonio Ruiz de. 1640. Catecismo de la lengua guarani [...]. Madrid: Diego Diaz de la Carrera. Facsimile digital: <http://archive.org/details/catecismodelalen00ruiz> 
RESTIVO, Paulo. 1722. Vocabulario de la lengua guarani [...]. Santa Maria la Mayor. Facsimile digital: <https://archive.org/details/vocabulariodelal00ruiz>

RESTIVO, Paulo. 1724. Arte de la lengua guarani [...]. Santa Maria La Mayor. Facsimile digital: $<$ https://www.archive.org/details/artedelalenguagu00ruiz>

YAPUGUAI, Nicolas. 1724. Explicacion de el catechismo en lengua guarani [...]. Santa Maria la Mayor. Facsimile digital: <https://www.archive.org/details/explicaciondeelc00yapu>

YAPUGUAI, Nicolas. 1727. Sermones y exemplos en lengua guarani [...]. São Francisco Xavier. Facsimile digital: <https://www.archive.org/details/sermonesyexemplo00yapu>

\section{MANUSCRITOS}

ANÔNIMO. 16--. Ordo baptismi parvulorum [...].

MONTOYA, Antonio Juiz de. 16--. Catecismo de la lengua guarani [...]. Facsimile digital: <http:// www.brasiliana.usp.br/bbd/handle/1918/01638900>

\section{MANUSCRITOS — FACSIMILES DIGITAIS}

ANÔNIMO. 16--. Ordo baptismi parvulorum [...].

\section{REFERÊNCIAS BIBLIOGRÁFICAS}

ADONE, Agnolin. 2007. Jesuítas e selvagens - a negociação da fé no encontro catequético-ritual americano-tupi (séc. XVI-XVII). São Paulo: Humanitas Editorial.

ALFARO, Consuelo. 2001. As políticas lingüísticas e as línguas ameríndias. Em Liames - línguas indígenas americanas, $\mathrm{n}$ 1, pp 31-41. Campinas: Universidade Estadual de Campinas, Instituto de Estudos da Linguagem.

BAILEY, Gauvin Alexander. (2001). Art on the jesuit missions in Asia and latin America, 15421773. Toronto: University of Toronto Press.

BHABHA, Homi K. (1998 [1994]). O local da cultura. Belo Horizonte: Editora da UFMG.

BUARQUE DE HOLANDA, Sérgio. (2006 [1936]). Raízes do Brasil. São Paulo: Companhia das Letras.

BUARQUE DE HOLANDA, Sérgio. (2008 [1956]). Caminhos e fronteiras. São Paulo: Companhia das Letras.

BAINES, Phil e HASLAM, Andrew. (2005) Type \& typography. Nova Iorque: Waston-Guptill Publications.

BARAGER, Joseph R. (1959). The Historiography of the Río de la Plata Area Since 1830. Em The Hispanic American Historical Review, vol 39, n 4, pp 588-642. Duke University Press. $<$ http://www.jstor.org/stable/2510383>, acessado em 30/4/2010.

BRINGHURST, Robert. (2005 [1992]). Elementos do estilo tipográfico. São Paulo: Cosac Naify.

BOUZA, Fernando. (2001). Corre manuscrito - una historia cultural del siglo de oro. Madrid: Marcial Pons.

CAPISTRANO DE ABREU, João. 1914. Rã-txa hu-ni-ku-ĩ - a língua dos caxinauás do rio Ibuaçú, affluente do Murú (Prefeitura de Tarauacá). Rio de Janeiro: Typografia Leuzinger. <http:// www.brasiliana.usp.br/bbd/handle/1918/00158200>, acessado em 2013.

CARNEIRO DA CUNHA, Manuela (Org.). (1992). História dos índios no Brasil. São Paulo: Companhia das Letras. 
CELESTINO DE ALMEIDA, Maria Regina. (2003). Metamorfoses indígenas - identidade e cultura nas aldeias coloniais do Rio de Janeiro. Rio de Janeiro: Arquivo Nacional.

CHRISTINO, Beatriz. 2007. Os vaivéns da rede (internacional) de Capistrano de Abreu. Em Revista do IEB, n 45, pp 37-62. São Paulo: Instituto de Estudos Brasileiros, Universidade de São Paulo.

CLASTRES, Pierre. (1988). A sociedade contra o estado. Rio de Janeiro: Francisco Alves.

CLASTRES, Helène. (1978). Terra sem mal. São Paulo: Brasiliense.

COULMAS, Florian. (2003 [2002]). History of writing. Em Writing systems - an introduction to their linguistic analysis, pp 190-209. Cambridge, New York, Melbourne, Madrid, Cape Town, Singapore, São Paulo: Cambridge University Press.

DAHER, Andréa. 1997. Escrita e conversão: a gramática tupi e os catecismos bilíngües. Em Revista brasileira de educação, n 8, pp 31-43.

DINIZ, Kollontai. 2007. Notas sobre tipografia para línguas indígenas do Brasil. Em InfoDesignrevista brasileira de design da informação, vol 4, n 1, pp 40-50.

FABIAN, Johannes. (1983). Time and the other - how anthropology makes its object. New York, Columbia University Press.

FEBVRE, Lucien; MARTIN, Henri-Jean. (1992 [1958]). O aparecimento do livro. São Paulo: Unesp.

FERNANDES, Florestan. (1970 [1952]). A função social da guerra na sociedade tupinambá. São Paulo: Pioneira e Edusp.

FURLONG, Guillermo. 1953a. La imprenta en las Reducciones del Paraguay 1700-1727. Em Historia y bibliografia de las primeiras imprentas rio-platenses, tomo I, pp 46-100. Buenos Aires: Editorial Guarania.

FURLONG, Guillermo. 1953b. El escritor guarani Nicolas Yapuguay. Em Sermones y exemplos en lengua guarani - edicion facsimilar, pp I-IX. Buenos Aires: Guarania.

FURLONG, Guillermo (1962). Misiones y sus pueblos de guaranies. Bueno Aires: Imprenta Balmes.

FURLONG, Guillermo. (1984 [1933]). Los jesuitas y la cultura rioplatense. 3 ed. Buenos Aires: Ediciones Universidad del Salvador.

GARONE, Marina. 2009. História da tipografia colonial para línguas indígenas. Tese de doutorado não publicada. Instituto de Investigações Estéticas, Universidade Nacional Autónoma de México.
GRAÑÉN PORRÚA, María Isabel. 2010. Los grabados en la obra de Juan Pablos - primer impressor de la Nueva España: 1539-1560. México: Fondo de Cultura Económica.

GRUZINSKI, Serge. (1993). The Conquest of Mexico. Cambridge: Trans Eileen Corrigan.

GRUZINSKI, Serge. 1995. Images and cultural mestizaje in colonial Mexico. Em Poetics today, vol 16, n 1, pp 53-77. <http://www.jstor.org/stable/1773223>, acessado em 4/12/2009.

GRUZINSKI, Serge. (1991). La colonización de lo imaginario - sociedades indígenas y occidentalización en el México español, siglos XVI-XVIII. México: Fondo de Cultura Económica.

HILL, Jonathan. 1992. Constested Past and the Practice of Anthropology: Overview. Em American Anthropology, vol 94, n 4, pp 809-815. <http://onlinelibrary.wiley.com/doi/10.1525/ aa.1992.94.4.02a00020/pdf>, acessado em 2013.

JARQUE, Francisco. (1900 [1661]). Ruiz Montoya en Indias (1608-1652). Volumen Primero. Em Colección de libros raros y curiosos que tratan de América. Tomo XVI. Victoriano Suárez: Madrid. Biblioteca Nacional de España. <http://bibliotecadigitalhispanica.bne.es:80/ webclient/DeliveryManager?pid=2680535\&custom_att_2=simple_viewer $>$, acessado em abril de 2014.

JOHNSON, Julie G. 1988. The book in the Americas - the role of books and printing in the development of culture and society in colonial America. Catálogo de exposição. Vermont, Meriden: Meriden-Stinehour Press.

KLEINPENNING, Jan M. G. (2011 [2003]). Paraguay 1515-1870 - una geografía temática de su desarrollo. Assunção: Tiempo de Historia.

LUGON, Clovis. (1977 [1949]). A República "comunista" cristã dos guaranis: 1610-1768. Rio de janeiro: Paz e Terra.

LÉVI-STRAUS, Claude. (1996 [1955]). Tristes trópricos. São Paulo: Companhia das Letras.

McKEE, Stuart. 2010. How print culture came to be indigenous. Em Visible language 44, n 2, pp 161-186. Hong Kong: Visible Language.

MELIÀ, Bartomeu. (1992). La lengua guaraní del Paraguay - historia, sociedad y literatura. Madrid: MAPFRE.

MELIÀ, Bartomeu. 2002. A modo de introducción. Em Vocabulario de la lengua guarani [Antonio Ruiz de Montoya, 1640 - edição facsimilar], pp V-XIX. Assunção: CEPAG, Litocolor.

MELIÀ, Bartomeu. 2010. Passado, presente y futuro de la lengua guaraní. Assunção: CEADUC, CPI, ISEHF, Ediciones Montoya. 
MENDEZ, Sigmund. 2006. Del Barroco como el ocaso de la concepción alegórica del mundo. Em Andamios, vol 2, n 4, pp 147-180. <http://www.scielo.org.mx/scielo.php?script=sci_ arttext\&pid=S1870-00632006000100006\&lng=es\&nrm=iso $>$, acessado em 25/12/2010.

MÉTRAUX, Alfred. (1979). A religião dos tupinambás. São Paulo: Companhia Editora Nacional.

MONTEIRO, John Manuel. (2001). Tupis, tapuias e historiadores - estudos de história indígena e indigenismo. Campinas: Unicamp, Tese de Livre Docência.

MONTEIRO, John Manuel. (1994). Negros da terra - indios e bandeirantes nas origens de São Paulo. São Paulo: Companhia das Letras.

NEUMANN, Eduardo. 2005. Práticas letradas guarani: produção e usos da escrita indígena (séculos XVII e XVIII). Rio de Janeiro. Tese de doutorado não publicada. Programa de Pósgraduação em História Social, Universidade Federal do Rio de Janeiro.

NEUMANN, Eduardo. 2009. "De letra de índios”: cultura escrita e memória indígena nas reduções guaranis do Paraguai. Em Varia História, vol 25, n 41. <http://www.scielo.br/ scielo.php?script=sci_arttext\&pid=S0104-87752009000100009\&lng=en\&nrm=iso $>$, acessado em 16/3/2010.

NIMUENDAJU, Curt. (1981). Mapa etno-histórico do Brasil e regiões adjacentes.

O'MALLEY, John. The society of jesus. Em A companion to the reformation world [R. Po-chia Hsia (ed)], pp 223-236. Malden: Blackwell Publishing.

PÄRSSINEN, Martti. (2003). When did the guarani expansion toward the Andean foothills begin? Em Western Amazonia - Amazônia Ocidental [Pärssinen e Korpisaari (ed)], pp 73-95. Helsinque: Renvall Institute for Área and Cultural Studies.

PÉCORA, Alcir (2003). Antônio Vieira, sermões. Tomo I, pp 417-440. São Paulo: Hedra.

PÉREZ, Julio Calvo. (1997). La gramática aimara de Bertonio (1603) y la escuela de Juli. Em La descripción de las lenguas amerindias em la época colonial [Zimmermann, Klaus (ed)], pp 321-338. Frankfurt e Main: Vervuert. Madrid: Iberoamericana.

PIMENTA, João Paulo. 2006. Nas origens da imprensa luso-americana: o periodismo da província cisplatina (1821-1822). Em História e imprensa - representações culturais e práticas de poder [Neves, Lúcia; Morel, Marco; Ferreira, Tania (org)], pp 19-36. Rio de Janeiro: DPeA, Faperj.

PLA, Josefina. 1973. Los talleres misioneros (1609-1767). Su Organización y Funcionamiento. Em Revista de Historia de América, n 75-76, pp 9-56. <http://www.jstor.org/stable/20139101>, acessado em 16/9/2010.

PLA, Josefina. 1975. El Barroco hispanoguaraní. Assunção: Centenario.
POMPA, Cristina. 2003. Religião como tradução - missionários, Tupi e Tapuia no Brasil Colonial. Bauru: Edusc.

PUNTONI, Pedro. 2002. A guerra dos bárbaros - povos indígenas e a colonização do sertão nordeste do Brasil, 1650-1720. São Paulo: Fapesp, Hucitec, Edusp.

QUARLERI, Lía. 2009. Rebelión y guerra en las fronteras del Plata - guaranies, jesuitas e imperios coloniales. Buenos Aires: Fondo de Cultura Económica.

RODRIGUES, Aryon. (1993). Línguas brasileiras - 500 anos de descobertas e perdas. Em Ciência hoje, 16 (95).

RODRIGUES, Aryon. 2000. Panorama das línguas indígenas da Amazônia. Em As línguas amazônicas hoje [Queixalos \& Renault-Lescure (org.)], pp 15-28. São Paulo: Instituto Socioambiental.

SAID, Edward W. (2007 [1978]). Orientalismo - o Oriente como invenção do Ocidente. São Paulo: Companhia das Letras.

SAHLINS, Marshall. (1990). Ilhas de História. Rio de Janeiro: Zahar.

SALINAS, María Laura. 2011. Vida y trabajo en la misión - jesuitas y franciscanos en las misiones del Paraguay en perspectiva comparada: siglo XVII. Em Fronteiras e identidades - encontros e desencontros entre povos indígenas e missões religiosas [Granciela Chamorro; Thiago Cavalcante; Carlos Gonçalves (org)], pp 223-246. São Bernardo do Campo: Nhanduti Editora.

STERN, Steve J. (1987). Resistance, rebellion and consciousness in the Andean peasant world, 18th to 20th centuries. Madison: The University of Wisconsin Press.

SUSNIK, Branislava. (1980). Los aborígenes del Paraguai, II: Etnohistoria de los Guaranies: época colonial. Asunción: Museo Etnografico Andrés Barbedo.

TÓTH, István György. 2004. Old and new faith in Hungary, Turkish Hungary, and Transylvania. Em A companion to the reformation world [R. Po-chia Hsia (ed)], pp 375-392. Malden: Blackwell Publishing.

THOMPSON, E.P. 1981. Miséria da teoria. Rio de Janeiro: Zahar.

THOMPSON, E.P. 1987. A formação da classe operária inglesa. Vol 1. Rio de Janeiro: Paz e Terra.

TSCHICHOLD, Jan. (2007 [1975]). A forma do livro. Ensaios sobre tipografia e estética do livro. Cotia: Ateliê Editorial.

ÜÇELER, M. Antoni. 2008. The Jesuit enterprise in sixteenth and seventeenth century Japan. Em A companion to the jesuits. Cambridge: Cambridge University Press. pp 153-168. 
UPDIKE, Daniel. 1922. Printing types, their history forms and use - a study in survivals. vol 2. Cambridge: Harvard University Press.

VAINFAS, Ronaldo. (1995). A Heresia dos índios - catolicismo e rebeldia no Brasil colonial. São Paulo: Companhia das Letras.

VARNHAGEN, Francisco Adolfo. (1962). História geral do Brasil - anotada por Capistrano de Abreu e Rodolfo Garcia, ed 7, v 5. São Paulo: Companhia Melhoramentos.

VERISSIMO, Fernanda. 2011. L'impression dans les missions jésuites au Paraguay: 1705-1727. Tese de doutorado não publicada. École Doctorale D’Histoire Moderne et Contemporaine, L'Université Paris-Sorbonne.

VIVEIROS DE CASTRO, Eduardo. 1986. Araweté - os deuses canibais. Rio de Janeiro: Zahar.

VIVEIROS DE CASTRO, Eduardo. (2011[2002]). O mármore e a murta — sobre a inconstância da alma selvagem. Em A inconstância da alma selvagem - e outros ensaios de antropologia, pp 183-264. São Paulo: Cosac \& Naify.

WILDE, Guillermo. 2009. Religión y poder en las misiones de guaranies. Buenos Aires: Editorial Sb.

WOODBRLDGE, Hensley; THOMPSON Lawrence. 1976. Printing in colonial spanish America. Troy, Nova York: Whitson Publishing Company.

WROTH, Lawrence C. 1926. The origins of typefounding in north and south america. Em Ars Typographica, vol 2.

WAISMAN, Leonardo. 2011. "Musica del barroco missional": un concepto o un slogan? Em Saberes de la conversión - jesuitas, indígenas e imperios coloniales en las fronteras de la cristiandad [Wilde, Guillermo (ed)], pp 333-344. Buenos Aires: Editorial Sb.

\section{ANEXO 1 - LOCALIZAÇÃO ATUAL DOS IMPRESSOS GUARANÍTICOS SEGUNDO FERNANDA VERÍSSIMO.}

Fonte: VERÍSSIMO, Fernanda. (2011). L'impression dans les Missions Jésuites au Paraguay: 1705-1727. Tese de doutorado não publicada. École Doctorale D'Histoire Moderne et Contemporaine, L'Université Paris-Sorbonne. Anexo II, pp 318-325.

\section{[Meus comentários à lista aparecerão entre colchetes.]}

No início do nosso trabalho, a única lista que encontramos com a localização de livros impressos nas missões jesuiticas do Paraguai foi a de Josefina Pla, em seu livro "El Barroco Hispano Guaranî" 1975. Desde então, a a localização desses livros mudou muito e muitos deles, especialmente aqueles nas mãos de colecionadores particulares, foram vendidos $e$ agora estão em grandes bibliotecas públicas ou universitárias. Nem sempre fomos capazes de encontrar o mesmo número de cópias listados por Josefina Pla, e, nestes casos, indicamos em nota de rodapé. Nós também incluímos aqui os livros e panfletos que certamente foram impressos, mas que são conhecidos apenas pela correspondência dos jesuitas, e cujos exemplares jamais foram encontrados.

(VERÍssImo, 2011:318 - tradução minha ${ }^{1}$ )

\section{MARTIROLOGIO ROMANO}

Redução de Loreto, 1700 [Segundo Furlong há uma segunda edição de 1709, impressa também em Loreto]

Sem exemplares conhecidos.

\footnotetext{
1 "Au début de notre travail, la seule liste avec la localisation de livres imprimés dans les missions jésuites du Paraguay que nous avons trouvée était celle de Josefina Pla, dans son livre «El Barroco Hispano Guarani”, de 1975. Depuis, lemplacement de ces livres a beaucoup change et plusieurs dentre eux, surtout ceux qui étaient entre les mains des collectionneurs privés, ont été vendus et se trouvent maintenant dans les grandes bibliothèques publiques ou universitaires. Parfois, nous nétions pas en mesure de trouver le même nombre dexemplaires listés par Josefina Pla et, dans ces cas, nous le soulignons en note de pied de page. Nous incluons également ici les livres et opuscules qui ont certainement été imprimés, mais qui ne sont connus que par la correspondance jésuite et
dont aucun exemplaire ná jamais été retrouvé." (VERÍSSIMO, 2011:318)
} 
2.

\section{FLOS SANCTORUM}

Sem exemplares conhecidos.

3 .

DE LA DIFERENCIA ENTRE LO TEMPORAL Y LO ETERNO, Crisol de desengaños, con la memoria de la eternidad, postrimerias humanas y principales misterios divinos por el $\mathrm{P}$. Juan Eusebio Nierenberg, de la Compañia de Jesús, y traducido en lengua guarani por el Padre Joseph Serrano, de la misma Compañia. Impreso en las Doctrinas, año de 1705.

Redução de Loreto, 1705

Coleção de Horacio Porcel (Buenos Aires, Argentina)

Biblioteca Enrique Peña (Lujan, Argentina)

$4 \cdot$

INSTRUCCION PRACTICA PARA Ordenar Santamente la vida; que ofrece El P. Antonio Garriga de la Compañia de Iesus. Como brebe memorial, y recuerdo à los que hazen los exercicios espirituales de S. Ignacio de loyola Fundador de la misma Compañia. En Loreto, con licencia de los Superiores en la Imprenta de la Compañia Año de 1713

Redução de Loreto, 1713

John Carter Brown Library (Providence, EUA)

5.

\section{PANFLETOS VARIADOS}

Sem exemplares conhecidos.

Algunos trataditos en castellano, Padre Jose Serrano.

Algunos trataditos en guaraní, editados pelo Padre Jose Serrano.

Efemérides, editados pelo Padre Buenaventura Suárez.

Diarios manuales, editados pelo Padre Buenaventura Suárez.

Calendarios, editados pelo Padre Buenaventura Suárez.

Tablas astronómicas, editados pelo Padre Buenaventura Suárez.

Estaciones del año, editados pelo Padre Buenaventura Suárez.

Mudanzas de los tiempos, editados pelo Padre Buenaventura Suárez.

[Furlong lista também: Cursos de los planetas, editados pelo Buenaventura Suárez.]

\section{[BREVE TRATADO DE MEDICINA]}

Do Padre Segismundo Aperger [Redução de Loreto, 1720]

Sem exemplares conhecidos.

MANUALE AD USUM PATRUM SOCIETATIS JESU QUI IN REDUCTIONIBUS

PARAQUARIAE VERSANTUR. Laureti Typis P. P. Societatis Jesu. 1721.

Redução de Loreto, 1721

John Carter Brown Library (Providence, EUA)

Fondo Antiguo de la Compañia de Jesus na Argentina (Laboratório de Conservação Nicolás

Yapuguay /Colegio del Salvador) (Buenos Aires, Argentina)

Coleção particular em Buenos Aires (Buenos Aires, Argentina) (não confirmado)

Biblioteca Nacional da Espanha (Madrid, Espanha)

University of Michigan, William L. Clements Library (Ann Arbor, EUA)

VOCAbUlario De la LENGUA GUARANi COMPUESTO Por el Padre Antonio Ruiz de la Compañia de IESUS Revisto, y Augmentado Por otro Religioso de la misma Compañia EN EL PUEBLO DE S. MARIA LA MAYOR. El Año de MDCCXXII.

Redução de Santa Maria La Mayor, 1722

John Carter Brown Library (Providence, EUA)

Biblioteca Nacional de la Republica Argentina (Buenos Aires)

British Library (Londres, Reino Unido)

Biblioteca de la Universita de Granada (Granada, Espanha)

Coleção Horacio Porcel (Buenos Aires, Argentina)

Fundação Biblioteca Nacional (Rio de Janeiro, Brasil)

Staatsbibliothekzu Berlin (Berlin, Alemanha)

ARTE DE LA LENGUA GUARANI POR EL PADRE ANTONIO RUIZ DE Montoya DE LA COMPAÑIA DE JESUS Con los Escolios Anotaciones y Apendices DEL P. PAULO RESTIVO de la misma Compañia, Sacados de los papeles DEL P. SIMON BANDINI y de otros. En el Pueblo de S. MARIA La Mayor. El AÑO de el Señor MDCCXXIV.

Redução de Santa Maria La Mayor, 1724

John Carter Brown Library (Providence, EUA)

Biblioteca Nacional de Chile (Santiago, Chile) 
Texas University - The Nettie Lee Benson Latin American Collection (Austin, EUA) Indiana University (Bloomington, EUA)

Bibliothèque Nationale de France (Paris)

British Library (Londres, Reino Unido)

Fundação Biblioteca Nacional (Rio de Janeiro, Brasil)

Coleção Horacio Porcel (Buenos Aires, Argentina)

Fondo Antiguo de la Compañia de Jesus na Argentina (Laboratório de Conservação Nicolás

Yapuguay/Colegio del Salvador, à Buenos Aires) (Buenos Aires, Argentina)

Staatsbibliothek zu Berlin (Berlin, Alemanha)

The Oliveira Lima Library (The Catholic University of America) (Washington DC, EUA)

Biblioteca de la Pontifícia Università Gregoriana (Roma, Itália)

Biblioteca Brasiliana Guita e José Mindlin (São Paulo, Brasil)

10.

EXPLICACION DE EL CATECHISMO EN LENGUA GUARANI POR NICOLAS YAPUGUA CON DIRECTIONDEL P. PAULO RESTIVO DE LA COMPAÑIA DE JESUS En el Pueblo de S. MARIA La Mayor. Año de MDCCXXIV

Redução de Santa Maria La Mayor, 1724

John Carter Brown Library (Providence, EUA)

Fundação Biblioteca Nacional (Rio de Janeiro, Brasil)

Collection Porcel (Buenos Aires, Argentina)

Biblioteca Brasiliana Guita e José Mindlin (São Paulo, Brasil)

British Library (Londres, Reino Unido)

Fondo Antiguo de la Compañia de Jesus na Argentina (Laboratório de Conservação Nicolás Yapuguay/Colegio del Salvador) (Buenos Aires, Argentina)

Bibliothèque Sainte Geneviève (Paris, France)

Bodleian Library (Oxford, Reino Unido)

Katholieke Universiteit Leuven, Centrale Bibliotheek (Louvain, Belgica)

11.

SERMONES Y EXEMPLOS EN LENGUA GUARANI Por Nicolas Yapuguay Con direction DE VN RELIGIOSO DE LA COMPAÑIA DE IESUS. En el Pueblo de S. Francisco Xavier Año de MDCCXXVII.

Redução de São Francisco Xavier, 1727

John Carter Brown Library (Providence, EUA)

Collection Horacio Porcel (Buenos Aires, Argentine)

Fondo Antiguo de la Compañia de Jesus en Argentine (Laboratoire de Conservation Nicolás

Yapuguay/Colegio del Salvador, à Buenos Aires)
Coleção particular em Buenos Aires (Buenos Aires, Argentina) (não confirmado)

CARTA QUE EL SEÑOR DOCTOR JOSE DE ANTEQUERA Y CASTRO CABALLERO DE LA ORDEN DE ALCANTARA PROTECTOR GRAL DE INDIOS EN LA REAL AUDIENCIA DEL PLATA Y GOBERNADOR QUE FUE DE LA PROVINCIA DEL PARAGUAY? ESCRIBIO AL ILMO Y RMO SEÑOR OBISPO DEL PARAGUAY D FR. IOSEPH PALOZ (Typis Missionum Paraquariae in oppido S. Xavieri anno 1727).

Redução de São Francisco Xavier, 1727

British Library (Londres, Reino Unido)

LUNARIO DE UN SIGLO que comienza que comenza por enero del año de 1740., y acaba en diziembre del año de 1841. en que se comprehenden ciento y un años cumplidos. Contiene los aspectos principales de sol, y luna, esto es, las conjunciones, oposiciones, y quartos de la luna con el sol, segun sus movimientos verdaderos: y la noticia de los eclipses de ambos luminares, que serán visibles por todo el siglo en estas missiones de la Compañia de Jesus en la provincia del Paraguay. : Regulada, y aligada la hora de los aspectos, y eclipses al meridiano del pueblo de los esclarecidos martyres San Cosme, y San Damian, y estendido su uso à otros meridianos por medio de la tabla de las diferencias meridianas, que se pone al principio de el lunario. : Danse al fin de el reglas faciles, para que qualquiera, sin mathematica, ni arithmetica, pueda formar de estos lunarios de un siglo los de los años siguientes, desde el de 1842. hasta el de 1903

Sobre esta obra, Fernanda Veríssimo diz que, "Este livro pode ter sido impresso nas missões, mas os únicos exemplares localizáveis foram impressos na Europa e, mais tarde, no Equador." (veríssimo, 2011:325 — tradução minha²)] 
ANEXO 2 - IMPRESSOS E MANUSCRITOS GUARANÍTICOS: EXEMPLARES QUE ANALISEI, EM ORDEM CRONOLÓGICA, COM A LOCALIZAÇÃO ONLINE (QUANDO CABÍVEL).

IMPRESSOS GUARANÍTICOS

INSTRUCCION PRACTICA PARA Ordenar Santamente la vida; que ofrece El P. Antonio Garriga de la Compañia de Iesus. Como brebe memorial, y recuerdo à los que hazen los exercicios espirituales de S. Ignacio de loyola Fundador de la misma Compañia. En Loreto, con licencia de los Superiores en la Imprenta de la Compañia Año de 1713

Redução de Loreto, 1713

John Carter Brown Library (Providence, EUA)

Facsimile digital: https://archive.org/details/instruccionpractoogarr (último acesso em $5.3 .2014)$

MANUALE AD USUM PATRUM SOCIETATIS JESU QUI IN REDUCTIONIBUS PARAQUARIAE VERSANTUR. Laureti Typis P. P. Societatis Jesu. 1721.

Redução de Loreto, 1721

John Carter Brown Library (Providence, EUA)

Facsimile digital: https://archive.org/details/manualeadusumpatoocath (último acesso em

$5.3 .2014)$

VOCABUlario De la LENGUA GUARANI COMPUESTO Por el Padre Antonio Ruiz de la Compañia de IESUS Revisto, y Augmentado Por otro Religioso de la misma Compañia EN EL PUEBLO DE S. MARIA LA MAYOR. El Año de MDCCXXII.

Redução de Santa Maria La Mayor, 1722

John Carter Brown Library (Providence, EUA) 
Facsimile digital: https://archive.org/details/vocabulariodelalooruiz (último acesso em $5.3 .2014)$

4.

ARTE DE LA LENGUA GUARANI POR EL PADRE ANTONIO RUIZ DE Montoya DE LA COMPAÑIA DE JESUS Con los Escolios Anotaciones y Apendices DEL P. PAULO RESTIVO de la misma Compañia, Sacados de los papeles DEL P. SIMON BANDINI y de otros. En el Pueblo de S. MARIA La Mayor. El AÑO de el Señor MDCCXXIV.

Redução de Santa Maria La Mayor, 1724

Biblioteca Brasiliana Guita e José Mindlin (São Paulo, Brasil)

Facsimile digital: http://www.brasiliana.usp.br/bbd/handle/1918/0230960o (último acesso em $5 \cdot 3.2014)$

John Carter Brown Library (Providence, EUA)

Facsimile digital: https://www.archive.org/details/artedelalenguaguooruiz (último acesso em $5.3 .2014)$

5.

EXPLICACION DE EL CATECHISMO EN LENGUA GUARANI POR NICOLAS YAPUGUAI CON DIRECTIONDEL P. PAULO RESTIVO DE LA COMPAÑIA DE JESUS En el Pueblo de S. MARIA La Mayor. Año de MDCCXXIV

Redução de Santa Maria La Mayor, 1724

Biblioteca Brasiliana Guita e José Mindlin (São Paulo, Brasil)

Facsimile digital: http://www.brasiliana.usp.br/bbd/handle/1918/0179980o (último acesso em 5.3.2014)

John Carter Brown Library (Providence, EUA)

Facsimile digital: https://www.archive.org/details/explicaciondeelcooyapu (último acesso em $5.3 .2014)$

SERMONES Y EXEMPLOS EN LENGUA GUARANI Por Nicolas Yapuguay Con direction DE VN RELIGIOSO DE LA COMPAÑIA DE IESUS. En el Pueblo de S. Francisco Xavier Año de MDCCXXVII.

Redução de São Francisco Xavier, 1727

John Carter Brown Library (Providence, EUA)
Facsimile digital: https://www.archive.org/details/sermonesyexemploooyapu (último acesso em 5.3.2014)

MANUSCRITOS GUARANÍTICOS

CATECISMO DE LA LENGVA GVARANI , COMPVESTO por el Padre

Antonio Ruyz de la Compañia de Iesus. Dedicado a la purissima Virgen

MARIA. Con cebida sin mancha de peca-do original. CON LICENCIA En

Madrid, Por Diego Diaz de la Carrera, Año M. DC. XXXX. [16--]

Biblioteca Brasiliana Guita e José Mindlin (São Paulo, Brasil)

Facsimile digital: http://www.brasiliana.usp.br/bbd/handle/1918/01638900 (último acesso em $5.3 .2014)$

ORDOBAPTIS MI PARVVLORUM . Preguntas enla Lengua Guarani para

Baptizar Quid petis \&c. [16--]

Biblioteca Brasiliana Guita e José Mindlin (São Paulo, Brasil)

EDVCACION CHRISTIANA: Y Buena Criança delos Niños Guaranis: Provechosa para todos estados. QUE CONTIENE VARIOS EXERCICIOS DE DEVOCION PROVECHOSOS Para alcançar Perseverancia final y una buena Muerte. Compuestos em Lengua Guarani Por vn Padre de la Compañia de IESUS. Deseoso del bien de las Almas Dedicala àla Comun vtilidad. Año de 1713.

John Carter Brown Library (Providence, EUA)

Facsimile digital: http://www.archive.org/details/edvcacionchristiooruiz (último acesso em 5.3 .2014 
ANEXO 3 - CONJUNTO DE LETRAS GRANDES DOS IMPRESSOS GUARANÍTICOS APRESENTADAS NESTA DISSERTAÇÃO. EM ORDEM ALFABÉTICA. 


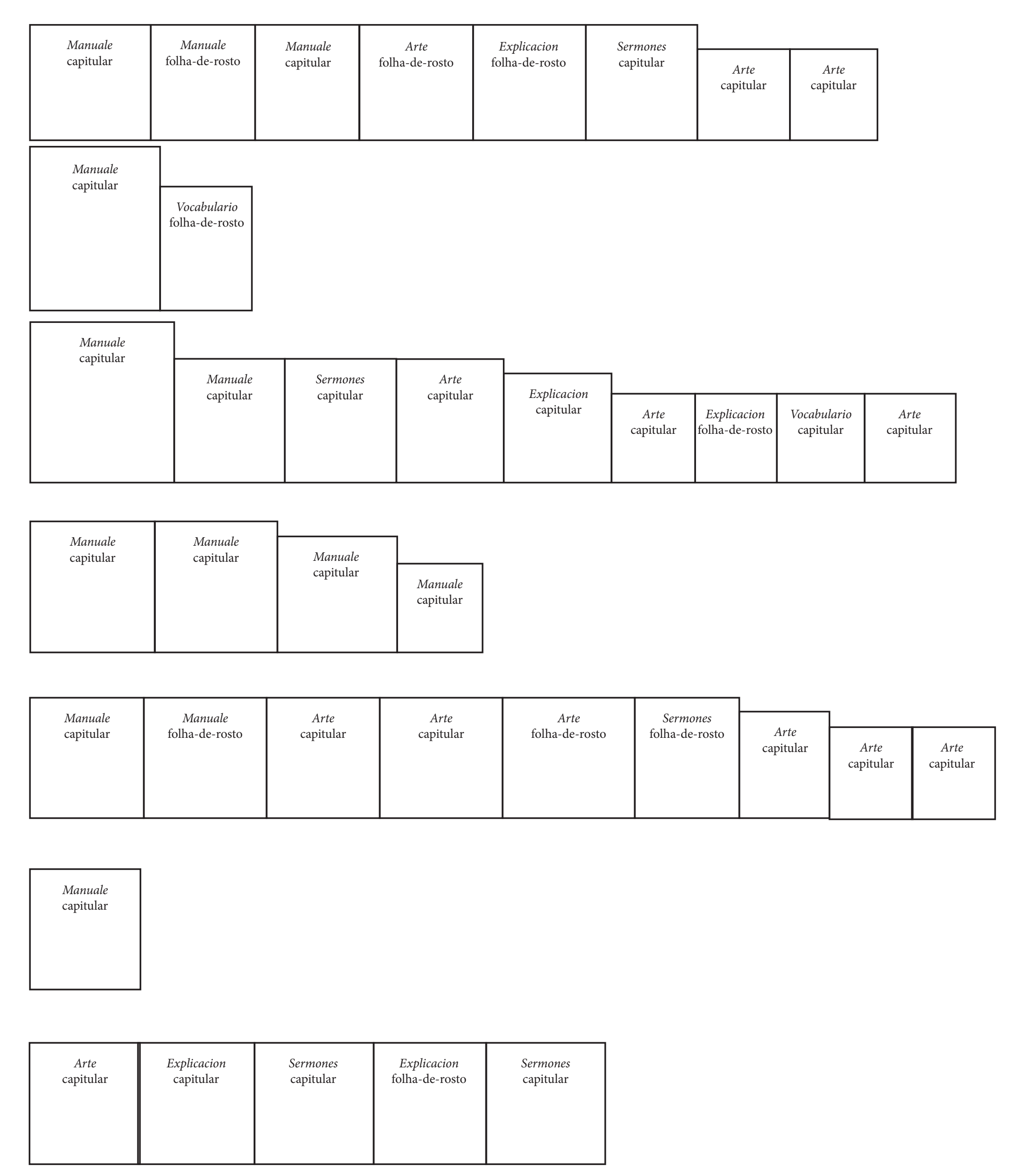

\section{AAAAAAAA $\mathrm{BB}$ CecCaccec DDDD EEEEEEEEE F $\mathrm{HHHHH}$}




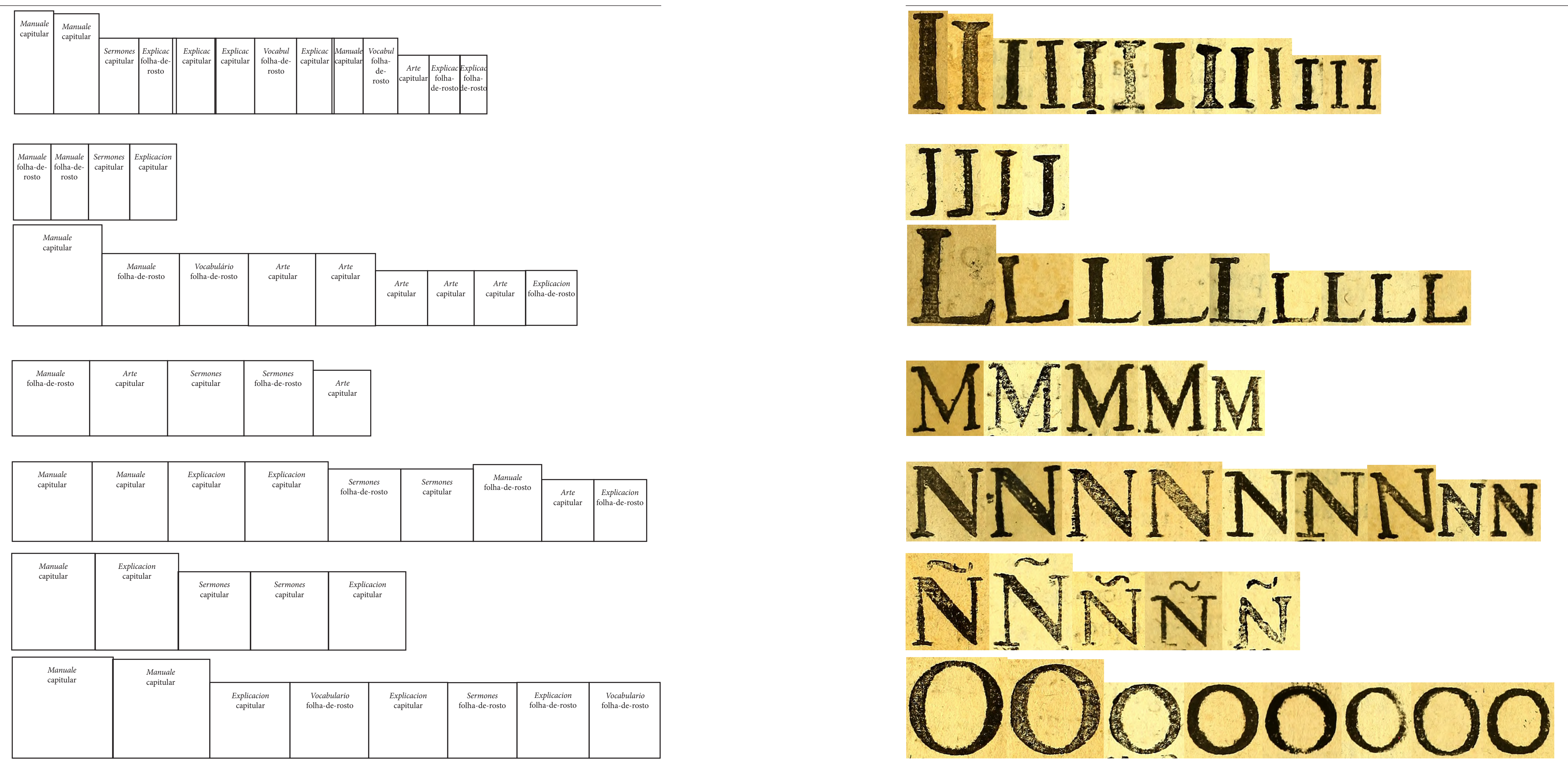




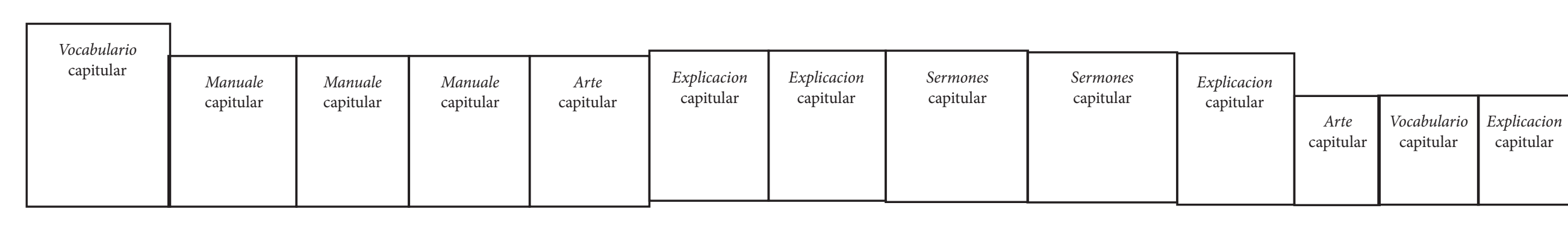

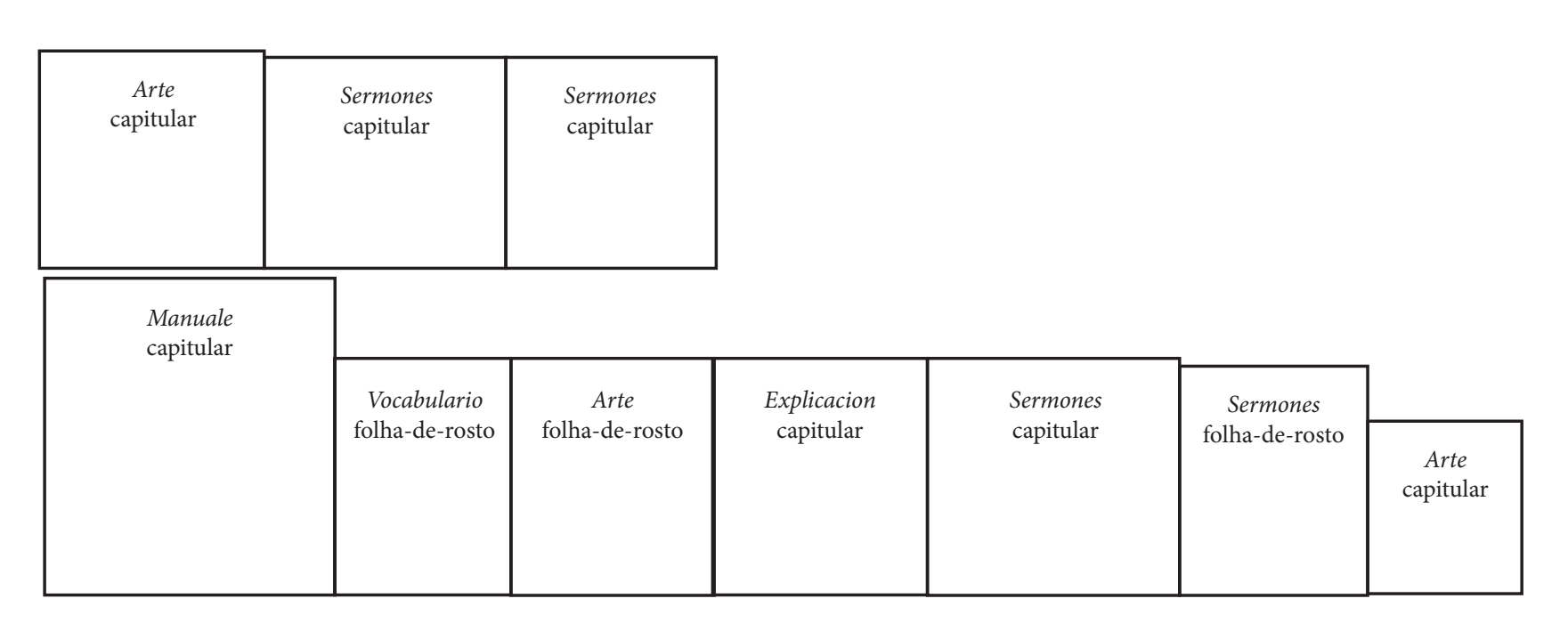

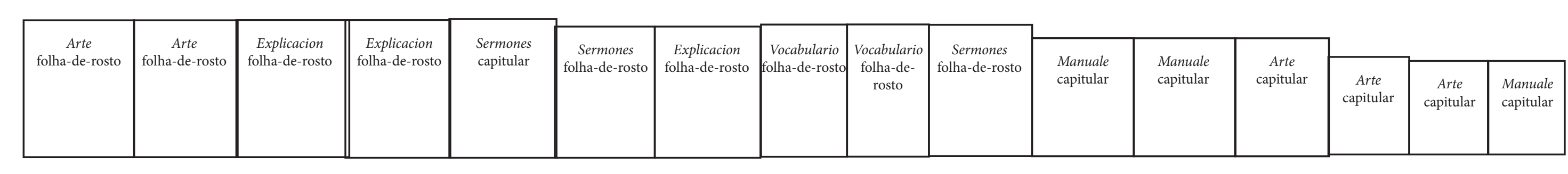

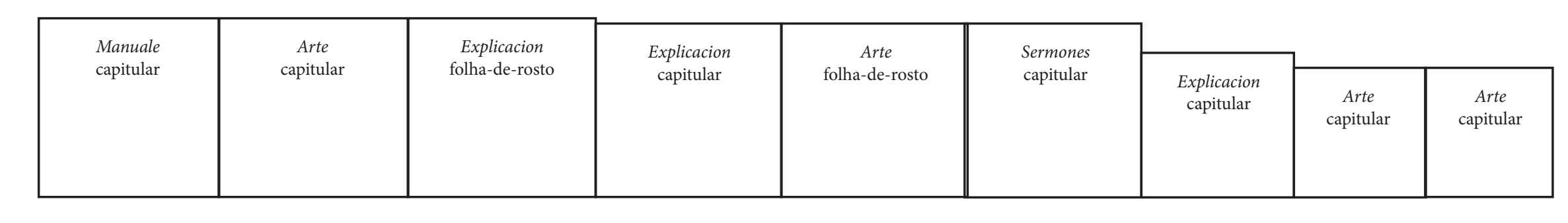

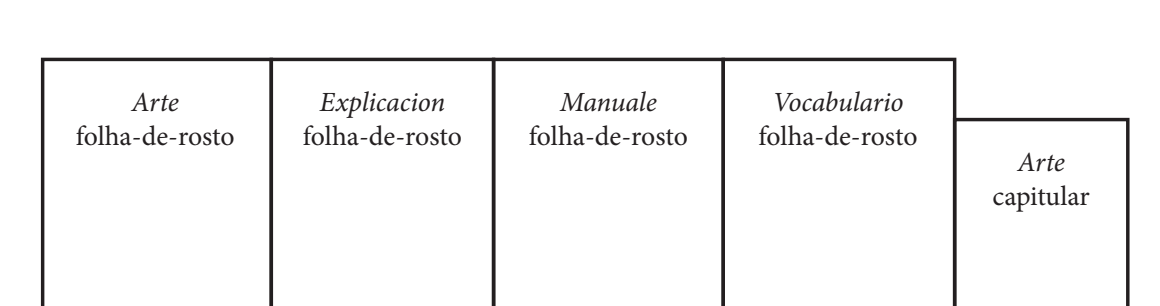

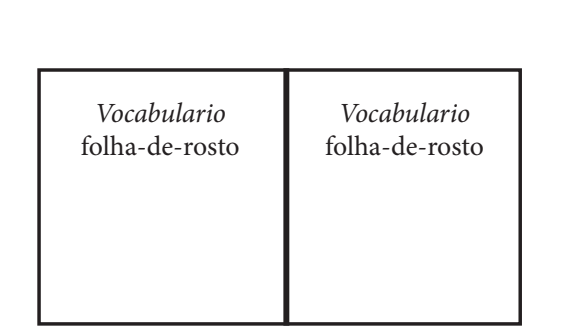

PPPPPPPPPPPPP

QQQ.

RRRRRRR

SSSSSSSSSSSSSSSS

TTTTTTTTT

UUUUU

VV 


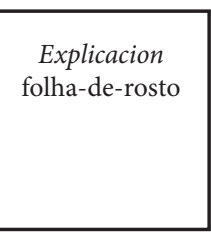

\begin{tabular}{|c|c|c||c|}
\hline $\begin{array}{c}\text { Explicacion } \\
\text { capitular }\end{array}$ & $\begin{array}{c}\text { Explicacion } \\
\text { capitular }\end{array}$ & $\begin{array}{c}\text { Sermones } \\
\text { capitular }\end{array}$ & $\begin{array}{c}\text { Sermones } \\
\text { follha-de-rosto }\end{array}$ \\
\hline
\end{tabular}

\begin{tabular}{|c||c||c|c|c|}
\hline $\begin{array}{c}\text { Sermones } \\
\text { capitular }\end{array}$ & $\begin{array}{l}\text { Sermones } \\
\text { capitular }\end{array}$ & $\begin{array}{l}\text { Sermones } \\
\text { capitular }\end{array}$ & $\begin{array}{c}\text { Explicacion } \\
\text { capitular }\end{array}$ & $\begin{array}{c}\text { Explicacion } \\
\text { capitular }\end{array}$ \\
& & & & \\
\hline
\end{tabular}

Explicacion
capitular
X

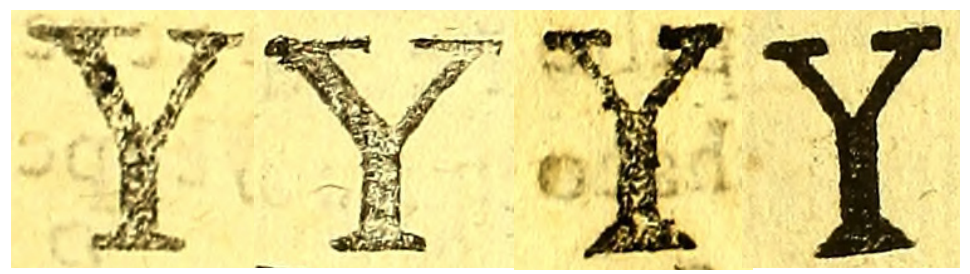

$\check{Y} \breve{Y} \bar{Y} \bar{Y}$

$\mathrm{Z}$ 